\title{
Competing fictions: Eighteenth-century domestic novels, women writers, and the trope of female rivalry
}

Elizabeth Johnston

West Virginia University

Follow this and additional works at: https://researchrepository.wvu.edu/etd

\section{Recommended Citation}

Johnston, Elizabeth, "Competing fictions: Eighteenth-century domestic novels, women writers, and the trope of female rivalry" (2005). Graduate Theses, Dissertations, and Problem Reports. 2313.

https://researchrepository.wvu.edu/etd/2313

This Dissertation is protected by copyright and/or related rights. It has been brought to you by the The Research Repository @ WVU with permission from the rights-holder(s). You are free to use this Dissertation in any way that is permitted by the copyright and related rights legislation that applies to your use. For other uses you must obtain permission from the rights-holder(s) directly, unless additional rights are indicated by a Creative Commons license in the record and/ or on the work itself. This Dissertation has been accepted for inclusion in WVU Graduate Theses, Dissertations, and Problem Reports collection by an authorized administrator of The Research Repository @ WVU.

For more information, please contact researchrepository@mail.wvu.edu. 


\title{
Competing Fictions: Eighteenth-Century Domestic Novels, Women Writers, and the Trope of Female Rivalry
}

\author{
Elizabeth Johnston
}

\author{
Dissertation submitted to \\ the Eberly College of Arts and Sciences \\ at West Virginia University \\ in partial fulfillment of the requirements \\ for degree in \\ Doctor of Philosophy \\ in \\ English Literature \\ Robert Markley, Ph.D., Chair \\ Marilyn Francus, Ph.D. \\ John B. Lamb, Ph.D. \\ Adam Komisaruk, Ph.D. \\ Jonathan Burton, Ph.D. \\ Rajani Sudan, Ph.D. \\ Department of English \\ Morgantown, West Virginia \\ 2005
}

Keywords: eighteenth-century fiction, eighteenth-century literature, eighteenth-century domestic fiction, eighteenth-century conduct book fiction, feminism, female rivalry, eighteenth-century women writers, Samuel Richardson, Sarah Scott, Frances Burney, Maria Edgeworth, Luce Irigaray, Nancy Armstrong 


\section{Abstract \\ Competing Fictions: Eighteenth-Century Domestic Novels, Women Writers, and the Trope of Female Rivalry}

\section{Elizabeth Johnston}

This dissertation focuses on mid to late eighteenth-century domestic fiction by Samuel Richardson, Sarah Scott, Frances Burney, and Maria Edgeworth, arguing that female rivalry in the novel performs a complex double function, both reinscribing domestic ideology and undermining it. I begin with the premise that Richardson's depiction of female rivalry differs significantly from those of the women writers who follow him. My chapter on Richardson's Clarissa examines his depiction of rivalry between Clarissa and all the other women of the novel, arguing that the "bad" women work to overshadow Lovelace's abuses; in other words, female rivalry effectively displaces a critique of masculine violence inherent in patriarchy. My second chapter turns to Sarah Scott's Millenium Hall, a feminist utopia which calls attention to the ways in which women are culturally constructed to view each other as rivals in a market with limited opportunities for economic advancement. Yet where one expects female rivalry, Scott's text routinely refuses to take that turn, privileging instead female ho mosocial intimacy. Burney's Cecilia also works to revise the trope of female rivalry. Whereas in Richardson's novel misreading is a marker of an essential female deficiency, in Cecilia Burney implicitly blames domestic ideology and the literary tradition by which it is propagated for women's faulty interpretative skills and, further, contrasts the intensity of female friendship with impotent, inadequate heterosexual alternatives. Maria Edgeworth's novel Belinda also emphasizes the relationships between female characters over the heterosexual narrative, even when those relationships are rivalrous. Like Burney, Edgeworth suggests these rivalries are the products of misreadings for which she faults conventional romantic ideology. In my conclusion, I discuss our inheritance as feminist scholars in academia and the ways in which we tend to replicate rivalries between feminisms and femininities, as well as between "mainstream" and "academic" women. I think we can draw connections between the divisionary impulse in the literary and critical history of eighteenth-century women's writing and the tensions today. 


\section{Dedication}

This dissertation is dedicated to my husband, Carl Silvio, for without his miraculous wellspring of love, support, and reassurance I could not have completed this project. 


\section{Acknowledgements}

Thanks to Dr. Robert Markley, whose graduate seminars in eighteenth-century fiction inspired me, and under whose careful and critical eye this project slowly took shape. Thanks also to my committee members-Marilyn Francus, Jonathon Burton, John Lamb, Adam Komisaruk, and Rajani Sudan-for their guidance and helpful advice during the writing process, as well as for the graduate seminars they taught which encouraged me to grow as a scholar. A special thanks to Marilyn Francus for the extraordinary amount of time she invested in helping me to edit the dissertation for final publication. 


\section{Table of Contents}

Introduction: The Problem of Female Rivalry.............................................................

Chapter One: "their Helping Hands": Domestic Violence and the Complicity of "Bad"

Girls in Samuel Richardson's Clarissa ......................................................47

Chapter Two: Utopic Sorority?: Female Rivalry and Revision in Sarah Scott's

Millenium Hall (1762) .......................................................................107

Chapter Three: "Secure in his own castle": Female Rivalry and Feminist Revision in

Frances Burney's Cecilia (1782)........................................................150

Chapter Four: 'Jealousies Without End or Common Sense': Domestic Ideology,

Romance, and Resistance in Maria Edgeworth's Belinda (1802)...........190

Conclusion: Women at Odds, a Continuing Struggle .....................................................236 


\section{Introduction: The Problem of Female Rivalry}

"Oh the deadly snares/That women set for women, without pity/Either to soul or honour!

...Like our own sex, we have no enemy, no enemy!"--Thomas Middleton (1613/14; 1657)

"Dear sisters, we have met the enemy and she is us." -Marianne M. Jennings (1998)

The first quotation above is from a bloody seventeenth-century tragedy which focuses on a wealthy widow who routinely betrays the women who trust her. The second excerpt can be found in an essay entitled, "Who's Harrassing Whom?," in which Jennings argues that women have exacerbated the issue of sexual harassment, muddying the court system with unwarranted complaints. Both represent a significant rhetorical tradition by which social and political conflicts are displaced onto the narrative of female rivalry. The prevalence of this tradition raises several pertinent questions: What motivates this long existing cultural preoccupation with pitting women against women? Why does the narrative of female rivalry work so well as a figure of displacement for cultural anxieties associated with gender? In what ways does female competition/rivalry differ from male rivalry? What can we say about the historical specificity of the trope of female rivalry--or of its narrative's ability to trespass historical, cultural, and ideological boundaries?

Recent studies have explored the significance of female rivalry in Greek and Biblical mythology and fairytales. ${ }^{1}$ Of course, female rivals show up most ubiquitously 
in romances. However, more than simply plot devices contrived to defer inevitable domestic bliss, female rivals often perform the regulatory work of gender ideology. Susan Ostrov Weisser says of the dynamics of female rivalry in Harlequin novels:

The covert message of the text is that love is an operation of power as an end in itself, since it pits the unworthy rival in a struggle against the underdog heroine to see who wields the greater attraction for the hero. In the marketplace of desire in these texts, power is therefore disguised as the natural reward for true womanhood, rather than displayed as the real coin of exchange for the prize of the coveted male.(275)

Female characters believe they will be empowered by adopting standards of female desirability; instead they forfeit agency, exchanging female community for a compulsory and exclusive heterosexuality. In the romance narrative, female desirability necessitates women's isolation from other women. The heroine who wins the man's love is the "real" woman; other women are present only to contrast her desirability. Her rivals, who have functioned to contain transgressive feelings she must not articulate, are ultimately rejected by the hero. Although he may have once desired the "other" women, he is shown the error of his ways; the heroine teaches him to recognize true female desirability and, thereafter, helps him to locate and tame his own wayward desire. The "other" women's exile from the hero's heart (and the story) represents the expulsion of competing desires from the narrative of female desirability. 
Ostrov-Weisser argues that the Harlequin romance, championing the allure of hearth and home, represents a backlash against the modern feminist movement. In fact, the Harlequin romance is arguably a more contemporary version in a long tradition of domestic fiction performing the same kind of ideological work. In Sisters and Rivals in British Women's Fiction, 1914-39 Diana Wallace blames the ubiquitous theme of female competition in early twentieth-century domestic fiction on anxieties about women's burgeoning work opportunities during the war. Concern that women will steal men's jobs and establish for themselves unified strength is displaced onto the narrative of female rivalry. She explains, "Focusing women's attention on the 'man shortage' and constructing other women as rivals rather than potential political allies was one way of controlling women and pushing them back into the home" (14). However, Wallace argues, women writers were strongly influenced by nascent psychoanalytic theory, specifically Freud's work on female sexuality, which she claims enabled them to problematize female rivalry and explore the tenuous bonds between women.

My dissertation responds to Wallace's call for further examination "of how the female-identified erotic triangle might be utilized by other women writers in other periods, and how this reflects women's powers, bonds and rivalries" (190). It makes sense to extend her argument back to the emergence of popular domestic fiction in the eighteenth century. The reasons for this emergence are historically complex and rooted in significant cultural and political transformations. As women writers begin to achieve literary notoriety for the first time in the eighteenth century, they challenge, as forcefully as their twentieth century counterparts, the "hitherto exclusively masculine domains such as politics, education and the professions" (Wallace 14). Fiction which celebrates 
domesticity works to assuage anxieties concerning increasing female agency by turning women's attention away from public activity to private. The implicit threat to male authorial privilege posed by women writers thus gets displaced onto same-sex rivalry. As I will argue, these rivalries written by male authors, generated by and generating female gossip, implicitly challenge women's right to tell stories. Moreover, that these fictional rivalries are usually the effect of misreadings - that is, the result of women who incorrectly judge other women's intentions_-suggests concerns about rising female literacy. These stories thus imply that a female readership may not be objective enough judges of the behavior of fictional characters - they lack the skill to responsibly employ the dialogic potential opened up by the novel.

However, more than simply relocating Wallace's argument in the eighteenthcentury, my dissertation complicates its argument. I contend that the pervasiveness of eighteenth-century stories of female rivalry results from the need to construct a version of privatized femininity conducive to the values of an emergent capitalist marketplace. The triumph of capitalism, not fully cemented until the nineteenth century, depends on the popular adoption of middle-class values in the eighteenth-century. The public actors of this rising economy, men of the middling ranks, were buoyed by the support of wives who maintain and preserve the safe haven that is their home. In fact, the eighteenthcentury's idealized "home" anchors its burgeoning middle-class economy. The trope of female rivalry participates in defining which type of woman gets to live inside and manage that home--and which other women must be exiled from it. In this respect, female rivalry in eighteenth-century fiction works to negotiate crises not only in gender ideology, but in the class ideology to which gender is so inextricably linked. A 
consideration of the ways in which female rivalry exposes conflicts in class and gender ideologies as well as their dialectic relationship necessarily complicates Wallace's analysis of twentieth-century domestic fiction.

Another significant departure of my work from Wallace's concerns the very nature of female rivalry examined. The period which separates eighteenth-century domestic fiction and fiction written during and after World War I dramatically alters the narrative of female rivalry and enables its writers to theorize female sexuality in terms unavailable to them before psychoanalytic theory. Female rivals of twentieth-century domestic fiction make explicit sexual tensions discursively inaccessible to eighteenthcentury writers. As such, narratives of female rivalry in the eighteenth-century novel are managed differently. Competition over a man, although present in eighteenth century domestic fiction, nearly always involves either an absent rival (a character only discussed, but never present in the narrative), a distant rival (a marginal character lacking subjectivity), or an imaginary rival (the result of a miscommunication).

When explicitly of a sexual nature, rivalry masks popular criticism of the marriage market, pitting woman against woman in a fight for scarce marriageable men and elusive social prestige. As convenient allegories for such critique, the relationships between sexual rivals lack complexity. Therefore, although I do examine the conditions of female sexual rivalry, I am concerned with other, more covert and complex forms of female competition—as in mother/daughter conflicts, political and class partisanship, and fights between women for the (questionably) platonic affections of other women. These fictional relationships, because they are not necessarily intended to serve as social 
allegories, more painfully reveal the pressures felt by their writers as they struggle against restrictive gender expectations.

Yet even while women writers reproduce the trope of female rivalry, they also work against it. As a genre, the novel attracts a large number of women writers. The formal qualities of the novel enable its authors to interiorize female rivalry and to challenge the dissemination of domestic ideology in ways not accessible to them in other genres. While the heroine's rehabilitation of her rivals works to disguise the constructed nature of her own subjectivity, eighteenth-century women writers defer this inevitable rehabilitation, prolonging the plot of female rivalry in order to analyze its conditions, and therein to call into question the social forces working to pit woman against woman. Hence, another way in which I complicate Wallace's thesis is by considering the impact of the novel on women writers and their subsequent revisions of the narrative of female rivalry. In sum, this dissertation argues that while helping to create and perpetuate the fiction of idealized domesticity, eighteenth-century women novelists also use and revise the narrative of female rivalry to undermine the construction of domestic woman.

\section{The Problems of Sisterhood: Only Part Angel}

Any theoretical examination of female rivalry must first situate itself in relationship to voluminous critical work emphasizing sisterhood and sorority. Ironically, while society has long worked to naturalize female rivalry, blaming women's essential "cattiness," feminist criticism has struggled to ignore it, instead emphasizing female community--the argument, of course, that women require a unified stance to rival the powers that be. Women, for so long divided from each other, must share a dialogue of experiences with 
each other. Indeed, in order to interrupt the narrative of unchallenged power we need to collectively resist patriarchy, in all its insidious forms. However, significant problems lurk within an idealized sisterhood.

Janet Todd, Susan Lanser, and Helen Ostovich, among others, have conducted important studies on female friendships in the eighteenth-century novel, but their attempts to bring women together in spite of their obvious differences risk glossing over the causes underlying their conflicts. ${ }^{2}$ Hence, the desire for feminist unity has meant, ironically, an outright rejection of rival narratives. ${ }^{3}$ But what happens when we eliminate rivalrous femininities and feminisms for the sake of female community? What stories must be re-told, manipulated, and/or suppressed so that they "fit" into this fiction? Indeed, we are forced to turn the other cheek to writers like Hannah More who, in Strictures on the Modern System of Education recommends the social exile of "immoral" women and Anna Barbauld who writes to friends, "There is no bond of union among literary women" (qtd. in Lonsdale 300). More and Barbauld provide an obvious problematic to the notion of sisterhood. Trying to redeem them and other wo men writers by identifying degrees of radicalism in their otherwise conservative ideologies is disingenuous and risks flattening out the diversity of women's voices. However, if we cling to the discourse of sisterhood, we have no other choice; we must either ignore them or "rehabilitate" them, thereby complying with the ironic prohibition against female rivalry. For, even while it depends on female rivalry, patriarchal ideology also outlaws competition between women as unfeminine and unsisterly.

A related problem with the notion of sisterhood is that it too easily supports patriarchal representations of femininity. We should be careful to resist the notion that 
women inherently feel connected to other women. In fact, such a conception owes itself to the powerful allure of domestic ideology and its claim that women are angelsinherently merciful, compassionate and nurturing. A dangerous, essentializing fiction, the "sister/angel" myth has left many women disillusioned because, as the conflicted history of feminism has shown us, sisterhood is not a safe haven. Says Phyllis Chesler in her sociological analysis of female rivalry, "Like men, women are only part angel; another part is pure animal" (51). Causes aside, idealizations about sisterhood are simply at odds with the reality of women's relationships with their world and each other. In fact, competition is, to some extent, natural and even positive.

The romance/marriage plot_-ironically much like feminist criticism-has long worked to expunge the animal from "woman" and displace her demons onto a rivalrous figure. Of course, in feminist criticism that rivalrous figure is often male-or identified with male power. Mainstream women who participate in "sexist" behavior are explained away as brainwashed. But placing sole blame on male institutions removes culpability from women who often participate in their own oppression. This problem resonates today-as certain academic feminists too often unwittingly suppress the voices of their "naïve" mainstream counterparts as they work to "de-program" them. "Sisterhood" works hard to rehabilitate the female outsider, to bring her into the fold, where forgiven and safely enclosed she no longer represents a threat to patriarchy. Rather than always threatened by sorority, masculinist discourse routinely relies on the ideology of sisterhood to diffuse the threat of female resistance. Hence, we need to problematize sisterhood and within it allow for competing desires and diverse definitions of "true 
womanhood"- - that is, we need to keep open the rift between women in order to explore it. $^{4}$

Perhaps most famous of critical works on female rivalry is Luce Irigaray's essay, "Women on the Market" in which she theorizes a feminist utopia within which women no longer compete with one another. Irigaray's work is especially useful for a discussion of eighteenth-century women's fiction whose depiction of female sexual rivalry does in fact offer an explicit critique of the exchange of women within the marriage market. Irigaray argues that because society assigns them value only in relation to men's desire and heterosexual exchange, women can only interact with each other as rivalrous commodities. Indeed, eighteenth-century women writers recognize each other as such and bitterly complain of the devastating effects of their commodified status within courtship and marriage. However, rather than resenting their fathers and suitors who traded in daughters for a dowry, an aristocratic title, or simply as a form of business merger between "monied" men, many women take out their anger and resentment against each other. Even with the rise of companionate marriages in the mid-eighteenth century, women recognized that their value was still primarily defined by their physical beauty (a concept largely tied to class status) and in their capacity to bear children. As such, they continued to view each other as rival commodities.

However, Irigaray's analysis does not account for the full complexity of these women's rivalrous relationships with each other. As Donna Landry and Gerald MacLean note, "the exchange of women itself is a reductive model that does not account for differences of race, class, or sexuality among women. Nor does the exchange of women explain away women's agency and complicity in oppression...." (52). The eighteenth- 
century novel is working through crises in gender, class and nationality, and depictions of female rivals are almost always bound up in the negotiation of these identities. While Irigaray's analysis might help to explain relationships between women of the same class, it does not get us very far in a reading of the rivalrous dynamics between women of different classes, nor does it help us to understand why married women (presumably off the market) and unmarried women still compete. Further, it ignores the notion that competition between women can be healthy.

Also problematic is Irigaray's utopic solution to the problem-- a return to the protective womb of sisterhood, possible only when women remove themselves from the marketplace of desire. Such a place does not exist, and the notion that these problems would be resolved outside heterosexual exchanges fails to answer for the sorts of rivalries this dissertation examines. Although domestic fiction frames all of these conflicts within the marriage plot, the complexity of women's antagonistic relationships with each other cannot be entirely explained away by their sexual commodification-- nor do their writers wish them to be. Women's aggression and "sexist" behavior - the presence of female bullies like Harriet Freke in Belinda, and to some extent, the bullying of Cecilia by Mrs. Delvile in Frances Burney's Cecilia-must be accounted for. For this reason, while relying in part on her theories, I supplement Irigaray's account of female rivalry with the works of recent theorists who, in addition to problematizing the notion of sisterhood, focus on the strategies of female rivalry and women's complicity in masculinist ideology. ${ }^{5}$

What we need is a way to conceptualize a notion of female rivalry not necessarily at odds with female community. Diana Wallace calls for "a more complex theorization 
of the effects of women's primary bonds with each other, including problems as well as possibilities...." (48). Examining feminist criticism of eighteenth-century Bluestocking Lady Montagu, Devoney Looser has similarly asked if "seeing the category 'women' as a construction — as something that does not always require solidarity in advance-[has] to be a threat? Or does seeing 'women at odds' also provide a possibility?' (57). I intend to explore these "rival" possibilities, kept open when we-both eighteenth-century women writers and the feminist critics who read them-- refuse resolution. I argue that the presence of the female rival in eighteenth-century fiction is simultaneously a mainstay of domestic ideology and a symptom of its inconsistencies. While she may function to contain competing desires, her very presence belies the stability of the marriage plot. By refusing the temptation to suture rifts between women, and instead by analyzing such gaps, we will be better equipped for an examination of the strategies of female rivalry and the forces compelling the alienation of women from each other. This is not to suggest that by doing so we can resolve these conflicts; we should not hope to return to, rebuild, or even imagine a safe place for female community. Nor does it mean we should tolerate the conditions of women's relationships with each other as hopelessly conflicted. Ra ther, it means we must understand our positions as feminist critics as negotiable and mobile-allowing conflict and difference, not closure/enclosure, to guide us.

\section{Constructing Gender: The Historical Specificity of $18^{\text {th }}$ Century Woman}

In order to understand exactly how female rivalry works both to perpetuate and challenge domestic ideology, we must first understand the historical specificity of woman as an 
eighteenth-century epistemological category. ${ }^{6}$ In part, female rivalry works to displace tensions caused by a shift in the culture's understanding of woman—a shift simultaneously responsible for and maintained by an emergent capitalist economy.

According to Ros Ballaster, literature prior to the eighteenth century offers to women two identities, "either as the ideal Petrarchan mistress, to be slavishly worshipped and anatomized...,or as the engulfing, destructive whore of libertine poetry" (73). As the idealized lover, woman is not a subject but an uncomplicated aesthetic object. Conversely, her sexually ravenous doppelganger grants her little more complexity; soulless and sexually depraved, a danger to men and social harmony, she proves ultimately resistant to education or other moral corrective. ${ }^{7}$ The latter image, the destructive whore, engulfs the ideal Petrarchan mistress: all women are whores, but some hide it better than others. This misogynist notion suffuses seventeenth-century print images, acutely represented by an anonymous French engraving entitled The True Woman, which depicts a woman strolling down a street, her frontside the version of idealized femininity, her backside hideously monstrous. Says Francois Borin of the sketch, "The devil and the woman are perfectly symmetrical, Siamese sisters. The picture suggests no mere change of mood but a simultaneous dual nature: angel and demon" (216). Her beautiful exterior masks the deviant sexual energy teeming beneath her surface. That woman possesses both the angel and devil within does not grant her complexity; her "angelic" side is as flatly good as her "devilish" side is evil. Neither speaks to a subjectivity which she can possess herself; her good and bad sides are mutually exclusive. 
In fact, rather than embodying a contest between conflicting desires, woman does not even own her own desire; she simply elicits it in others. Jacques Olivier's popular 1617 tract, An Alphabet of Women's Imperfections, scolds women:

You live here on earth as the world's most imperfect creature: the scum of nature, the cause of misfortune, the source of qua rrels, the toy of the foolish, the plague of the wise, the stirrer of hell, the tinder of vice, the guardian of excrement, a monster in nature, an evil necessity, a multiple chimera, a sorry pleasure, Devil's bait, the enemy of angels. (qtd. in Augertson 41).

If the woman of Petrarchan poetry is present only to be slavishly worshipped, her devilish counterpart is present only to entrap men. She is not subject, but catalyst for man's mistakes. She is "necessary" only to test men's virtue.

In the mid to late eighteenth century, however, woman's "monster" is exorcised to create the "angel in the house" image which will reign during the Victorian period. As this dissertation will argue, the double-headed woman of seventeenth and eighteenthcentury satires is, in the domestic novel and in the cultural imagination, split into two women: the angelic heroine and her monstrous female rival. The fundamental opposition between these two types of women works to exacerbate the ongoing crises in class, national, and gender ideologies.

Several factors conspire to alter the representation of women in the eighteenthcentury — most important among them the rise of a nascent middle-class ethos. Leonore Davidoff and Catherine Hall's classic study, Family Fortunes: The Making of the English 
Middle Class, informs the historical grounding for this project. According to Davidoff and Hall, the nineteenth-century middle-class has its roots in significant social, national and cultural changes in the eighteenth-century. In the wake of the Glorious Revolution of 1688, Parliament's power increased rapidly, although governing power still rested largely in the hands of the aristocracy. Nevertheless, sanctions against capitalist enterprise lifted, religious toleration increased, censorship was progressively curtailed, and the world of the salon flourished as propertied men participated actively, and with consequence, in political debate. These debates were aided by an exploding literary market; a growing demand for newspapers and magazines, an increasing number of independent booksellers and printers, and the popularity of circulating libraries from the 1730's on helped to construct a readership with group identity-a middle-class mentality.

Additionally, an expanding trade economy meant British citizens felt more profoundly the significance of a unified national identity. Simultaneously, the economic mobility made possible by trade created a new class of middling British citizens whose prosperity was not tied to aristocratic values but to moveable capital. Domestic fiction of the period evidences antagonism between mid-eighteenth century "monied" men, whose wealth was bound up in the market, and "landed" men, whose wealth was established by a long line of aristocratic patrilineage; however, as the century progressed and commercial enterprise expanded, the value of land gave way to liquid assets and credit became the rule of the day. As colonial markets grew, industry expanded in the cities; towns like Birmingham, which depended on coal and iron industries, doubled in size between 1740-80, and again between 1780-1800 (Davidoff and Hall 39). These newly empowered merchants, manufacturers, and skilled professionals increasingly identified 
with each other in their struggle for liberty from what was often depicted in literature as corrupt, immoral aristocratic rule. Further, developments in architecture and commercial traffic helped to make towns like Birmingham "home" to this rising middle-class.

Moreover, the rising middle class was deeply imbued with religious overtones. In the 1780's an evangelical fervor swept the nation as property owners and gentry turned to traditional Puritan values aligned with a capitalist philosophy: hard work, meritocracy, self-moderation, industry. Say Leonore Davidoff and Catherine Hall, "The moral order became a central battleground for the provincial middle classes" (26). Poets like Hannah More and William Cowper, in particular, used their literary influence to evangelize the lower classes, imagining themselves as members of a morally superior class, but one whose democratizing values could be adopted by all.

Because of these religious, political, and commercial developments, the middling ranks of British people began to imagine themselves part of an interconnected bourgeois public sphere within which they were mutually responsible for each other. ${ }^{8}$ Anchoring these changes was the figure of woman—an idyllic image of femininity quite distinct from the Petrarchan mistress or engulfing whore of seventeenth-century print imagesalthough misogynist representations stubbornly persisted for reasons I will explain later. These economic and social transformations are responsible for what Eve Tavor Bannet terms the "domestic revolution," a major epistemological shift in the category of family and of woman's place within it. Increasing industrialization meant a widening trend towards urbanization and work moved from inside to outside the home. Women who had once worked side by side with their husbands on farms or in their shops now found themselves increasingly confined to the home, their public activities curtailed. Although 
men's freedoms were growing exponentially and opportunities for social mobility expanded, women's economic dependence on their husbands increased as gender lines were more firmly policed. They could not own property, could not ask for divorce, had no custody rights to their children, and were minimally educated. In some parts of the country they were still auctioned off in a literal marriage market. Women's political influence also declined dramatically. ${ }^{9}$ The eighteenth-century Lockean ethos that all men are born into a "state of perfect freedom," one which helped to spur initial support for the French Revolution, seemingly did not apply to women.

However, the doctrine of "separate spheres," of the strictly gendered divide between public and private activity, was (and still is) a necessary fiction. Public and private are intricately connected and women, although seemingly confined to the private, wield immeasurable power in the public sphere by virtue of their idealized position in the cultural imagination. Davidoff and Hall argue, "A society based on market forces necessitated relationships beyond the grasp of the cash nexus, a site for moral orderlocated where else but in an idealized femininity and childhood, within the sacred bounds of family and home?" (xxx). Domesticity is a site of comfort, imagined as resilient to market forces, but in actuality, anchoring them. The fiction of separate spheres promises a point of origin, a space that is authentic, untainted, true. In fact, these spheres, as well as the idea of family and of gender itself, are organized by capitalist logic. Davidoff and Hall explain,

The English middle class was being forged at a time of exceptional turmoil and threatening economic and political disorder. It is at such times that the endemic separation of 
social categories, which exaggerate differences between groups, including between men and women, produces intensified efforts to create a 'semblance of order.' (30)

The notion of a privatized femininity is an ideological construct designed to confront and assuage anxieties concerning class, political, religious and national instabilities.

Ensuring that women accepted their newly circumscribed position was apparently no easy task and various texts had to be produced to naturalize this construction. The eighteenth-century's obsession with taxonomic categorization, aided by philosophical and theological discourses, worked to emphasize gender differences and to naturalize gender inequities. New medical discourse emerged to reinforce bifurcated, gender exclusive notions of sexuality. ${ }^{10}$ Religion was also a crucial component of the new ideology of femininity. Puritanism, although preaching women's dependency, granted to them an active role in the cultivation and reformation of the private sphere. Women were to be the moral guides of the middle-class family, working to reform the excess of both the upper and lower classes. Although still retaining, at her core, remnants of a dangerous sexuality, woman had learned to tame her illicit desires in exchange for the psychological rewards of social approbration. ${ }^{11}$ Janet Todd sums up the epistemological shift by the end of the eighteenth century: "In short, woman had moved from being Eve, the sexual temptress, to being Eve, the gullible mother of mankind, needing protection and condemned forever to give service" (Sign, 123). However, the new discourse of femininity, although seemingly kinder, was no less oppressive than its earlier forms. And, aided by new print technologies and wider literacy, its fiction was far more pervasive - and persuasive. 
Sexuality was perhaps nowhere more clearly legislated than in the eighteenthcentury conduct book. Nancy Armstrong explains that the conduct book, later supplemented by domestic fiction, manufactured a figure of femininity responsible for disseminating bourgeois ideology. Says Armstrong,

The curriculum aimed at producing a woman whose value resided chiefly in her femaleness rather than in traditional signs of status, a woman who possessed psychological depth rather than a physically attractive surface, one who, in other words, excelled in the qualities that differentiated her from the male. (Desire, 20)

Whereas Petrarchan poetry's idealization of woman depended on negating her subjectivity, her conduct-book version relied on the construction of an explicitly gendered subjectivity. An example of controlled desire, the modern figure of woman checked otherwise insatiable male appetites. She provided nascent capitalism and the middle-class economy with the balance of gendered desire both necessitate. Further, she reproduced her own subjectivity in her family. Texts like and George Saville, the Marquis of Halifax's Advice to a Daughter (1688), William Fleetwood's The Relative Duties of Parents and Children, Husbands and Wives, Master and Servants (1716), and Thomas Gisborne's Enquiry into the Duties of the Female Sex (1799) defined female subjectivity as they trained girls to be good daughters, wives, and mothers. Often they relied on negative exempla and "bad" women's tales of woe as warnings against submitting to illicit desires. However, while these discourses assumed the moral superiority of women, their prohibition against rival versions of womanhood implicitly 
disclosed the constructed status of idealized femininity, and the struggle to naturalize such a construction so as to contain women within their subordinate status.

The containment of woman, in large part, depended on regulating her access to knowledge, a strategy which women writers of the period are quick to expose. Writes one disgruntled woman in 1799, “[S]o jealous of their titles as lords of creation, so jealous of female rivalry in the scale of acquirement, that it has been [men's] constant study to keep women within the contracted pale of knowledge as shall prevent their approach but at an humble distance" (qtd. in Lonsdale xxxviii). Conduct books and essays in literary journals like the Gentleman's Magazine routinely urged women to privilege their domestic duties over any intellectual pursuits. In addition to proffering advice about etiquette, courtship, marital sexual relations, childrearing, and breastfeeding, most conduct books asked the same question of women's education: How much is too much? In 1763, William Rose, the reviewer for Catherine Macaulay’s History of England, worried that the "softer sex" was not suited for rigorous study. He writes, Intense thought spoils a lady's features; it banishes le ris et les graces, which form all the enchantment of a female face. Who ever saw Cupid hovering over a severe and studious brow? And who would not keep at awful distance from a fair one, who looks with all gravity of a Greek professor? Besides, severe thought, it is well known, anticipates old age, makes the forehead wrinkle, and hair turn grey...In truth, it is every way dangerous for the fair, for while they are wrapt in profound reverie, they may 
lose-We don't know what they may lose. (qtd. in

Lonsdale xxxii)

Repeatedly, women writers were warned of the negative consequence of too much intellectual activity—the loss of their sexual appeal. Further, conduct manuals advised that too much knowledge, or rather the wrong kind of knowledge, might awaken in women their repressed desires—a spectacle too frightening for Rose to imagine. The unspeakable ambiguity of what such a woman might "lose" no doubt implies the loss of her virginity and, therein, her worth on the marria ge market.

Rose's advice clearly reminds women that it is beauty, not "intense thought," which possesses value in the marriage market. Of course, conduct books did condemn those women, usually upper-class, who relied only on their beauty to attract men. However, their suggestions for "improving" female minds (learning to sew, paint, dance, and to become conversant on "appropriate" works of literature) were never for selfedification, but rather designed to enhance women's value within the increasingly popular, yet still highly problematic and largely idealized "companionate" marriage. ${ }^{12}$ In other words, readers who followed their advice were "improved" as wives—and therein, as women.

Men were not the only ones anxious about the effects of women's "intense thought." Conduct book writer Laetitia Matilda Hawkins writes in Letters on the Female Mind, Its Powers and Pursuits (1793),

That we were not designed for the exertion of intense thought, may be fairly inferred from the effect it produces on the countenance and features. The contracted brow, the 
prolated visage, the motionless eye-ball, and the fixed attitude, though they may give force and dignity to the strong lines of the male countenance, can give nothing to soft features that is not unpleasant. (197)

Like Rose, Hawkins warns that too much education will destroy rather than enhance women's desirability. Many fictional portrayals of physically repulsive women who fancy themselves highly educated, such as Maria Edgeworth's Harriet Freke and Elizabeth Hamilton's Bridgetina Botherim, evidence the power of this myth. Indeed, "force" and "dignity" were not desirable features in a prospective wife whose entire ethos would have to be based in humble submission.

However, even within women writers' apparently "sexist" recommendations to young girls we can locate elements of resistance. Hester Mulso Chapone's Letters on the Improvement of the Mind (1786) is one of these examples. Ironically written to encourage female learning, Chapone recommends limiting girls' access to education: The danger of pedantry and presumption in a woman—of her exciting envy in one sex, and jealousy in the other—of her exchanging the graces of imagination for the severity and preciseness of a scholar, would be, I own, sufficient to frighten me from the ambition of seeing my girl remarkable for learning. (qtd. in Todd, Sign 119)

Chapone's anxieties about female "presumption" no doubt rise from a sexist imagination of what it means to "improve" the female mind. Significantly, however, she does not justify women's exclusion based on their intellectual inferiority, but instead fears the 
alienating results of educating them. Chapone makes an important distinction between men's and women's reactions to an educated female. According to the OED, the eighteenth-century understanding of envy means to resent another's superior attainments and/or to covet her possessions. Jealousy refers to the fear or suspicion that a rival will displace oneself. However, Chapone is ambiguous about which sex will envy and which will feel jealousy. In one reading, the educated woman will incite envy in her lesser educated female companions and jealousy in men who will fear her as a rival for literary accolades. In the other, the educated woman will inspire jealousy in women who will fear her greater desirability and envy in men who will covet her poetic prowess. Chapone's ambiguity allows for a subversive suggestion of women's potential literary authority—curtailed only by the fear that an overly educated woman will find herself a social pariah. As Chapone insightfully notes, female education spawns female rivalry; she implicitly acknowledges that patriarchal ideology averts the threat of the female rival for male power by transferring the contest for power onto same-sex rivalry. Her subtle manipulation of sexist discourse is exemplary of the ways in which other women writers covertly revised the narrative of female competition to make room for the idea of a female intellect capable of rivaling male intelligence.

Part of the eighteenth-century debate about women's education involved the heated controversy about what constituted proper women's reading. The novel, perhaps, incited the most anxiety, dangerously inspiring the imaginations (and desire) of its female readership. Yet all reading posed some sorts of problems-primarily that those who read might be inspired to write. The threat that "public" women writers posed to patriarchy was couched in the concern that women's inferior intellect would muddy the canon of 
literature. It is significant, however, that women, rather than men, policed these boundaries. ${ }^{13}$ For example, Hannah More worries, Who are those ever-multiplying authors, that with unparalleled fecundity are overstocking the world with their quick-succeeding progeny? They are NOVELWRITERS: the easiness of whose productions is at once the cause of their own fruitfulness, and of the almost infinitely numerous race of imitators to whom they give birth. Such is the frightful facility of this species of composition, that every raw girl, while she reads, is tempted to fancy that she can also write. (Strictures 114)

More is quick to differentiate between "good" and "bad" writing, establishing for herself the critical authority to do so. ${ }^{14}$ While she begins by chastising novel writers as a whole, her gender-specific target quickly becomes clear. She focuses her criticism on "every raw girl," participating in sexist and, arguably, classist behavior if we are to read "raw" as an indictment of those from a lower economic class. Indeed, as I will later argue, her own literary rivalry with milkmaid poet, Ann Yearsley, resonates here. Her patriarchal complicity proves problematic for feminist critics because More, not willing to construct herself as a rival to male writers, readily positions herself in opposition to other women.

Elizabeth Kowaleski-Wallace discusses at length More's apparent patriarchal complicity, especially in relation to her oppression of lower-class women. KowaleskiWallace argues that in the eighteenth century the discourse of woman's subordination changed. "Old style patriarchy," secured through fear and rigid control, was gradually 
replaced by a Lockean-influenced "new style patriarchy" emphasizing natural benevolence, filial obligation and fidelity. This new form of patriarchal control, though more subtle, was no less oppressive. Much of its power lay in naturalizing the role of the "frailer sex" as helpmeet of their husbands and moral anchor of society. The ancillary power of this privatized position, which seemed an improvement over misogynist representations of public female agency, attracted women. Hence, they participated in and perpetuated oppressive masculinist and classist practices disguised as expanding feminine authority. More, and many other women writers, systematically degraded other women and excluded them from their privileged circle on the basis of their own moral superiority. Domestic ideology thus maintained masculine privilege by encouraging women to focus attention on what men defined as the shortcomings of other womenrather than on the flawed and corrupt system of their oppression. It became the duty of woman to expunge the devil from woman, to displace her onto the rival female figure and thereby contain her, distinct and distant from the angel who remains. ${ }^{15}$ Importantly, the rival figure was almost always from the lower class (More's "raw" girl) or the aristocratic class, while the angel was uniformly middle-class. Thus, female rivalry worked to construct a very class-specific figure of desirable femininity.

It would seem that bourgeois domestic ideology experienced a seamless triumph. However, as Slavoj Zizek has famously made clear, ideology is only successful when we feel no contradiction between social reality and experience. Indeed, studies of women's writing in the eighteenth-century show that the adoption of domestic ideology was not without its crises. ${ }^{16}$ Domestic ideology necessitated the prohibition of rival versions of femininity, but the need to legislate "womanhood" disclosed its fictionality. ${ }^{17}$ I contend 
that the pervasiveness of female rivalry in eighteenth-century discourse on women's education and women's writing is symptomatic of domestic ideology's internal contradictions and, moreover, that eighteenth-century female novelists depended on figures of women in conflict not to rehabilitate, but to maintain the possibilities of competing definitions of womanhood.

\section{The Rise of the Novel}

Of course, the narrative of female rivalry is not an eighteenth-century creation; "catty" women show up ubiquitously in mid to late seventeenth-century literature, specifically dramas. Dryden's The Rival Ladies, Nathaniel Lee's The Rival Queens, Robert Gould's The Rival Sisters, Thomas Middleton's Women Beware Women, and two anonymous works, The Rival Mother and The Rival Princesses, focus explicitly on dynamics between female rivals. The ubiquity of this theme in early modern literature is significant and should be examined at greater length for the historically specific work it performs. For my purposes here, however, I am interested only in focusing on how these early modern works generally differ from the novel.

Whereas the novel focused on the real and routine, the characters of dramatic fictions were often aristocratic (or ladies-in-waiting), their rivalries taking place within courts often historically or geographically distant from early modern England. Character motivations were rarely interiorized; bad girls were flatly bad, good girls transparently good. Further, their rivalries were explicitly sexual-indicative, perhaps, of the seventeenth-century's less restrictive sexual mores; novelistic versions, on the other hand, rarely discussed the sex in sexual rivalry. And while seventeenth-century plays were 
directed at large audiences, novels attracted individuals, many of them from the middling classes who read in the privacy of their own homes. This "private" act of reading, says J. Paul Hunter, clearly posed a threat to cultural values. Hunter says of the example of Defoe's Moll Flanders: "readers can be sympathetic to the heroine because they are responding alone as individuals seeing the difficulties of a particular case, rather than responding as a group with some sort of communal expectation agreed on as a result of common social and moral assumptions" (41). The novel, then, enabled greater individual interpretation, maximizing the potential for the reader's identification with fictional characters. That the readership of novels was made up largely of women, whose brains were thought to be more susceptible to influence, created even greater anxiety for social ideologues. Yet an increasing interest in women's moral improvement worked in the novel's favor as an ideological tool by which women could be instructed in making the "right" choices. ${ }^{18}$ In employing the trope of female rivalry to this end, however, the novel greatly differed from its dramatic predecessors.

To understand how the eighteenth-century novel altered the text of female rivalry, we must first consider the ideological work which it performed. Conduct books and educational treatises functioned well into the eighteenth century as training manuals not only for recommending but also constructing desirable femininity. However, conduct books and educational treatises were too explicitly pedagogical to perform the more complex ideological function of negotiating the sorts of contradictions bound up in the construction of gender identity. The rise of the novel in the eighteenth century can be explained as a response to such shortcomings. Michael McKeon argues that "the genre of the novel can be understood comprehensively as an early modern cultural instrument 
designed to confront, on the level of narrative form and content, both intellectual and social crisis simultaneously" (22). In other words, the novel's emergence evidences not the seamless triumph of conduct book ideology but rather its problems-the psychic crises experienced by those attempting to adopt it. Other forms of literature (poetry, drama) had worked to mediate macrohistorical crises at the microhistorical level.

However, it was the novel's extended interiorization of its subjects and their motives, its dialogic quality, its claims in the eighteenth century to represent life as it really was, and its appeal to the rising middle-class that enabled it both to perform such ideological work and expose what Zizek calls the symptoms of ideology.

Obviously, one eighteenth-century epistemological crisis occurred at the level of gender formation. Janet Todd says of the shifting definition of femininity across the eighteenth century: "Between Aphra Behn in the 1670's and Mary Wollstonecraft in the 1790 's is a century of sentimental construction of femininity, a state associated with modesty, passivity, chastity, moral elevation and suffering" (Sign 4). Although useful, Todd's charting of this transformation fails to link the novel to the success of sentimental constructions of womanhood. Further, she does not contest or complicate women's docile acceptance of the prevailing definitions of femininity.

Since Todd's study, several critics have examined at length the dual emergence of the novel and the "angel in the house" construction of femininity. Nancy Armstrong, for example, has argued that "the rise of the novel hinged on a struggle to say what made a woman desirable" (Desire 5). The heroine served as an exemplary model of middle-class virtue with whose desire her readers could identify and whose desirability they could imitate. However, if Armstrong is exclusively interested in how a particular figure of 
womanhood rose to negotiate class crises, I am interested in how tropes of female rivalry surfaced to deal with the fissures implicit in the eighteenth-century construction of ideal femininity. In fact, the rise of the novel depends as much on the need to work through crises in gender as in class. Helene Moglen suggests, "It was in the novel, more than in any other expressive form, that the social and psychological meanings of gender difference were most extensively negotiated and exposed" (4). Moglen's work helpfully recovers what she terms the "bimodal" form of the novel, its dialectic tension between realism, "the self in its moral, ethical and psychological relationships with others," and fantasy, "interior states produced by possessive and affective forms of individualism" and which "exposed the anxious melancholy that the modern order of social differences induced" (5-7). ${ }^{19}$

The novel's potential to work out crises in the epistemology of gender might help to explain why so many women were drawn to the genre, both as readers and writers. Josephine Donovan reasons that "[b]ecause of its unique blend of realism and critical irony, the novel can foster ethical understanding of individual characters' plights and of the forces responsible better than perhaps any other medium" (5). Women experienced a communal sense of frustration and resentment at their reinforced sexual objectification within nascent capitalism. A growing middle class meant more women had the leisure and finances to write than their ancestors. Thus, the novel, so often centered on courtship and marriage, provided women with "a critical, ironic standpoint from which to judge the machinations of the exchange system" (Donovan 17). Thus, while the novel could be used to support patriarchal interests, constructing a figure of woman conducive to maintaining its dominance, it also housed subversive voices. 
Similarly, Paula Backscheider finds the form of the novel especially conducive for making feminist statements. She explains that novels made audible the voice of the Other, a site of opposition to dominant ideology which women occupy. Like Donovan, she believes that the dialogic quality of the novel incited its readers' responses, calling on them to interact with, interrogate and judge characters and plots which often involve female experience. Backscheider also suggests that the dialogic nature of the novel, enabled by the radical cultural transitions of the eighteenth century, opened up a specifically liminal space between fiction and reality within which readers can contest and clarify identity ("Liminal" 18). As a relatively new genre, the novel occupied an ambiguous conceptual space, as did its author.

If readers were drawn to the novel for its subversive purposes, so were authors. Certainly the author composing the novel was actively engaged in the experience of liminality, moving between individual and collective consciousness, between trope and revision—and at least for the Anglo-Irish Edgeworth, between national identities. The very liminality of the eighteenth-century novel's space, its ambiguity, its lack of clear, taxonomic definition, could be occupied and used subversively. How, then, did society react to an increasing number of women writers on the literary market?

\section{Women at Odds: The Threat of the Women Writer and Female Community}

In a 1752 piece in The Adventurer, no 115, Samuel Johnson writes,

The revolution of the years has now produced a generation of Amazons of the pen, who with the spirit of their predecessors have set masculine tyranny at defiance, 
asserted their claim to the regions of science, and seem

resolved to contest the usurpations of virility. (qtd. in

Lonsdale $\mathrm{xxx}$ )

Johnson's observation about women's usurpation of masculine territory is supported by historical evidence. The number of women publishing between 1750 and 1800 doubled each decade. In fact, after 1720, fifty-one percent of literature published was by women. ${ }^{20}$ Although women writers published comedies, tragedies, gothic fiction and poetry, their largest contributions were to domestic fiction; between 1760 and 1790, twothirds of epistolary novels published were by women. ${ }^{21}$ The domestic novel, involving matters of the heart and home, enabled women of the middling ranks to share their experiences_-and sometimes to complain about them. In as much, the domestic novel performed a double function. It continued a long pedagogical tradition designed to secure masculine privilege, but because of the significant numbers of women writing the novel, it was also used to question that tradition and its teachings.

Of course, the tendency in criticism of the rise of the novel is to start with either Defoe or Richardson; I do so myself for reasons I will explain below. However, at least one critic has convincingly suggested that the novel emerges out of a feminist tradition. Josephine Donovan has argued that early women recognize the subversive potential of the casuist tradition: circumstance can challenge prescription. Like Spencer, Donovan maps the transformations of the novel in response to changing social conditions, although her focus is less on gender construction than on drawing a timeline for the realist tradition. Beginning with courtly love poets, she traces a tradition of feminist casuistry from Christine de Pizan, through Marguerite de Navarre and Maria Zayas, to Margaret 
Cavendish, Mary Carleton, Delarivier Manley, and Jane Barker. She suggests that the novel owes its rise to the French framed-nouvelle, which kept in tension inset narratives and the narrator's voice.

Sandwiched between the framed-nouvelle and the novel were women's autobiographical fictions; authors used their own lives as case histories to test ideological maxims. Because of their increasing isolation from the public world, women "needed a voice; they needed to feel that they had agency, that they were participants on the human stage and could affect some of the events of their domestic circumstances and their own society"(Donovan 41). In addition to connecting women to each other, writing helped bridge the divide between public and private, making women feel part of, indeed integral to the workings of, the world outside the home.

As women's literacy rates inc reased in the eighteenth century, albeit at a slower pace than men's, more and more women published. Jane Spencer has identified several factors contributing to women's increased authorship: the weakening of the Latin rhetorical tradition, movement away from a patronage system to the book market and, perhaps most importantly, the legitimation of women's domestic experiences due to an increased value for the experientially verifiable. Another contributing factor was women's worsening economic situation because of the division of public and private spheres; for many, authorship was the only socially acceptable form of women's paid work.

The Bluestocking Circle is probably the most renowned of communities of women writers, famously celebrated by Hannah More in her poem Bas Bleu (1787). Popular through two generations, these "first feminists" helped to popularize the salon in 
London, but more importantly formed support for fledgling women writers and encouraged female education. Gary Kelly explains the impact of emergent capitalism, the rise of the middle-class, and civic humanism on women in the eighteenth-century, and suggests that Bluestocking feminists, while a product of these cultural transformations, also dialectically contributed to the feminization of culture and the articulation of gender difference. Championing female education and intellectualism, eighteenth-century Bluestockings helped to construct a historically specific notion of womanhood bound up in notions of evangelical philanthropic activism, feminine sensibility, and a democratic and democratizing notion of virtue. The Bluestockings met with much critical support and even inspired painter Richard Samuel to create the 1775 portrait, "Nine Living Muses of Great Britain," memorializing Montagu, Carter, Lennox, Macaulay, Barbauld, Griffith, Kauffman, Sheridan and More. ${ }^{22}$ This print would seem to suggest what critic Elizabeth Eger calls “a metonym for women's involvement in the cultural world of their time...evidence of the iconic status granted to 'literary women' as a collective class" (126). Indeed, Samuel's print indicates a much larger trend celebrating female intellectualism, as in literature like John Duncombe's The Feminead; or, Female Genius, A Poem (1754) and George Ballard's Memoirs of Several Ladies of Great Britain (1752).

While some reserved praise for women intellectuals, others like Johnson were less welcoming, anxious about women's usurpation of a hitherto predominantly masculine terrain. Yet critics of women's writing were treading a thin line. If women writers confined their subject matter to heart and home, they, as the moral supervisors of society, contributed to the feminization of literary culture. This was to be celebrated. Yet in having such a public effect, they contested the prevailing notion of femininity. They also 
dangerously rivaled men's long-held literary authority. In effect, anxieties about women's writing were strategically nestled into uncontested notions of feminine propriety-displaced onto accusations of wo men's sexual transgression. Charles Gildon's 1702 play, A Comparison between the Two Stages, evidences such anxiety. In it, the character Chagrin the Critick asks, "What a Pox have Women to do with the Muses? I grant you the poets call the Nine Muses by the names of Women, but why so? Not because the Sex has anything to do with Poetry, but because in that Sex they're much fitter for prostitutes" (qtd. in Spencer 26). Later he complains, "I hate these Petticoat-Authors; 'tis false grammar, there's no Feminine for the Latin Word, 'tis entirely of the masculine Gender and the language won't bear such a thing as a She-Author" (qtd. in Spencer 27-28). Jane Spencer notes that the play remained popular for decades, testifying to the resiliency of such hostility. Pope's The Dunciad (1728) reflects a similar unease, depicting authors Eliza Haywood and Susanna Centlivre as unkempt hyper-sexual deviants. The eighteenth-century understanding of womanhood, which linked inextricably women's minds and bodies, made it easy for the public to align women who wrote for the public with prostitutes. ${ }^{23}$

Alternatively, women writers who transgressed gendered boundaries were figured as unsexed. Aphra Behn was accused of sexual anomaly in A Session of Poets (1688): "Since her Works are neither Wit enough for a Man, nor Modesty enough for a Woman, she was look'd on as an Hermaphrodite, \& consequently not fit to enjoy the benefits \& Privileges of either Sex, much less of this society." Although Virginia Woolf would later credit Behn with having paved the way for the social acceptance of women writers, a century after A Session of Poets was published, women writers continued to meet with 
similar critical rhetoric. In 1794, Thomas Mathias complains, "Our unsex'd female writers now instruct, or confuse, us and themselves, in the labyrinth of politics, or turn us wild with Gallic frenzy." Here, Mathias links these "unsex'd" writers with the French Revolution, clearly blaming their ambition on "radical" enlightenment egalitarianism. On the heels of Mathias, Richard Powhele publishes his poem, “The Unsex'd Females” in 1798. In it he discloses anxieties about the gendered transgressions committed by women writers:

Survey with me, what ne'er our fathers saw,

As 'proud defiance' flashes from their arms,

And vengeance smothers all their softer charms,

I shudder at the new unpictur'd scene

Where unsex'd woman vaunts the imperious mien. (lines 11-15)

Although Powhele figures both Behn and her descendants as unsexed, certain changes in the rhetoric are significant. Behn's transgression renders her hermaphroditic-asexual and not necessarily threatening. But because gender differentiation had become more rigidly enforced, women writers of the mid to late eighteenth-century were guilty of a trans vestivism that revealed the constructed and arbitrary nature of gender assignation. An "unsex'd" woman was not without sex; she was both feminine and masculine and therefore doubly dangerous. The popular trope of the Amazonian woman writer, wielding her pen as her weapon, was routinely contrasted with more acceptable models of modern femininity.

Women who wrote for public accolades were guilty of disrupting the social fabric, and concerns about their ambition were also couched in fears that they would 
forgo their primary duty, childrearing. One oft-quoted 1712 essay from the Spectator reads, "The utmost of a woman's character is contained in domestic life; first, her piety towards God; and next in the duties of a daughter, a wife, a mother, and a sister" (qtd. in Lonsdale xxiii). Women were the backbone of public life; a successful capitalist economy depended on their reproductive labor within the home as well as their management of the household. The writer seems to implicitly ask, if the "utmost of her character" was therein "contained," what could possibly be left over for literary pursuits? Another essayist in an April 1756 edition of The Universal Visitor wonders what is to be done with the growing number of women writers who don't fit into any clear ge nder assignation: "Authoresses are seldom famous for clean linen, therefore they cannot make laundresses; they are rarely skillful at their needle, and cannot mend a soldier's shirt; they will make bad sutlers, being not accustomed to eat." The domestic and public spheres were imagined as mutually exclusive. The suggestion is that a woman could not be successful at both writing and wifehood. Yet the writer's unease undermines the notion of a "natural" femininity, evidencing instead its constructed nature—and that women might choose to refuse to perform it.

Dale Spender, citing a reviewer in a 1762 edition of the Gentleman's Magazine, suggests that women's writing also threatened to disrupt class stability. The reviewer writes: "We are usually tender of the productions of the female pen; but in truth, the number of authoresses hath of late so considerably increased that we are somewhat apprehensive lest our very Cook-wenches should be infected with the Cacoethes Scribendi, and think themselves above the vulgar employment of mixing a pudding, or rolling a pye-crust" (qtd. in Spender 472). The writer suggests that while society might 
accept a few anomalous women writers, such intellectual activity would not be tolerated in all. As noted, the concern was not just that women might forget how to cook well, but that they might begin to pride themselves in accomplishments that lay outside the household. Such ambition was especially dangerous for women of the lower class. Hannah More said as much when she worried about ambitious "raw" girls.

The threat posed by the woman writer was based on more than her encroachment onto male territory and the destabilization of class lines. What women were writing about was private experience—courtship, marriage, childbirth, and childrearing — and they necessarily threatened to expose the ideology of their domestic entrapment and, hence, the conditions by which male privilege was maintained. The epistolary novel, especially, posed a threat because of its close relationship to gossip. Says Kathleen M. Brown of the threat of women's gossip: "Relationships forged through whispered information and shared judgements— the juridicial side of female gossip—often spilled over into the heterosocial public...In its juridicial and community-defining roles, gossip was perhaps the closest thing to a female public" (89). When women wrote, they circulated female knowledge, making private experience public. ${ }^{24}$ In fact, the term "gossip" derived from the all female group of kin and midwives present at seventeenthcentury birthing rituals. When male doctors appropriated this space in the eighteenthcentury, they associated "gossips" with antiquated rituals and superstitions. There is certainly a significant connection between the ways the culture imagined seventeenth century midwives and eighteenth-century women writers who "gossiped" about private experience. Both laid claim to a realm of certain female authority, and in strikingly 
similar ways, both were bound up in the reproduction and circulation of female experience.

It is no surprise, then, that communities of women writers (like midwives in eighteenth-century medical treatises) are often figured as a dangerous cabal. The following excerpt from Modern Poets (1791) draws analogies between women writers and a coven of witches:

See Phoebus trembling on th' Aonian hill

The clamorous Fair surround—en dishabille;

Like flocks of geese Saint Michael's day that bless,

Not less their numbers, nor their cackling less.

What troops of Druidesses now assail,

Their meteor-hair streams around their visage pale,

All grim with snuff their nose, and black their length of nail. (qtd. in Lonsdale xxxvi)

These women writers, the authors of the modern age, are for this writer a frightful sight. What is feminine about them, their dress, long hair, fair skin, is terrifyingly exaggerated. The Bluestocking Circle certainly received its fair share of similar criticism. Gary Kelly notes "the vulnerability of Bluestocking salons to association with courtly salons...in the satires and innuendoes that suggested a hidden agenda of sexual intrigue" (171). Sylvia Harcstark Myers also discusses the hostility met by the Bluestockings in Charles Pigott's essay Female Jockey Club (1794), comic operas like Thomas Moore's M.P; or, The Bluestocking (1811), romantic poetry, like Lord Byron's The Blues: A Literary Ecologue 
and his epic Don Juan (1821). It seems as often as literary ladies were celebrated, they were also depicted as objects of ridicule.

Depictions of groups of intellectual women as hideous, sexually transgressive witches evidences anxieties felt by eighteenth-century society about who had the right to create and disseminate knowledge. Susan Lanser suggests, “The fear that women might bond for public purposes might also explain why discourses about single women, in this period most frequent in England, present them not as loving friends but as solitary menaces or in dangerous groups toxic to marriageable women"(180). The imaginative presence of such toxic groups served a dual purpose. First, it attempted to discourage, however unsuccessfully, female publication; moreover, it discouraged female homosocial intimacy. If well-bred, polished women like the Bluestocking circle could become victims of such satire, no female enclave was safe. What woman writer would want to be part of a group that might potentially become the target of social disdain? Such depictions thus created a climate of general apprehension among women. Further, women writers were all the more likely to participate in attacks on other female groups in order to distance themselves from accusations of impropriety as well as to differentiate their own friendships from those under fire. This is clear in Hannah More's indictment of "raw girls" who imagine themselves authors, as well as in the trenchant efforts made by later eighteenth-century women writers to distinguish themselves from the then unfashionably racy Behns, Haywoods, and Manleys. ${ }^{25}$

Of course, feminist responses to such defamation were plentiful, evidenced by the pamphlet wars of the eighteenth century and the publication of numerous defenses of women, written by both men and women such as Mary Lady Chudleigh's The Ladies 
Defence (1701) and To the Ladies (1703), The Sophia Pamplets, like Women Not Inferior to Man (1739), Mary Hays' Appeal to the Men of Great Britain in Behalf of Women (1798), and, of course, Wollstonecraft's Vindication of the Rights of Woman (1792). However, it is crucial to recognize that there exists no simple binary dialogue (feminist versus anti-feminist). Critics have unearthed a complex web of multifarious "feminist" and "anti-feminist" positions. Bluestocking women like Hannah More were as quick to celebrate women writers like the virtuous Katherine Philips as they were to condemn radicals like Mary Wollstonecraft. Similarly, Powhele reserved praise for poets like More while chastising her contemporaries Mary Robinson and Charlotte Smith. No concrete articulation of femininity emerges out of this complicated matrix of conflicting epistemological positions; rather, these controversies expose a historically specific project of gender construction. The debate about women writers is thus part of a larger ideological dialogue working, dialectically, to construct an image of femininity most useful for reinforcing the social hegemony. How did these competing images of femininity break in on, interrupt, and challenge the otherwise seamless narrative masculinist discourse tried to construct? And, what part did eighteenth-century domestic fiction play in both circulating and revising masculinist discourse?

\section{Female Rivalry as Novelistic Trope}

As I have suggested, the significant number of women writing and publishing in the eighteenth-century induced patriarchal anxiety. Myriad essays, poems and dramas warned women against trusting other women and "exposed" circles of female friends as dangerous, sexually deviant cabals. However, it was in the novel, under the guise of 
benevolent moral instruction, that the most hostile attack against female community was launched. Ironically, the genre that would serve to celebrate female experience and connect women to each other became the means by which they learned to distrust such connections.

Chapter One examines Richardson's Clarissa in terms of the female rivalries and betrayals that dominate its pages. Although many critics have praised Richardson's patronage of communities like the Bluestocking Circle, I argue that underlying his seeming support of women writers are tremendous anxieties about the instability of both male authorial power and the fictions of domestic ideology. A close reading of Clarissa also discloses Richardson's fears about uncensored female community and communication. In fact, the male editor, who I argue is aligned with Richardson, maintains control of the narrative's trajectory through editorial interjection...much the same way that Lovelace edits Clarissa's letters. As I will argue, the depictions of the women of the Sinclair brothel, who imprison and menace Clarissa, call to mind fears about women writers circulated in eighteenth-century literary discourse. Moreover, Richardson uses the narrative of female rivalry to displace anxieties about female homosocial intimacy. The recurrence of disappointing and/or dangerous female intimacies, for example in the familiar narrative of the "orphaned" female surrounded by monstrous mother figures and rivalrous sisters, clearly works to regulate and normalize the fiction of an exclusively heterosexual and heterosocial economy by fostering a climate of mistrust within communities of women.

Richardson's novels are, by most accounts, responsible for trade-marking the literary conventions of the eighteenth-century romantic love plot and domestic ideology. 
His configuration of feminine virtue, of marriage, and specifically, of female friendships dramatically affected subsequent "revisions" of the romance plot by both women and men, but women writers, in particular, felt the anxiety of his influence. It was from within this icy ideological climate that women writers responded, re-imagining in their own novels the context of female intimacy in order to affirm both its viability and necessity. Ironically, they re-established female bonds through the trope of female rivalry.

Women writers who relied on the trope of female rivalry were not oblivious to the problems of perpetuating their own sexual objectification. Audrey Bilger's work on women's use of satire in conduct book literature is significant for its explanation of women writers' subversive use of misogynist caricatures of other women. Says Bilger, "In the works of eighteenth-century women writers, we can see the simultaneous longing and revulsion that can characterize women's relations with other women, a longing for some kind of female community coupled with a revulsion toward those whose behavior gives women a bad name" (147). While immensely useful, Bilger pays only brief attention to competitive women, concentrating solely on their satiric representations. Her argument, because of its focus on caricature, tends to flatten out the complexity of these depictions; moreover, she fails to account for the impact of the novel's formal qualities on these depictions.

Indeed, novelistic discourse enabled women writers to complicate simplistic good girl/bad girl dyads like those in early modern plays such as The Rival Queens, Women Beware Women, and The Rival Sisters. The dialogic nature of the novel encouraged an interrogation of the motives underlying "bad girl" behavior which thus worked to 
complicate idealized femininity. In fact, although the women novelists I examine-- Sarah Scott, Frances Burney, and Maria Edgeworth--seem to suggest the need for a female collective, their proclivity is for communities composed of conflicting femininities whose tensions remain unabashedly unresolved. I contend that female rivalry in eighteenthcentury novels written by women performed a complex double function, both reinscribing domestic ideology and undermining it.

Chapter Two examines Sarah Scott's attempts to resolve the problem of female rivalry. I have chosen to start with Millenium Hall (1762) for several reasons. The novel calls attention to the ways in which women are culturally constructed to view each other as rivals in a market with limited opportunities for economic advancement. However, rescued from a cold, unfeeling world and re-established within the safe haven of Millenium Hall, women come to depend on and trust each other. I argue that Scott revises Richardson's dangerous female cabal in Clarissa to create an all-female community that, while offering a safe alternative to a dangerous marriage market, does not pose a threat to the heteronormative framework. Although conventionally complete with orphaned heroines, tyrant mother figures, rivalrous female coquettes, and Solmes and Lovelace-like suitors, this interpolated tale distinguishes itself from Richardson's Clarissa because its heroines salvage female friendship, explicitly and repeatedly faulting social convention for female rivalry. However, it is crucial that Millenium Hall is a utopia; that is, it is a fantasy. Scott is able to bring female rivals into an enclosed space within the pages of her fiction and create a sense of sorority, enabling a dialogue between them as well as between her characters and her readers. However, the utopian novel is problematic because, as Zizek makes clear, “'utopian' conveys a belief in the possibility 
of a universality without its symptom" (23). Like the womb of sisterhood, no such place exists - its very fiction conveys the totality of ideological power. As feminist scholars, we must be suspicious of utopic sorority. Scott's arcadia is representative of the pervasiveness of domestic ideology and suggests ways in which it is able to recover and contain resistances to it. Nevertheless, Scott's novel is a striking example of the ways in which women writers could resist tropes of female rivalry while disclosing the forces of a masculinist ideology which pits women against each other.

My discussion of Frances Burney in Chapter Three focuses primarily on representations of female friendship and rivalry in Cecilia (1782). Written thirty-five years after Clarissa, the novel, like Richardson's, constructs the figure of the besieged female paragon. Orphaned and left with a great fortune that, rather than empowering her, impedes her happiness, Cecilia is without a single, reliable, female friend to help guide her. Instead, the women she encounters prove ineffectual role models and allies. However, in contrast to Richardson and like Scott, Burney implicitly identifies patriarchal and domestic ideology as forces disabling female sorority. Whereas in Richardson's novel misreading is a marker of an essential female deficiency, in Cecilia Burney implicitly blames domestic ideology and the literary tradition by which it is propagated for women's faulty interpretative skills. Moreover, I argue that ideological conflicts involving class mobility, patrilineage, and romantic love get displaced onto a tug of war between Lady Delvile and Cecilia for Mortimer Delvile's affections. I explore the motivations for Lady Delvile's apparent patriarchal complicity and, additionally, her "bullying" of Cecilia in light of recent critical work on strategies of indirect female aggression. Further, I consider the function of female hysteria, which figures 
significantly in Burney's text-- as is typical of eighteenth-century sentimental fiction. However, hysteria in Burney's novel is not rooted in the body, nor in an essential feminine weakness, but is an effect of misogynist conventions which foster female rivalry. I also argue that Burney contrasts the intensity of female friendship with impotent, inadequate heterosexual alternatives. Burney depicts men as gaps in the narrative of female friendship, representative of a problematic ideology unable to imagine authentic and fulfilling intimacies between women outside a heterosexual and heterosocial narrative.

Maria Edgeworth's novel Belinda (1801), which I discuss in Chapter Four, also emphasizes the relationships between female characters over the heterosexual narrative, even when those relationships are rivalrous. Like Burney, Edgeworth relies on the tropes of the orphaned heroine, aggressive female rivals/bullies, and ineffectual "heroes," and repeatedly suggests female rivalries are the products of misreadings for which she selfreflexively faults conventional romantic ideology. Similarly, she satirizes the conventions of domestic ideology and the romantic love plot that would thwart necessary female intimacies and, in her revision, suggests that female community is to be salvaged at all costs. In fact, as in Cecilia, the result of alienating women from each other is madness and hysteria. While the novel's close seems to reinscribe domestic ideology, it also suggests Edgeworth's lack of confidence in domestic ideology; unlike Scott, she cannot imagine a place for successful sorority. Most obvious is the contrast between Scott's Millenium Hall and Edgeworth's dystopic Harrowgate. Yet Edgeworth's use of grim irony throughout the novel makes clear that the blame for deviant female homosociality, as at Harrowgate, falls on society's abuse of women within the marriage 
market. Less a scathing portrayal of female sorority, Harrowgate is emblematic of women's desperation to maintain female friendship even in the face of social stigmatization.

In returning to the eighteenth-century I hope we might learn from the strategies employed by these women writers who learned both to live with rivalry between women and to re-see female rivalry as potentially revisionist. In my conclusion, I briefly address some of the historical rivalries between women writers, for example Anna Barbauld and Mary Wollstonecraft, as well as those rivalries constructed by the cultural imagination, as in the Astrea/Orinda divide which characterized the earlier half of the eighteenth century. These historical rivalries, in addition to figuring implicitly in fictional portrayals also importantly tell us about the conditions of women's "real" relationships with each other, help to explain women's engagement in apparently "sexist" behavior, and suggest that writing fiction was one way these women were able to work through and negotiate their differences-if not to resolve them.

Certainly I have had to live with my own embittered feelings towards writers like More and Barbauld who so brazenly assault that paragon of feminist virtue, Mary Wollstonecraft. But I dare not try to bring them "into the fold" of a sisterhood that did not exist then-and which does not exist now. If female rivalry forces us to choose sides, to choose against certain histories (her stories?), it also engenders reflection and dialogue. It thrives on difference and eschews tolerance, a term that reeks of hierarchy and privilege. It demands that we take responsibility for our choices and, as we battle, to negotiate continually our positions and revise our strategies. For these reasons, we must 
choose to live with female rivalry. And in resolving to live with female rivalry perhaps it will become a little easier for all of us to live with ourselves. 


\title{
Chapter One:
}

\section{"their Helping Hands": Domestic Violence and the Complicity of "Bad" Girls in Samuel Richardson's Clarissa}

\begin{abstract}
Richardson's novel, Clarissa (1748-49), has oft been credited with shaping novelistic discourse. Ian Watt asserts, among other claims, that Richardson's attention to the psychological complexity of his characters is unprecedented in literary history. This was an opinion shared even during Richardson's time. His French contemporary, Rousseau, wrote that "no one, in any language, has ever written a novel that equals or even approaches Clarissa" (qtd. in Watt 219) and in her introduction to her collection of his correspondence in 1805, Anna Laetitia Barbauld was to term Richardson the "father of the modern novel" ("Richardson"). Of course, critics following Watt have since challenged what he argues is Richardson's proprietary claim on the novel, identifying masculinist assumptions that have long obscured a rich history of women's writing. Nevertheless, the impact of Clarissa on the eighteenth-century epistemology of the novel cannot be underestimated. After all, although the longest book in the English language, it was widely read throughout the eighteenth-century, was published in four editions in Richardson's lifetime, was translated into Dutch and into an abridged version in French, and generated numerable imitations across the continent.
\end{abstract}

Of course, a force like Clarissa works not only to shape literary conventions, but the cultural imagination and social landscape. Revisiting Watt's thesis that the novel owes its rise to an emergent middle-class, Terry Eagleton suggests that Clarissa not only 
reflected, but actively helped to formulate a specific class mentality; Richardson's novels are the "organizing forces of what...we may term the bourgeois "public sphere"” (6). In other words, the novel, like others of its day, worked to impress on readers a certain mode of behavior consistent with a middle-class ethos. It accomplished this task largely through the figure of an idealized and apoliticized femininity, as articulated by Nancy Armstrong in Desire and Domestic Fiction. Clarissa, like her predecessor Pamela, reforms those above and below her by exhibiting the self-regulation and introspection that would become the hallmarks of middle-class citizenship.

Because of the ways in which class and gender production inextricably are linked, Clarissa (both novel and cultural phenomenon) has become an important site of consideration for academic feminists interested in the ways in which it figured in the production and circulation of gender in the eighteenth century. Jerry Beasley, for example, suggests that Richardson passed on a mixed legacy, especially for its largely female readership:

Clarissa was in its time...powerful for male readers, we may assume, because the elaborated rendering of the familiar pathetic female evoked intensively cathartic sympathy and compassion while in no way undermining their own gendered position of dominance; [it was also] powerful for women, both positively and negatively, because the grandeur of Richardson's conception of the female was unprecedented, and because his portrait of Clarissa really does elevate womanhood by celebrating 
female strength, intelligence, and verbal prowess, even as it

uses that portrait toward affirmation of the divinely

ordained structure whose corrupted worldliness actually

causes Clarissa's death. (79)

Although Clarissa works to reform the bad behavior of those around her, in order to do so she must submit to their misogynist ideology and, ultimately, forfeit her life. Male privilege is underpinned by female sacrifice. Thus, Beasley calls Clarissa, like Richardson's other novels, both "a burden as well as a blessing to the many women who admired and learned from them—learned something of their craft, if they were writers, learned also of the willing restraint on their aspirations to full independent selfhood and freedom of expression that was expected of them as people" (90). Indeed, as my next chapters will suggest, Richardson leaves to writers following him, many of them women, a vexed inheritance. Ruth Perry concurs, "Clarissa functioned as a lodestone, exerting its enormous force on the themes and structure of women's writing and re-orienting their narratives" (119). The writing of women was affected by what they read in Clarissa; arguably, so too were their own lives. I suggest, in particular, that their views of female intimacy, and the ways in which they conceptualized and formed friendships between women was highly influenced by the example set by both Clarissa and its eponymous heroine. $^{26}$

Following Watt, feminists have struggled to make sense of the novel's (and its author's) ideological leanings. On one hand, Richardson was a strong supporter of women's issues and a dedicated mentor to a number of fledgling women writers from whom he regularly solicited advice as he drafted Clarissa. Elspeth Knight s notes, in fact, 
that he relied on some of their experiences with a misogynist society for the plots of his novel. ${ }^{27}$ Seemingly, Clarissa's heartbreaking experiences serve as an indictment not only of aristocratic and working-class corruption, but of a social system oppressive to women. Thus, many have argued for Richardson's proto-feminism. ${ }^{28}$

Yet Richardson is also staunchly patriarchal, asserting a paternal control over the women with whom he corresponded. Knights's thorough examination of Richardson's relationship with his female coterie suggests that although Richardson resisted their tendency to figure him as a literary "father," his correspondences to friend and fellow author, Aaron Hill, make explicit his patronizing view of women. In his letters, he clarifies his expectation for a higher level of sophistication from male respondents. Further, his letters to his female readers are often "teasing" and "uncannily manipulative" (Knights 230). Terry Eagleton agrees that "the printer remains master, coyly leading his readers up the garden path only to regroup them submissively around him in the grotto" (27). As this chapter will flesh out more fully, Richardson, even while seeming to resist the role of patriarch, nevertheless practices the strategies of patriarchal control.

It is not, however, simply Richardson's interactions with his women readers that suggest his masculinist impulses. He manipulates the very form and content of the novel to maintain authorial control and, ultimately, male privilege. While the epistolary structure of the novel readily invites readers' desire to intervene in the narrative, Richardson refuses to cede control. In fact, Martha Koehler has suggested that Richardson's use of the epistolary mode is unique in that he manages to "extract a binary model of communication from an implicitly triangular one" (154). In other words, 
Richardson eliminates what Michael Serres calls the "noise" of the third party, i.e, undesired interpretations, and in doing so commands his ideal reader response. ${ }^{29}$

Ellen Gardiner, too, has asserted that "in Clarissa, Richardson appropriates, manipulates and exploits the century's new concept of literary property as a means of increasing his own control over the text and limiting his audience's appropriation of Clarissa's story" (40) and "especially in the formal apparatus of his novel...Richardson represents the moral, middle-class male editor as the best judge and interpreter of what transpires in the narrative" (43). She notes in particular (as does Koehler) the novel's emphasis on women's poor reading skills and Richardson's consistent editorial interruptions of Clarissa's letters. She also argues that Clarissa only gets herself into trouble when she tries to practice the critical, interpretative, and writing skills normatively associated with masculinity. Her emotion gets in the way. Thus, "Lovelace's fictions force Clarissa to recognize her own unfitness as an editor" (53). Clarissa's willing of her text to Belford cements Gardner's convincing argument against Richardson's “feminism.”

Paula Backscheider, too, disagrees with those who claim Richardson as protofeminist, arguing "that Richardson inscribed the patriarchy approvingly on Clarissa's death, raised the stakes for women in these debates, and left a dangerously mixed legacy for his so-called female imitators" (32). She notes that the ending of the novel in particular works to "deflect novelistic discussion away from feminist concerns" in so far as it "impose[s] a resolution on problems and contradictions that women's fiction had made apparent" (42). In other words, the less than exemplary conduct of earlier heroines 
worked to expose a hypocritical world. In pre-Richardsonian texts, "the condition of women prevents fulfillment, security, and happiness" (48); they rarely end "happily."

Backscheider notes a number of ways in which Richardson defuses the potential for feminist challenge. Additionally, I argue that the narrative drive of Clarissa works to displace masculinist anxieties about women's increasing agency onto conventional tropes of female rivalry. The flatness of the good girl/bad girl binaries around which the text is organized and on which its didacticism largely depends contrast starkly with the psychological complexity praised by many of his critics. I argue that Richardson's concerns about the potential of female literary communities to disrupt the heterosexual norm and destabilize patriarchal privilege structure his novels. Employing a divide and conquer strategy, Richardson depends on cultural assumptions about women's inherently jealous natures. While he seems to lament the absence of reliable female communities which might otherwise save Clarissa, he simultaneously relies on the demonization of "bad" girls both to limit women's creative and interpretive skills, and to ensure that men, not women, maintain discursive control. Richardson, like Lovelace, uses the bodies of "bad" women to siphon blame away from men for their cruelty to women; the effect is a chilling negotiation of empathy for Lovelace and the maintenance of the misogynist system he represents.

Richardson's personal anxieties about women's increasing agency reflect larger cultural concerns about women's place in society. Reading Clarissa in the tradition of captivity narratives, Nancy Armstrong has examined historical evidence of women's increasing unwillingness to bear their husbands' abuses of powers. Looking at petitions submitted to the Consistory Court in the eighteenth century, Armstrong notes the 
women's use of captivity metaphors to call for social reform, especially among men. Clarissa, she says, signifies this gendered tug-of-war; its eponymous heroine figures herself as the captive of both Lovelace and an abusive patriarchal society. Armstrong suggests that the novel demonstrates Richardson's desire to create a new sense of nationhood founded on reformed masculine authority. Yet Armstrong's analysis opens up a possibility she does not explore: that the conflicts between men and women get displaced onto struggles for power between women, and that the heterosexual rivalry which might otherwise threaten the status quo is defused within the depoliticized spaces of domesticity. The real captors, the novel implies, are women. ${ }^{30}$ I argue that what we see at work in Clarissa, by vehicle of conventional female rivalries, is the manufacture of the class specific, exclusively heterosexual, and thoroughly masochistic version of femininity on which eighteenth-century male privilege depends.

\section{Clarissa Vs.... All the Other Women}

Lovelace is an evil man. He kidnaps, then rapes Clarissa, and is justly punished when her cousin revenges her death in a duel with him. Yet Lovelace is never as bad as the women of the novel. Everywhere Clarissa turns she is met with unreliable and, often, vicious women. Although critics have read Clarissa's relationship with the men of the novel as an ideological Battle of the Sexes, these contests are never as violent, nor as heart-wrenching, as those between Clarissa and other women of the novel.

Aside from his exemplar, Clarissa, most of the women populating Richardson's imaginative world are little more than the men's stooges. ${ }^{31}$ Mired in egocentric desperation, they willingly give up the innocent and vulnerable Clarissa to her predator if 
it means they might snatch some semblance of agency. In fact, the novel can be read as the "bad" woman's teleological regress, inversely mirroring Clarissa's progress towards spiritual redemption. As Clarissa becomes more saint-like as the narrative progresses, the women she encounters become increasingly monstrous. As the materiality of Clarissa's body slowly gives way to its own supernatural ethereality, the "bad" women of the novel become gradually more mired in a carnality from which they cannot escape, which, in fact, they embrace. Significantly, the downward moral spiral of each of the novel's "bad" women parallels their decreasing class status. Yet as we examine the characterization of these women, we must remember that they all work to draw blame away from the much more violent behavior of male characters. The punishments handed down to Clarissa most often come from the ventriloquizing mouths of women; for each "bad" girl Clarissa confronts, there is first a male authorial figure whose power she must rival. In other words, when Clarissa threatens the authority of men or their rules, the danger posed by female independence and agency gets mapped onto female rivalry where it can be safely contained at the site of domesticity.

\section{Mrs. Harlow}

The first of the heterosexual rivalries to be displaced onto a conventional female rivalry occurs when what begins as the contest between Clarissa and her father for moral authority is played out largely as a struggle between Clarissa and her mother. Essentially orphaned when her entire family rejects her, it is her mother's rebuff that cuts deepest. Indeed, Clarissa is rarely confronted by her father. Rather, his mandates are handed down through his wife, who abandons her. Some critics have argued that the sudden 
popularity of the "orphan" trope in eighteenth-century fiction responds to an increasing number of abandoned children in England. ${ }^{32}$ Feminist critics, however, have blamed the trope on a more insidious ideological attempt to thwart woman's growth to maturity by denying her a matriarchal heritage. Marianne Hirsch, for example, has said, "The assumption is that even within patriarchy, women can be powerful if connected with each other" (44). Thus, mothers and daughters are separated, either by the finality of death or by an even greater impasse, the mother's unswerving allegiance to (or fear of) the father. Romantic heroines are plagued by absent mothers rather than deadbeat dads. In fact, were Mrs. Harlowe dead her failure to protect her daughter could be forgiven; it is her symbolic absence that unnerves the reader.

It is not enough, however, to understand Mrs. Harlowe as an abandoning mother, a passive cipher of patriarchal ideology. We must also see her as Clarissa's rival, a competing version of femininity. One might ask what we gain by reading Mrs. Harlow as such. Perhaps most importantly, we become more aware of the ways in which Richardson prevents Clarissa from openly confronting her father. The contest of wills, the ideological "battle of the sexes," although effective for reforming male bad behavior still represents a significant threat to male authority because it suggests the power a woman might wield. Thus, because Richardson cannot imagine Clarissa on equal footing with her father, he shifts the rivalry for authority onto the safer site of female relationships. The political dimension of gender conflict and the ideological possibilities opened up by a daughter willing to resist her father is defused by turning her rebellion into a question of competing versions of femininity. Asking which woman is the "right" 
kind of woman prevents the reader from asking instead what kinds of patriarchal control various versions of femininity work to uphold.

Mrs. Harlowe and Clarissa are, indeed, rival versions of femininity. The reader, if male, is urged to want a wife like Clarissa, not Mrs. Harlow; if female, she wants to be the daughter, not the mother. Further, while Clarissa and Harlowe compete for the readers' desire, they simultaneously compete for Mr. Harlowe's love. Both want to do what will please him most—but their strategies differ significantly. Mrs. Harlowe aims to please through unswerving, blind allegiance, and weakly "submits to be led" by her husband $(40)^{33}$. Her version of femininity is clearly "bad." Her greatest crime is that she does not do what comes "naturally," but allows others to choose for her. Repeatedly, Mrs. Harlowe sides against Clarissa, preferring the fantasy of a family united to one in which mothers and daughters are divided against fathers and sons. When Clarissa sends her mother letters, her mother responds by returning them, unopened. When at last Clarissa is raped and dying, Mrs. Harlowe resists sympathy, telling her she must "sail with the tide" of the family's continued anger (1154). In sum, Mrs. Harlowe has no will of her own—or, at least, refuses to enact it.

Clarissa routinely notes her mother's distress concerning this unswerving allegiance, and her daughter's identification of Mrs. Harlowe's grief is damning proof that Mrs. Harlowe represents a maternal failure. Her sin is made all the worse because she is a woman; cruelty is expected from men, not women. The novel implies that she should generally and innately empathize with the plight of women. She is, after all, the victim of an ideology that subjects her to her husband's will, so her readiness to subject 
Clarissa to a similarly loveless marriage with a similarly controlling man seems all the more cruel and unfeeling. She is not just a bad mother; she is a bad "woman."

Clarissa, however, wishes to earn her father's love and respect by proving to him that she can think for herself. She represents the enlightenment ideal of rational autonomy. She wants Mr. Harlowe to see that her refusal of Solmes, although against his initial wishes, is actually in his best interest. She is certainly staking out her own independence, a clear threat to paternal authority; however, by offering not to marry at all, she also implies her undying commitment to her father. The narrative suggests that Clarissa's act of disobedience is actually a greater proof of love than her mother's blind loyalty. Richardson thus sets mother against daughter in an intergenerational rivalry that will become typical of many conduct book-fictions of the time. But this is not to suggest that Richardson's agenda is feminist; in contrast, he simply replaces an older version of patriarchy with what Elizabeth Kowaleski-Wallace calls "new-style patriarchy." Gender codes are as rigidly enforced as ever, but daughterly compliance is attained through subtle coercion rather than force.

\section{Clarissa versus Arabella}

The tension of the novel begins with another kind of rivalry - that between Lovelace and James Harlowe. Their conflict allegorizes a certain kind of class warfare between the gentry, represented by James, and a corrupt aristocracy, represented by Lovelace. However, James' own corruptions spoil this allegory, so that the class battle

must be waged on the level of courtship. ${ }^{34}$ Yet even as Richardson pits Clarissa against 
Lovelace in a battle of the sexes, he also simultaneously shifts the weight of this contest onto that between Clarissa and other women—like Clarissa and Arabella.

Significantly, although James Harlowe is really the one to drive the wedge between Clarissa and her family, he interacts with Clarissa mostly through letters; rarely do they have face to face encounters. Instead, most of the struggles for power occur between James' female alter ego, Arabella, and Clarissa, and these exchanges are just as highly charged, if not more so, than that between Clarissa and her mother, or, more to the point, Clarissa and the men in her life. In fact, the narrative of sisterly rivalry is immediately introduced by Anna, who lets the reader in on the motives underlying Arabella's heinous behavior (40). Because Lovelace has courted her only to get closer to Clarissa, Arabella's pride is wounded; although she claims no preference for Lovelace, she does not want her sister to have him. Moreover, the narrative makes clear that Arabella's pathological jealousy is directed at punishing Clarissa for eliciting, however innocently, Lovelace's desire.

Lovelace is not the only one, nor is he the first, to abuse Clarissa verbally, physically, and mentally. However, the physical abuse Clarissa receives prior to Lovelace's cruelty comes at the hands of women. In one scene, Clarissa's stubborn refusals to submit to her family's requests angers Arabella so much that their feud becomes physical. Clarissa describes the encounter in a letter to Anna:

My sister is but this moment gone from me: she came up all in a flame, which obliged me abruptly to lay down my pen: she run to me- 
Oh spirit! Said she; tapping my neck a little too hard. And is it to come to this at last! Do you beat me, Bella?

Do you call this beating you? Only tapping your shoulder thus, said she; tapping again more gently--.... (228)

Clarissa's laying down of the pen when Arabella enters is significant, especially since moments later Arabella complains that Clarissa "has done enough with her pen" (228). Throughout the novel, the pen is used by Richardson to symbolize the moral authority of he or she who wields it. ${ }^{35}$ Clarissa's use of the pen is to narrate her complaints, to appeal to her readers' sympathies, and thereby encourage their moral reform. Bella, on the other hand, is intent on halting such communication; during this confrontation she even throws her handkerchief in front of Clarissa's mouth to stop her from talking. As Terry Castle notes, it is only the first of the many silencings experienced by Clarissa; what Castle doesn't note is that the novel tends to focus more generally on the ways women silence other women.

In addition to refusing to speak to Clarissa at various points in the novel, a predominantly feminine form of indirect aggression, the women of the novel consistently try to stop Clarissa from speaking. We know why Lovelace wants to interrupt her communication; he wants to maintain narrative control. Why, however, do women want to stop other women from telling their stories, from, perhaps, relating the pain experienced by all women to varying degrees in patriarchal society? The answer, according to social psychologists, is really quite simple: women, because of their subordinate position in society, wish to align themselves with men, not other women. In 
fact, in order to gain patriarchal approval, women may more eagerly exclude other women. Clarissa's violation of the norm, her resistance of patriarchal authority, is thus more readily punished by Arabella than by her father or brother.

Another reason why Arabella interferes with Clarissa's letter writing is because women are afraid of other women's "gossip"; while they might use gossip to enforce their own positions of power, they recognize the power of gossip as an exclusionary force. ${ }^{36}$ The "bad" women of the novel do not want Clarissa "gossiping" about them; Arabella does not want Clarissa to write to Anna about all the bad things she has done.

The conversation between Clarissa and her sister is also about how violence is understood. Subjected to men's cruelty, treated as chattel, poorly protected by the law, women have much at stake in the cultural understanding of violence. And yet over and again, women collude with a masculinist system. As studies have shown, they routinely blame the victim, even more so than men. ${ }^{37}$ They do so by reinterpreting violence. Bella pretends not to have hurt Clarissa, although Clarissa is both physically and emotionally pained. Her refusal to acknowledge Clarissa's distress as authentic will be repeated throughout the novel, as Clarissa's reality is consistently reconstructed by those around her. What is actually happening is always at odds with what is said or written about what is happening. The scene is indicative of what Castle recognizes as the discursive violence to which Clarissa is repeatedly subjected. ${ }^{38}$ Bella recreates Clarissa's experience; Clarissa is not being "beat" because Arabella says she is not. Her actions foreshadow the behavior of Lovelace who will later be unable to acknowledge the part he has played in Clarissa's death. Of course, such violent and insensitive behavior is more "natural" coming from a man, or so Clarissa repeatedly reminds the women around her. 
Bella, however, resists Clarissa's complaints. Says Chesler, girls learn "how to pretend, even to themselves, that they have not been aggressive, especially when they have been; or that they didn't really mean it and, therefore, it doesn't count, or that no serious harm resulted from what they didn't 'really' do" (126). Bella does not want to acknowledge Clarissa's accusations, so she stops up her mouth and redefines her actions.

She does, however, temporarily "tap" Clarissa more gently and resort to less direct methods of aggression—a verbal harangue, accusing Clarissa of destroying the family peace by refusing Solmes. Clarissa writes:

Thus she ran on, almost foaming with passion, till, quite out of patience, I said: No more of your violence, BellaHad I known in what a way you would come up, you should not have found my chamber door open!- - Talk to your servant in this manner: unlike you, as I bless God I am, I am nevertheless your sister-And let me tell you that I won't go tomorrow, nor next day, nor next day to thatexcept I be dragged away by your violence.

What! Not if your papa, or your mamma commands itgirl? Said she; intending another word, by her pause and manner, before it came out.

Let it come to that, Bella-then I shall know what to sayBut it shall be from either of their own mouths, if I do-not from yours, nor your Betty's.-And say another word to me, in this manner, and be the consequences what it may, I 
will force myself into their presence; and demand what I have done to be used thus!

Come along, child! Come along, meekness—-taking my hand and leading me towards the door-Demand it of them now...What! Does your heart fail you?_(for I resisted being thus insolently led and pulled my hand from her). I want not to be led, said I; and since I can plead your invitation, I will go; and was posting to the stairs, accordingly, in my passion—But she got between me and the door and shut it-. (228-29)

Clarissa continues to term Arabella's behavior "violent," whether a physical or verbal assault. She insists that Arabella recognize her own unnatural behavior. Finally exasperated by the ineffectiveness of indirect methods aimed to bully Clarissa into submission, Arabella turns again to physical aggression. She nearly curses at Clarissa, and angered when Clarissa points out her near mistake, tries to force her into descending the stairs. Unsisterly and certainly unladylike behavior, indeed.

But we must be careful to recognize how Richardson is constructing the text of female rivalry. Reading Clarissa as simply Arabella's victim would be misguided; Clarissa's cry of pain is simultaneously a construction of herself as victim, ${ }^{39}$ as she adopts a version of "proper" female aggression. Remember, she is writing to Anna, so the story she tells is entirely her construction. In fact, it is exactly the sort of story Arabella does not want her to circulate. Arabella's aggression is thus a direct response to Clarissa's indirect aggression, the threat of gossip. ${ }^{40}$ Because it is not socially acceptable 
to be physical with each other (a rule Bella seems to momentarily forget), Clarissa must find another way to hurt her rival. Instead, according to psychologist Natalie Angier, girls use "psychological tools of indirect, vengeful aggression, with the object of destroying the girl's position, her peace of mind, her right to be. Indirect aggression is... an... obsessive act in which the antagonist's soul, more than her body, must be got at, must be penetrated, must be nullified" (qtd. in Chesler 93). Girls turn to verbal aggression and social manipulation, gossiping about each other, excluding each other from activities, and deriding the intellectual inferiority of their rivals. We see Anna and Clarissa consistently talk about Arabella behind her back, and we sense that they have being doing so long before Arabella's jealousy over Lovelace. Arabella, it seems, has never quite fit in. She may even be a little jealous about Clarissa's and Anna's intimacy.

On closer examination, we can see that Clarissa has been depicted by Richardson as actively engaging in hostile, but indirect aggression against Bella who, like Mama Harlowe, represents a competing version of femininity. When Bella attacks her verbally, Clarissa remains cool and calm, pointing out Bella's improper behavior. She also, however, encourages Bella's violence. First she suggests the inappropriate level of intimacy Bella has with her chambermaid ("talk to your servant this way"), then reminds her of her unsisterly conduct, resists her demands, and finally suggests that she expects her to continue behaving badly. In essence, she is name-calling, too.

Further, their dialogue is really what one might now refer to as a game of chicken, in which Clarissa wins by forcing Arabella to recognize her own unnaturalness. Neither Clarissa nor Bella want Clarissa to obey Mr. or Mrs. Harlowe. If she does, then Bella will no longer be in the favored position. It is actually in Bella's best interest if Clarissa 
refuses to comply. However, Bella also knows that the way to insure Clarissa's continued resistance is to make her feel forced into a decision. When she pulls Clarissa to the stairs, she is bluffing. Similarly, Clarissa knows that Bella does not want her to go downstairs; when she strategically threatens to descend the stairs, she does so because she already knows Bella will try to stop her. Indeed, Arabella does get between Clarissa and the door. Clarissa's inaction is thus a form of indirect aggression which ultimately damns Arabella, no match in wits, to acts of physical aggression.

Eventually Clarissa retires into her closet to write, and when Arabella insists on staring at her through the glass, pulls the curtain. Even here, however, Clarissa is no victim (although she continues to construct herself as such). ${ }^{41}$ She shuns her sister, shutting her out of the closet, refusing to look at her, and finally drawing her curtain closed because she knows it "vexed [Arabella] to the heart" (229). Clarissa effectively cuts her to the soul.

Significantly, Arabella's venomous actions-- cornering Clarissa in her bedroom, forcing her to lay down her pen, physically assaulting her, and then forcing Clarissa to retreat into a coffin-like closet into which she peers like a voyeur, foreshadow not only Lovelace's misogynistic treatment of Clarissa after he kidnaps her, but perhaps more significantly, the sadistic behavior of the prostitutes of the Sinclair brothel. However, by committing these heinous acts first Arabella functions to deflect some of the blame for Clarissa's demise. In other words, Lovelace can never appear as fully "bad" as he should because Arabella has committed the first violence. Like the bad girls who will follow her, Arabella works to deflect the reader's anger so that Lovelace can remain, ultimately, a little loveable. Lady Bradshaigh, for example, admitted she could not "help being fond 
of Lovelace" (Correspondence 178). Richardson himself would lament, "Oh that I could not say, that I have met with more admirers of Lovelace than of Clarissa" and even revised the text in its second edition to make Lovelace more reprehensible. ${ }^{42}$ Yet despite his efforts, Lovelace never seems quite as bad as the women of the novel. Richardson reserves some authorial pity for Lovelace, but never for poor Arabella. ${ }^{43}$

What Richardson's reader should want, but which is not provided, is Arabella's complexity and the same sort of authorial attention that works to psychologize Lovelace's "bad behavior." While Lovelace is a man behaving badly, Arabella is simply bad. Among other attributes, Arabella is depicted as a gold-digger (42), vain (42), selfcomplacent and a faulty reader of Lovelace's intentions (43), bad tempered (43), and a coquet (44). She is jealous $(85,104)$ and heartless $(140)$. Arabella's treachery, moreover, is demonized more than that of Clarissa's brother by virtue of her gender. As a sister, she should empathize with Clarissa; as a woman, she too should resent a system that treats them both like chattel. Yet her selfishness and pride wipe out her ability to empathize (83). "Should not sisters be sisters to each other?" Clarissa complains to Anna, and yet Clarissa is able to assign Arabella's behavior to simple jealousy: "Her conduct, surely, can only be accounted for by the rage of a supposed rivalry" (230).

But female rivalry is never so simple, and to understand Arabella's behavior as the outcome of unrequited love is to overlook the facts of women's social subordination which underpin their hostile treatment of each other. Although Richardson clearly means to demonize Arabella in setting up a conventional good girl/bad girl dyad, a critical reader might be tempted to feel sorry for Arabella. After all, she has been cruelly slighted her entire life, yet Richardson glosses over the litany of her rejections. We 
know, for example, that in a world where woman's beauty is a precious commodity, she is sorely lacking in comparison to Clarissa. Anna says matter-of-factly, "what man of a great and clear estate would think of that elder sister while the younger were single?"

(68). Both Anna and Clarissa refer to Bella's unattractive plump face $(60,68)$ and Anna jokes of Bella's possible match with the heinous and hideous Solmes, "The woman...should excel the man in features; and where can she match so well for a foil?" (69). The irony of her name, Arabella, is all the more biting. As Luce Irigaray has famously asserted, women who are treated as commodities learn to view each other as rival commodities. Clarissa, as a rival commodity, is given unequal advantage, in both beauty and the estate she can offer.

Arabella is justly angered at having been slighted not only by Lovelace, but by her grandfather, who in leaving all his wealth to Clarissa, gives her an even greater social advantage. Clarissa can regret her grandfather's preference for her, lamenting that it has cost her family peace, but Arabella's own regrets at this preferential treatment are never taken seriously by Richardson. This seems odd, given the attention he pays to gender inequities. Yet clearly, all pity is reserved for Clarissa. The underlying narrative assumption is that only exemplary women deserve fair treatment. And it is Clarissa's exemplary moral status that positions her as an enemy to nearly all the other women of the novel, none of whom have the beauty or money with which to compete.

The result, of course, is that they tend collectively to bully her. Clarissa is deeply hurt by the unseemly alliance forged between Arabella and Mrs. Harlowe. Clarissa had always had her mother's preference, but once she rejects her mother's demands, she is alienated. Usurping her place, Arabella basks in the glow of the opportunity to be first 
choice. In turn, both Arabella and Mrs. Harlowe leave Clarissa out of their relationship, and use their alliance to bully the alienated Clarissa into changing her mind, dining together without her (106), or conspiring together in the parlour (113). Mrs. Harlowe, in fact, refuses to see Clarissa without Arabella present, although Clarissa reminds her of Arabella's resentments and insurmountable biases (113). Importantly, the pattern is one typical of female rivalry, as the two women push Clarissa to choose against what she knows is right. Her resistance, rather than being taken seriously, fuels the flame of their indignation. ${ }^{44}$ Clarissa experiences increasing aggression and decreasing sympathy from the men and women around her. Even her Mama ultimately becomes exasperated with her and refuses to see her. That these women believe they have the honor and wealth of their family at stake is no excuse; they are bullies nonetheless.

The fictional account of the women's bullying of Clarissa rings true of casestudies of real-life competition between women and girls, and says much about ways in which women aid and abet their own social oppression, taking out against each other frustration felt towards men and patriarchal society. However, I would not praise Richardson for his commitment to realism, or argue that Richardson intends to call attention to this misdirected anger in order to lament the absence of reliable female communities. Instead, Richardson naturalizes female competition, glossing over its root causes. Further, I argue that its depiction in the novel implies the dangerous power women, when united, possess. Female alliances threaten ideal femininity. The united front posed by Arabella and Mrs. Harlowe parallels and foreshadows a more unholy alliance between Mrs. Sinclair and her cronies, but it also resembles the friendship 
between Anna and Clarissa, which I will later argue Richardson similarly views as a “dangerous" partnership.

\section{Clarissa V. Betty Barnes}

The tension between Arabella and Clarissa is not fully played out, but once again, shifted downward, this time displaced onto a class dynamic. Arabella seemingly uses her

authority over her servant, Betty Barnes, to have her manipulate and spy on Clarissa. Yet what becomes clear is that the servant already possesses all sorts of "evil" ambitions. In many ways, Betty is a female version of Lovelace; in fact, Clarissa describes Barnes as her gaoless long before Lovelace becomes her new keeper (285). Barnes is a willing spy for Arabella, representing yet another one of those dangerous female alliances Lovelace, and implicitly Richardson, wish to sever. Most notably, Betty Barnes is power hungry, described as scheming to transgress class hierarchies in so far as she wields power over her prisoner, Clarissa (225). Clarissa says of Barnes, "[T]his creature has surprised me on many occasions with her smartness; for, since she has been employed in this controlling office, I have discovered a great deal of wit in her assurance, which I never suspected before" (225). Clarissa blames Arabella for giving to Barnes the authority to control her, and Clarissa is shocked by Barnes' "true" colors. Richardson suggests by this that Barnes has been performing the role of servitude that should come to her naturally; he insinuates that his readers should check the behavior of their own servants, lest they, too, harbor similar resentments.

In an obvious display of the abuses of authority in the hands of a lower-class woman, Barnes gleefully taunts Clarissa. Often, she is the messenger of ill-tidings. Says 
Clarissa of Betty's relayed news: "All this was the readier told me, because it was against me, and would tease and vex me" (257). In one scene, responding to Betty's abuses, Clarissa tells her sarcastically,

I am pretty well used to your freedoms, now, you know-I am not displeased in the main, to observe that were the succession of modern fine ladies to be extinct, it might be supplied by those from whom they place in the next rank to themselves, their chambermaids and confidants. Your young mistress has contributed a great deal to this quickness of yours. She always preferred your company to mine. As you pulled, she let go. (264)

Clarissa tells Betty that she knows she has been conspired against. Further, she suggests that Arabella, who might have profited by Clarissa's company, has instead been contaminated by Betty, whom she chose instead. The result is Betty's insolence and, more significantly, a precarious destabilization of rank and the natural order of things. Richardson makes the threat clear: insolent chambermaids, treated as equals, easily rise to the challenge of class hierarchy and either adopt the corrupt mannerisms of their mistresses or eagerly usurp their authority.

The rivalry between Clarissa and Betty for power becomes a battle of wits in which Clarissa's moral authority outmatches Betty's brute physicality and underhanded conniving. Clarissa effectively puts her in her place. Yet even Betty recognizes the strategy behind Clarissa's passive martyrdom, telling her, "Everybody takes notice, miss, that you can say very cutting things in a cool manner, and yet not call names..." (266). 
As with Arabella, Clarissa uses her discourse to cut to the heart of her opponent. And, like the other women of the novel, Betty works hard to stop Clarissa's mouth, repeatedly offering her food in the midst of their less than good-humored banter.

Barnes, like Sinclair later, works to displace the anger Clarissa and Anna, as well as Richardson's readers, might otherwise direct at the men. However, Barnes also works to redirect frustrations otherwise aimed at women of their own class. In other words, female rivalry works in this case to maintain the status quo of class hierarchy. One of these stereotypes on which the maintenance of class hierarchy depends is the depiction of working class women as threats to the heterosexual ideal. Significantly, Barnes is notably masculinized, for example, always pinching snuff. The masculinizing of lowerclass women occurs conventionally in domestic fiction. We see it also in Mrs. Sinclair, and in Pamela's Mrs. Jewkes, all of whom are a little too intimate with the other women of the novel for the eighteenth-century readers' comfort. ${ }^{45}$

The Sapphic impulses of lower-class women may perform an ideological task.

Susan Lanser has suggested that

in eighteenth-century western Europe the dominant screen distinguishing virtuous from Sapphic bodies may be that of class...[T]he imperatives of... a gentry class held in place a range of conventions dividing irreproachable female intimacies from dangerous ones and bifurcating friendship and sapphism along class lines. (184)

In other words, intimacies between women of the upper gentry, like the Ladies of Llangollen Vale, Eleanor Butler and Sarah Ponsonsby, were permissible, and even 
celebrated, while those involving working-class or corrupt aristocratic women were treated suspiciously. Explains Lanser, "Servants, tradewomen, and actresses were assumed to infect the worthier classes from 'below'; high aristocrats in debauched court cultures tempted virtuous gentry from 'above"' (186). Friendships between 'ladies" of the gentry thus work to support hegemonic interests, stabilizing class status by defining the gentry against the monstrous desires of women above and below it. Arabella, who has preferred an intimacy with a lower-class woman, effectively has been contaminated and has also put at risk a naturalized hierarchical social order. Hence Clarissa's repeated disdainful references to the intimacy shared between Arabella and Barnes.

\section{Clarissa versus Mrs. Sinclair and her cronies}

Betty Barnes, a chambermaid, is nevertheless safer than the other "monstrous" women of the novel. The worse insults are committed against Clarissa by those lower socio-economically. The violent physicality intimated, but never fully explored between Arabella and Clarissa is played fully out when these women participate in the rivalry. ${ }^{46}$

In a moment of terror duped by Betty Barnes and her lover into believing that the rest of the family is on her, Clarissa allows herself to be whisked away by Lovelace and taken to the Sinclair home. Mrs. Sinclair, he tells her, is the widow of a Colonel who now keeps a reputable inn. Lovelace assures Clarissa that her maid, Hannah, will soon be on her way; she must first recover from an illness. Meanwhile, Clarissa is given a waiting woman named Dorcas for a bedfellow. She is also introduced to Sally Martin and Polly Horton. Clarissa innately senses something is amiss, and does not wish to associate with the other women of the inn. She notes, for example, Sinclair's "strange sly 
eye" $(525)^{47}$ and complains, "At once, where I like, I mingle minds without reserve, encouraging reciprocal freedoms, and am forward to dissipate diffidences. But with these two young gentlewomen, I never can be intimate-I don't know why" (531). Clarissa's recognition that she should not "mingle" with these women is instinctual; while it is not based in explicit class prejudice, it is nevertheless striking that the women whose morality is immediately, visibly suspect are from the working class. As such, Clarissa suggests a natural inclination to associate with women of her class and with whom intimacy does not threaten mind and body. Class rivalry is, in this manner, naturalized.

Yet Clarissa nevertheless welcomes the refuge, in part because Lovelace has filled her closet full of books of which Clarissa approves; when she opens them she discovers the names of the women of the house written on the blank leaves (forged by Lovelace, of course) and believes that, because the books belong to them, they must not be so bad after all. On one level, Richardson suggests that women's reading habits are one way in which we can gauge their morality. However, he also questions this "evidence" as such advocating instead that readers trust to natural instincts that will help them judge the difference between the right kinds of women and all others.

Of course, we know from Lovelace's correspondence that Mrs. Sinclair's real name is Magdalen. Her name no doubt alludes to the biblical prostitute, Mary Magdalen; in fact, in 1758, nearly a decade after the publication of Clarissa, Magdalen Hospitals were founded to provide refuge and reformation to prostitutes. Magdalen's feigned name, Sinclair, can also be read as an inversion of Clarissa's name. The first half of Clarissa's name signifies clarity, brilliance; the second half, originating from the Egyptian, means "she who saves." Sinclair's name, however, is a corruption of the 
brilliant savior. She is brilliantly sinful, basking in the glow of her evil deeds. In fact, as Clarissa will later discover to her horror, Mrs. Sinclair runs a brothel and the women, Polly and Sally, whom she calls her nieces, and her "kinswoman" Dorcas, are actually prostitutes. An editorial interjection into one of Lovelace's letters to Belford tells us that Sally Martin and Polly Horton are "[c]reatures who, brought up too high for their fortunes, and to a taste of pleasure and the public diversions, had fallen an easy prey to his seducing arts..." (534). ${ }^{48}$ All of the women of the house collaborate with Lovelace to Clarissa's ruin. First, however, they must deceive her into believing they are her friends or, at least, have her best interests at heart.

At first, Lovelace enjoys what he believes is his devilish command of all the women. Lovelace writes to Belford to revel in Mrs. Sinclair's performance: [Y]ou'll be ready to laugh out, as I have often much ado to forbear, at the puritanical behavior of the mother before this lady. Not an oath, not a curse, nor the least free word escapes her lips. She minces in her gait. She prims up her horse-mouth. Her voice, which when she pleases, is the voice of thunder, is sunk into a humble whine. Her stiff hams, that have not been bent to civility for ten years past, are now limbered into curtsies three deep at every word. Her fat arms are crossed before her; and she can hardly be prevailed on to sit in the presence of my goddess. (537)

Just as earlier Betty Barnes had performed the part of respectful servant until her time came to gloat, here Mrs. Sinclair takes on the guise of a proper woman, the wife of a 
deceased Colonel, taking in lodgers out of necessity. Lovelace delights in her easy masquerade, and Richardson simultaneously suggests both the instability of appearance as a marker of class, as well as the threat lower-class pretensions pose to the gentry. Perhaps more significant, however, is the monstrosity barely contained by her performance; the excess of it threatens to burst the seams of her guise. Her mouth is a "horse" mouth, her arms are "fat," her legs "hams," and her voice like "thunder." Lovelace, and implicitly Richardson, delight in corsetting the power normatively held by this woman; now, in "puritanical" mode she is no longer "free" in her language, but "minces," "prims," "whines," and "curtsies." The joke is clearly not only on Clarissa, but on Sinclair, who mistakenly believes she possesses real agency. Yet as I will argue, the women are more than Lovelace's lackeys as they spy on Clarissa, relaying to him her habits and telling him where she hides her letters. In fact, as the novel progresses, we learn that it is they who call the shots, they who are depicted as most monstrous. Yet their desire to harm Clarissa is never complicated, never investigated; the narrative insinuates that they hate Clarissa simply because she is "good" and they are "bad."

In fact, so badly do the women of the Sinclair house want to bring Clarissa to their level, they urge Lovelace to rape her. Early on Lovelace tells Belford, "Sally, a little devil, often reproaches me with the slowness of my proceedings" (574). Later, when Clarissa refuses to dine with him, the exasperated Lovelace complains,

All the women set me hard to give her cause for this tyranny. They demonstrated, as well from the nature of the sex, as of the case, that I had nothing to hope for from my tameness, and could meet with no worse treatment were I 
to be guilty of the last offence. They urged me vehemently

to try at least what effect some greater familiarities that I

had ever used with her would have; and their arguments

being strengthened by my just resentments on the

discoveries I had made, I was resolved to take some

liberties.... (641)

What Lovelace explains to Belford is basically the nature of female rivalry. They turn on their own sex, suggesting to Lovelace that it is the "nature" of women to respond not to gentleness, but to force. They also excuse, a priori, the rape he intends to commit.

Clarissa, they advise him, will treat him poorly regardless of whether he is kind to her-so, he might as well rape her. Like Arabella, they reinterpret violence. Rape would not be violence, they suggest; in fact, if anyone is acting violently, it is the tyrant Clarissa.

Indeed, the women not only push Lovelace to rape her, but offer to help.

Eventually, if only temporarily, Clarissa consents to marry Lovelace, however, he still contemplates rape, and again writes to Belford of his dilemma:

Mrs. Sinclair and the nymphs are all of the opinion that I am now so much of a favourite, and have such a visible share of her confidence, and even in her affections, that I may do what I will, and plead violence of passion; which, they will have it, makes violence of action pardonable with their sex....and they all offer their helping hands. Why not? They say: has she not passed for my wife before them all?...They again urge me, since it is so difficult to make 
night my friend, to attempt in the day. They remind me that the situation of their house is such, that no noises can be heard out of it; and ridicule me for making it necessary for a lady to be undressed.. It was not always so with me, poor old man! Sally told me; saucily slinging her handkerchief in my face. (702)

Before, the women urged Lovelace to act because she could not be any angrier at him; here they suggest that he use her change in temperament to his advantage. Although earlier they had plead both her "case" and her "sex" to suggest Lovelace was in a no-win situation, now that he $i s$ winning, they continue to urge rape. Rape, they tell him, is pardonable if committed out of passion. As earlier noted, the women's blaming of the victim and their complicity in domestic violence are wide-spread phenomena, disclosing the internalization of their own oppression. The women of the Sinclair household continue to reframe Lovelace's violence as passion. They will even offer their "helping hands" if it makes the task easier.

While the novel's "bad" women work to reinterpret violence so, too, does Richardson work to reinterpret the reasons underlying their bad behavior. He secures the exemplary Clarissa in a house wherein she is surrounded by women who view her as a rival on multiple levels. A desirable woman who might tame a wandering man, she threatens their business. She is also a sexual rival; several of the women in the household who already have been used and discarded by Lovelace still desire him. Yet clearly, they are not good enough for him; they are fallen women. They hate Clarissa because her exemplary status reminds them that they will forever be barred not only from Lovelace's 
heart, but from social acceptance. They cannot be Clarissa; no one can. Instead, they must make her one of them. Yet while Richardson works hard to explain the women's bad behavior as rooted in these natural competitions, he tends to trivialize these rivalries, granting them no real merit. Ultimately, the bad women of the novel simply despise Clarissa's goodness.

Martin's motives, like Arabella's, are clearly framed by sexual jealousies. She says as much when, after offering to help Lovelace rape Clarissa, she throws her handkerchief at Lovelace, angry that he is patient with Clarissa when he was not so with her. Her spiteful behavior is described as "jealous revenge" (1053), and she even tells Clarissa that before she entered the picture, she had every hope that Lovelace might propose to her (1061). Not able to have Lovelace, she tends to act like him. Like Lovelace she wishes to control Clarissa's writing (1056) as well as her body, trying to force her to eat (1058). In another scene, Sally tries to tempt Clarissa to give up "the ridiculousness of prudery" (1056). Yet Clarissa resists the temptress as easily as Jesus resisted the Devil in the wilderness, a biblical allusion clearly implied here. Just as Arabella and Mrs. Harlowe assume the figure of tyranny so that the men controlling them become shadowy, distant figures so, too, does Sally Martin become the "real" jailer of Clarissa. Yet while Sally might have really loved Lovelace and have been genuinely duped by him, Richardson grants her no more sympathy than he did Arabella. She is a "bad" woman; implied is the obviousness of Lovelace's rejection of her. Who would want a Sally when one can have a Clarissa? But a critical reader should ask, what is a woman like Sally to do? Cheated out of her prized virtue by Lovelace (she even implies that she, too, had been raped), she can either choose to wither away like Clarissa or 
accept her devalued status and become a prostitute. Like Arabella, there are no alternatives for Sally. Yet the reader is not encouraged to feel badly for her.

To some extent, Richardson does complicate the women's competition with Clarissa by considering their class differences. It is clear that the women wish to knock Clarissa from her pedestal. In fact, when Clarissa first arrives at the house, Lovelace describes her arrival to Belford:

All sweetly serene and easy was the lovely brown and charming aspect of my goddess, on her descending to us; commanding reverence from every eye; a curtsy from every knee; and silence, awful silence, from every quivering lip. While she, armed with conscious worthiness and superiority, looked and behaved as an empress among her vassals. (534)

Lovelace, like Richardson, consistently works to exaggerate the class differences between Clarissa and the Sinclair women, routinely reminding them of her natural superiority. Notably, Clarissa is aware of her own superiority, not simply appearing better than they, but behaving as if they are beneath her. Surely such behavior speaks to her own class prejudices, but these biases are accepted as natural. The Sinclair women might be justifiably angry at being treated like "vassals"-but Richardson does not legitimate their anger.

Because the novel suggests that virtue is bound up in class status, to lose her virtue means Clarissa must necessarily fall—as have the women of the brothel. Thus, the narrative depicts them as earnestly working toward reducing her status—in much the 
same way Betty Barnes had worked to climb the social ladder. Both want to level class hierarchies, either by ascending to gentry status, or forcing Clarissa to descend to theirs. Lovelace acknowledges "[Mrs. Sinclair] and Sally are extremely pressing with me, to leave the perverse beauty to their breaking, as they call it, for four or five days" (906). When the women complain to Lovelace of his patience with the "perverse beauty," they insist angrily, "The methods taken with her have augmented her glory and her pride" (943); they despise that she has used her trials to adopt martyrdom, and wish to see her pride deflated. After her rape, they goad her about her impoverished situation, reveling that they now have in their power the "haughty beauty, who kept them all at such a distance" (1054). They nickname her "Haughty-airs" and tell her, "Pride will have a fall" (1056). They also tease her about her appearance: “'Methinks, miss,' said Sally, 'you are a little soily, to what we have seen of you. Pity such a nice lady should not have changes of apparel"' (1058). The women clearly envy her higher social status, not only her ability to buy nice clothes but the social respect which comes with what those nice clothes signify. Her adversaries delight in the notion that Clarissa, appearing a little "soily" now, might at first glance be difficult to distinguish from her moral and social inferiors.

Moreover, the rivalry with Clarissa is also suggested to be economic. When she believes that a repentant Lovelace will convince Clarissa to marry him, Mrs. Sinclair fumes that his "example will be followed by all [his] friends and companions — as the old one says, to the utter ruin of her poor house" (1074). Richardson's implication is clear--if men marry women like Clarissa, they will no longer need brothels; they will be entirely satisfied with their wives. Moreover, their desire will be converted from a sexual to moral economy. It is an economy Richardson desires, but one within which Mrs. Sinclair 
simply cannot operate. And yet in what economy can Mrs. Sinclair operate? A widow lacking a real source of income, like the women whom she manages, she has few alternatives. She can decide that she cares about neither money nor sex (as does Clarissa); this would be the "good" thing to do. She could choose to die and play the part of martyr widow. But clearly Sinclair feels empowered, however illusory that power. It is, in fact, both her economic and social power which both Lovelace and Richardson wish to end.

As with all the other women, Richardson alludes to but does not fully elucidate the reasons underlying Sinclair's choices; to do so would undermine his project to naturalize Clarissa's goodness. Instead, although he implies that the women's sadistic behavior towards Clarissa is not entirely unfounded, he nevertheless tends to trivialize it as the result of natural rivalries. In fact, as Koehler suggests, Richardson uses these bad women to control the message of his text; they represent the unwanted "noise," the interpretations or other narratives which he wishes to exclude. For example, "Anna excludes the 'noise' of Arabella's 'unsisterly' behavior... by providing an authoritative (and unflattering) interpretation of its 'secret motive,' envious love for Lovelace” (160). Her behavior is thus never investigated. Similarly, the 'noise' of the prostitutes 'bad' behavior is excluded; by rejecting their untold stories, by writing them off as 'noise,' Richardson makes sure that readers interpret them (and Clarissa) as he wishes. The questions which their noise might elicit, questions I am asking here, are silenced as effectively as Clarissa.

The overdetermined ubiquity of female rivalry and ready female rivals makes Lovelace's (and hence Richardson's) job much easier. Not only does Richardson depend 
heavily on a highly conventionalized good girl/bad girl dyad, he also relies on assumptions about women's inherently catty natures. Lovelace over and again uses the "given" of female jealousy to manipulate Clarissa. When Clarissa temporarily gets away from the Sinclair household, Lovelace relies on the trope of jealousy to draw her back in. He plays into what Richardson depicts as inherent insecurities in the gullible Mrs. Moore and Miss Rawlins, whom are harboring a disguised Clarissa. Concocting a sly story, he tells the two women that Clarissa is a jealous wife, who having erroneously suspected him of infidelity, has “eloped" from him (764). He is conscious of women's supposed eagerness to better each other, especially if they feel threatened by a woman much younger and prettier than they. Thus, he suggests to them, "Women who had lived some time in the world, knew better than to encourage such skittish pranks in young wives" (780). He invokes a hierarchy of age to gloss over the notion that the older women are more than happy to help him out if it means putting the beautiful and young Clarissa in her place. Moreover, Lovelace knows that the women will believe Clarissa is a jealous wife; the narrative suggests that all women inherently are, and that all women expect each other to behave jealously. Additionally, Lovelace reinterprets Clarissa's fear as skittishness, and his own violent behavior as husbandly impatience. Here, too, the women are eager to blame the victim; but the narrative suggests that Lovelace is already well aware of women's tendency to side with men against other women, and to concoct narratives that work to justify domestic violence.

In another cunning move, and in order to "prepare them in favour against whatever might come from Miss Howe," Lovelace depicts Anna as a female rake who does not have Clarissa's best interests at heart. Again, he depends on the trope of female 
rivalry, and as he relates the scene to Belford explains, "although I did not directly aver, that she would rather have had me; yet they all immediately imagined that that was the ground of her animosity to me, and of her envy to my beloved; and it was pity, they said, that so fine a young lady did not see through such a pretended friend" (800). In other words, Lovelace plays into assumptions the women already possess about female rivalry to aid his plot. Richardson implies that women are ready and willing to believe the worst of each other, and to commit, without further investigation, the greatest atrocities against each other under cover of feigned sympathies. Once again, because of women's complicity with male misogyny, Clarissa finds herself Lovelace's captive.

\section{Clarissa versus Anna? With friends like these, who needs enemies?}

Anna would seem to be the one safe haven of female intimacy in the novel. Their friendship is a source of comfort for Clarissa; Anna seems to be only person, male or female, on whom Clarissa can count, a woman with whom she does not have to compete. Yet arguably, the two do compete, over their interpretations of Clarissa's desire for Lovelace and, ultimately, the two represent competing versions of femininity. Anna's urging Clarissa to marry Lovelace suggests that she, herself, may desire Lovelace. It is odd that despite all of Lovelace's rakish behavior, and against Clarissa's complaints, that Anna consistently urges her to marry him. Anna's love for Clarissa may be genuine, as may be her attempts to rescue her, but her own moral weaknesses mean that, ultimately, she fails Clarissa. For example, she cannot control her anger and writes nasty letters to Arabella, the result of which is to aggravate the already irritated family (1120). We know, too, that she is a gossip $(39,67,85)$ and a manipulator who likes to provoke others 
by her own resistance_-for example, refusing Hickman because her mother likes him.

We know also that, in a Lovelacian manner, she would also like to control Clarissa in so far as she wishes to "own" her story (53). Anna, though better than the other women of the novel, is finally a "bad" version of femininity. She is too much aware of her power, too unwilling to give up her authority to her superiors, either a parent or a husband. She is, in sum, far too feisty.

Anna may also represent another kind of anxiety for Richardson. Primarily she fails as Clarissa's friend by insisting that their friendship take primacy over all other relationships. Their friendship rings of highly charged homoerotic desire, perhaps another anxiety experienced by Richardson and motive for him to instill into all female friendship a level of distrust lest it turn into a less "innocent" form of intimacy. For example, Anna calls Clarissa her first/primary "delight" $(53,549,1114)$ and asks Clarissa, "Would either of us marry, if the fellows and our friends would let us alone? " (277). She also terms Clarissa the "true partner of my heart" (1114). Routinely, she raves against the institution of marriage, saying at one point, "all men are monkeys more or less,...that you and I should have such baboons as these to choose out of is a mortifying thing, my dear" (210). She despises men $(133,134,210)$, prefers the single life $(213,277,1456)$, is more than willing to give Hickman up (207), and revels in her power over him (274). She also repeatedly offers to take Lovelace's place, asking Clarissa, "Whether you choose not rather to go off with one of your own sex; with our Anna Howe - than with one of the other; with Mr. Lovelace?" (356). When Clarissa dies, Anna throws herself on her coffin, kissing the dead body, and cries "I loved the dear 
creature as never woman loved another" (1403). Their intimacy, a form of romantic friendship, always seems ready to cross over into the homoerotic.

Nor are Anna's feelings unreciprocated. Clarissa, too, makes clear over and again that she has no preference for any man and repeatedly offers to live single and never marry $(72,95,110,149,281)$. Her desire is a clear impediment to her "safe" enclosure within marriage. Even Mrs. Norton has noted of their relationship that "no third love can come in between" (131). Lovelace's presence, then, is as an intrusive third, attempting to redirect Clarissa's desire away from Anna and toward himself. Yet he is consistently frustrated, as has been every man before him, and as Clarissa promises, so will every man be after him.

In turn, Lovelace consistently works to intervene in the friendships of the women; he clearly wishes to control their discourse. ${ }^{49}$ He says he "dread[s] the correspondence between the two young ladies... who would not wish to be able to twirl them round his finger" (416). Later, he worries (rightly) about the "consequences [which] might follow this undutiful correspondence" which has "long made me uneasy" (554). He schemes to control their letters and to forge Anna's correspondences because he recognizes the subversive potential of female intimacy. Certainly, Lovelace's interruption of Clarissa's letters parallels Richardson's editorial voice as he interjects himself into her letters, as well as picks and chooses which letters to 'enclose.'

Richardson also uses the trope of female rivalry to disrupt this female intimacy which he perceives as threatening the heterosexual paradigm. He must cast even this friendship as implicitly rivalrous and, moreover, dangerous. Lisa Moore suggests that “[i]f the modern subject was 'first and foremost a woman,' in Armstrong's terms, and the 
founding category of modern subjectivity was sexuality, as Foucault argues, then the sexuality of the bourgeois woman came under intense cultural pressure in the late eighteenth-century..." (3). However, I think in Clarissa, especially in Clarissa's relationships with other women, we can see this same cultural pressure at work much earlier. Although some have argued that romantic friendship was rarely questioned, Moore has argued that eighteenth-century literature demonstrates a tangible uneasiness about homoerotic impulses evidenced in women's friendships. ${ }^{50}$ She asserts that conduct-book fiction consistently worked to disarm threatening homosocial intimacies: "The sexual Other of the virtuous bourgeois woman is often her slightly Sapphic female friend" who "provides the heroine with the opportunity to risk and then refuse sexual immorality" (12). Clarissa must learn that, as a competing version of femininity, Anna is simply no match for herself. In the end, she must leave Anna behind and claim her own exemplary but alienated status.

Ultimately, it is Lovelace's forcing of Clarissa into his heterosexual vision, through the rape, that Clarissa rejects Anna. Following the rape, she tells her that they must wean themselves from each other: "I am not what I was when we were inseparable lovers, as I may say—Our views must now be different—Resolve, my dear, to make a worthy man happy, because a worthy man must make you so" (1088). On one hand, Clarissa is anticipating her own death, therefore suggesting that Anna must choose a substitute love-- Hickman. The narrative implies that Clarissa's farewell to Anna, however imposed by circumstance, is nevertheless appropriate. Lovelace has had to force it on her, but so has Richardson in so far as he dictates her transformation as an outcome of rape. 
The homoerotic nature of their friendship is emphasized again after Clarissa's death, and once again Richardson uses the narrative to redirect Clarissa's desire. Clarissa bequeaths a picture of Anna, previously worn on her bosom, to Hickman, but not before kissing it passionately (1357)_-insinuating the transfer of Anna from the homoerotic threat to the heterosexual ideal. In other words, Clarissa's death works to bring together Anna and Hickman. Significantly, Mr. Belford writes to Lovelace on Clarissa's death, that "her fervent love...for her Miss Howe...[has] given way to supremer fervours" (1364). In other words, Clarissa's death enables the appropriation and chastening of a homoerotic desire by a spiritual economy.

Especially in Anna's marriage to Hickman we can see an alignment of Lovelace and Richardson. The very fact that Anna winds up with Hickman seems Richardson's version of poetic justice. Although Hickman is supposedly a "good" man, Richardson has allowed Lovelace consistently to make fun of him (1091-92). In fact, Lovelace suggests Hickman as a punishment for Anna. Says Lovelace, "I had once thought of revenging myself on that little vixen... But, I think—let me see-yes, I think, I will let this Hickman have her safe and entire..." (1149). But Lovelace's desire to see Anna and Hickman together, clearly a misogynistic plot aimed to thwart Anna's agency, is identical with Richardson's vision. Anna is, in fact, willed to Hickman. Watt says that Lovelace's plan to rape Anna and her mother, although abandoned, "suggests a willing co-operation on the part of his creator's far beyond the call of literary duty...[it is] a monstrously gratuitous fancy which is quite unnecessary so far as the realisation of Richardson's didactic intentions are concerned" (235-36). I suggest that in Anna's marriage to Hickman we see a displacement of Richardson's "gratuitous fancy"-Anna is not raped 
by Lovelace, but she is married to a "dud," and therein effectively punished. In fact, if Richardson's didactic intention is to preach against the dangers of female intimacy as he works through anxieties about women's increasing agency, then Anna's marriage is quite necessary to this masculinist plot.

Richardson discloses these anxieties not only in this particular union, but in his characters' authoritative views of female friendship. Near the novel's close, the Colonel writes to Belford claiming, "Friendship, generally speaking...is too fervent a flame for female minds to manage....Marriage, which is the highest state of friendship, generally absorbs the most vehement friendships of female to female..." (1449). ${ }^{51}$ Yet it would seem that Richardson doth protest too much. The Colonel's need to assert this claim in the face of Richardson's authorial decision first to kill off Clarissa, and then marry off Anna, smacks of masculinist anxieties about the threat of female community and homosocial intimacy.

\section{Richardson's Rescue of Lovelace}

Ian Watt suggests of Richardson, "There was probably a much deeper identification with his rake than he knew" (235). Many critics have since, and quite rightly, noted parallels between Richardson and Lovelace, some even going so far as to try to redeem Lovelace as a romantic hero. ${ }^{52}$ Because Richardson identifies so closely with his rake, he must, to some extent, rescue him. While all the women of the novel share responsibility for Clarissa's tragedy, nevertheless, it is the prostitutes who Richardson holds centrally responsible. Their treatment of Clarissa is the most physically violent, the most unsympathetic. Sociological studies of competition among prostitutes 
have suggested that their aggression against other women tends to be more physically violent than that of competition between non-prostitutes. The same is true of poor women. ${ }^{53}$ Yet Richardson's depiction is less remarkable for its accurate depiction of brothel life than what I see as his attempt to use these women to redirect the readers' anger. Richardson clearly demonstrates that the readers should be less angry at Lovelace than the women who spur him on. Thus, while in reality competition between women works to displace frustration about their social oppression by men, in Clarissa the narrative replicates this displacement, urging Richardson's ample female readership to blame other women rather than men for Clarissa's tragedy. It is in asserting this blame that we most readily see the fusing of Richardson and Lovelace.

When the threat of fire in the next apartment forces a half-dressed Clarissa into Lovelace's arms, the discovery that the fire may have been a false alarm designed by the other women of the house enrages Clarissa. She locks herself into her room and refuses to come out. Lovelace writes to Belford,

By my troth, Jack, I am half ashamed to see the women below, as my fair one can be to see me. I have not yet opened my door, that I may not be obtruded on by them. After all, what devils may one make of the sex! To what a height of - what shall I call it? — must those of it be arrived, who once loved a man with so much distinction as both Polly and Sally loved me, and yet can have got so much above the pangs of jealousy, so much above the mortifying reflections that arise from dividing and sharing with new 
objects, the affections of him they prefer to all others, as to wish for, and promote a competitorship in his love, and make their supreme delight consist in reducing other to their level!-For thou canst not imagine how even Sally Martin rejoiced last night in the thought that the lady's hour was approaching. (729)

Love lace berates the very women he has consigned to do his dirty work, displacing his own guilt onto what he sees as an innate fault in the sex. He is baffled by their willingness to give Clarissa up to him, although both Polly and Sally claim to love him. He wonders how their possessiveness has turned into an eager desire to see other women's virtue destroyed. In fact, he disowns his own part in promoting their “competitorship.” Arguably, Richardson implicitly blames Lovelace for harnessing their unrequited desire to support his own gain; when he exclaims, "What devils may one make of their sex" he might suggest his complicity in turning them into devils. However, I argue that the sex to which he refers is ambiguous; he implies that they have made a devil of him, and that their malleability, envious natures, and easy ability to turn the focus of their desire to Clarissa is suggested to be inherent in women.

Later, having lost the ground he had gained with Clarissa, Lovelace again turns to blame the women of the house:

Devil fetch them, they pretend to know their own sex. Sally was a woman well educated—Polly also—Both have read—both have sense—of parentage not contemptible— once modest both—still they say they had been modest, but 
for me-not entirely indelicate now; ...The old one, too, a

woman of family, though thus (from bad inclination, as

well as at first from low circumstance) miserably sunk-

And hence they all pretend to remember what once they

were; and vouch for the inclinations and hypocrisy of the

whole sex; and wish for nothing so ardently as that I will

leave the perverse lady [Clarissa] to their management

while I am gone to Berkshire; ... [They are] continually

boasting of the many perverse creatures whom they have

obliged to draw in their traces. (940)

Lovelace begins by privileging his understanding of femininity over theirs; although they are women, he has a more sophisticated working knowledge of womanhood than they. It is a claim that Richardson may have reiterated as he routinely rejected the advice of his female readers as he drafted the work. Here, too, Lovelace makes clear that the evils to which the women have sunk are not owing to natural class tendencies; after all, all were once of respectable classes. However, having sunk morally they, like wayward shepherdesses, wish to increase their fold. Lovelace positions himself as better able to recognize virtue in others, and ironically, as Clarissa's would-be protector.

Female rivalry, as it turns out, represents something of an enigma; it can take on a life of its own. Lovelace laments, "These cursed women are full of cruelty and enterprise. She will never be easy with them in my absence. They will have provocation and pretence therefore... The two nymphs will have jealous rage to goad them on—and what withhold a jealous and already ruined woman?" (940). Even Lovelace admits he 
cannot control the very women he has seduced into helping him in his plot. Their desire runs rampant and cannot be harnessed; thus, they are a far greater threat to Clarissa's well-being. In fact, Lovelace suggests that as much as his ploys depend on female rivalry, jealous women are also dangerous to him because, as he notes, they are not always loyal women. A jealous sister nearly ruined at least one of his love affairs in France, even though he had initially used the sister's jealousy to advance his schemes (674-75) and he notes, too, that he fears Clarissa's friendships with the women in the Sinclair household because "jealousy in woman is not to be concealed from woman. And Sally has no command of herself"' (535). In other words, a jealous woman is initially easy to manipulate, but ultimately difficult to control. Jealousy easily backfires. It is best simply to keep all women, whether enemies or friends, from each other.

Thus, Lovelace constructs himself as having been controlled by the women all along, duped into believing he was in control, when in reality they were his puppeteers. He says to Belford, "In this situation; the women ready to assist; and, if I proceeded not, as ready to ridicule me; what had I left but to pursue the concerted scheme...?" (947). They give him no choice; he must rape Clarissa. Continuing, he implies that it is women's gossip and deceptions which mislead men like him: "Sally, the last time I was with her, had the confidence to hint that, when a wife, some other person would not find half the difficulty that I had found...[I]f a man gives himself up to the company of these devils, they never let him rest till he either suspect or hate his wife" (941). Later he says, "The cursed women, indeed, endeavored to excite my vengeance, and my pride, by preaching to me eternally her doubts, her want of love, and her contempt of me" (1482). Women's jealousy thus infects men, who might otherwise trust women. Women, he 
implies, are the root causes of men's mistreatment of their wives. These women's gleeful derision of other women ensnares even Lovelace, the hunter.

In fact, the reader is increasingly encouraged to read the interactions between Lovelace and the Sinclair household as a race to see who can ruin Clarissa first. The prostitutes' desire that Lovelace rape Clarissa implies their own desire to possess her. At one point, Lovelace implicitly fears that to spite him, Sally may work on Clarissa to give up her virtue to another man (or woman!) in his absence. Together, Belford, Lovelace, and Richardson as editor combine forces to dehumanize and demonize the prostitutes as the real destroyers of Clarissa. After raping Clarissa, Lovelace blames Mrs. Sinclair for her misbehavior saying, "that a mischief which would end in simple robbery among menrogues, becomes murder if a woman be in it" (896). He insinuates that they have worsened the crime; but he foreshadows the end result. Although he has only intended to "rob" Clarissa of her virtue, she will die because he has involved the women, her female rivals. Later, he says of their bullying of Clarissa that it is "a scurvy villany (which none but wretches of [Clarissa's] own sex could have been guilty of" (1084) ${ }^{54} \mathrm{He}$ deflects blame for his own actions by reminding not only himself and Belford, but also his readers of the women's evil natures.

One might argue that Lovelace's comments are ironic; that he refuses to recognize his own misdeeds. However, the women are similarly blamed by Belford, arguably the "good" guy of the novel because he is able to register horror at Clarissa's plight. Indeed, as testament to his increasingly lucid perspective on truth, Clarissa entrusts her story to him. His comments about the women are thus indicative of Richardson's views. Belford refers to Martin as a sadistic vulture "with the entrails of its prey on its rapacious talons" 
(1053). Lovelace never appears so monstrous. "Insolent Devils!” Belford cries of the prostitutes, "How much more cruel and insulting are bad women, even than bad men!" As the narrative voice of authority, he consistently works to redeem Lovelace-depicting him as weak, vulnerable, and therein excusable-- by means of implicit contrast with the bad women.

Perhaps no where more damning to the prostitutes is the description of Sinclair's deathbed scene, narrated by Belford. Here, Mrs. Sinclair can no longer control the excesses of her body, which burst through its corpulent seams. Belford describes the gruesome scene:

Her misfortune has not at all sunk but rather, as I thought, increased her flesh; rage and violence perhaps swelling her muscly features. Behold her then, spreading the whole tumbled bed with her huge quaggy carcase;: her mill-post arms held up, her broad hands clenched with violence; her big eyes goggling and flaming-red as we may supposed those of a salamander; her matted grizzly hair made irreverence by her wickedness (her clouted head-dress being half off) spread about her fat ears and brawny neck; her livid lips parched, and working violently; her broad chin in a convulsive motion; her wide mouth by reason of the contraction of her forehead (which seemed to be halflost in its own frightful furrows) splitting her face, as it were, into two parts; and her huge tongue hideously rolling 
in it; heaving, puffing as if for breath, her bellows-shaped

and various-coloured breasts ascending by turns to her chin

and descending out of sight with the violence of her

gaspings. (1388)

Mrs. Sinclair's deathbed scene is the strongest example of the ways in which bad women are flattened into archetypal creatures. In fact, A 1691 poem called "The Female FireShips. A Satyr Against Whoring" calls to mind Richardson's depiction of the Sinclair prostitutes, as well as Belford's final unveiling of their true nature in Sinclair's deathbed scene. The poem might very well have supplied Richardson his ammunition:

Women indeed to outward view they seem,

But are their Sexes scandal, blot and shame;

Like Angels they may seem in Dress, and meen,

But could you view the frightful Fiend within,

Who whets their lewd desires, and eggs them on,

To act those Mischiefs they too oft have done. (qtd. in

Bradford 48)

The reader might think immediately of Sinclair's "puritanical" behavior when she first meets Clarissa, or of the other women's attempts to befriend her and engage her trust. Moreover, the prostitutes of the poem, even in old age, do not "extinguish lustful Fire;/ Like Sparks rakt up in Embers 'tmay return,/In fury, and with rage and Passion Burn" (qtd. in Bradford 50). What is so disturbing to Belford is that with their make-up removed, the women look old. Belford describes the unmasked women surrounding the dying Sinclair as "(unpadded, shoulder-bent, pallid-lipped, feeble-jointed wretches) 
appearing from a blooming nineteen or twenty perhaps overnight, haggard well-worn strumpets of thirty-eight or forty" (1388). He continues, "it is evident that as a neat and clean woman must be an angel of a creature, so a sluttish one is the impurest animal in nature" (1388). While it would seem that the reader would need no further evidence of these women's corruption, the narrative nevertheless turns to expose them further in what is a conventional degradation of women's souls by their bodies. Their behavior is ugly, so they must really look ugly. Further, we see that their evils are compounded; they are bad for hurting Clarissa—but here they are depicted as even worse for deceiving men.

The smeared make-up and various states of undress and dishevelment of the women surrounding Sinclair in this scene clearly call to mind Swift's dressing room (1387-88). ${ }^{55}$ Brenda Bean, however, has astutely argued that Swift's poem satirizes the male spectator for "ludicrous disillusionment" concerning the idealization of femininity (6). Whereas Swift tries to help the reader see the world anew and to recognize his interpretative skills as faulty, Bean says Richardson rebuilds faulty idealizations: "Richardson (through Belford) records moral outrage at the depth of woman's treason to standards of female virtue. Belford's purpose in this passage is to provide a lesson (ostensibly for Lovelace) on the bestial characters of fallen women and the dangers that men risk in associating with them" (9). In other words, Richardson uses the bodies of bad women to educate readers; he needs the bad girls to compete against and lose to his vision of ideal femininity. He needs them, too, to clear men's names. They, not the men, are the real danger. Bradford Mudge, in his analysis of literary representations of prostitutes, explains that the poem cited above implies that "[a]lthough they 'seem' to be women and although they look like 'Angels,' they are in reality seductive imposters, 
beguiling fictions more dangerous to men than ghosts, wars, cannibals, or deserts" (48). Belford is amazed to see the women as he had never seen them, "unprepared for being seen" (1388). Even Lovelace seems to discover this about the prostitutes as they become increasingly difficult for him to control; the narrative implies that while the male rake thinks he can manipulate the bad women, in the end he is the one manipulated by them. As both he and Belford lament over and again, bad men are never as bad as bad women. Mudge notes that prostitution and masquerades are often inextricably linked. He cites letters submitted to The Spectator in the first half of the eighteenth-century complaining of various "sisterhood[s] of coquets" at masquerades bent on leading naïve men to their falls. Writes Mudge of one man's account of meeting with a female "coxcomb":

As with Adam and Eve, she who tempts is more culpable than he who falls; for regardless of his obvious failings, the writer remains a sympathetic character haplessly victimized by a professional siren. His transgressions pale in comparison to hers because his desire, however immature, is utterly conventional and so can assume itself simple and honest; It is as it appears. Her desire, on the other hand, is mysterious and deceiving; She is not as she appears. She is a dangerous and beguiling 'fiction,' an imposter motivated by money rather than love, self interest rather than affection for or attraction to her prey. (35) 
Like Sinclair and her cronies, the woman in this anecdote is far more reprehensible than the male coxcomb; in fact, while his desire is excused as natural hers, because motivated both by money rather than love is monstrous. Mudge explains,

A character of brazen impropriety, the prostitute sold her body in an action that for early eighteenth-century Britons epitomized two irreconcilable qualities: the passionate nature of women and the commercial calculation of men.

Because she makes passion her business, however, the prostitute could never be considered a 'real' woman. Real women were selfless (or supposed to be) even in their pleasures. (47)

Mudge notes the reformist movement between 1700 and 1750 to do away with prostitution, ${ }^{56}$ but that by 1750 the tide had changed to privilege efforts to reform prostitutes and sanitize literature. ${ }^{57}$ Among others, says Mudge, "Samuel Richardson and Sarah Scott tried to rehabilitate the novel by offering moral alternatives to salacious popular fiction" (48). One might argue that Richardson offers Clarissa to these women as a moral alternative, one which they reject. Yet Clarissa's very exemplarity excludes her as a realistic model. None of these women can hope to be a Clarissa. There would exist no place in society for these women, except perhaps for the Magdalen society wherein they would still be cut off from the rest of the world. Even this "refuge," however, is not offered to these women; instead, they all die painful deaths.

However, it is not only through Belford and Lovelace that Richardson condemns the women. The narrative, too, depicts them as little more than caricatures of evil. 
Maddened by Clarissa's escape, Sinclair threatens bloody violence against the negligent maid who let her escape, sounding very much like a wicked old witch from Grimms fairytales: “[M]ake up a roaring fire-the cleaver bring me this instant-I'll cut her into quarters with my own hands; and carbonade and broil the traitress for a feast to all the dogs and cats in the neighbourhood; and eat the first slice of the toad myself, without salt or pepper" (968). Sinclair is hideously frightening, a direct contrast to Lovelace who is always a little bit charming. Further, we know that Sinclair is in the room with Lovelace when he rapes Clarissa. In fact, it is she who drugs Clarissa, then helps to hold her down. Her face is the last thing Clarissa remembers seeing before she is raped. Who is to say that it is not she who has raped Clarissa?

In turn, Clarissa is afterwards demonstrably more afraid of Sinclair than Lovelace. She condemns the women even more harshly than Belford or Lovelace when she writes to Lovelace urging his protection from the prostitute: "But, good now, Lovelace, don't set Mrs Sinclair on me again!...She so affrights me when I see her...don't let her bluster up with her worse than mannish airs to me again! Oh she is a frightful woman! If she be a woman" (894). Sinclair's Sapphic impulses, making explicit those insinuated by Betty Barnes, are even more frightening than the rapist Lovelace. In fact, Mrs. Sinclair's behavior resembles that of a dominatrix, a role which Laura Hinton has argued is closely linked to male sadomasochistic fantasies. ${ }^{58}$ Even as Richardson condemns Sinclair, he also seems to delight in narrating a homoerotic fantasy within which Sinclair rapes and ruins Clarissa. Nor is this the first time Richardson has used a masculinized woman to physically assist a rape; we see this too when Mrs. Jewkes holds Pamela down for Mr. B. Richardson seems to enjoy displacing men's crime onto the bodies of bad women. ${ }^{59}$ 
Yet while the narrative works to demonize the prostitutes, it is their own selfcondemnation that is most damning. At Sinclair's death, Sally is forced to admit of herself and Mrs. Sinclair to Lovelace that Clarissa's "ruin was owing more to their own instigations than even [savage as thou art] to thy own vileness" (1378). Sinclair concurs, "For though it was that wicked man's fault that ever she was in my house, yet it was mine, and yours, and yours, and yours, devils as we all were (turning to Sally, to Polly, and to one or two more), that he did not do her justice!" (1389). The conclusion notes, too, that Arabella blames her miserable marriage on poetic justice for her mistreatment of her sister. However, that the women are willing to take on the blame, to recognize their own unnatural behavior, does not work to gain the reader's sympathy. After all, the women are not repenting. They are only acknowledging their own vileness and owning their monstrosity. They are affirming what Lovelace, Belford, Clarissa, and ultimately Richardson, have already insinuated: that women are the root cause of all evil.

Clarissa, ultimately, is not a real woman. But while she performs a clear ideological function, the novel demonstrates that Richardson does not so easily maintain clear boundaries between his good girl and bad girls. As Tassie Gwilliam notes, "Even though subdividing women into whores and saints may allow Richardson to recirculate and scapegoat negative feminine qualities in the service of exalting the pure woman, the danger remains that the outcast group may taint the exalted one because of ineradicable resemblances between them and her" (89-90). She argues that the need to demarcate these boundaries becomes a pivotal concern of the text. Thus, Clarissa must become Christ-like, removed from reality. 
In fact, as Koehler notes, in his correspondences Richardson insinuates that he does not expect any ordinary woman can attain Clarissa's stature. While Richardson suggests Clarissa is a good model for women readers to follow, "he also communicates the sense that what we admire in her is defined by what she surpasses in all other women. In effect, he attempts to instill in his readers a desire...[which] reinforces masculine privilege..." (Koehler 169). Clarissa's exemplarity is maintained only by Richardson's steady belief that women cannot be like her. His dependence on a good girl/bad girl rivalry thus works to insinuate that all real women are, at heart, "bad"- - and can be exposed as such when contrasted with the feminine ideal.

Indeed, it is in his best interest if this ideal is not achieved. What would the world do if it were to be populated by Clarissas, smarter, wittier, and more moral than men? Arguably, some of Richardson's concerns about Clarissa's potential to rival male authority creep into Lovelace's rhetoric:

What would become of the peace of the world, if all women should take it into their heads to follow her example? What a fine time of it would the heads of families have? Their wives always filling their ears with their confessions; their daughters with theirs: sisters would be every day setting their brothers about cutting of throats, if they had at heart the honour of their families, as it is called; and the whole world would either be a scene of confusion, or cuckoldom must be as much the fashion as it is in Lithuania. (1149) 
Lovelace's fears are legitimate, and evidenced by Richardson who does not allow Clarissa to reform Lovelace in her lifetime. Arguably, to avoid total chaos, Richardson must write her death. Yet he uses the good girl/bad girl dyad to maintain the masculinist belief that there are, indeed, no good girls. This belief, in turn, works to justify male privilege and control.

\section{Conclusion:}

\section{Sisters in Iniquity: Richardson, Women Writers, and Literary Rivalry}

The ideological work performed by Richardson's characterization of the brothel workers is more insidious than simply a conventional replication of a good girl/bad girl binary, or general concerns about the threat inherent in female friendship and community. The narrative also functions to both displace his anxieties about women writers as well as insinuate the problems inherent in women's creative power. As my introduction has detailed, the eighteenth-century literary field is riddled by anxieties felt by male writers who found themselves suddenly competing with women for authorial control. The threat symbolized by writing women is crucial to understanding the signification of Richardson's depiction of not only the prostitutes, but of women who read and write.

As noted by several critics, women readers in the text are routinely exposed as faulty interpreters. ${ }^{60}$ As Castle has argued, Clarissa herself is a bad reader who must recognize that her interpretation of the world is in conflict with others'. Some have suggested that the drive of the novel is to get Clarissa to lay down her pen. But there are other women in the text who are also bad readers. Mrs. Harlowe is a bad reader, misinterpreting her daughter's motives time and again $(89,112)$. While Clarissa insists 
that she does not desire Lovelace, Mrs. Harlowe refuses to accept her story. Arabella, too, treats Clarissa badly because she has misread her as a sexual rival. Both hear only the story offered up by James and Mr. Harlowe, even in the face of all evidence that proves otherwise. Anna Howe is also a bad reader. Over and again, against Clarissa's protests, she insists that Clarissa really does love Lovelace, and that she should marry him $(70,71$, $135,173,248)$. Of course, one could argue that Anna correctly reads Clarissa's desire; after all, to some extent, Clarissa acknowledges Anna's suspicions as accurate when she admits Anna knows her better than herself. Yet what Anna more importantly misreads/misunderstands is Clarissa's commitment not to act on these feelings and the social and moral consequences if she does; instead, Anna seems committed to changing Clarissa's mind. In fact, she says that she could he lp Clarissa if Clarissa would only marry Lovelace $(224,335)$, even after he rapes her! $(1043,1045)$. Further, Anna is depicted as encouraging Clarissa to edit the truth $(73,1043)$. She confirms Richardson's logic that female readers look on, but judge events incorrectly, and therefore cannot accurately write them. The narrative thus works to remove Anna's writing and interpretative opportunities. In her will, Clarissa bequeaths her letters to Anna, and just as she desires that her body will be only handled by women (1413), so, too, does she ask that her letters—-her textual body—-be edited only by Anna. However, Richardson takes control of this exchange as Clarissa's editor.

Although Richardson condemns women's reading and editing skills through the characters of Mama Harlowe, Arabella, and Anna, it is his depiction of the prostitutes as symbolic of women writers which is most scathing. In my introduction I cited an excerpt 
from Modern Poets (1791) comparing women writers to a coven of witches. It is helpful to quote it again here:

See Phoebus trembling on th' Aonian hill

The clamorous Fair surround-en dishabille;

Like flocks of geese Saint Michael's day that bless,

Not less their numbers, nor their cackling less.

What troops of Druidesses now assail,

Their meteor-hair streams around their visage pale, All grim with snuff their nose, and black their length of nail. (qtd. in Lonsdale xxvii)

The prostitutes are routinely referred to as witches and devils, but the poem above rings especially true for Belford's depiction of the prostitutes who stand around Sinclair's deathbed. He says of them,

There were no less than eight of her cursed daughters surrounding her bed when I entered...[who] seemed to have been but just up, risen perhaps from their customers in the fore-house, and their nocturnal orgies, with faces, three or four of them, that had run, the paint lying in streaky seams not half blowzed off, discovering coarse wrinkled skins: the hair of some of them of divers colours, obliged to the blacklead comb where black was affected...that of others plaistered with old and powder...but every one's 
hanging about her ears and neck in broken curls, or ragged ends...

[T] hese were the veterans, the chosen band; for now and then flitted in, to the number of half a dozen or more, by turns subordinate sinners, undergraduates, younger than some of the chosen phalanx,...stretching, as if from the unworn effects of the midnight revel; all armed in succession with supplies of cordials, of which every one present was either taster or partaker under the direction of the Praetorian Dorcas.... (1387-88)

Even when not explicitly termed witches or devils, their very appearance betrays their evil allegiance. Their faces, the disarray of their hair, and their "flitting" about ghostlike aligns them with the misogynist depiction of women writers as witches in Modern Poets. That they are passing around cordials reminds us of the "intoxicating potion" Sinclair administered to Clarissa when she was kidnapped and raped (949). Dorcas, here, is heralded as the leader of the evil band of midnight revelers or orgy-goers; they might as well be devil-worshipers as they crowd around the braying Sinclair.

Mudge notes that although fears about women's sexuality are nothing new, in the early eighteenth-century they emerge as linked to images of financial control: "Middleclass women's involvement in the literary marketplace thus constituted an activity associated at once with illicit pleasure and economic gain" (87). The conflation of writing with prostitution was a common eighteenth-century rhetorical trope. According to Catherine Gallagher, writers like Aphra Behn and Delarivier Manley, who early in their 
careers wrote about female passion, were able to exploit the conflation of women writers' sale of their texts with that of their bodies. By the mid-eighteenth-century, however, women writers were feeling the pressure of the stigma associated with women writers. The Astrea/Orinda dichotomy which pitted "lascivious" writer Behn against the more appropriately sentimental Katherine Philips best represents the sort of ideological dilemma faced by women writers. To gain social acceptance as a woman writer, women had to reject and look on as a rival their female literary predecessors. ${ }^{61}$

If Richardson perceived his female contemporaries as a threat, which I argue he does, then the next logical step is to read Mrs. Sinclair and her cronies as allegories for literary women. Their fictions are pitted against his—-while not entirely opposed to a woman writer, he nevertheless fears their contaminative power. He must rescue Clarissa from their house. She must return to her Father's house. She must receive her Father's blessing. In turn, the fictions produced by the prostitutes must be unmasked, denounced, and, ultimately, discarded.

If, indeed, Mrs. Sinclair reminds us of the cannibalistic witch in Hansel and Gretel, then it's into the fire she herself should go. Lovelace, exasperated with their aggression against Clarissa, cries to Belford,

damn the whole brood, dragon and serpents, by the hour...The great devil fly away with them all, one by one, through the roofs of their own cursed houses, and dash them to pieces against the tops of chimneys, as he flies; and let the lesser devils collect their scattered scraps, and bag them up, in order to put them together again in their allotted 
place, in the element of fire, with cements of molten lead.

Their "scraps" are sent to the fire, burned into nonexistence. These might be the "scraps" of their dismembered bodies, or it might be the "scraps" of writing they represent.

I want to suggest further, however, that these scraps serve a larger symbolic purpose. If, as I have argued following Koehler, Richardson's intention is to drown out the "noise" of these other women, then the scraps he wishes to burn are the stories they would otherwise tell—the stories I have tried to tell here. Just as Clarissa's scraps of disorganized, chaotic, nonsensical poems and musings written following her rape are dismissed by Lovelace, the "bad" girls' metonymic scraps are similarly figured as incoherent and worthless. But if we could recover these scraps and piece them together, I think what we would find is something very much like what I have tried to piece together here: the real stories of women's oppression and of the reasons, uglier than anything Belford could have imagined, underlying women's hostility toward each other. 


\section{Chapter Two:}

\section{Utopic Sorority?: Female Rivalry and Revision in Sarah Scott's Millenium Hall (1762)}

A little more than a decade following the publication of Clarissa, Sarah Scott published her feminocentric, utopian novel, Millenium Hall (1762). Like the novels of other female authors following in the wake of Richardson, Scott's work evidences a trenchant ideological struggle to make sense of her literary inheritance. ${ }^{62}$ Richardson's misogynistic depiction of female communities, and in particular, of female friendship must have weighed heavily on her mind as she sketched out her female governed, and predominantly female inhabited, Arcadia. While much has been written about Scott's depiction of romantic female friendship, critics have not yet considered the significance of Scott's portrayal of female rivalry. Many have read the utopia as a refuge from bad marriages and bad men; but in overlooking the role "bad" women play in these women's flight from society, these arguments overlook a significant ideological concern addressed by the novel. ${ }^{63}$ I suggest that the Arcadia is an escape from bad women and the novel a feminist critique of the conditions which create their "badness."

In this chapter, I argue that Scott returns to the problems raised by Richardson concerning an oppressive patrilineal system which treats women like chattel, but revises the misogynist turns that Richardson's novel takes. As I have argued, Richardson's narrative implies that the only utopia for women exists in heaven, and that while they live in the world, they must reject its dangers, including those inherent in female friendship. While Scott rescues female friendship, making it the basis of an earthly utopia, her 
terrestrial paradise also depends on a resistance to the conventional trope of female rivalry. Millenium Hall provides a counterexample to a tradition of "realistic" fiction which warns against the inevitability of female rivalry.

Because it is an idealization and therefore fraught with ideological contradictions, Scott's utopia ultimately cannot offer up a successful model of female friendship nor a reliable alternative to heteronormativity. However, while I want to address the problems of her utopia, I first want to examine the ways in which Scott attempts to respond to a masculinist literary tradition, revising both its form and narrative content. While the feminist potential of the novel is undercut by the problems inherent in utopian fiction, Scott also resists at least one of the traps of idealized sorority: some women, like men, are bad - but their badness is a condition of their social circumstance, not inherent in femininity. Further, Scott proposes in place of conventional female rivalries a healthy model of female competition productive for all of society.

\section{Avoiding Rivalry, Resisting Form}

Despite Richardson's tremendous influence on the shape of the eighteenthcentury novel, Millenium Hall resists the Richardsonian model on several levels. Most obvious of these is its form. Unlike the epistolary tradition established by Richardson, Millenium Hall is a fictional frame narrative, organized around several inset tales, each of which focus on the experiences of individual women. These stories are first narrated by a long-time inhabitant, Mrs. Maynard, and then re-told by her cousin, Sir George, who relates them to a friend in letter form. This friend then publishes them. Thus, although the novel begins as a letter between two men, this exterior frame soon vanishes, allowing 
the inset narratives centrality. Critics have offered plausible explanations for Scott's choice. Dorice Williams Elliott suggests that the framing letter form Scott chooses is not necessarily linked to Richardsonian epistolarity, but rather "a common form that philanthropic discourse assumed in the eighteenth century-the public letter" (538). Hence, Scott's vision of feminine philanthropy appropriates what had been a predominantly male tradition. ${ }^{64}$ Additionally, Gary Kelly suggests that "Scott turned her back on the Richardsonian revolution in prose fiction, apparently finding that it embodied a transmuted and disguised form of courtly ga llantry" ("Bluestocking" 173). Scott's utopian plan, he argues, is like other eighteenth-century utopias, based in a critique of court culture. Elsewhere he notes that the form she chooses is in keeping with preRichardsonian models (“Introduction" 20). However, while Kelly identifies Scott's strong links to the Bluestocking circle, he does not consider that the earlier prose forms Scott works with are largely written by women.

Rather than writing within the masculine tradition established by Richardson, Scott looked instead to his female predecessors. Scott would have most certainly been thinking of a maternal literary heritage which included writers like Margaret Cavendish, Delarivier Manley, Catharine Trotter, Mary Carleton, Mary Davys, Aphra Behn, Eliza Haywood, and Jane Barker (not to mention a host of French and Spanish authors translated into English and wildly popular in seventeenth and eighteenth-century British circles). All of these women writers appropriated the framed novella form, characterized by inset narratives, to interrogate patriarchal ideology ${ }^{65}$ Because of the form's inherently subversive tendencies, women were drawn to it to combat misogynist practices. Many of the case histories presented in these frame novels involve the experiences of women 
suffering from abusive marriages or those who have been deceived out of their innocence by men who then desert them. The framed novel used these experiences to encourage readers to "test the case," in other words to judge for themselves whether the women were really moral criminals or instead victims of a misogynistic society.

Relying heavily on Bahktin's account of the novel, Josephine Donovan argues that the framed novel is much more dialogic than the 'modern novel.' She explains, "the inherent structural tension between the inset stories and the frame commentary sets up a dialogical potential in the framed novella that is eclipsed in the novel, where the narrative focus is more unified" (31). These inset stories help to decenter "monolithic ideological forms" (Donovan 31) and recognize a diversity of voices without subordinating them, as the modern novel does, to a single, unifying voice. In the framed novella, often "no one voice dominates, and no voices are dominated" (Donovan 32). In other words, all stories are given equal attention, and no overarching interpretative authority is established to manipulate the readers' perspective. The reader must decide who is really at fault. In contrast, while Richardson's epistolary form enables us to hear several voices as well, his editorial interjections tend to dominate the readers' interpretations and, as I have argued, lead them to side with some characters more than others. ${ }^{66}$

Although Mrs. Maynard narrates many of the stories in Millenim Hall, no single story is emphasized. The frame narrative precludes the women's competition for centrality. No lone voice emerges as the novel's heroine or exemplar. Critics have not yet addressed the important positioning of Mrs. Maynard, who tends to fade into the background of their arguments, yet I argue the she maintains a central importance, specifically in Scott's revision of the tropes of female rivalry. Testament to Scott's 
genius, Mrs. Maynard does not tell her own story, not because her own story lacks importance but because if she were to share her experience, as central narrator, she would detract from the stories of the other women. Her story would risk overshadowing the others narratively, potentially insinuating that her's was the story by which the others should be judged. Instead, she, like Sir George, is never really part of the story. While both may offer interpretations, (Mrs. Maynard's always the more instructive and implicitly the more insightful) ${ }^{67}$ their interjections act tangentially. In effect, the women's stories collectively assume equally weighted importance.

Perhaps even more significant is the fact that Mrs. Maynard relates the stories to Sir George, rather than having each of the women telling their own stories. This narrative strategy is further evidence of Scott's resistance to female rivalry. Because Mrs. Maynard relates the stories, the women never vye with each other for Sir George's greater sympathy or desire. Sir George never becomes a potential lover potentially seduced by hearing the trials and tribulations of a beautiful woman. Scott prevents him, in other words, from becoming a Mr. Hintman (one of the women's rakish guardians) or, worse, a Lovelace. In contrast, because Clarissa writes to Lovelace, she invites his desire; she must do so in order to attempt to reform him. ${ }^{68}$ Scott, however, does not employ her female characters in the service of such masculinist ideology; they do not use their beauty or sexual desirability to reform their male visitors. In fact, neither Sir George nor Lamont ever really interact with these women except to ask questions; thus, the romance plot that positions women as rivals is effectively cut short, channeled in another direction. The women are not inviting the spectators' desire. They have, we know, had enough of "romance." 
Indeed, the women even appear disinterested in using their own life stories to elevate the readers' impression of them. They do not fancy themselves exemplars—as we know from Richardson, the status of an exemplar is particularly lonely. Linda Dunne has noted that, in this respect, Millenium Hall is a revision of the restrictive model of eighteenth-century heroinism. She suggests that before the women enter the utopian community, that they have separate lives and stories; however, inside the community this individuality melts into a communal sense of identity-evident, Dunne argues, in the homonymic sounds of their names (64-65). The women's focus is not on their past, in which they each lived distinct and isolated lives, but on their present and future, celebrating mutual experience and accomplishment. This mutualism precludes a masculinist conception of female exemplarity, the defining component of good $\mathrm{girl} / \mathrm{bad}$ girl binaries.

There is yet another way in which the form of the novel contributes to Scott's revision of Richardson's model of female rivalry. Donovan argues that the framed novella is partly rooted in a pre-capitalist gift economy in which stories were circulated orally like gifts. Says Donovan of the framed novella, "Its oral conversational style is...a 'gift giving' mode; that is, it involves a collaborative literary production and a free exchange of ideas on a given topic. No one 'owns' the topic as property; it remains in circulation in a kind of open-ended process. It does not become alienable as a commodity is reified in a market economy" (33). Of course, as argued by several critics, even a "gift economy" entails obligation; ${ }^{69}$ Scott's nostalgia for such an economy is no doubt problematic. However, I am less interested in whether gift-economies were more or less oppressive than capitalist economies. Instead, I suggest that what we see at work 
is Scott's idealization of such a society, her belief in the possibility of a utopic form of exchange. The women of her story have been treated as property, exchanged between men, alienated from their own bodies, positioned against each other as rival commodities. ${ }^{70}$ For Scott, a gift economy suggests the possibility, however idealized, of resisting such "ownership."

Donovan has suggested that the Richardsonian model established a long tradition of sentimentalist fiction which tended to depict the female protagonist as a passive victim; thus, the "inherent social satire and anti-romantic bent" of earlier women's writing was "largely overshadowed by the dominant sentimentalist genre" (121). Nevertheless, says Donovan, the anti-romance inheritance continued throughout the eighteenth-century and is evidenced in the works of Sarah Fielding, Charlotte Lennox and Maria Edgeworth. I would add to that list Sarah Scott's Millenium Hall. Many reasons underlie Scott's choice of the framed-nouvelle form. It establishes her work in a long history of feminist standpoint fiction written by women. Further, she resists the domination of the women's voices by a central dominating voice. In doing so she sets at tension the stories of the women and those of the men's (especially Lamont, who like Richardson and Lovelace, insistently interrupts the women's stories), but grants the women's stories and Mrs. Maynard's brief interpretations of those stories greater authority. Finally, Scott's choice of a genre rooted in a gift economy not only mirrors the gift economy produced by the women at Millenium Hall, but also arguably suggests a desire to resist the alienation and reification inherent in a market economy, which she knows too well. ${ }^{71}$ 


\section{Re-directing the Content of Good Girl/Bad Girl Binaries}

Many have read Sarah Scott's utopian project as inherently conservative, a rejection of the more radical feminist projects of the women preceding her. Janet Todd, for example, suggests that Millenium Hall is emblematic of the eighteenth-century's progressively pious ideologies and greater restrictions on women writers. Says Todd, “The fictional separatist communities tinged with lesbianism and hedonism in Manley's works or the outspokenly celibate and intellectual one imagined by Astell gave way to gentler communities of victimized women coming together to perform charitable functions" (115). In this respect, one could argue that Scott is implicated in a politically charged contest with her literary mothers over the "right" version of femininity; to this extent, because the version of femininity she champions is often used to bolster patriarchy and to denounce the separatist feminism of earlier models of female community, contemporary feminists have tended to label her project "conservative."

However, while no doubt a less "radical" version of female community, Scott's novel is nevertheless a revision of masculine versions of proper femininity. Todd notes an important change in novels written by women following Richardson; while Richardson may have demonized prostitutes early in the century, later female writers rescue women otherwise viewed as unredeemable. Says Todd, as the century progressed "humanitarian sentiment increased, [and] there was a desire to see prostitutes—a group which often included simply 'fallen' women or women living with men outside matrimony—not as professional women but as victims of society in need of help and encouragement to reform" (116). She notes the formation of the Magdalen hospital as evidence of this change. ${ }^{72}$ Although Scott's narrative does not include the voices of these 
sorts of "fallen" women, her treatment of women in general is far kinder and compassionate than Richardson's. Further, her treatment of "fallen" women is in line with another feminist revision noted by Todd. Todd explains that while Richardson's efforts at social criticism end in the death of his heroine, later women writers would more often rely instead on "female friendship, defense and comfort in a hostile male world" (143). We certainly see this change in Scott's novel; where Anna had over and again failed Clarissa, and where other women plotted together against her, the women of Millenium Hall routinely rescue each other. While some "bad" women populate the narrative, the novel's drive is either to avoid or transform traditional models of female rivalry.

The rules at Millenium Hall clearly work to discourage female rivalry. When a new woman arrives she is directed to deliver any money she has into a community fund (although if she leaves she may be repaid). "The great design of this," explains Mrs. Maynard, is "to preserve an exact equality between them" (116). In this way, women avoid competing with each other over who has the richer equipage, or even over who has contributed the most to the house's financial success. To maintain this equality is another rule: "Each person shall alternately, a week at a time, preside at the table, and give what family orders may be requisite" (116). No one woman is left in charge; the threat of tyrannical matriarchs disappears. ${ }^{73}$ While the rules also ask that the women dress plainly, they are not required to dress uniformly (116). In this way, difference is encouraged while avoiding the possibility that women will compete with each other on the basis of physical appearance. A respect for their differences further is emphasized by the encouragement of their individual talents. All are urged to pursue the occupation in 
which they excel, whether sewing, painting, gardening, cooking (118). While these all are clearly "feminine" pursuits, no one woman is expected to excel in every category. Moreover, if a woman wishes to follow "mental pursuits" she is likewise encouraged (118); no doubt, the implication here is that she may choose to read, write, or philosophize as she desires.

Importantly, no one who might encourage female rivalry can stay; if a woman should "by turbulence or pettishness of temper, disturb the society, it shall be in the power of the rest of them to expel her" (117). Yet even this woman's expulsion is democratic: "a majority of three parts of the community being for the expulsion, and this to be performed by balloting" (117). If one grows tired of the company of others, one does not have to feign interest. While all are required to assemble at specific occasions (meals and prayer), "no one is obliged to stay a minute longer in company than she chuses" (119). In this way, the rules of the house, while working to minimize compulsion, also function to guard against the sorts of female rivalries to which the women have been exposed in the outside world.

These rivalries are, in fact, the subject of many of the case histories which make up the narrative. Like her female predecessors, Scott uses the frame narrative to challenge the social rules dictated to women concerning proper behavior and desire. In particular, all of the women's stories put to the test marriage and courtship, as well as conduct-book advice generally known to warn against the impossibility of maintaining strong female intimacies after marriage. ${ }^{74}$ Scott's Millenium Hall is deeply invested in revising the myths of female rivalry circulated by "realistic" fiction; hence, the stories which her women tell consistently resist the conventional plots which pit women against 
each other. Female rivals are treated sympathetically. Moreover, where the reader might expect a female friendship to be either precluded or dissolved by rivalry, he/she is routinely surprised by the intensity of the women's commitment to each other.

The first female friendship described occurs between Louisa Mancel and Miss Melvyn (later Mrs. Morgan). Miss Mancel's history seems entirely conventional. Mysteriously abandoned by her parents as an infant, she is left to the care of an aunt. When the aunt dies (in a tragically sentimental scene), the beautiful and eerily wise child attracts the attention of Mr. Hintman, who appears a generous benefactor willing to assume parental responsibilities. He sends her to be educated at a boarding school, where another student, Miss Melvyn, befriends her.

Miss Melvyn's story is equally tragic. The daughter of wealthy aristocrats, she is devastated when her mother dies. Her father, Sir Charles, a weak-minded man, remarries and his new wife, a cunning and envious woman, possesses all the attributes of a conventional wicked stepmother. The new Lady Melvyn convinces Sir Charles to send his daughter away to boarding school, and effectively prevents most visitation between father and daughter.

While I want to return to talk about Scott's portrayal of the wicked stepmother, I first want to concentrate on the potential for female rivalry between Miss Mancel and Miss Melvyn. Mr. Hintman, a wealthy, handsome, and seemingly good-hearted man, visits often and fondly bestows gifts on not only Louisa but all of her friends. He clearly appears a "good catch" for either of the girls when they reach an appropriate age. Yet no romantic interest develops on the girls' part; both tend to think of him as a father-figure. Nor, as his symbolic daughters, do they compete for either his attention or his generosity. 
In fact, when Louisa routinely refuses his gifts of money, Mr. Hintman, rather than bestowing them on her friends, encourages her to be the benefactor. In this manner, he grants to her agency; no doubt Louisa wields authentic power in a houseful of young girls in which she can choose whom to make happy. Yet we never see the other girls fighting for Louisa's attention either. Instead, we see the bonds between Louisa and Miss Melvyn strengthen.

In fact, Miss Melvyn attempts to refuse Louisa's generosity, fearing that acceptance of such gifts might contaminate their otherwise flawless friendship:

Miss Melvyn was void of that pride which often conceals itself under the name of spirit and greatness of soul; and makes people averse to receiving an obligation, because they feel themselves too proud to be grateful, and think that to be obliged implies an inferiority which their pride cannot support. Had Louisa been of the same age with herself, she would have felt a kind of property in all she possessed; friendship, the tenure by which she held it; for where hearts are strictly united, she had no notion of any distinction in things of less importance, the adventitious goods of fortune. The boundaries and barriers raised by those two watchful and suspicious ene mies, Meum and Tuum, were in her opinion broke down by true friendship; and all property laid in one undistinguished common; but to accept Miss Mancel's money, especially in so great a proportion, 
appeared to her like taking advantage of her youth; and as she did not think her sufficient judge of the value of it, she did not look on her as capable of being a party in so perfect a friendship, as was requisite to constitute that unity of property. (93)

While Miss Melvyn believes that a perfect friendship can share property without inviting jealousy or resentment, she fears that Louisa is too young to understand either the value of the money she wishes to share or the value of the friendship that Miss Melvyn wishes to protect. This scene is crucial because it suggests the inherent dilemmas women face in a capitalist economy which values private property. Within a masculinist economy, women cannot be true friends; much too dependent for survival on money (and the men who possess it), they will always be positioned as rivals. As Luce Irigaray has argued, because social order depends on men's exchange of women, women's value is entirely dependent on male desire. Hence, "[i]t is out of the question for them to go to 'market' on their own, enjoy their own worth among themselves, speak to each other, desire each other, free from the control seller-buyer-consumer subjects. And the interests of businessmen require that commodities relate to each other as rivals" (Irigaray 196). ${ }^{75}$ But Miss Mancel and Miss Melvyn are not rivals, and are prevented from becoming so by Scott's belief in the power of female friendship to transform value. As noted by George Haggerty, Scott's utopia "is a challenge to every assumption about the position of women in eighteenth-century society, where they themselves become property in a male system of exchange" ("Romantic" 113). The women of Millenium Hall refuse to see each other as property and reject the rules of exchange. 
Of course, Miss Mancel and Miss Melvyn are only able to do so because Hintman has created for the two women a unique situation. Confined within the boarding school, enabled to use the money as she desires, Louisa possesses the opportunity to transform it from private to communal property. The money she offers to Miss Melvyn is altered by the women's greater desire for female friendship so that rather than conferring power on the individual who possesses it, the community of female friendship is empowered. It is this power which concerns Miss Melvyn; she fears the sense of obligation which the terms of gift-giving imply.

However, Miss Melvyn also believes that a perfect friendship can transform the terms of gift-giving so that the sense of reciprocity created binds the women in a positive and balanced relationship. Helene Cixous has suggested of such relationships, "all the difference lies in the why and how of the gift, in the values that the giver draws from the gift and the use to which he or she puts it" (159). She imagines a utopia much like that created by Scott which "will change the rules of the old game" (Cixous 169). Irigaray, too, considers the potential for women to change these rules, asking:

But what if these 'commodities' refused to go to 'market'? What if they maintained 'another' kind of commerce, among themselves?

Exchanges without identifiable terms, without accounts, without ends?...Use and exchange would be indistinguishable....Nature's resources would be expended without depletion, exchanged without labor, freely given, 
exempt from masculine transactions: enjoyment without a

fee, well-being without pain, pleasure without possession.

Utopia? Perhaps.... (197)

Has Scott imagined such a utopia? One within which women have indeed "refused to go to market"? Louisa, young, unassuming, gives selflessly, expecting nothing in return; she changes the rules of the game. She and Miss Melvyn propose a new economy rooted in female intimacy and communal property. As noted earlier, this is not to say that such a potential actually exists. As Zizek has discussed, utopia is a fiction that works in the service of the hegemony. I will discuss later the symbolic power wielded by these women of the middle and upper ranks, and the sorts of labor they solicit as a form of payment from those women beneath them. Here, however, what is significant for my argument is not whether Scott's plan is blindly idealistic, but that she has a plan at all, that she sees the necessity for reform and that reform necessarily involves revising the rivalrous roles women normally enact with each other.

There has been a convincing critical push to read the Arcadia at Millenium Hall not as an escape, which would position the women as passive victims, but as a conscious choice, a refusal of the terms of patriarchy. ${ }^{76}$ In refusing marriage, and in rejecting the terms of a masculinist gift exchange, Miss Mancel and Miss Melvyn revise the social contract. Rather than depending on the exchange of women as property, rather than viewing each other as rival commodities, the women propose a society within which women exchange pleasure (and money) freely among each other.

Meanwhile, the world outside Millenium Hall continues to be populated by rivalrous women. The conventional good girl/bad girl binary is therein converted to a 
new relationship: female community vs. rivalry. The flatness of both good and bad girls is complicated by a consideration of their circumstance and, further, by their potential to move fluidly between categories. Women may choose to enter or leave the community. No one is fixed as either good or bad, and in this way Scott rejects what Richardson had imagined as an impassable divide between women. Over and again we see Scott redefining the value of women by calling attention to the flaws in the system which assigns them their value.

Lady Melvyn is, to all appearances, a bad woman. She views her stepdaughter as a rival, and schemes to get rid of her in any way possible, first by carting her off to boarding school, and then by marrying her off against her will. When a very Solmes-like suitor, Mr. Morgan, petitions for Miss Melvyn's hand, Lady Melyvn does all in her power to arrange the marriage. She even goes so far as to bribe a neighboring farmer into claiming that he has had an illicit affair with Miss Melvyn. The gullible Lord Melvyn is no match for either his wife's coquetry or cunning. Despite Miss Melvyn's protests, she finally consents out of duty to her parents' wishes. The marriage is, of course, miserable, and worse yet Mr. Morgan demands that his new wife break all ties to her friend, Louisa. Lady Melvyn, jealous of the two women's intimacy, seemingly delights in their forced separation. She would seem to be a very evil woman.

However, I argue that Scott makes it possible for readers to sympathize with Lady Melvyn. When interrupted by the dinner bell, Mrs. Maynard and the other women begin to discuss with Lamont and Sir George the nature of society and the women's willingness to live without "society." Mrs. Mancel responds that they have not rejected society, but a world in which "a constant desire to supplant, and a continual fear of being supplanted, 
keep the minds of those who have any views at all in a state of unremitted tumult and envy..." (111). While the fear of being supplanted could apply to both men and women, arguably it is felt more powerfully by women who are all too aware of the limits of their perceived value. In fact, Miss Mancel has experienced, time and again, the disadvantage of her beauty which inspires the envy of other women. Although she tries to seek work as a waiting maid to other women, too many of them are afraid that she will steal their husbands. Similarly, Lady Melvyn's fear is that the more beautiful, more youthful Miss Melvyn will supplant her. Yet Miss Mancel's sympathetic explanation of jealousy serves to rescue Lady Melvyn from condemnation. Having immediately followed a description of the envious Lady Melvyn's manipulations, Miss Mancel's philosophy works as a defense of Lady Melvyn's actions. She is not so much to blame as a society that positions women against each other, keeping them in "unremitted tumult."

Lady Melvyn's implicit defense continues. As the company walks outside the hall, the conversation turns on the inhabitants of a neighboring mansion, a refuge for aristocratic women reduced to indigence. Mrs. Maynard suggests, "the world is less inclined to pity them; but my friends see human weakness in another light." They are not, she continues, rendered "unworthy of compassion"(115). Mrs. Maynard is speaking of the fallen pride of wealthy women, whose demise is often owing to their own mistakes, but her philosophy transcends this context suggestively to include all "fallen" women. Human weakness deserves compassion, she argues. A place like this might have housed the Sallys and Pollys of Richardson's world. The reader is silently urged to reconsider Lady Melvyn, described as "void of delicacy,...formed on too large a scale, and destitute of grace" (89). Thus, "it is not strange, that she did not choose to give opportunities of 
comparison between herself and a daughter, who, though not so striking at first sight, was filled with attractions" (89). To maintain her own value, she has had to push her stepdaughter out of doors. And yet as Mrs. Maynard explains, "If we are despised for casual deficiencies, we naturally seek in ourselves for some merit, to restore us to that dignity in our own eyes, which those humiliating mortifications would otherwise debase" (115). In other words, when society renders them valueless, women are forced to compensate. For Lady Melvyn, this has meant finding ways to seem valuable next to the truly desirable Miss Melvyn. She has had to debase Miss Melvyn in order to feel better about herself. But she does so only because she lacks the physical beauty and feminine grace prized by society. Mrs. Maynard, like Miss Melvyn, implicitly accounts for Lady Melvyn's pride and envy and, while not entirely clearing her of guilt, puts the greater blame on cultural values.

In fact, Scott suggests that were society's rules different, Lady Melvyn's plots could not succeed in the first place. Miss Melvyn only concedes to the marriage because, artless, virtuous young women are ill qualified to contend with lady Melvyn, especially in an affair which could not be rendered public without hazarding Miss Melvyn's character; for reputation is so delicate a thing, that the least surmise casts a blemish on it; the woman who is suspected is disgraced; and though Lady Melvyn did not stand high in the public opinion, yet it was scarcely possible for any one to believe she could be guilty of such flagrant wickedness. 
Although forced by her stepmother, Miss Melvyn is really undone by social rules and assumptions concerning proper female behavior. At least four of these rules or assumptions are put to the test here. The first is the notion that daughters cannot disobey their parents, a rule which Haggerty says Lady Melvyn uses to her advantage: she “claims the prerogatives of the sex-gender system and fits her 'daughter' into a rigid social hierarchy that places her (the stepmother) on top" (116) ${ }^{77}$ To be a "good" girl, Miss Melvyn cannot directly confront or "contend" with her stepmother, nor can she defy her father, however much Lady Melvyn has manipulated him. In fact, over and again she has quietly accepted her abuses because to do otherwise would be considered improper. Scott clearly criticizes conduct book morality which instructs young women to obey their parents at all costs.

Miss Melvyn's ability to defend herself against such abuses is not only restricted by her role as a daughter, but as a woman. A "good" woman does not rival other women, even in self-defense. When Lamont expresses surprise that Miss Melvyn's pride could withstand Lady Melvyn's assault, Mrs. Maynard simply explains that “[w]ickedness serves itself by weapons which we would not use" (129). The "bad" girl's aggressive strategies are not an option for a "good" woman. However, lest one argue that Scott is replicating a good/bad girl binary, we should pay attention to the analogy she uses: that a courageous man should not be ashamed if someone kills him in his sleep. The suggestion is that the "good" woman's reverence for propriety renders her unconscious, unaware, oblivious - and grants to "bad" women willing to forego propriety a de facto advantage. Even if she could fight against her stepmother's claims, Miss Melvyn is bound by a social system that tends to blame the (female) victim. Just as Clarissa was unable to defend 
herself against accusations, so too is Miss Melvyn trapped by the sexist and misogynistic assumptions of her world.

Finally, Miss Melvyn is imprisoned by the contradictory notion that a woman of Lady Melvyn's standing could never act so "badly." The irony, of course, is that they would readily believe Miss Melvyn could act with such impropriety. In fact, as Haggerty points out, Lady Melvyn's feigned hysteria (weeping, fainting) over the idea that Miss Melvyn has put her virtue at risk fits right into patriarchal ideas about women (116). Lady Melvyn's hysteria appears to confirm the truth of what she is saying. Scott is clearly calling into question a patriarchal order that hystericizes women's bodies. Miss Melvyn's dilemma is largely the fault of gender expectations of which Lady Melvyn, herself a victim, can take advantage. In this, Scott clearly differs from Richardson who reserves no pity for the fallen women of Clarissa and, as I have argued, holds women most culpable for the evils of society.

When Miss Melvyn, now Mrs. Morgan, arrives at her husband's home she is dismayed to find it in disrepair. Worse yet she encounters another rival, an envious sister-in-law, the aging Susanna. Like Lady Melvyn, Susanna lacks “any natural attractions" and thus "[e]very pretty woman was the object of her envy"(133). Yet Susanna's story works, like Lady Melvyn's, to excuse her actions as the inevitable result of a misogynist society. While her aunt had willed to her immense wealth, the homely Susanna had no access to it until her aunt died. Thus, suitors came and went, all discouraged by the aunt's refusal to depart the world and the often love-struck Susannah thus "lived in a course of disappointments" (133). While the description of her is familiar (she is ugly, mannish, pedantic), she is also noted as "tormented inwardly" and 
immensely unhappy (133). Susanna does not figure largely in the narrative; she enjoys a two-page description, mostly of her monstrous physical features, and then drops out of the story. We hear much later that she has married unwisely and is miserable - apt "punishment" for her misbehavior...or not?

One might ask why Susannah is included at all. As a rival, her only offenses are to criticize Mrs. Morgan's domestic economy and to encourage Morgan's abuses of his wife. Clearly, she is yet another example of the ways in which the world pits women against each other. Read sympathetically, as I believe Scott intends, Susannah is the victim of a society that assigns her limited value; without beauty her value lies only in her fortune. Because Susannah's story is framed within arguments for compassion, one does not get the same sense of pleasure that one might get reading of the fate of Richardson's Arabella, also rewarded with an unhappy union. One is instead tempted to sympathize with her "disappointments."

Meanwhile, Louisa, who has moved to be close to Mrs. Morgan, is experiencing a tyranny of another kind: her beauty. Treated like a spectacle in church (not unlike the dwarves and giants of Millenium Hall), she is finding that "in her situation beauty was a disadvantage" (135). She seeks refuge at the home of Lady Lambton, a good but proud woman. Unfortunately, Louisa attracts the attention of Sir Edward, Lady Lambton's nephew. However, the proud Lady Lambton will not hear of a union between Edward and a woman of obscure birth and no money, no matter how "good" she might be. Rather than becoming angry with Lady Lambton, however, Louisa understands and accepts her will. Nor is Louisa persuaded when Edward asks her to respect his own wishes more than "the woman who could ungenerously and injudiciously set a higher 
value on riches and birth than on her very superior excellencies" (141). Louisa chooses her allegiance to her female friend although even the narrator terms Lady Lambton's behavior "inexcusable insensibility" (143). However, Scott never flatly condemns the older woman, who remains resolutely likable, described as "a person of admirable understanding, polite, generous and good-natured; who had no fault, but a considerable share of pride...." (136). In fact, "her good sense, and many virtues, so qualified this one blemish, that it did not prevent her from being a very amiable woman" (136). Pride is a fault, but excusable, and as Scott makes clear throughout her novel, it is a learned vicenot a woman's inherent fault.

In fact, so likeable is Lady Lambton that Louisa cannot bear to make her uneasy, so she leaves the house to avoid seeing Edward; she, of course, seeks out placement in a house with another woman. While her next mistress, Mrs. Thornby, is concerned that because of her beauty, Louisa may be too proud to be a servant, Louisa's friend, Mr. d'Avora convinces her otherwise. He argues that Louisa's beauty has prevented her from becoming the servant of a married woman; "therefore it was only with a single lady she could hope to be placed" (146). Mrs. Thornby recognizes his logic as "reasonable," evidencing it as common knowledge. Only single women truly can be friends. Mrs. Thornby possesses no husband (or son), and thus no concerns that Louisa might supplant her. While the presence of a man interferes with the friendship between Lady Lambton and Louisa, that between Louisa and Mrs. Thornby is enabled by the absence of men. The two become close, and before long discover that they are actually mother and daughter. Here, Scott appropriates the trope of the orphaned heroine, restoring to her the 
matriarchal heritage often denied the heroine in masculinist fiction, ${ }^{78}$ and implicitly attesting to the strength of female intimacy.

Lady Lambton, Lady Melvyn, even Susannah, are ultimately redeemed by the subtexts of the novel. Their stories, if explored, might mirror those of other women, stripped of their pride, and now residing at Millenium Hall. Of course, one might then ask why they, too, do not end up at Millenium Hall. The answer does not lie in any natural moral superiority bestowed on women like Louisa and Miss Melvyn. Instead, one might argue that the women who end up at Millenium Hall do so out of luck-or what the women attribute to Providence. Louisa might have been raped and abandoned by Mr. Hintman had he not, fortunately, died moments before he intended to enact his evil plan. Of note, Louisa and Miss Melvyn are only able to finance Millenium Hall because Louisa, by another stroke of providence, encounters her real mother, Mrs. Thornby who, on her death, leaves to her daughter a vast fortune. Perhaps most convincing, however, is that Edward's death is viewed by the women as another fortunate turn, for had Louisa married him, "[h]er age, her fortune, and her compliant temper, might have seduced her into dissipation, and have made her lose all the heartfelt joys she now daily experiences..." (161). The suggestion is that even the pure Louisa is vulnerable to both sexual desire and men's manipulations. No natural superiority or inferiority exists in Sarah Scott's world. Rather, as the dying Edward laments, the fate of women seems to depend on "the disposition of providence" (152). That the women invoke "providence" evidences Scott's commitment to the Christian philosophy that God has a plan for all, however obscure and seemingly arbitrary that plan might be; yet Scott never investigates the ironies of this philosophy. Why, we might ask, is "providence" kind to some and not 
others? Why are some women delivered out of the hand of evil, and others left to the mercies of the world? She clearly shows that "providence" is not necessarily a reward for good behavior-while the women who are "saved" all turn out "good," they do not necessarily start that way or, at least, they possess the potential to become "bad."

The story of Lady Mary is a perfect example of the arbitrary nature of "providence." Orphaned at a young age, she is taken in by her aunt, Lady Sheerness. Lady Sheerness, a wealthy woman, shares many of the flaws of the other matrons of the novel: she is coquettish, dependent on public approbation, and loves to gamble. Yet the narrator explains her behavior as the consequence of an unfortunate marriage at a very young age to a much older gentleman who indulged her every whim. Thus, her follies were originally the consequences of her situation, not constitutional, though habit engrafted them so strongly, that at length they appeared natural to her. Surrounded with every snare that can entrap a youthful mind, she became a victim to dissipation, and the love of fashionable pleasures; destitute of any stable principles, she was carried full sail down the stream of folly. (173)

Significantly, we see that Lady Sheerness, too, is a "victim." Like Lady Lambton and Lady Melvyn, she has been misled by society's expectations, tempted into dissipation. Her follies are not "constitutional," not engraved in her femininity. Married too young to a man who indulges her like a child rather than treating her as an equal, she cannot help herself. Her "bad" behavior is habitual, not natural. 
"Providence" thus leaves Lady Mary in the hands of this morally suspect woman, from whom she learns to behave. No wonder, then, that Lady Mary's own coquettish behavior attracts the attentions of the rake, Mr. Lenman, who although already married, attempts to seduce her into eloping with him. While the gullible and foolish Lady Mary initially agrees, chance again intervenes. A female rival discovers Lenman's true intentions and relates them to Lady Mary to spite her. Interestingly, unlike Clarissa's female rivals who try to pull her down to their level, this rival gleefully disappoints Lady Mary's hopes. In effect, female competition here saves Lady Mary.

After being disappointed by Lenman, the coquettish Mary soon falls for another rakish suitor, Lord Robert St. George. In fact, she falls for him in part because he is "much caressed by the ladies, and supposed to have been very successful in his addresses to many" (180). The narrator laments, "This is always a great recommendation to the gay and giddy; and a circumstance which should make a man shunned by every woman of virtue, secures him a favourable reception from the most fashionable part of our sex" (180). In other words, Mrs. Maynard recognizes the ways in which society pits women against each other, and describes how female rivalry leads women to pursue men whom they should fear. Indeed, Lady Mary "saw his attachment to her in the light of a triumph over several of her acquaintances..." (180). A socially constructed rivalry thus precludes real love between men and women. Lady Mary takes as evidence the jealousy she feels "at the civilities he paid any other women" as one of the "symptoms of a violent passion" (181). Envy clouds her judgment. Her desire to flaunt her "conquest" among her female companions results in her having "talked a moderate liking into a passion" (181). Of course, Lady Mary's rivals eagerly gossip about her, increasing Lord Robert's ego and 
confidence in his ability to seduce Lady Mary. Nor does the vapid Lady Sheerness help to protect the young woman from Lord Robert's advances.

However, even as Mrs. Maynard describes Lady Mary's vanity, she works to save her from condemnation. She routinely reminds her listeners of Lady Mary’s young age and lack of guidance, and depicts Lord Robert as a predator willing to take advantage of Lady Mary's naivete. Lady Mary herself, however, is “innocent of vice” (182) and alarmed when Lord Robert makes his intentions obvious. Nevertheless, she believes that she loves him, and is "apprehensive, that is she quite deprived him of his hopes, she should entirely lose him, and he would attach himself to some other woman" (184). The spectre of the female rival haunts her, nearly persuading her to give up her virtue. Lord Robert, of course, preys on such fears, flirting with other women to encourage Lady Mary's jealousy.

However, Lady Mary is once again saved by a would-be rival. Miss Selvyn, another young woman, urges Lady Mary to reconsider her own behavior, suggesting that "no man that was not an absolute fool, or at the time intoxicated, ever insulted a woman with improper behavior or discourse; if he had not from some impropriety in her conduct seen reason to imagine it would not be ill received" (183). Lady Mary inspects her own behavior and finds that she is indeed partially to blame, but remains bewildered as to how to respond to Lord Robert. She looks to the woman who has offered her advice. Lord Robert, it turns out, had also courted Miss Selvyn, his affection for her decidedly more genuine because he recognized her more proper behavior and, therefore, treated her with more respect. 
Scott might have used these two women in a conventional good girl/bad girl binary to teach by example how a "good" girl wins a man. Lady Mary's coquettish behavior might then have looked very much like the modern-day example of blaming the victim. Yet Scott's narrative does not take this turn. Instead, despite Lord Robert's altered behavior, Miss Selvyn rejects him on the basis of his mistreatment of Lady Mary. While Miss Selvyn had warned Lady Mary against encouraging Lord Robert's impropriety, when Miss Selvyn rejects Lord Robert she much more clearly blames him. In a carefully orchestrated contest of wits between Miss Selvyn and Lord Robert, the former explains her refusal of his proposals:

[Y]our lordship's hopes must have been founded on Lady Mary's folly, not her real want of innocence; a folly which arose from the giddiness of youth, and the hurry of dissipation; for by nature Lady Mary's understanding is uncommonly good. By what you say, you imagined her honour was lawful prize, because she appeared careless of it; would this way of arguing be allowed in any other case? If you observed a man who neglected to lock up his money, and seemed totally indifferent what became of it, should you think yourself thereby justified in robbing him? But how much more criminal would you be, were you to deprive him of his wealth, because he was either so thoughtless or so weak, as to not know its value? And yet surely the injury in this case would be much less than what 
you think so justifiable. If the world has but the least sense of real honour in this light they must see it; and to that tribunal I imagine you think yourself answerable; for did you reflect but one moment on another bar, before which you will be summoned, you would see, there can be no excuse for violating the laws by which you are there to be tried. If you could justify yourself for the world, or to the women of whose folly you take advantage, by the fallacious arguments which you have so ready for that purpose, such cobweb sophistry cannot weaken the force of an express command. (209)

Carefully, thoughtfully Miss Selvyn dismantles Lord Robert's logic. She does not allow him (or her reader) to blame the victim. Instead, she puts his reasoning to the test, explicitly invoking metaphors of both legal and heavenly courts. Her analogy, comparing Lady Mary to a man careless of his money, is indeed problematic, leaving the notion of female virtue securely tied up in a masculinist value system. Nevertheless, she turns this economy on its head, using its own logic against it. Any reasonable court, she argues, would recognize that the real criminal is Lord Robert. Had Lady Mary been "robbed" of her virtue, the fault lies not with the woman careless of the value of her virginity, but with the man who would scheme to steal it from her. Moreover, Miss Selvyn argues that even if Lord Robert's "cobweb sophistry" convinces those in an earthly court, as she well knows it has before, that he faces a greater judge in heaven who will no doubt see past his lies. Lady Mary's condemnation of Lord Robert's behavior is a clear and cutting 
indictment of social rules that routinely remove culpability from men and displace it onto women. Surely we have seen Richardson commit the same atrocity when he allows Lovelace's own "cobweb sophistry" to condemn the "bad" girls of Clarissa.

Throughout the novel, exchanges such as the one between Miss Melvyn and Sir Robert work to rescue "bad" girls from contempt. When Sir Robert asks whether Miss Melvyn would "require [men] to respect those who are not in the least respectable?" her answer is another important revision of Richardson's narrative. She replies, “No,...I only wish you would cease your endeavours to render those women objects of contempt, who deserve only to be neglected, and particularly not to deprive them of the very small portion of regard they are entitled to..." (210). The reader is simultaneously asked to reserve some pity for women who are otherwise rejected by society because of their misbehavior.

The readers' compassion for "bad" women is again called on in the section of the novel entitled, "The History of Mrs. Trentham." Here the reader is given the story of Harriot Trentham, orphaned at eight and left to her wealthy grandmother's care. She is immediately viewed as a rival by her female cousins, who also live with the grandmother. Yet while Harriot's good behavior is clearly contrasted to that of her cousins, we are told that their faults are not innate, but the effects of social conditioning. Mrs. Maynard explains:

The first thing a girl is taught is to hide her sentiments, to contradict the thoughts of her heart, and tell all the civil lies which custom has sanctified, with as much affectation and conceit as her mother; and when she has acquired all the 
folly and impertinence of a riper age, and apes the woman more ungracefully than a monkey does a fine gentleman, the parents congratulate themselves with the extremest complacency, on the charming education they have given their daughter.

Harriot had been taught no such lessons. (224)

Harriot is no match for Miss Alworth or the Denham sisters, who envy her beauty and good heart, both of which attract the admiration of all those who visit the house. In fact, "[t]heir hatred to her produced an union among themselves; for the first time they found something in which they all agreed" (225). While the girls' friendship is based on a mutual jealousy, clearly no stable foundation for a genuine relationship, Mrs. Maynard's interpretation of the story suggests that the fault is not really theirs. Set against each other by social custom, the girls use their envy to create a community. It is an act of desperation, and exactly the sort of female friendship which the healthy sisterhood at Millenium Hall is meant both to contrast and condemn.

While the girls plot against Harriot, she conversely works to aid their happiness. The reader is told of one man with whom Miss Alworth has fallen in love; the gentleman, however, loves Harriot and courts her first. Harriot, rather than undermining her plotting cousin, talks him into addressing her. This is not necessarily because she finds him unattractive, but because "she perceived that Miss Alworth was in love with him, and though she had little reason to have much regard for her, yet good nature made her anxious for the success of her passion which she saw was deeply rooted" (228). In fact, Harriot is so careful of her cousin's feelings that she advises Mr. Parnel how to turn his 
attention to the cousin so that it seems as if he has lost interest in Harriot. The result is that Miss Alworth, when addressed by Mr. Parnel, forms an intimacy with Harriot, asking her how she should behave in return. Where an author like Richardson might use the addresses of a handsome suitor to drive home the "badness" of the wicked sister/cousin, Scott instead encourages the reader to take pity on her and suggests that a compassionate view of female rivalry might actually lead to resolving difference.

In another instance, Harriot's rivalrous cousin, the younger Miss Denham, falls in love with a man whose expectation is a much larger dowry than she can provide. Harriot intercedes, offering the sum out of her own fortune, explaining that "the treatment she had received from her cousins, she attributed to childishness and folly, and should be far worse than they were, if she could remember it with resentment" (234). Later, she rescues another female cousin, Mrs. Tonston, from an unhappy marriage by counseling both her and her husband. The result is that "they now live in great amity together, gratefully acknowledging their obligation to her" (241). Over and again, Scott turns away from the trope of female rivalry which would otherwise leave the "bad" girl wallowing in her own misery.

There is yet another instance in which Scott rejects female competition. Harriot's male cousin, Mr. Alworth, loves and respects her, and they form a tight bond, agreeing to marry although both admit to feeling no passion for the other. While they are waiting for the papers to be drawn, however, Mr. Alworth's eye is taken by a young coquette, Miss Melman. Although Harriot is far superior, Mr. Alworth is mesmerized. Harriot, rather than feeling jealousy, agrees to dissolve their engagement and Mr. Alworth marries Miss Melman instead. He quickly recognizes the folly of his decision, and as time passes both 
Harriot and Mr. Alworth realize that they do love each other. While Mr. Alworth has difficulty suppressing his passion, Harriot refuses to become a rival to the former Miss Melman. Instead, she moves to London and continues to correspond with him, always recommending that he turn his attention to his wife and salvage their marriage. While Harriot has had to suppress her own passion, she is rewarded by being granted the responsibility of educating Mr. Alworth's ten year old daughter at Millenium Hall. There is never any sense of Miss Melman's reformation; however, Harriot's refusal to compete with her results in both the moral improvement of Mr. Alworth and his child. Moreover, we cannot help but put Miss Melman into the same category as the "childish" cousinsall victims of social conditioning.

In contrast to Scott's compassionate view of "bad" women, one cannot help but think of Belford's and Lovelace's (and implicitly Richardson's) condemnation of the women at the Sinclair household. As I have argued, the description of Mrs. Sinclair's deathbed scene is particularly scathing, as the "bad" woman is effectively metaphorically and literally dismembered. Yet one gets the sense that a Mrs. Sinclair in Millenium Hall would be deemed worthy of pity. Much earlier in the novel, Mrs. Maynard gives to Sir George and Lamont a tour of a building on their property in which live a company of dwarves, giants, and those afflicted by various deformities. Mrs. Maynard explains, Here they find refuge from the tyranny of those wretches, who seem think that being two or three feet taller gives them a right to make them a property, and expose their unhappy forms to the contemptuous curiosity of the unthinking multitude. Procrustes has been branded through 
all ages with the name of a tyrant; and principally, as is appears, from fitting the body of every stranger to a bed which he kept as the necessary standard, cutting off the legs of those whose height exceeded the length of it, and stretching on the rack such as fell short of that measure, till they attained the requisite proportion. But is not almost every man a Procrustes? (72)

This important passage no doubt works to secure links that are made throughout the text between the "spectacle" of these creatures and those of women's bodies. ${ }^{79}$ Like the "spectacle" of Louisa's and Harriot's beauty, these deformed and monstrous bodies draw the attention of those who seek to commodify them. However, we also have been witness to the "spectacle" of the "bad" girls' physical unattractiveness and monstrous misbehavior. ${ }^{80}$ Mrs. Maynard's cunning reference to Procruste serves several functions. First, it forces Sir George and Lamont to recognize their own complicity in a tyrannical social system. It also draws attention to a market economy that reduces all value to a common standard. Because the novel emphasizes society's tendency to treat women like property, Mrs. Maynard's offers a clear critique of an economy that depends on judging all women by a common standard-i.e, to an exemplar. In Mrs. Maynard's revised economy, there are no such common standards. Here, the exemplar Clarissa could not exist as such. Instead, she would be only one version of femininity. Women, she suggests, come in all sizes and shapes, and should not be fit to a bed and their legs cut off to make them conform to any standard. One cannot help but think of Mrs. Sinclair, in our last view of her strapped to a bed, her leg cut off, howling like a beast. For Richardson, 
there was only one standard-and no room in his fictional world for any deviation. It is a world Sarah Scott must at least try to revise.

I thus find wrongheaded those who have argued that because Millenium Hall functions as an escape from the outside world, it has undermined its feminist potential. Lisa Moore, for example, has suggested that, "the notion of liberty as 'freedom from' persecution, rather than 'freedom to' act on one's behalf, animates the depiction of the power of the Millenium Hall women" (44). She claims that the women may have found refuge from male persecution, but have not found liberty. Concludes Moore,

The 'safety' of Millenium Hall is made possible by the refusal to critique the social hierarchies that make such a refuge necessary. This gesture of refusal guarantees that there will always be a function for this female 'utopia,' for the conditions outside its walls, left intact and operative, will continue to populate it with 'monsters,' women, and other victims. (48)

I suggest, however, that Scott's project, both utopia and novel, is an aggressive act of revision to both traditional narratives and the epistemology of eighteenth-century womanhood. As I have demonstrated, much of the novel rests on a very explicit critique of the social hierarchies that create the conditions of women's oppression and resulting “bad" behavior. Moreover, I believe that the women's decision to create Millenium Hall is conscious. They choose how to appropriate their money. They choose not to marryLouisa, in particular, rejects her many suitors after Edward's death, as does Harriot after 
Mr. Alworth marries. Others outside its halls choose to send their daughters there to be educated. According to the rules, they can all choose to stay or leave. ${ }^{81}$ Millenium Hall, then, is less an escape than a conscious refusal of the social conditions that pit women against each other.

\section{Conclusion: A Modest Proposal for Healthy Competition?}

While Scott avoids female rivalry based on competition for a man or male desire, she also resists the trap of sisterly utopia which would eschew any form of female competition. Helena Michie, examining Victorian texts which celebrate female sorority suggests that tropes of sisterhood actually work to assimilate otherness, to reduce all to the "same." In these texts, a "good" sister is invariably contrasted to her "bad" sister. The two compete, the "good" sister winning, and finally forgiving her "bad" sister for her misbehavior. In the end, the "bad" sister becomes "good." In effect, rather than challenging patriarchy, "sisterhood" upholds it. Explains Michie, "The capacious trope of sisterhood allows for the possibility of sexual fall and for the reinstatement of the fallen woman with th0e family...Sisterhood acts as a protecting framework within which women can fall and recover their way, a literary convention in which female sexuality can be explored and reabsorbed within the teleology of family" (18). The problem, of course, is that these "fallen" women can only be redeemed by returning to the utopia, to enclosure, to "sisterly" acceptance. Michie explains this contradiction: "Permanence is both the promise and the nightmare of sisterhood; to be absorbed into the family is to know no escape from its idiom, its pleasures, and its punishments... The pure sister protects the fallen one precisely by participating in a system that allows for the opposition between pure and fallen" (18). Michie's argument, however, is not that all Victorian 
representations of sisterhood, because of their dependence on good girl/bad girl binaries, should be read as "unsisterly." Rather, she argues, "fictional representations of sisterhood provide a place and a vocabulary for the representation of a range of stereotypically unfeminine feelings and behaviors" (21). Among these "unfeminine feelings and behaviors" are aggression, hostility, and competition—traits normatively associated with men or with demonized women (as in the Sinclair household of Clarissa). Yet Michie argues that contemporary feminists need to recognize ways in which the expressions of such feelings and behaviors, because of their resistance to stereotypes, work to empower women. To refuse to recognize that women can be competitive is to buy into an idealizing and oppressive image of Womanhood.

In fact, it is the very inclusion of "bad" girls which enables Scott's social critique. The point is not to reform their behavior, but that social conditions make it nearly impossible for them to act otherwise. James Cruise suggests:

By exposing the vanity, invidiousness, and competition that characterize female relationships, the histories underscore two valuable and related lessons. The first is the scarcity of examples of female excellence that women of sense could emulate as they attempt to anchor their identities in the world at large... The second lesson builds on the first: unchallenged assumptions about the role of women in society validate only those female types that are consistent with the normative codes and prescriptions of character that have cultural currency. Under the circumstances, 
customary forces can easily overpower and exclude a right as rare as female autonomy, particularly when there is not much of an intellectual structure in place to support it.

Repeatedly, the women censor society for this very mistreatment, and they choose homosocial intimacies over heterosexual ones. Scott works to bring mothers and daughters, as well as "sisters" together. She also exposes a society that rewards "bad" rather than "good" women—as I have argued, a point that Miss Melvyn's inevitable surrender to her stepmother's conniving behavior makes clear. Because Scott rejects female rivalries, or at least calls attention to the conditions driving them, "this series of romances is transformed not into a predictable story of eighteenth-century women characters but into an uncommon and defiant history of collective fulfillment and enlightened self-interest" (Cruise 563). The women refuse individualized fulfillment because they recognize the necessity of reuniting with other women from whom they have been alienated, it seems, from birth.

Moreover, the narrative suggests that women do not have to become flat, uniform models of feminine virtue, but rather can continue to possess differences and engage in healthy competitions with each other. Millenium Hall encourages healthy competition among women in several ways. First, we know that the ladies of the house solicit the good behavior of their domestics "[b]y little presents [which] shew their approbation of those who behave well...This encouragement has great influence, and makes them vye with each other in endeavors to excel in sobriety, cleanliness, meekness and industry" (168). We are told that it is not the value of the gifts which they treasure, but rather the 
approbation which those gifts signify. At the school for girls Lamont and Sir George appreciate the beauty of its garden and are told that the girls, "by the notice taken of it, are taught to vye with each other which shall best acquit themselves, so that perhaps never was a garden so neat" (197). The girls compete with each other, but the basis of their competition is collaborative, and the end result is mutually beneficial. Rather than competing for financial gain, they vye for the genuine love of their mistresses. This type of competition is in direct contrast to that between the women outside Millenium Hall.

Some critics, however, have argued that the utopia depends on the voluntary labor of the working-class, and thus, a tacit acceptance of class hierarchy. As Johanna Smith, for example, suggests, "Although this gratitude economy may seem to run on "very different principles' from the masculine economy outside Millenium Hall, it is in fact a feminine version of that masculine economy, for its superstructure of philanthropy creates and rests on a base of exploited labor" (273). Smith suggests that the "debt" which they owe their class superiors for saving them is paid off by working for them. However, I would argue that the labor of the women at Millenium Hall is not exploited. Mrs. Maynard, in fact, has kept the carpet factory out of the hands of "an enterprising undertaker" and "kept the distribution of the money entirely in their own hands: thus they prevent the poor from being oppressed by their superiors" (243). The money made from the carpet factory, rather than enriching any one individual, works to "enrich all the country about" (243). And the distribution of wages is in direct contrast to that in a capitalist economy, more being given to the children and the elderly who can perform the least amount of work (243). 
While they do not create the kind of utopia imagined by Irigaray, the women at Millenium Hall do effectively change the rules of the game by transforming the value system. Like Eve Tavor Bannet, I wish to "distinguish between law and license, and between subordination to another's will and 'free' self-government by principles of virtue and law" (172). ${ }^{82}$ While the women may indeed be obligated to each other, they are agents, not objects of exchange. In fact, they are more successful agents than men. As Mary Peace has argued, while much writing of the period situated women at odds with commerce, Millenium Hall displays women pursuing commercial activity and achieving success. Peace suggests that Scott's novel reflects Hume's logic that women, "more refined in their sensations," may be better suited to conducting commerce (Peace 311). If Scott keeps intact a class hierarchy, it is one in which rank is ultimately subordinate to friendship and mutual love.

Why then, one might ask, is even the architectural layout of her utopia organized around class? Susan Lanser has noted that the upperclass women are separated from indigent gentlewomen who are also separated from working class women. Moreover, the working class women live in individual cottages because they otherwise quarrel with each other. Scott's purpose, however, is not to challenge class hierarchy, but to ask that it be treated responsibly. Moreover, I don't think Scott means to imply that women always get along; as I have shown, her long list of rules takes numerous precautions to avoid such competitions. The point then, is not that female rivalry exists or, as may actually be the case, that it is more visible between working women. ${ }^{83}$ What seems most significant is that Scott does create a mutually beneficial relationships between these women by avoiding the traps of unhealthy female competition. 
Critics have also argued that the ladies have "enslaved" those beneath them, operating a sort-of panopticon like surveillance and thereby maintaining the status-quo. Johanna Smith, for example, calls this "moralized management." Yet Scott seemingly anticipates such skepticism. Lamont, on hearing of Mrs. Maynard's plan, fears that she would "choose to make us all slaves to each other" (112). Mrs. Maynard's response, however, is that she desires "I would only make you friends" and that "this reciprocal communication of benefits should be universal" (112). In a world without the prospect of immediate financial gain, the damaging aspects of competition disappear. Says Mrs. Mancel, "The greatest pleasure this world can give us is that of being beloved..." (113). Yet this love must be deserved. The ladies earn love from those they rescue by providing them, without expectation of repayment, food, shelter, and respect. Those they rescue earn the ladies' love by demonstrating compassion and a desire to help others in turn.

The women do not work, in other words, as a means to financial gain. Scott explains the reasoning behind the ladies' emphasis on industry as an endeavor "to cultivate in this sisterhood that sort of disposition which is most productive of peace" (118). In other words, the concern is that so many women living together will soon start to quarrel. The answer is a Puritan- like industriousness. Explains Mrs. Maynard: "An idle mind, like fallow ground is the soil for every weed to grow in; in it vice strengthens, the seed of every vanity flourishes unmolested and luxuriant; discontent, malignity, ill humour, spread far and wide, and the mind becomes a chaos, which it is beyond human power to call into order and beauty" (118). The women are not enslaved. Instead, they are encouraged to cultivate their individual talents. The assumption is that women become rivals in the world outside because their industry is not encouraged. Upperclass 
women in particular are taught to value only their beauty, and to seek the desire of a man with money to support their idleness. However, the ladies of Millenium Hall teach their boarders to take pride in their individual accomplishments rather than beauty. Work is a healthy alternative to sloth, in the eighteenth century increasingly associated with women of the aristocracy. Work also works to unite all classes, to grant them common experience. They may perform different tasks, but they all work in order to help each other.

There are, of course, certain ironies which cannot be overlooked or argued away. Scott's utopia, like all utopian ideals, contradicts itself on several levels. Most obviously, to create a utopia, one must have the money to do so. ${ }^{84}$ Ironically, the women's "freedom" from exchange depends on the outside world; Millenium Hall is financed by the capitalist market. In fact, despite the women's abhorrence of slavery, it is notable that some of their money depends on the slave trade. ${ }^{85}$ In particular, Mr. Hintman's generosity is in keeping with a masculinist gift economy. He does expect a return; he plans to seduce, then desert, Louisa. Thus, while Louisa works to transform his version of the gift economy, her financial empowerment depends on the value of her physical beauty, which attracts Hintman in the first place.

Moreover, although the wealthy women of Millenium Hall can refuse to go to market, they can only do so by continuing to validate marriage and by submitting the working-class inhabitants to wedlock. It is only because the ladies at this "utopia" do not entirely reject marriage as an institution that their project is socially acceptable in the first place. They must, in a sense, sacrifice what can only be read as their "inferiors" to that institution. Lanser suggests, "Such representations...promote the benefits of female 
friendship at the expense of, and in tandem with, the consolidation of class hegemony" (187). Utopia, then, can be afforded only by those who can "afford" it. ${ }^{86}$

Ultimately, utopia works to underscore patriarchy. Lisa Moore has convincingly argued that Millenium Hall, although straining against the oppressions of patriarchal society, ultimately helps to strengthen its authority by posing a version of bourgeois, domestic femininity confined to the apoliticized space of home, and from within which the female panoptic gaze operates to control women's body and labor for patriarchal purposes. Although the women are empowered, the power attributed to them is always controlled and delimited by their male superiors. Moore also examines key points in the text within which the ladies of Millenium Hall resist the label of "reformer," insisting that they are not challenging society. Says Moore, “The women of Millenium Hall, then, enjoy their privilege only to the extent that they are willing to serve a hierarchized ideology in which they are inferior to the men who visit them from the 'foreign' realms beyond the domestic sphere" (31). Thus, even while the men's experience at Millenium Hall works to reform them, Sir George going so far as to establish his own version in Scott's next novel, Sir George Ellison (1766), the women's power to reform is always, already encased within assumptions about idealized (and asexualized) femininity. ${ }^{87}$ The very fact that Millenium Hall must exist as a utopia, removed from reality, cuts short the full potential of its feminist appeal. ${ }^{88}$

Nevertheless, Scott provides her readers with an imaginative space populated with several versions of femininity, both "good" and "bad," and effectively reworks the good girl/bad girl binary, even while maintaining it, to call attention to the conditions responsible for its very being. That she can only imagine good girls and bad girls coming 
together within a utopic space speaks less to the limitations of her vision than to the restrictions imposed by her culture. For Scott, her utopia however problematic was still a more authentic version of what she saw as the "real" nature of women's relationships with each other than that which any "realistic" fiction had to offer at the time. Ultimately, the "real" problem for Scott, in contrast to Richardson, is not girls behaving badly, but the bad behavior of a society in which those girls were forced to grow up and reside. 


\section{Chapter Three:}

\section{"Secure in his own castle": Female Rivalry and Feminist Revision in Frances Burney's Cecilia (1782)}

No one who has read Frances Burney's Evelina (1778) can forget the horrific depiction of two elderly women, "feeble and frightened," hobbling toward the finish line of a foot-race at the behest of two gambling men (346). As critics such as Kristina Straub and Audrey Bilger have noted, Burney clearly criticizes both the excesses of gaming and a misogynistic society. ${ }^{89}$ I suggest, further, that the race allegorizes the ways in which men routinely pit women against each other to their own advantage, and makes explicit a critique of women's rivalrous relationships that extends throughout all of Burney's works. ${ }^{90}$ How do we account for the reiterative emphasis on female rivalry, and what can Burney's depiction of women's antagonistic relationships with each other tell contemporary readers about the terms and conditions of female intimacy within a patriarchal society? Moreover, what might an examination of this depiction reveal about Burney's resistances to misogynist literary tropes?

Of the female friendships in Cecilia, editors Margaret Doody and Peter Sabor say, "We are a long way from Millenium Hall" (xxxv). Indeed, the novel presents no safe haven for female intimacy. Orphaned after her mother's death, Cecilia is taken in by her wealthy uncle, the Dean. Among her uncle's friends are Mr. Monckton and his wife, Lady Margaret, a despicable and jealous woman who despises Cecilia and teaches her hanger-on, Miss Bennet, to do the same. After her uncle's death, Cecilia moves to 
London to live with her guardian, Mr. Harrel, and his wife, Cecilia's childhood friend. Mrs. Harrel, however, proves to be a dissipated woman who experiences "no pleasure but to vie with some rival in elegance and to exceed some superior in expence" (33); she shamelessly helps her husband to squander away not only Cecilia's wealth, but the loan that, under duress, she advances to them. In London, Cecilia also meets the voluble Miss Larolles, a young woman who rejoices at the illness of another friend because she inherits her ticket to a masquerade, and the supercilious Miss Leeson, who refuses to talk to her because she is not part of her coterie. Another woman, Mrs. Belfield, the mother of one of Cecilia's would-be suitors, harasses her with wrong-headed and inappropriate assumptions about Cecilia's intentions towards her son, while her daughter, Henrietta, is an irritating, if never dangerous, rival for the affections of Cecilia's lackluster husbandto-be, Mortimer Delvile.

However, Cecilia's relationship with her future mother-in-law is perhaps the most vexed of female friendships. Left a great fortune by her uncle, Cecilia falls in love with Mrs. Delvile's son, Mortimer. Mrs. Delvile adores Cecilia, but complicating matters is a clause in the will demanding that Cecilia's husband take her surname, Beverly. ${ }^{91}$ Although her uncle meant to empower her, Cecilia is actually disempowered by the name-clause. Note Doody and Sabor, "For a woman the family name is less significant than it is to a man, as ancestral achievements have little to do with the obscured history of foremothers. A surname is the male portion of a woman's name, a reminder that women are supposed to blend in with a masculine social arrangement" (xvii). The name encumbers Cecilia, even as the fortune linked to it initially puts her in contact with Mortimer. 
Like Dean Beverly, the Delviles, proudly cherish their name, their last link to the aristocracy. Mrs. Delvile, having married her cousin, is more invested in her family's name than Cecilia; indeed, argue Doody and Sabor, "To endure that marriage, she has always had to make a fetish of the class and 'Family' she is upholding" but she is, ironically, "in parallel to Cecilia who has been legally chained to her surname 'Beverly' for life but feels no attachment to it" (xxvi). Yet despite their parallel situations and the sympathetic identification the women feel for each other, they are set at odds by a cruel system of patrilineage. Mrs. Delvile, like the other women of the novel, fails Cecilia for most of the novel; it is only after Cecilia's psychological devastation (following her clandestine marriage to Mortimer) that she becomes the ally for whom Cecilia has yearned.

Of course, Cecilia's alienated status is part and parcel of her role as exemplary female within the eighteenth-century didactic tradition. She must stand apart; she must be aware and help to make the reader aware of certain societal flaws. A departure from the epistolary mode employed in Evelina, Burney's second novel relies on what Doody considers a "sober, strong, and ironic third-person narrator" (101) to examine increasing class tensions. Because of significant changes in the economy, those families whose wealth was bound up in land and title were increasingly finding their status contested by those with new and often greater wealth borne out of trade and the capitalist market. ${ }^{92}$ The novel is clearly invested in figuring out how to adjust the value system to make room for competing notions of value. We see these ideological tensions caricatured in the rancorous exchanges between the "landed" Mr. Delvile and the "monied" Mr. Briggs. Mr. Delvile naively insists on the superiority of "family" while the penny-pinching Mr. 
Briggs revels in the pure materiality of money. Both are flat, uncomplicated characterizations, unable to fully depict the complex nature of the ideological crisis in value; hence, questions of value are more convincingly played out in the tug-of-war between Mrs. Delvile and Cecilia for the son's loyalties. ${ }^{93}$

That Burney chooses the trope of female rivalry to negotiate these tensions is significant. The parallels drawn between the two women, both victims of patrilineage, work to emphasize the contrasting ways in which they negotiate agency. Mrs. Delvile clings desperately to an antiquated feudal system. In contrast, Cecilia, although clearly a member of the landed gentry, champions a moral economy, making irrelevant the debate between the landed and monied by positing a system of class based on individual merit. She rejects fetishism of either name or money, insists on an internal value for women not measurable within the logic of the marriage market, and by example ultimately reforms both Mortimer and his mother. ${ }^{94}$

In Burney's domestic novels, as in many of her contemporaries', love is the galvanizing force that transforms the class system. In as much, Burney depends to some extent on a conventional good girl/bad girl(s) dyad to negotiate a shift in class epistemology. ${ }^{95}$ The "hero," Mortimer, falls in love with the "right" woman, who teaches him and his mother to recognize the problematics of a material economy and to privilege instead personal value and domesticity. However, I suggest that Burney also revises the conventions of the romantic love plot and, in doing so, undermines even as she reinforces domestic ideology. ${ }^{96}$ In her analysis of the ideological work performed by female rivalry, Diana Wallace has argued that women's fiction is part of a "triangular discourse with both the stereotypes of female rivalry in the dominant male discourse... and with female- 
authored texts...which privilege female bonds" (73). Critics have tended to position Burney as dependent on patriarchal affirmation. ${ }^{97}$ Yet recognizing the vexed position of women writers as triangulated complicates what has otherwise been read as her complicity with masculinist conventions. Burney does, indeed, seem pulled in two directions-accounting for what Kristina Straub has theorized as Burney's "unresolved doubleness" (6). Yet whereas Straub argues that "Burney is neither with us nor against us" (52), I recognize the potential for a feminist reading, a much more aggressive "with us" approach in which Burney exposes the limits of female friendship as the overdetermined condition of male privilege. In other words, her novel makes clear that patriarchy depends on reproducing myths of female rivalry, alienating women from otherwise empowering female ties.

This chapter begins with a re-evaluation of Burney's patriarchal complicity, examining her depictions of female rivals and what I see as her feminist revision of the conventional good girl/bad girl dyad. ${ }^{98}$ I then explore the motives underlying Mrs. Delvile's "bad" behavior, positing that Mrs. Delvile's jealous guarding of her son forces her into a rivalry with Cecilia which is really a displacement of the women's mutual desire for each other. In other words, the narrative is one within which women desire each other, but must channel their desires through a male; thus, I begin with a discussion of Mrs. Delvile's eroticized desire for her son in order to then explore the ways in which the son's object-status enables the displacement of female homoerotic desires. A consideration of Cecilia and Henrietta's relationship provides further support for my argument that the novel insistently privileges female intimacy over the female rivalries with which it is glutted and the conventional marriage with which it ends. Finally, I close 
with an analysis of Burney's own vexed relationships with her stepmother as a possible biographical impetus for her interest in the theme of female rivalry.

\section{The Trope of Female Rivalry}

I want to begin by considering the ways in which Burney reproduces the narrative of female rivalry in her fiction. As noted, she depends on the good girl/bad girl dyad to contrast Cecilia's exemplary status against negative exempla in the novel. In doing so, Burney herself forces the reader to choose sides against the "bad" girls. It is significant that Burney employs the third-person, omniscient narrator to employ this contrast. After all, as a "good" girl Cecilia cannot draw attention to her own superiority; as an exemplum, she must neither possess nor acknowledge a desire to compete with other women. Even the narrator, presumably a female voice, depends on strategies of indirect aggression, which, as feminist critics have noted, is typical of female competition. While the eponymous heroine of Evelina (1778), also encounters "rivals," the form of Burney's first novel is not as conducive to exploring the terms and conditions under which women compete; as Doody and Sabor suggest, using a narrator rather than an epistolary approach enables the presence of a self-reflexive irony which I argue we can see at work in her depictions of female rivalry in Cecilia.

In her wide-ranging, socio-cultural, psychoanalytic examination of female rivalry, Phyllis Chesler explains that one method of indirect female aggression is to call attention to another woman's stupidity. The narrator, in positioning Cecilia as the exemplary character, consistently notes the inferior intelligence of the women she encounters. For example, Miss Bennet is described as "lowborn, meanly educated, and narrow 
minded"(11), Mrs. Harrell as having "no pretensions to the wit or understanding of [Cecilia]"(21) and "her understanding naturally weak" (33), Miss Larolles as "talking faster than she thinks," and Lady Honoria as "uncultivated, and...totally void of judgment or discretion"(484). The amiable Henrietta is "simplicity uniformed" and “wants intelligence"(571) and even Mrs. Charleton "had not been the friend of her choice" as she "was not a woman of bright parts, or much cultivation"(712). Thus, Cecilia's moral superiority is, in part, based on her intellectual superiority. She represents the Enlightenment's emphasis on reforming women's education, if only to make them better wives and mothers. In a merit-based economy, as advocated by conservatives like Mary Astell and Hannah More, an educated wife is of greater value than a wealthy one. Of course, Cecilia's greater intellect does not mean she has a better chance at independence; she will simply make a better companion in marriage. The irony is that, because better educated, she is all the more acutely aware of how little choice she actually has. Thus, while one of these more "stupid" women might be delighted at finally marrying the lackluster Mortimer, the narrator notes that the experience is less than fulfilling for Cecilia. Instead Cecilia recognizes about her happiness with Mortimer: “--yet human it was, and as such imperfect!...Rationally, however, she surveyed the world at large, and finding that of the few who had any happiness, there were none without some misery, she checked the rising sigh of repining mortality, and, grateful with general felicity, bore partial evil with chearfullest resignation" (941). A woman like Henrietta or Miss Larolles cannot view the world "rationally" and the narrator implies are therefore, to some degree, better off. Cecilia, although smarter, is no more "free" from the confines of patriarchal logic than they. She knows full well what she has been forced 
to give up, thus she only can be resigned. In other words, Burney complicates the good girl/bad girl dyad by viewing cynically the rewards for "good" behavior.

Another strategy of female competition is questioning a woman's potential to be faithful, and the narrator of Cecilia certainly seems to enga ge in such speculation about the other women's behaviors. Surely Lady Honoria's failure to take marriage seriously, preferring a match with a simpleton whom she can control and admitting that her "eyes tire extremely of always seeing the same objects" (465), might lead to infidelity once she is married. Burney predates Mary Wollstonecraft, who will argue in Vindication of the Rights of Woman (1792) that women educated in a system that values beauty and wealth above all else "are only fit for a seraglio!" (83). On one hand Cecilia seems in direct contrast to these women, loving only Mortimer and pining away for him despite the numerous marriage proposals. Yet Cecilia is, to some degree, also unfaithful—for she wavers back and forth between her commitment to Mortimer and to his mother. She is, in fact, torn between the two-as I will discuss below-and makes promises to both that she cannot keep. At varying points, both Mortimer and his mother feel betrayed by Cecilia, neither able to get her to resign her agency. In fact, Cecilia's moral indecision is portrayed as of far more consequence than Lady Honoria's irreverent attitude toward marriage. A woman's infidelity, whether to a man or another woman, is thus disclosed as the inevitable outcome of women's restricted, often coerced choices.

Further, even as she positions Cecilia against these women, Burney is deeply invested in disclosing the painful effects of female rivalry. For example, the novel explicitly condemns one strategy of indirect female aggression-gossip. Chesler explains that gossip is often used for "other women's shame and 'social death"'(158) and 
that it is "the most powerful way in which utterly subordinated women enforce their own subordination and also improve their own positions in the all-female hierarchy of subordinated women"(161). As an ideological tool, gossip "reinforce[s] traditional morality, solidif[ies] group identity, exclude[s] outsiders, and serve[s] as a warning that one may become the focus of gossip if one behaves anti-normatively"(Chesler 154). The novel is rife with female gossips, to include the less dangerous Lady Honoria and Miss Larolles, as well as the ego-driven Mrs. Belfield, whose erroneous suspicions spawn the town gossip which eventually forces Cecilia into a clandestine marriage and then out of her own house. Further, while solidifying the identities of some women, like those of Miss Leeson's coterie who "make it a rule never to speak but to their own cronies" (40), the threat of being "gossiped about" insures that women can never really trust each other. For example, Mrs. Harrel, following her financial ruin, becomes the target of gossip by the very women she once called her friends. Burney implicitly condemns women's gossip and the exclusion of "unpopular" women.

Burney is also highly invested in explaining women's "catty" behavior as not natural, but the necessary result of their dispossessed status in society. She makes clear that women bully each other because they are all too cognizant of the contingent status of women's power. Women, trained to view other women as rival commodities, also fear each other as inevitable replacements. In Cecilia we see clearly that the women react to each other as rivals because they recognize that their value, based in youth and beauty, lacks stability. The aging Lady Margaret has known this all along. She wishes Cecilia married, even if unhappily, and bereft of her fortune, just to have her out of the picture. Even though Cecilia does not want Lady Margaret's husband, does not even recognize 
his salacious desire, and is, in fact, far kinder to the older woman than her husband has ever been, Lady Margaret focuses all of her hostility on Cecilia. Lady Margaret is trapped in a loveless marriage, yet whether duped by Monckton into believing he loved her despite her advanced age, or having consented to marriage because afraid to be alone (we see the possibilities for aged, single women in Evelina), she cannot turn her rage on the system. She turns it, instead, on Cecilia—a typical reaction, according to social psychologists. $^{99}$

Of course, none of the women are able to challenge male authority. To do so is to face what Mrs. Delvile laments as the "misery of domestic contention" (642) when she is torn between the conflicting desires of her husband and son. Thus, Lady Margaret allows Monckton to manipulate her, Mrs. Harrell enables her husband to squander away her own fortune and part of Cecilia's, and Mrs. Belfield states quite matter of factly of her son that “he's all for having his own way, poor dear soul, and I'm sure I don't know who could contradict him, for it's what I never had the heart to do" (314). It is much easier, then, for women to contradict each other. In other words, aggression against each other can be read as displaced resentment against the patriarchal system. Instead of acting out against their oppressors, the women of the novel act out displaced aggression against each other, ironically reinforcing the conditions of women's oppression.

Arguably, not all the women of novel are allowed the development to resist the good girl/bad girl dyad. Mrs. Belfield, for example, is not treated sympathetically, and remains a rather flat character, her greedy behavior an easy foil for Cecilia's charitable spirit. Nevertheless, her motives are made more apparent in the character of Mrs. Delvile, so that even though the novel does not complicate Mrs. Belfield's psychology, 
the reader can imagine that the reasons underlying Mrs. Delvile's "bad" behavior also apply to the novel's other "monstrous" mother. In fact, so careful and thorough is Burney's treatment of Mrs. Delvile's behavior that the reader is led to condemn not the women of the novel, but their social environment.

\section{Mrs. Delvile, Mortimer, and Maternal Incest}

It is in describing Cecilia's relationship with Mrs. Delvile that Burney enacts her most rebellious resistance to the tropes of female rivalry. Having lived with the Harrels until they have exhausted her patience and a large portion of her inheritance, Cecilia decides to move in with her guardian, Mr. Delvile, his wife Augusta, and their son, Mortimer. As a family they retire to the country where, removed from the scene of upstart ambition, the class-envious Mr. Delvile finally feels "secure in his own castle...He was not, as in the great capital of the kingdom, surrounded by competitors; no rivalry disturbed his peace, no equality mortified his greatness" (458). Although the crumbling castle walls would provide little defense against monied invaders, the Delviles continue to insist on their class superiority and to fetishize the name that binds them to the aristocracy. Initially they are unaware that the larger threat lies within the castle walls in the unassuming figure of Cecilia. It soon becomes apparent to all, however, that Cecilia and Mortimer have fallen in love, and that because of a name clause in the Dean's will, their romance must come to an untimely end. Ironically, it is Mrs. Delvile who officially puts a stop to their romance. As efficiently as the moat surrounding their castle, Mrs. Delvile patrols the borders of her family identity. However, the novel makes clear that as a result, Mrs. Delvile's life, like the castle, is "dark, heavy and monastic,... in want 
of repair and of improvement" (457). Mystified by her commitment to notions of aristocratic lineage, both her relationship with Cecilia and with her son are perverted and the drive of the narrative is to reveal the extent of her moral decay, as well as to reform her.

Significantly, the major conflict occurs between Cecilia and Mrs. Delvile, rather than Cecilia and Mr. Delvile, or even between Mortimer and his father. Burney's narrative choice raises an important question—just what does Mrs. Delvile gain by rejecting Cecilia as a daughter-in-law? At least one answer is domestic peace. To keep her husband "secure in his own castle," she must thwart Mortimer's marriage hopes. Yet it is not enough to suggest that Mrs. Delvile is merely pacifying Mr. Delvile. Clearly, she, too, is invested in the family name. After all, the name was hers even before she married Mr. Delvile. Rationalizing her troubling behavior, Mrs. Delvile explains that Mortimer is "the darling of my hopes, the last survivor of his house, in whose birth I rejoiced as the promise of its support, in whose accomplishments I gloried as the revival of its luster" (640). Mrs. Delvile's desire to preserve the house (castle) within which her family resides speaks to her internalization of patriarchal and, more specifically, aristocratic values; she, like her husband, rejects the arbitrary nature of status. Her identity is bound up in maintaining the truth of her family's natural superiority.

Yet it is also clear that Mrs. Delvile is more invested than her husband in maintaining the family's lineage. Her son is, she says, "the flattering completion of my maternal expectations" (677). Her maternal expectations are necessarily distinct from her husband's paternal expectations. As a woman, with little freedom, no rights to property, and no claim to fame other than her husband's name, she has invested in her son her 
vicarious desires for symbolic power. As a man, he can possess the agency she has been denied; because he was once part of her body, she feels intimately bound up in the course of his life. Burney's narrator makes clear that Mrs. Delvile bullies Cecilia not out of any masochistic pleasure, but because she rightly recognizes Cecilia as a threat not only to the preservation of the family name, but to her own self-preservation. Guarding his name, she resists her own effacement. The narrator says Mortimer "had a power over [his mother's] mind...that almost lulled her wishes to sleep; she rather idolized than loved him" (468). The distinction between idolatry and love is important because it represents the gulf between the material economy within which she resides and the moral one Cecilia represents. She is hypnotized, brainwashed, not aware of that which truly matters. But Mrs. Delvile's maternal investment only reproduces her own oppression. Like another monstrous mother, the homonymic Mrs. Belfield who forfeits her daughter because she overestimates her only son's value, Mrs. Delvile affirms the value of a phallocentric logic within which women are consis tently devalued-treated like debits.

Burney reveals both the motivating forces behind this complicity, as well as its costs. In effect, she discloses both the conditions and limits of women's precarious position of power within a patrilineal society, acknowledging the ever present threat of replacement. Cecilia is that threat materialized. Before Cecilia arrives, Mortimer "loved his mother not merely with filial affection, but with the purest esteem and highest reverence..." (462). Cecilia's presence threatens to steal from her that reverence which is the source of her identity. She fears the annihilation inevitable for women in a patriarchal economy within which they are treated as exchangeable commodities. Thus, it is not simply Cecilia she fears; I suggest that no woman would be "good enough" for Mortimer 
because all women threaten his mother's erasure. In other words, I suggest that although Mrs. Delvile claims to want to marry Mortimer off to a respectable aristocrat, conveniently no such opportunity arises. Not only does Burney fail to create a viable aristocratic rival for Cecilia, Mrs. Delvile never even suggests the presence of another woman lurking in the background. Thus, if on one hand Mrs. Delvile's protective guarding of her son resembles the moat surrounding the castle, she is also much like the devious Monckton who, dressed like a devil (a Delvile?) at a masquerade, circles Cecilia, warding off other suitors with his fiery wand. In the same way, Mrs. Delvile cuts him off from women who might rival her authority. Hers is an act of desperate resistance; by interrupting the romance narrative, Mrs. Delvile symbolically cuts her son off from the exogamous exchange of women supporting patriarchal privilege-an exchange to which she herself had been a victim. She subverts, if only temporarily, the traffic in women that underwrites her own inevitable replacement. ${ }^{100}$

On one hand, the absence of rivals for Mortimer's sexual desire keeps the focus on the tension between Cecilia and Mrs. Delvile, but on the other, it makes that tension appear very much like a sexual rivalry. Even Sabor and Doody note the family's "almost incestuous avarice that preys on itself, locking away its own treasures (in this case, persons)" (xxvii). Throughout the narrative, Mrs. Delvile's feelings for her son are uncomfortably eroticized. Her love for him surpasses filial devotion; says the narrator, "her fondness flowed not from relationship, but from his worth and his character, his talents and his disposition" (462). On one hand the description is meant to emphasize just how wonderful Mortimer truly is—even his own mother recognizes his desirability. In fact, her desire exceeds their mother-son bond, suggesting a relationship dangerously 
trespassing proper bounds. In one instance, Cecilia, who loves Mrs. Delvile passionately, worries that she will hate her for having "seduced from her the obedience of her son" (566). The term "seduced" suggests Mrs. Delvile's unacknowledged sexual desire for Mortimer. When Cecilia forfeits her claim to Mortimer, she exclaims to the older woman, “[L]et him, then, see me no more!--Take, take him all to yourself!” (675). Cecilia's tacit affirmation of the competitive nature of her relationship to Mrs. Delvile suggests both the pervasiveness and perversity of patriarchal logic.

The sexual dimensions of Mrs. Delvile's obsession with her son are obviated in the symbolic penetrations of his mind and body during the climactic chapter entitled, "Contest," within which the three meet to negotiate their desires. When she denies her son's requests to marry Cecilia, reminding him of his filial obligations, Mrs. Delvile is described as having "penetrated and tortured" him with her verbal barrage (677). In this same scene, her words are also a stunning "blow" which "strike," "pierce," and "sting" him to the soul. Lacking Monckton's phallic wand, Mrs. Delvile depends on the penetrating power of language to claim her son for herself. When at last Mrs. Delvile convinces Cecilia to forfeit Mortimer, Mortimer's response suggests the incestuous sexual violence implicit within Mrs. Delvile's behavior:

"At length, then, madam," cried Delvile, turning reproachfully to his mother, "are you satisfied? Is your purpose now answered? and is the dagger you have transfixed in my heart sunk deep enough to appease you?" "O could I draw it out," cried Mrs. Delvile, "and leave on it no stain of ignominy, with what joy should my own bosom 
receive it, to heal the wound I have most compulsatorily inflicted...." (674)

The phallic dagger plunged into his heart is, on one hand, the effect of Cecilia's betrayal in having chosen his mother over him. However, it also discloses the underlying perversity of the maternal relationship within patriarchal logic. Rather than protecting her son, she has injured him; rather than allying with him, she has betrayed him through her allegiance to an arbitrary system of status, and further, by her desire for power, if only over her son.

Having argued for the sexual dimensions of Mrs. Delvile's fetishistic desire for her son, I want to complicate this reading to suggest that this desire, although coded in sexual language, is partly emblematic of Mrs. Delvile's desire for tangible power. In other words, her act of penetration signifies a defensive resistance against her son's independence. Further, the very act itself suggests her attempt to subvert the gender system within which she is otherwise the object being penetrated. Explains psychologist Lee Fitzroy, "The one who penetrates, invades the body of the 'other,' is constructed as powerful in our social order. The victim is annihilated and therefore denied a separate identity" (qtd in Chesler 196). Mrs. Delvile, as a woman, has been denied a separate identity; she possesses value only in so far as she is married to Mr. Delvile and aligned with his name. Her investment in Mortimer, then, requires that he maintain the family line. She recognizes that to "concede [to the marriage], would annihilate every hope with which hitherto I have looked up to my son" (674). Plunging the knife into his heart, she symbolically annihilates the body that would diverge from her wishes. Returned to her symbolic womb, he cannot choose against her. Hers is an act of desperate resistance to 
patriarchal logic; although enmeshed, she struggles against its net, trying to find a way out, to escape at any cost. Yet she flounders in vain. Her aggression is simultaneously turned inward, an act of masochism she makes explicit in her wish to turn the knife on herself. She demonstrates the shame of patriarchal complicity, and the self-hatred of women consistently disappointed and devalued by society. ${ }^{101}$

\section{Mrs. Delvile, Cecilia and the Female-Identified Erotic Triangle}

Mrs. Delvile, even as she resists, nevertheless affirms and thus sustains the "truth" of a system within which women are interchangeable and daughters erase mothers. Yet I believe the "Contest" chapter yields another, more significant reading of Burney's feminist revision of the romantic love plot and its conventionalized female rivalries. What Burney makes clear is that the rivalry between the two women for the son's desire is really a rivalry between Mrs. Delvile and her son for Cecilia's heart. In fact, the relationship between Cecilia and Mrs. Delvile is far more erotically charged and overshadows the relationships of either of the women with Mortimer.

In order to arrive at this reading, however, we need to interrogate the object of desire over which the two women "fight." We can clearly see why Mrs. Delvile "desires" her son, not for himself but for the status he represents. But how do we account for Cecilia's desire? Mortimer, we discover, is never the true object of desire. In fact, the narrative emphasizes his undesirability. No Sir Charles Grandison, Mortimer's heroic acts consist of saving Cecilia from spilled lemonade (258), leaving a distressed Honoria in the midst of a lightning storm (479), catching a cold from his heroics (452), and warding off a pretend devil at a masquerade (111). A man who chooses to masquerade as 
a white domino of "no character" (106), he is consistently ridiculed by Lady Honoria for his "absence of mind" (349) and mental vacancy (486). His presence as a love objectfor any of the women- is not sufficient to account for the desire he inspires; thus, we must look elsewhere for the source of the women's rivalry. ${ }^{102}$

As I have already articulated, the patriarchal logic which these women have internalized invests his body with value. However, Girard's discussion of triangulated desire offers up a more provocative suggestion. Mrs. Delvile chooses Cecilia as a companion, the role frequently played by women of the lesser gentry, yet Cecilia's superior morality confuses the class hierarchy. Cecilia is the female exempla whose status is confirmed by the hero's choice of her. We are told Mrs. Delvile only chooses friends whom she thinks of as a "higher race of beings" (461) and she calls Cecilia both an "angel” (674) and "exalted creature" (675). Like Don Quixote's Amadis, Cecilia is a reflection of Mrs. Delvile's own ego ideal—she wants to be like her. It makes sense, then, to consider that her primordial desire for Mortimer, her fear that he will separate from her and thus annihilate her, is compounded by her desire to be like Cecilia. She, too, wants to be "chosen" by Mortimer, his choice of her affirming her likeness to Cecilia.

Mrs. Delvile's attraction to Cecilia is indeed reciprocated. Over and again throughout the novel she notes her admiration of Mrs. Delvile and her desire to be approved by her. I suggest, however, that a greater intensity defines the mediation within the triangulated desire of the feminist economy. Eve Kosofsky Sedgwick, elaborating on Girard to theorize male homosocial desire, notes: "Girard seems to see the bond between rivals in an erotic triangle as being even stronger, more heavily determinant of actions and choices, than anything in the bond between either of the lovers and the beloved" (21). 
Diana Wallace has extended Sedgwick's work to articulate a female-identified erotic triangle, arguing that women "can also operate within a 'female economy,' within which men can be commodified and exchanged" and within women's fiction "women's desire for each other overcomes their positioning as rivals and subverts their commodification" (59). Applying these arguments about homosocial desire to Burney's work complicates the rivalrous relationship between the women and makes clear that women, although taught to view each other as rivals, do recognize a value in each other not represented within masculinist logic. In fact, I would argue that the "romantic friendship" which defines the relationship between Cecilia and Mrs. Delvile can be read as emblematic of the sort of dangerous homoerotic female intimacy which eighteenth-century narratives work hard to recuperate into a normative phallocentric economy. ${ }^{103}$ I suggest that transforming a potentially subversive relationship into a conventional female rivalry is one of the ways in which this threat was managed. Yet Burney consistently resists this rivalry to emphasize a remarkably Sapphic desire between the two women which cannot be entirely effaced by the heterosexual love plot.

The first meeting between Cecilia and Mrs. Delvile is described as love at first sight, the narrator noting that Mrs. Delvile and Cecilia "saw in each other, an immediate prepossession in her favour, and from the moment that they met, they seemed instinctively impelled to admire" (155). Even Mortimer acknowledges they "seem bornfor each other" (518). Cecilia recognizes and declares her love for Mrs. Delvile long before she identifies a desire for Mortimer. Mrs. Delvile's "air, figure, and countenance instantaneously excited" (154), whereas even after several meetings Cecilia is still referring to Mortimer as "her friend the white domino," (152)—i.e., the man of no 
character. When forced to choose between Mrs. Delvile's approbation and Mortimer's hand, over and again Cecilia declares her primary attachment to the mother. For example, "she resolved to commit the whole affair to the will of Mrs. Delvile, to whom, though under no promise, she now considered herself responsible" (646). Accepting Mrs. Delvile as a model, she tells her: "I will be ruled by you wholly; I will commit to you everything" (658). Later, she says of her obligation to Mortimer, "I will make him no promise; to Mrs. Delvile alone I hold myself bound" (692). Although bound by no promise to either, she nevertheless makes priority her relations hip with Mrs. Delvile. Their relationship, in fact, resembles the marriage contract, even supercedes it. She privileges a contract with his mother over their own wedding vows, regarding her promise to Mrs. Delvile "as sacred as one made at the altar" (813). The passionate embraces, sighs, and agitations both express when in the company of each other indeed resembles romantic, if not sexual feelings. The potential of these feelings to disrupt the heterosexual matrix demands that Mortimer act as conduit of their desire.

The novel's "Contest" chapter is, without a doubt, the pinnacle scene of the book-as noted by Burney. I suggest that it is during this scene that the rivalry between Cecilia and Mrs. Delvile, otherwise masking their homoerotic desire for each other, comes undone. Instead, it quickly becomes apparent that the real rivalry is between Mrs. Delvile and her son for Cecilia. Perhaps most importantly, Cecilia drops out of the “contest," repeatedly silenced by both mother and son, as well as by her own anxieties. Of course, as already noted, Cecilia's role as female exemplar precludes her from actively fighting with Mrs. Delvile. However, her exemplary silence enables Burney to emphasize the competitive tension between Mother and Son for Cecilia. 
At the beginning of the chapter, Cecilia receives a letter from Mrs. Delvile who laments that she has not been able to get Mortimer to accept Cecilia's refusal of marriage. Mrs. Delvile thus requests that Cecilia meet both mother and son so as to "bear with your own lips to confirm the irrevocable decision" (669). Mrs. Delvile's choice of language throughout the letter explicitly indicates her belief that she and Cecilia are allied. She says, for example, "our work is still unfinished" (668) and tells her, "whatever you determine, be sure of my concurrence" (669). Simultaneously, however, the letter suggests a self-reflexive concern that Mrs. Delvile is not quite convinced of Cecilia's loyalty. Thus, her words "we [Mortimer and Mrs. Delvile] will wait on you together" (669) imply that Cecilia's heart and hand are still up for grabs, and that both Mother and Son will meet Cecilia with the intent to offer suit.

Indeed, the "Contest" scene reads like the dual wooing of Cecilia. When Mortimer arrives he tells his mother, "I come not to release, but to claim her!" (671). Mrs. Delvile, however, also demands to "claim her attention" (673). What ensues is a vicious struggle for Cecilia's attention, and ultimately her very real hand. Significantly, throughout the scene, both Mortimer and Mrs. Delvile offer arguments in their own favor, while Cecilia sits passively by. When she does attempt to talk, Mortimer and his mother interrupt her and then demand her silence. However, although both tend to treat Cecilia as an object, I suggest that Burney constructs their arguments so that Mrs. Delvile's "wooing" of Cecilia is both more logical and more genuine than her son's.

Mortimer's argument in favor of his "claim" to Cecilia rests primarily on proprietary assumptions bound up in the misogynist marriage market under fire in the late eighteenth-century. While Mrs. Delvile wants only to "claim" Cecilia's "attention," 
Mortimer wants to claim her in her entirety. He offers three evidences of his right to ownership: "the consent I obtained from you [Cecilia] to be legally mine, the bond of settlement I have had drawn up, and the high honour you conferred on me in suffering me to lead you to the altar" (673). Mortimer's desire to make her "legally" his flies in the face of her desire to be independent and his reference to the legal documents he has drawn up underscores what she has suffered at the hands of another legal document, her uncle's will. To accept Mortimer's conditions of marriage is to accept her status as commodity; it is no wonder that he would have had to lead her "suffering" to the altar.

And suffer she has, so much so that rather than reminding her of any passion she might feel for him, Mortimer can only suggest that if she does not have an "aversion" or a "dreadful and horrible antipathy" to him, or does not "hate or abhor" him—-then she should marry him. In other words, she should marry him not because she loves him, but because she does not detest him. It is a pathetic suit, indeed.

Mortimer also relies on some fairly underhanded tactics to convince Cecilia to be his. As he does earlier in the novel, he attempts to blackmail her into submission by suggesting that to marry him is less of an impropriety than to break her vows to him. He is delighted when he senses that the embattled Cecilia is yielding to his flawed logic, as she cries out "[E]very way I now turn I have rendered myself miserable" (673). Mortimer's success is Cecilia's misery; he has beaten her down, convinced her that there are no other alternatives.

Mrs. Delvile's “wooing” of Cecilia, although equally cunning, is nevertheless more logically and morally sound. As noted, Mrs. Delvile words her letter to Cecilia so as to prepare her as a ready ally. In fact, Mrs. Delvile and Cecilia enter the room together 
where Mortimer is waiting, and "Mrs. Delvile, advancing before her son,...endeavor[ed] so to stand as to intercept his view of [Cecilia]" (671). In this respect, she not only implies prior ownership, but protects Cecilia from his objectifying gaze. She then helps the trembling Cecilia to a seat and strategically sits beside her. Her bodily actions and physical positioning signal to her son her prior claim to Cecilia; moreover, at least in the beginning, she appears cool and confident of Cecilia's loyalty, much to her son's distress. Mrs. Delvile, admittedly acting in part out of selfish interests, does offer to Cecilia a more participatory role in the union she proposes. Although defending Cecilia's right to speak so as to deny Mortimer, Mrs. Delvile conveniently silences Cecilia when she sees her wavering. Yet unlike the son, Mrs. Delvile only wants to "claim" Cecilia's attention, and to allow her "to hear... so only can she judge what answer will reflect on her most honour" (673). Mrs. Delvile's argument is always that Cecilia should judge for herself, even if she is attempting to coerce Cecilia's compliance. Hence, she is more successful with Cecilia. Her language is one of choice and reason.

Moreover, Mrs. Delvile makes a valid argument when she suggests that her son's passionate defiance of social custom is potentially dangerous. Identifying strongly with Cecilia's embattled position, Mrs. Delvile is all too aware of the limits of female agency. Her argument is that Cecilia is, in fact, too good for Mortimer who is all too ready to cast off his family and his obligations. She quite rightly recognizes that Mortimer's defiance of social custom has not been reasoned out, but is instead the result of "mere self gratification" (676). He is "blinded...by passion" (676). Mrs. Delvile's suggestion that Mortimer doesn't deserve Cecilia is, of course, underscored by what the reader already knows and believes of Mortimer's flaws. This is not to say that Burney does not also 
believe, as Mortimer does, that the social customs precluding his marriage to Cecilia are in need of repair. Nevertheless, to throw off these customs rashly, as Mortimer plans to do, is to overlook the necessity of certain social customs. It is, in other words, to become like Mr. Belfield, the novel's other son, who having “determined to quit [the world] for ever" by living in a cottage in the wilderness invites the readers' disdain and ridicule. Hence, Mrs. Delvile's worldview is more reasonable, if more cynical. No doubt, Mortimer recognizes the truth of Mrs. Delvile's claim that his "heart will throb with secret shame and approach, when wished joy on [his] marriage by the name of $M r$. Beverly?' (677). Mrs. Delvile helps Cecilia to recognize Mortimer's own vanity. Rather than forcing her compliance, she wins her over with the language of reason.

Seemingly "conquered" by his mother, Mortimer storms out (677). However, when he sees Cecilia tottering on the stairs, overcome with silent emotion, he runs to her, offering support. Yet Cecilia turns away from him and, significantly, walks again toward the parlor where Mrs. Delvile is anxiously watching. "'Give me your hand, my love,", Mrs. Delvile offers, and then, followed by Mortimer, helps her to a chair where Cecilia then "hid her face against Mrs. Delvile" (679). Again, Mrs. Delvile maintains female intimacy with Cecilia, but whereas as the beginning of the scene Mrs. Delvile had strategically positioned herself next to Cecilia, here Cecilia clearly chooses Mrs. Delvile and refuses Mortimer, who continues to try to force himself on her. When Mrs. Delvile suggests to Cecilia, "Miss Beverly, we will both leave him" she is suggesting voluntary female companionship.

The symbolic horror of what their union represents is crystallized for Mortimer, who up to this point has complied with his mother. When Cecilia gets up to leave with 
his mother, Mortimer rushes in between them, exclaiming to his mother, "I cannot let you go; I see your intention, I see your dreadful purpose; you will work on the feelings of Miss Beverly, you will extort from her a promise to see me no more!" (680). Mortimer is afraid that Mrs. Delvile will take Cecilia from him forever; moreover, "the intention [and] dreadful purpose" Mortimer recognizes, at least unconsciously, is the threat their homoerotic desire for each other poses to the heterosexual matrix. It is thus that "[t]his moment appeared to Delvile decisive; and casting off in desperation all timidity and restraint, he suddenly sprang forward, and snatching the hand of Cecilia from his mother, he exclaimed, 'I cannot, I will not give her up!' (680).It is significant that Cecilia's hand, given voluntarily to the mother, is snatched by the son.

It is not the first time Cecilia has given her hand to Mrs. Delvile, as Mortimer well knows. Earlier in the novel, after having explained her reasoning to Cecilia concerning her relationship with Mortimer, Mrs. Delvile asks Cecilia in parting, "You will not, then, give me your hand?" (642). Cecilia complies, if a bit reluctantly. In the next chapter, Mortimer is disturbed by Cecilia's change of heart and asks,

"Oh What," cried Delvile, endeavoring to take her hand, which she hastily withdrew from him, "what does this mean?... Why refuse me that hand which so lately was the pledge of your faith? Why will you not open to him your heart?...Oh why, giving him such exquisite misery refuse him the smallest consolation?" (644).

"What consolation," cried the weeping Cecilia, "can I give? Alas! It is not, perhaps, you, who most want it!--" (644-45) 
The scene is symbolically loaded. Although she implies that she herself is in need of greater consolation, we cannot forget the scene only pages earlier in which Mrs. Delvile lamented the "misery of domestic contention" which only Cecilia can rectify. Cecelia's greater sympathies are with Mrs. Delvile. Further, Cecilia's reply is also to the first part of Mortimer's question— "why refuse me that hand...?" The answer is because it is not he, but his mother, who most wants it. Mrs. Delvile has made the more passionate proposal. Having already given her hand to his mother, she cannot give it to him.

Further, I argue that Burney uses the narrative of romantic friendship, conventionally situated within a mother-daughter relationship, to make room for an articulation of female homoerotic desire. ${ }^{104}$ Throughout the text Mrs. Delvile refers to Cecilia as a surrogate daughter. Mortimer notes, "Miss Beverly alone seems born to be her daughter" (569), and on more than one occasion Mrs. Delvile wishes aloud that she had a biological daughter like Cecilia. More significantly, Mrs. Delvile calls Cecilia "daughter of my mind" (651). Yet it is immediately made clear that Mrs. Delvile only calls Cecilia "daughter" because she lacks another term to describe her feelings for her. She exclaims, "Oh Daughter of my mind!...what tie, what connection, could make you more dear to me?" (651). The closest approximation Mrs. Delvile can arrive at to define their relationship is mother and daughter, yet the dialogue between them and the narrator's description of their physical intimacy makes clear over and again their erotically charged feelings for each other. Thus, when Mortimer snatches Cecilia's hand from his mother's, she is devastated: "Grief and horror next to frenzy at a disappointment thus unexpected...rose in the face of Mrs. Delvile, who, striking her hand on her forehead, cried, 'My brain is on fire!' and rushed out of the room." Moments later they 
find her, "extended on the floor, her face, hands and neck all covered with blood" (680). No doubt, one could read her reaction as the material effect of Mortimer's symbolic separation from her, a terrible re-birth, tearing forth from the mental womb within which she has tried to contain him. However, a complementary reading suggests that it is the "daughter of [her] mind" which has caught on fire, for it is that "daughter's" hand which has been taken from her. In other words, their homoerotic bond has been sacrificed on the altar of compulsory heterosexuality. ${ }^{105}$ Importantly, Burney's "Daddy" Crisp had requested that she edit out the scene within which Mrs. Delvile bursts a blood vessel. In response, Burney argues that the chapter is the very reason for which she wrote the novel: "I must abide by its reception in the World, or put the whole behind the Fire" (178). ${ }^{106}$ That Burney envisioned this "contest" scene as the climax of the novel encapsulates what I argue is its feminist drive - a contest between heterosexual and homoerotic desire-and an ultimate privileging of the latter.

Resolution, however, is not simple for Burney. To emphasize the value of female friendship, to force the reader to feel fully the pain caused by sacrificing female intimacy, the narrative defers the union between Mrs. Delvile and Cecilia. Just as Mrs. Delvile goes mad when Cecilia is snatched from her by Mortimer, Cecilia's own ensuing madness is precipitated by her belief that she has been parted forever from her friend because of her union with Mortimer. Her ennui throughout the wedding preparations and ceremony evidences her deteriorating state. When her friend Albany comes to see her during these preparations, he suspects that her youthful innocence is gone. Cecilia replies, "It is but too true, I have lost her for ever" (703). However, I posit that she does not 
lament the loss of innocence, as Albany believes, but the forfeiture of her dearest friend, Mrs. Delvile.

After the wedding, Cecilia's senses entirely unravel, seemingly because she fears Mortimer, having misread her relationship with Belfield, will die dueling with him. I suggest, however, that Mortimer once again merely stands in for the real source of her despair. Having lost her senses, Cecilia wanders into a pawnshop where she collapses. Significantly, the newspaper advertising her location says only that she "talks much of some person by the name of Delvile" (901), leaving ambiguous for which Delvile, mother or son, she longs. The narrative, however, has made clear that Cecilia's real passion is for the mother. In fact, women in eighteenth-century fiction are conventionally reduced to madness when they lose female community. Says Janet Todd of fiction of the period, "Women go insane when friends fall away...each woman goes mad when the solacing female presence is denied..." (Women's 409). Denied each other, Cecilia and the still ailing Mrs. Delvile suffer separately.

Cecilia is only fully cured from her madness when she reunites with Mrs. Delvile, the two embracing in a "most rapturous fondness" (938) that starkly contrasts with both Cecilia's mechanical motions during her anti-climactic wedding and her reunion with Mortimer. Mortimer spends most of Cecilia's recovery time outside her bedroom rather than inside it; it is only when they travel abroad (to visit Mrs. Delvile!) that Cecilia leaves the confinement of the bedroom. Moreover, in the closing pages whenever Cecilia speaks of her happiness, it is always first with a reference to Mrs. Delvile's presence, only secondarily followed by an acknowledgement of Mortimer. For example, as she recovers she notes first Mrs. Delvile's care, and only afterwards Mortimer: "the 
impression of her sorrows gradually wore away, from [Mrs. Delvile's] kind and maternal cares, and from the watchful affection and delighted tenderness of her son" (938). She repeats this example in the final paragraph: "The upright mind of Cecilia, her purity, her virtue, and the moderation of her wishes, gave to her in the warm affection of Lady Delvile, and the unremitting fondness of Mortimer, all the happiness human life seems capable of receiving..." (941). The narrative may culminate in marriage, but it privileges female friendship.

\section{Cecilia and Henrietta: The Threat of Betrayal}

Thus far I have focused almost exclusively on the rivalry between Cecilia and Mrs. Delvile, but what I have noted of their relationship holds true, as well, for Cecilia's relationship with Henrietta. Cecilia never contests the impropriety of Henrietta's desire for Mortimer. The narrator details Cecilia’s logic: "however precarious was her own chance with young Delvile, Miss Belfield she was sure could not have any: neither her birth nor education fitted her for his rank in life..." (352). Nor does Cecilia think of including her in her intimate circle with Mrs. Delvile. Arguably, just as Mrs. Delvile has internalized a system of patrilineage, desiring what "The Father" desires, so too does Cecilia desire "paternal" approval. Mrs. Delvile believes in her inherent superiority to Cecilia just as Cecilia never questions Henrietta's inferiority to herself. In fact, "her pity...for Miss Belfield was almost wholly unalloyed by jealousy; she harbored not any suspicion that she was loved by young Delvile, whose aspiring spirit led her infinitely more to fear some higher rival, than to believe he bestowed even a thought on the poor Henrietta" (351). Cecilia's pity really masks class condescension. 
Moreover, Cecilia's refusal to consider Henrietta as a serious rival clearly taints their friendship with certain inauthenticity, a lack of genuine communication as neither can declare to the other their true feelings. Social psychologists have suggested that the fear of betrayal always shadows female intimacy. ${ }^{107}$ Indeed, Cecilia debates whether or not to discuss with Henrietta their mutual feelings for Mortimer, but ultimately decides that such a confidence could be dangerous. She expresses concerns for Henrietta, asking herself, "Would it not be a kind of treachery to gather from her every thing, yet aid her in nothing? To take advantage of her unsuspicious openness in order to learn all that related to one whom she yet hoped would belong ultimately to herself...?" (352). Certainly, however, Cecilia must also be concerned about Henrietta's own potential treachery, acknowledged by the narrator:

Once, from the frankness natural to her disposition, she thought not merely of receiving but returning [Henrietta's] confidence: her better judgement, however, soon led her from so hazardous a plan, which could only have exposed them both to a romantic humiliation, by which, in the end, their mutual expectations might prove sources of mutual distrust. (353)

In watching out for Henrietta, Cecilia really safeguards her own secret. Thus, when Henrietta attempts to lay out her heart to Cecilia, Cecilia avoids her, instead "talking the whole time on matters of utter indifference" (353). Genuine conversation is interrupted by the threat of female rivalry, so that even though Cecilia swears that their mutual love for Delvile will "not then divide but unite us" (352), they are, indeed, alienated from each 
other. "Whether real or false," notes Straub of Cecilia, "romantic love is the snake in the garden of female friendship" (131).

It is only when their positions as rivals are made clear that Henrietta and Cecilia are finally able to share an authentic friendship. As in the triangulated relationship between Cecilia, Mrs. Delvile and Mortimer, once again Mortimer acts a conduit of desire between two women. Henrietta Belfield, on Cecilia's marriage to Mortimer, tells her she must leave her: "for married ladies I know are not to be trusted!" (811). She evidences a thorough internalization of the trope of female rivalry. Yet at the novel's end it is Henrie tta who stands by Cecilia's side as she struggles to recover from insanity; an impotent, petrified Mortimer can only watch.

Clearly Burney is writing against the conventions of the romantic love plot, even as her novel seems to uphold them. The degrees to which the women of the novel struggle to maintain relationships with each other effectively eclipses the source of their contention, so that what the reader sees is how unwilling they are to give each other up for the sake of a man. It is the conventions of a patriarchal ideology, the hollow trope of female rivalry with which they battle, for it is apparent that they are not ready to sacrifice each other. Thus, rather than severing female ties, female rivalry provides Burney an opportunity to emphasize the fierce passion the women feel for each other.

\section{Conclusion: The Women in Burney's Life}

I want to close by considering how Burney's personal encounters with female rivalry and a conflicted relationship with her stepmother may have affected her depiction of women's relationships in Cecilia. Doody's biography of Burney suggests that the 
death of her mother when she was only ten scarred her emotionally, compounded by feelings that she had been replaced in her father's heart by his new wife, Elizabeth Allen. Burney's treatment of Cecilia's substitute- mother figure no doubt says much about her vexed feelings about her stepmother. In particular, Burney's depiction of Mrs. Delvile's jealous guarding of her son is reminiscent of Elizabeth Allen Burney's relationship with Dr. Burney. Burney's letters and journal entries depict her stepmother as jealous of Fanny's relationship with Dr. Burney, as well as the close friendships between her children and stepchildren. Indeed, Hemlow notes, the children often ganged up against their ill-tempered mother and even shared in jokes at her expense with company-a form of "sedition” of which Mrs. Burney was rightfully suspicious. ${ }^{108}$

Fanny notes the problems she is experiencing with her stepmother during the writing of Cecilia. Away from home in November, 1781 and constantly deterred from working on her novel, she longs to return home, but acknowledges the "many interruptions from ill management, inconvenience, \& ill nature I must meet with when I go" (qtd. in Hemlow 146). In another letter she revels in a friend's scathing caricature of Elizabeth Allen, as "a nasty old Cat," "an old sow," and "an indelicate Beast" who spends her time "tiffing herself up for a gay young thing" (Journals and Letters 185). As is typical of strategies of female rivalry, Burney relies on code-names when referring to her stepmother in letters to friends, and focuses on her stepmother's lack of intelligence and inferior beauty. Importantly, however, she rarely attacks her stepmother outright, instead offering criticism of her from the mouths of others. After all, even in a diary meant for "Nobody" it is inappropriate for a woman to engage actively in aggression against another woman. 
Fiction no doubt offered Burney another channel for her aggression. Margaret Doody has suggested that the ridiculous Madame Duval of Evelina fame is a caricature of the reviled stepmother. Nevertheless, Burney is self-reflexive as she satirizes Madam Duval. Says Doody, "While imaginatively releasing her own hatred of her stepmother, Burney points out that women's hatred of other women is useful to the most antipathetic concerns and desires of males. A woman condemning any other woman may reflect male hatred and support masculine irrational control over all womankind" (55). Similarly, Burney's depictions of "ridiculous" women in Cecilia allows her to satirize the follies and foibles of the real women with whom she came into contact and often described in her journals; yet as I have argued, her criticism is less of the women than the society which has encouraged their behavior. Mrs. Delvile's fetishistic guarding of her son is explained as the effect of her delimited sphere of agency in a patriarchal society; arguably, Elizabeth Allen's jealous behavior is also implicitly excused. If she spends her time "tiffing herself up for a gay young thing," as Burney’s letter suggests, then perhaps she does so because, as custom demands, women are primarily valued for their youth and beauty. Of her caricature of Mrs. Delvile, Burney writes,

I meant in Mrs Delvile to draw a great, but not a perfect character: I meant, on the contrary, to blend on paper, as I have frequently seen blended in life, noble and rare qualities, with striking and incurable defects. I meant, also, to shew how the greatest virtues and excellencies, may be totally obscured by the indulgence of violent passions, and 
the ascendancy of favourite prejudices. (Journals and Letters 178)

By this judicious logic, perhaps even Elizabeth Allen's beha vior is understandable, if not excusable.

Moreover, I suggest that writing Cecilia perhaps signifies Burney's desire to repair her vexed relationship with her stepmother. In her introduction to The Wanderer Burney recounts her fifteenth birthday when, compelled by shame, she burned all her manuscripts, to include "The History of Carolyn Evelyn," her first draft of Evelina:

I committed to the flames whatever, up to that moment, I had committed to paper...and-well I remember! Wept, with tender partiality, over the imaginary ashes of Caroline Evelyn, the mother of Evelina.

The passion, however, though resisted, was not annihilated; my bureau was cleared; but my head was not emptied; and, in defiance of every self-effort, Evelina struggled herself into life. (qtd in Doody 36)

The recollection is significant for it suggests not only the vexed position in which she was placed as a young girl who desired to write novels, but also because it implies her investment in repairing a mother/daughter relationship. Doody asks of this scene, "Was the bonfire perhaps an unconscious piece of magic, the expression of an unrecognized hope that if Fanny were 'good' enough and sacrificed the 'good mother' Caroline Evelyn, her father in reciprocation would sacrifice Mrs. Allen?” (37). Perhaps. But I suggest a slightly different interpretation. I argue that Elizabeth's failing as a stepmother is not 
necessarily the result of her "stealing" Burney's father from her. Instead, her failing is in refusing to be the kind of female friend and maternal figure Burney so desperately needs - the kind Cecilia finds in Mrs. Delvile.

Indeed, in Cecilia Burney relives so as to rewrite the immolation of her childhood. I argue that the "fire" in Mrs. Delvile's brain during the crucial conflict scene is meant, according to social dictum, to destroy the mother-daughter bond. However, the scene lucidly demonstrates the intense desire of the women to be together and the ravaging effects of their separation from each other. This revelation, I suggest, is the reason why Burney refuses to cut this scene. To please "Daddy" Burney she might have sacrificed the mother/daughter bond in Evelina, but she will not toss Cecilia and Mrs. Delvile onto the funeral pyre to pacify "Daddy" Crisp. In a letter to Crisp, who deplored the scene, she writes, "The conflict scene for Cecilia, between the mother and son, to which you so warmly object, is the very scene for which I wrote the whole Book! And so entirely does my plan hang on it, that I must abide by its reception in the World, or put the whole behind the Fire" (Journals and Letters 178). In other words, she would rather burn the entire text, including its conventional close in marriage, than erase the scene within which Mrs. Delvile and Mortimer fight for Cecilia's hand. This scene is crucial because it enables her to express the importance and relevance of women's bonds with each other. Further, it allows her to suggest the terrible effects of separating women from each other over something so trivial as a man, or worse yet his name-no more than an empty signifier of male privilege. In as much as Mrs. Delvile stands up to Mortimer and resists her own self-effacement, Burney stands up to both her "Daddies" and to the patriarchal conventions they represent. 
In Burney's rewriting of the conflagration, although Cecilia's bond with Mrs. Delvile is temporarily destroyed, it is not annihilated; Mrs. Delvile's head is not emptied. There are no ashes to weep over for, as the novel's close implies, the mother-daughter bond struggles itself back into life. Unlike Evelina, for whom Caroline is lost forever, Cecilia gets to be with Mrs. Delvile at the close of the novel. Thus Cecilia offers a corrective to the death of Caroline Evelyn. The homonymic names Delvile and Evelyn suggest that Cecilia works to raise from the dead Caroline Evelyn, to unite in Mrs. Delvile and Cecilia the female union engulfed in her earlier work and for which she herself longed.

Burney finally found that friend in Hester Thrale, who some have suggested as a model for Mrs. Delvile. Their intimate relationship, however, was equally if not more vexed, and the two experienced nearly thirty-one years of estrangement following Thrale's scandalous elopement with her children's music teacher, Gabriel Piozzi, in 1784. In this case, Henrietta's fear about Cecilia proved all too real for Burney. Thrale, ignoring Burney's pleas that she reconsider her decision, went so far as to return Burney's last letter to her, unopened. In it, Burney had begged her to "reflect a little before this fatal final answer with which you terrify me is given! Children-Religion, Friends, Country, Character,--What on Earth can compensate the loss of all these?" (Journals and Letters 204). Clearly Burney positions herself, as Thrale's dearest friend, in direct competition with Piozzi. Ultimately, Thrale sacrifices this precious female intimacy for heterosexual love. Burney, unable to forgive her friend for having disgraced herself in the public's eye severed their friendship. After all, to maintain a friendship with Thrale would endanger her own reputation and possibly put her out of favor with men 
like Dr. Johnson. In fact, Burney recounts an encounter with Dr. Johnson in which she is arguably trying to feel out his sentiments about Thrale, perhaps depending on his response to guide her own. Referring to her own encounter with Thrale's daughter, Queeney, a day earlier, Burney timidly asks, "Do You ever, sir, hear from her mother?" Johnson responds vehemently, "If I ever meet with one of her Letters I burn it instantly. I have burnt all I can find. I never speak of her, and I desire never to hear of her more. I drive her, as I said, wholly from my mind" (Journals and Letters 205). So, too, did Burney drive her from her mind. Although in Cecilia, Burney might be able to understand and even empathize with Mrs. Delvile's imperfect character and violent passions, in real life, there could be no such allowance. Mrs. Thrale's error in allowing “so great an ascendance of passion over Reason" (Journals and Letters 203) was inexcusable. Thus, if Thrale had sacrificed Burney to heterosexual love, Burney sacrificed Thrale to patriarchal approval, to class egotism, and to, no doubt, her own injured pride at coming in second-place.

It is easy to condemn Burney's conservatism and level charges of hypocrisy at her for having written a fiction attacking the very social customs to which she appears to so resolutely cling. Yet her journals and letters suggest a degree of self-reflexivity about her own dogmatism. Although the once dear friends were not reconciled (at least partially) until 1815, they did encounter each other on at least two separate occasions noted by Burney. The first was in 1790 at an assembly. Burney's brief reference to the meeting as a "long-wished, long-dreaded interview" (Journals and Letters 299) suggests regret at her earlier decision. When she encountered her again on her way to Church a few months later, she says she "received exceeding great satisfaction," and the two pressed hands 
fondly. Burney says she was relieved to note that Thrale, too, seemed pleased. Moments later, however, Burney worried that someone might have witnessed the encounter: "I knew it would be disapproved that any connection should be renewed, beyond a courtsie" (Journals and Letters 300). Burney also writes that she was relieved no one had seen the meeting because other members of the church, and even the Queen herself, made fun of the way Thrale was dressed. Burney's fear of social approbation ultimately outweighed the genuine love she felt for Thrale.

Significantly, it was only with Piozzi out of the picture that Burney felt it was appropriate to attempt a reconciliation. Six years after Piozzi's death, Burney took the initiative to visit the still mourning Thrale. Says Burney on seeing Thrale for the first time in over thirty years,

I was moved, I own, strongly moved at her sight, by the remembrance of her former fondness, for such only is the word adapted to describe her fervent regard, and the unequalled eagerness with which she sought, struggled rather, to have me incessantly in her sight; but though my first impulse was ready to throw me into her arms, her frigid mein and manner soon chilled every feeling, and restored me to a composure on a par with her own.

(Journals and Letters 500)

Clearly Burney's feelings had not been abated by time. Significantly, she describes their affection for each other in earlier times as having been inadequately described by words. Yet tension remained, the two resorted to banal conversation and, on leaving an hour later 
a disappointed Burney consoled herself by suggesting that Thrale was cool with everyone. Burney met with Thrale again in November, 1816, and although the talk was lighter, Burney still describes their relationship as that of "two strangers" (Journals and Letters 505) and laments that "[a] stranger would have supposed we had met for the first time" (Journals and Letters 506). Yet as Burney left, she extended her hand to Thrale, who took it, and the two immediately embraced. Few words were exchanged, but the intensity of Burney's description echoes with both joy and regret. The two resumed a cordial correspondence, although never recovering entirely from their feud.

Forced apart by social custom, the two women, much like Cecilia and Mrs. Delvile, even when reunited, never truly enjoyed the kind of uninterrupted female intimacy they seemed to desire. Thus, Burney's depiction of female rivalries, and her pessimistic view of happy endings in the novel's close speaks to the very real terms and conditions of women's relationships with each other-and suggests another level of selfreflexivity about her own patriarchal complicities. Moreover, it makes painfully clear how inextricably entangled in social custom Burney finds herself; to reject social custom is to be ostracized like Thrale. Forced to choose between social approbation and her loyalty to Thrale, Burney turned her back on her friend and no doubt displaced onto her all the frustration and aggression meant for the patriarchal institutions making her choose. She may, in fact, have been all the more jealous of Thrale for having acted on passion, rather than socially dictated "reason." It was a choice Burney could never make—a choice, perhaps from her point of view, too sensible to make. Thrale's treason was thus felt all the more acutely; Burney was left behind, desperately trying to defend the institutions oppressing her, fighting valiantly to keep the castle walls secure. Of course, 
Thrale's unexpected happiness with Piozzi simply didn't correspond to what Burney has been taught to believe; thus it was only when Thrale was in mourning, dressed all in black, a shadow of her former self, that Burney allowed her back into her good graces. Their reunion was short-lived; Thrale died only five years later. 


\section{Chapter Four:}

\section{'Jealousies Without End or Common Sense’: Domestic Ideology, Romance, and Resistance in Maria Edgeworth's Belinda (1802)}

According to biographer Marilyn Butler, Maria Edgeworth explicitly rejected the notion that her novels performed any political work. Even in her Irish tales, Edgeworth stubbornly insisted that rather than positing a political view, her novels simply depicted life as it really was. ${ }^{109}$ Yet Edgeworth's works are highly politicized, peddling a domestic ideal which services a patriarchal, capitalist economy. Nonetheless, this chapter argues that Edgeworth never successfully submerges the voice of a self-reflexive feminist resistance to her own ideological alliances.

When the eponymous heroine of Belinda (1801) makes her public debut in London she is "exposed at once to the malignant eye of envy" (143). The ever rational Belinda, who has no "serious" views of marriage, rejects the games of courtship and its de facto rivalries. Even when a lock of another woman's hair falls from a book read by the man she loves, Belinda suppresses her emotion, rationalizing the disappointment: "Fortunately...I have discovered that he is attached to another, whilst it is yet in my power to command my affections" (139). Of course, her refusal to compete with other women, even for love, is part and parcel of her role as paradigmatic female. As Janet Todd has argued, late eighteenth-century fiction witnessed a back-lash against the earlier vogue of a high sensibility rooted in bodily sensation. In its stead emerged a more 
constrained heroine able to subordinate her passion to reason—to command her affections. $^{110}$

Certainly, Belinda provides readers an exemplary model of domestic femininity, resisting commodification and insisting on non-negotiable personal value located outside a material economy. ${ }^{111}$ Her refusal to compete with other women demonstrates a rejection of both the trade in women and the marketplace logic to which that trade is inextricably linked. In rejecting the logic that pits women against each other as rivalrous commodities, ${ }^{112}$ Belinda, character and novel, also contests the ubiquitous trope of female rivalry pervading traditional courtship narratives. Yet Belinda's very exemplarity isolates her from other women as she vies with them for the readers' sympathies. To this end, Belinda reproduces a conventional and masculinist good girl/bad girl dyad, ironically dependent on the trope of female rivalry. Moreover, the domestic bliss the "good girl" works to support arguably does little more than replace more explicitly coercive forms of patriarchal authority, therein, stabilizing the status quo.

However, I posit that Edgeworth's novel also undermines the moral economy it supports, and in as much resists the patriarchal complicity of which she is too often accused. ${ }^{113}$ Belinda is dizzyingly rife with contradiction, at one moment seeming to support a radical feminist agenda, at another unswervingly loyal to a patriarchal ideology. Mitzi Myers uses the term "bilinguality" to make sense of these contradictions. Says Myers, "bilinguality...is not the textual sign of timidity or patriarchal complicity. Rather, like the warrior woman who donned manly attire to gain access to forms of agency, experience and achievement otherwise available only to men, the authorial impersonator unsettles the status of behaviorally encoded sexual difference" (134). I agree that 
Edgeworth's attempts to work through tensions created by the double-bind in which she is placed as woman and writer in the eighteenth century results in a form of "doublespeak"; however, I find the term "warrior" an uneasy descriptor of a woman who, as Butler's biography makes clear, was so deeply attached to her father and so dependent on his praise, as well as intensely conscious of social decorum. Neither does bilinguality sit well with me. While I think there are at least two voices at work in her texts, I do not think they are in easy co-existence, as bilinguality suggests; nor do I think that the "conservative" side of Edgeworth is really a mask for radical feminism, although, as I will suggest, she certainly does try her hand, rather successfully, at impersonation. Belinda is clearly at odds with itself. I argue that Edgeworth's text evidences at least two competing voices, and it is their unresolved tension, rather than a fluid bilinguality, that surfaces again and again. Edgeworth's self-reflexivity about the prescriptions of the romance plot, the impossibility of domestic utopia, and her own role in manufacturing a fictional reality cannot be entirely repressed. Further, like her predecessor, Frances Burney, she refuses to suture over the ideological gaps opened up by these moments of self-reflexivity. ${ }^{114}$ Moreover, I do not feel that, for Edgeworth, the sides are equally weighted; in the end, her feminist inclinations tip the scales in favor of feminist revision. Edgeworth relies on the trope of female rivalry to imagine a domestic utopia capable of displacing class tensions brought about by changes in the eighteenthcentury market; however, she also negotiates ways to turn that trope back on the patriarchal interests. 


\section{Good Girl/Bad Girl Dyads and a Moral Economy}

The novel's drive to privilege one version of femininity as natural and therein "good," over another marked as artificial and therein "bad," is clearly evidenced in a scene within which Belinda and the woman she works to reform compete, if only implicitly, for a man's approval. Lord Delacour has refused to grant Lady Delacour money for a new coach and horses, adding fuel to the flame in an already troubled marriage. Belinda attempts to mediate by suggesting to Lord Delacour a truce. When she approaches him, he begins to explain his position on the argument, reminding her, "I am not a man to be governed by a wife" (155). Belinda, however, stops him, saying she would "rather hear of the end than of the beginning of quarrels" (155). He responds to mild-mannered Belinda: "I wish you could make lady Delacour of your taste—-she does not want sense — but then (I speak to you freely of all that lies on my mind, miss Portman, for I know-I know you have no delight in making mischief in a house)--between you and me, her sense is not of the right kind" (155). Belinda's "sense," which is the "right" kind, is clearly contrasted to Lady Delacour's. However, the right kind of sense no more signifies Belinda's use of logic or reason than Lady Delacour's. In fact, although Lord Delacour does pay Lady Delacour's debt for the horses, Belinda does not get him to do so by justifying Lady Delacour's extravagances. Rather, Lord Delacour prefers to give the money to Belinda because she is nice and doesn't try to outdo him in a battle of wits. ${ }^{115}$ Belinda has earlier recognized that Lord Delacour's resistance to his wife's pleas stems from a "fear of being, or of appearing to be governed by her ladyship" (138; emphasis mine). Because Belinda does not openly challenge his authority, he allows her desires to govern his choices. In fact, when he offers Belinda the banknotes, she directs him to 
instead give the money directly to his wife. Watching her exit the room, Lord Delacour muses, "How lightly she goes, on the wings of good nature!...I can do no less than follow her" (156). Although he intends only to "follow her" to his wife's dressing-room, the suggestion is clear: she will lead him to moral redemption.

Lady Delacour, baffled by Belinda's success with Lord Delacour, assumes that Belinda has seduced him. She reasons, "She never coquettes...Is this natural? Absolutely unnatural; artifice! Artifice! To contrast herself with me in lord Delacour's opinion is certainly her object" (182). Belinda, of course, possesses no such motive, although her author does. Indeed, Edgeworth intends to contrast Belinda's superior moral economy to Lady Delacour's materialism. Belinda makes the "right" kind of sense, succeeding where Lady Delacour has failed, not because she is more sexually desirable as Lady Delacour suspects, but because she is more morally and socially authoritative. Lord Delacour's desire is for Belinda's moral instruction and for the new value-system she represents, one which does not present a direct challenge to male authority. Subject to women's moral authority, men don't have to fear the appearance of being governed by women; they are each the head of separate, distinct, though inextricably linked spheres. In as much, Belinda represents a version of femininity able to reform both the household and, through its male head, behavior in the public sphere without ever appearing to possess agency. Contemporary readers might recognize in Belinda the famed "angel in the house" who, by mid-nineteenth century, conventionally floats on "wings of good nature" inside ubiquitous domestic utopias. At the turn of the century, however, Belinda represents a feminine ideal not yet fully established. Explains Eve Tavor Bannet, the function of exemplary female characters in enlightenment domestic fiction "was not to reflect social 
practices but to intervene in practice by offering a constructed and embodied ideal...as a model for readers' imitation, as a motive for their actions and as an object of their desire" (61). ${ }^{116}$ In contrast, negative exempla ("bad" girls) model behaviors meant to be rejected and/or reformed. The historicity of these versions of femininity should not be overlooked. Clearly, the novel negotiates what James Thompson sees as an eighteenthcentury crisis in the concept of value brought on by emerging capitalism. ${ }^{117}$ The "bad" women of the novel, Mrs. Stanhope, Lady Delacour, and Harriet Freke represent not only competing versions of femininity, but embody various anxieties raised by a quickly expanding market economy. ${ }^{118}$ Belinda's exemplarity, the set of values she embodies, is class specific and designed to assuage these anxieties.

The use of a model woman to negotiate such tensions is not novel in the late eighteenth-century. As Armstrong has suggested, Richardson's Pamela works to reform the aristocratic Mr. B through love and Richardson's Clarissa is a Christian martyr, leaving behind a legacy which rejects a sexual economy and embraces a spiritual economy. What is new about Belinda is her use of reason rather than religious doctrine to negotiate class and gender tensions. Rather than displacing public contests onto a private contest between a man and a woman, Belinda displaces these struggles onto the site of women's relationships with each other. Indeed, to some extent Belinda works to reform her suitors, Vincent and Hervey, and their corresponding ideological systems, through their desire for her. However, the greater emphasis of the novel is on female homosociality and, more specifically, female rivalry.

Supplementing existing examinations of class tensions in Belinda, ${ }^{119}$ I argue that anxieties about the problems inherent in the market system are negotiated through the 
good girl/bad girl dyad that controls much of the narrative. The good girl becomes the moral anchor of the ideal family, stabilizing the conditions necessary for the maintenance and prosperity of an emerging middle-class. ${ }^{120}$ In contrast, the negative exempla of Belinda are "bad girls" because, dissatisfied with domesticity, they seek rewards in the public sphere. Belinda's narrative goal is the ultimate recuperation of these "bad" bodies into a moral economy, one within which their internal value is stabilized, protected from the fluctuating standards of the market.

In domestic fiction, the home becomes the site within which these bodies are contained. In turn, the home, as it is idealized, provides a comforting haven away from the tensions of a corrupt public sphere; at the same time, the very existence of an uncontaminated "home" works to authorize the exploration of male desire outside its walls. A "home" means there is always a safe place to which men can return for redemption, and always a vantage point of "truth" from which the rest of the corrupt world can be judged. Because of its ideological necessity, the "home" as it is idealized must be protected; conduct-books and domestic fiction grant women this role. From an ideological viewpoint, it makes perfect sense; women, clamoring for agency in the midst of a European enlightenment, are pacified when assigned a certain moral authority still informing gender politics today. The erasure of a history of sexuality, i.e, the circulation of the largely uncontested myth of woman's intimate connection with the home has, like Peter's pumpkinshell of nursery rhyme lore, for centuries "kept her very well."

The impulse of the novel, then, is consistently to demonstrate not just the moral superiority of Belinda, but the naturalness of this model; that is, all women can achieve this ideal because this ideal already exists within them—-they simply need to find their 
way back "home" to their true selves. Thus, the "bad" women of the novel are depicted as tainted versions of that ideal who won't rest until they have corrupted all other women in their path. The novel begins with the exchange of Belinda between two "bad" women. In Chapter One the reader learns that Mrs. Stanhope, "maneuvering with more than her usual art," has delivered Belinda into the hands of the aging female gallant, Lady Delacour, to whom she entrusts her marriage prospects. Within days following her arrival, Mrs. Stanhope sends Belinda a letter urging her to play her proverbial cards wisely in the marriage market. Encouraging Belinda to see her prospects for marriage as intensely and inherently competitive, she cautions her against behaving like other "players":

I used to see multitudes of silly girls, seemingly all cut out on the same pattern, who frequented public places day after day, and year after year, without any idea further than that of diverting themselves, or of obtaining transient admiration....[N]othing to my mind can be more miserable than the situation of a poor girl, who, after spending not only the interest, but the solid capital of her small fortune in dress, and frivolous extravagance, fails in her matrimonial expectations, (as many do merely from not beginning to speculate in time). She finds herself at five or six and thirty a burden to her friends, destitute of the means of rendering herself independent (for the girls I speak of never think of learning to play cards).... (8) 
This initial letter is clearly evidence of the sort of "double-speak" Myers identifies, Mrs. Stanhope a figure of feminist resistance, and, at the same time, a dangerous woman who uses her authority to mislead her pupils. On one hand, Mrs. Stanhope's suggestion that Belinda stand apart signals a keen awareness of the marriage market's tendency to obscure internal value. She astutely recognizes the misogynistic practices of the marriage market, within which matrimony is high-risk and rarely profitable for women who inevitably must forfeit much more than their hand. Her advice echoes the sort of protofeminist arguments circulating in eighteenth-century literature, perhaps most famously in Mary Wollstonecraft's Vindication of the Rights of Woman but, as I have argued in my earlier chapters, also present in the works of Scott and Burney. Her insistence that Belinda set herself apart from other "pattern" women demonstrates one way in which Edgeworth uses the good girl/bad girl binary to dis tinguish Belinda from the type of women readers should avoid as well as avoid becoming. These women are silly, spendthrift coquettes, focused only on the moment with no eye toward their future. They burden, rather than support the economy. Belinda, and Edgeworth's readers, can learn from their mistakes.

Yet Mrs. Stanhope is no authority figure on proper femininity—or, at least, not one whom should be obeyed. Mrs. Stanhope's letter suggests a radical demand for female agency, criticizing the giddy young girls for not learning to play cards whereby they might gain economic independence. Rather than evidence of Edgeworth's feminist inclinations, Mrs.Stanhope's advice, like that later offered by Lady Delacour and Harriet Freke, is meant to be rejected by both Belinda and Edgeworth's female readership as immoral. Most obviously, Mrs. Stanhope's suggestion that women increase their fortune 
by gaming evidences her moral degeneracy and references broader cultural concerns about the risks inherent in a market economy which relies too heavily on credit. It is hard to miss both the novel's heavy didacticism concerning the evils of gambling and its impulse to define innocent games of chance played by children against illicit games of hazard. Mr. Vincent, for example, is ejected from the novel in part because of his gambling addiction. ${ }^{121}$ As noted by critics, anti- gaming rhetoric is conventional in eighteenth-century domestic fiction. ${ }^{122}$ Here, Mrs. Stanhope recommends that women "learn" to play cards, not as an acceptable pastime, but as a means by which to make money and, by rendering themselves "independent," avoid the traps of marriage. Clearly she is a "bad" girl.

The gaming table also works metaphorically; the cards the women of Mrs. Stanhope's anecdote have not "learned" to play are, of course, the tropes of desirable femininity. In other words, although Mrs. Stanhope criticizes the girls' behavior, she intends for Belinda to learn by their mistakes and to practice both a more desirable version of femininity and a more economical method of courtship. Yet the notion that Belinda should learn to avoid "exposing herself" as have these "giddy" girls suggests that rather than being herself, Belinda, too, will put on a show—she will simply be more successful, i.e, more convincing.

Of course, readers would be suspicious of such advice. Certainly, women's dissimulative "art" is the subject of much eighteenth-century misogynist satire. ${ }^{123}$ In the courtship plot, however, the conventional emphasis on essence over artifice privileges an emerging moral economy within which internal qualities serve as the foundation for marriages based on mutual esteem rather than physical attraction. We might think, for 
example, of the famous scene within which suitors debate whether or not Burney's Evelina "paints." Similarly, we learn later of Lady Delacour's "cancerous" breast when she "wipe[s] the pain from her face" to reveal that, in contrast to what everyone else has seen, "no trace of youth or beauty remained on her deathlike countenance" (31). Edgeworth knows that her readers are sufficiently trained to reject out of hand Mrs. Stanhope's suggestion that Belinda employ such artifice. Belinda will demonstrate that rather than practiced at or planned, "the growth of affections must be spontaneous" (239). Love, like femininity, should come "naturally" and should not depend on games and ritual.

Mrs. Stanhope's linguistic dependence on metaphors bound up in the rhetoric of a market economy further betrays her "bad girl" behavior. Specifically, she warns Belinda to "speculate in time" so as not to "fail in her matrimonial expectations." In other words, she should recognize that courtship is not only a business venture, but often a shady investment, requiring craft and cunning. Armstrong has shown that conduct-book literature worked at "developing a language strictly for relations within the home" in order to establish a "private economy apart from the forms of rivalry and dependency that organized the world of men" (Desire, 75). But the learned skill which Mrs. Stanhope recommends is exactly what conduct-book literature eschewed; in essence, she rejects what Armstrong identifies as the "rigid distinctions between domestic duty and labor that was performed for money" (Desire, 79). Here, the otherwise public dangers of gaming and the inherent evils of a market economy have leaked into the private sphere, contaminating heterosexual love, courtship, and the sanctity of marriage. 
Hence, Mrs. Stanhope's recommendations are laced with maddening contradiction. As she peddles her advice, she warns Belinda "do not, by an ill judged economy, counteract my views" (9). Yet Belinda must counteract these views, for it is Mrs. Stanhope who practices an ill-judged materialist economy. While she warns her niece not to "expose" herself as have the young coquettes, she simultaneously sends her to the city precisely for exposure--to be seen and desired. In fact, Belinda has already been overexposed; Mrs. Stanhope, anxious to have another niece married upwards, has "hawked about everywhere" Belinda's wares. Says a cynical suitor, "You hear of nothing, wherever you went, but of Belinda Portman, and her accomplishments" (25). Of course, these measures of value prove illusory. As Katherine Sobba Green has argued, Edgeworth joins the ranks of many other women writers of this time in attacking the inadequacies of the marketplace blazon as a signifier of women's value. ${ }^{124} \mathrm{Mrs}$. Stanhope's "false" advertisements of her other nieces have resulted in miserable marriages and the "hawking" of Belinda nearly thwarts her final engagement to Hervey, who suspects, based on precedent, that if he courts her he might be swindled.

In essence, Belinda is reduced to a commodity, and further degraded because she is "hawked about" by a third party. Says the same cynical gentleman, "'Belinda Portman, and her accomplishments...were as well advertised, as Packwood's razor strops"” (25). Similarly, in Edgeworth's Ennui (1809) the main character questions the value of Packwood's razors because their advertisements are written not by the Packwoods themselves, but by a hired poet. ${ }^{125}$ Edgeworth implies that the corruptions inherent in a capitalist market create an atmosphere of distrust, suspicion, and inauthenticity, and that this mentality, when applied to marriage, proves devastating. 
Another gentleman corroborates the suspicions of the first, "Mrs. Stanhope overdid the business, I think... Girls brought to the hammer this way don't go off well"' (25). Indeed, Hervey, although attracted to Belinda, refuses to court her for fear of being cuckolded, and engages himself instead to Virginia St. Pierre; Belinda, angry at being spoken of as a commodity, and angrier yet at being misjudged, turns her attentions away from Hervey to Vincent. Both nearly wind up with the wrong person as a result of both Mrs. Stanhope's interference and the ideology of courtship as a market.

Mrs. Stanhope is not the only woman to treat Belinda like a commodity or to proffer bad advice. After her husband refuses to lend her the money for the coach and horses, Lady Delacour manipulates Clarence Hervey into financing the project. Hervey, wishing to make peace with Belinda for the "razor-strop talk" which she overheard, asks Lady Delacour if she will make peace between him and Belinda. Lady Delacour duplicitously suggests that Belinda will look more favorably on him if he offers to buy for her some horses she has admired. "May I thus seal my treaty of peace?" asks Hervey, gallantly fronting the money for the purchase (79). Belinda, of course, unimpressed by material things, continues to treat Hervey coolly, and he, in turn, accosts Lady Delacour, "I have not been able to obtain one smile from miss Portman since I have been promised peace" (81). Here, the not yet reformed "hero" of the story also objectifies Belinda's body, suggesting that Lady Delacour must either pay him the debt in money or in a display of Belinda's “gratitude.” In essence, Hervey turns Lady Delacour into Belinda’s madam, pressuring the older wo man to supply the goods or refund him his money.

But Belinda, as Lady Delacour discovers, does not operate within the same economy; indeed, they represent two different forms of "sense" or logic. Lady 
Delacour's ignorance concerning Belinda's value system becomes abundantly clear when, to make good on her side of the bargain, she attempts to talk Belinda into reconciling with Hervey. She tells Belinda she has borrowed the money from Hervey on condition that Lord Delacour had promised to pay for them, but has since changed his mind and refused to give her the money. She adds, slyly, "I forgot to tell you, that I took your name—not in vain indeed—in this business....my dear, why do you look as if I had stabbed you to the heart—after all, I only drew on your pretty mouth for a few smiles" (82). She teases Belinda further, telling her that with just one smile she will be "out of debt and danger" (83). Lady Delacour openly admits to her transformation of Belinda into a body of credit, one which, although not her own, she can draw on to repay material debts. Her discourse is contaminated by the language of a risky credit economy, one which can turn anything, or anybody, into a potential resource. "I took your name," she says, on one hand referencing her unauthorized use of Belinda's name (and misrepresentation of her desires) to seal the deal, but the more morbid implication is obvious; in bartering Belinda's body she has attempted to erase her subjectivity. Moreover, she uses her position as Belinda's friend and mentor to manipulate the younger woman's good nature. She is a bad friend, and a bad woman-a fact which she self-reflexively recognizes when she notes Belinda's pained expression.

Yet Belinda, ever "economic of her smiles," circumvents her own commodification, keeping her smiles to herself and paying Lady Delacour's debt out of her own inheritance (84). She tells a baffled Lady Delacour who privileges one's bank account over one's integrity, "It is better for me to throw away fifty guineas, than to hazard the happiness of my life" (84). By repaying Hervey with money rather than in 
smiles, Belinda maintains control of the terms and conditions of the transaction, wisely noting, "Your ladyship knows that if I say $a$ to Mr Hervey, I must say $b "$ (84). While Lady Delacour would rather take the chance that Hervey will be satisfied with no more than a smile, Belinda refuses to gamble. Voluntarily giving up a set amount is safer than the game of hazard entailed in offering one's body as a credit, wherein values and value systems are much less clearly delineated and can easily give way to greater obligations. Belinda recognizes that to accept her status as a commodity, or her body as credit in a marriage investment, is to forfeit what she believes to be her natural and otherwise stable value as a person. Later, Hervey notes approvingly, "Though her aunt has advertised her...she seems to have too much dignity to advertise herself' (73). Edgeworth suggests that men, although willing to submit to the rules of the marriage market and trade in women, actually prefer women who possess the moral integrity to refuse their own commodification.

The "bad" girls of the novel, of course, continue to try to cash in on their own and other women's bodies. Harriet Freke, for example, plans to profit by what she sees as the inherent rivalry between women. Having heard of the rift between Belinda and Lady Delacour, the masculinized Freke offers to "set the distressed damsel free" and "carry [her] off in triumph" (225). Hoping to ingratiate herself with Belinda, she attempts flattery: "I've pledged myself to produce my beauty [Belinda] at the next ball, and to pit her against their belle for any money" (225). Having "bet twenty guineas on [her] head," Freke is astonished when Belinda rejects her offer of an alliance, and cries out, "And will you make me lose my bet?...O, at all events you must come to the ball! I'm down for it!" (226). Like Lady Delacour earlier, Freke expects to use Belinda's body and beauty to get 
her out of “debt and danger." Similarly, she can't make sense of Belinda's resistance. Belinda once again makes it clear that she will act no such part, telling her, "It is not in my power, madam... to comply with your request" (232). Of course it is not in Belinda's power; as Irigaray has articulated, neither the control nor the exchange of women's bodies is in women's power within a patriarchal economy, however they might try to manipulate the market. Thus, as Belinda sees it, the only way out of her own commodification is to resist the body entirely, to disavow of all bodily sensation/desire.

Repeatedly throughout the book, Belinda resists the logic of the market economy, insisting on her independence from its rules. The men in the book, like Lord Delacour, come to desire her not as a body but as a female subject whose value cannot be translated into market logic. As a conduct-book heroine, she recognizes that "[i]t is a woman's participation in public spectacle that injures her, for as an object of display, she always loses value as a subject" (Armstrong, Desire 77). Of course, the "bad" girls of the novel do not recognize Belinda's logic as good economy, preferring instead the credit-based rules of the male-driven market economy. When Belinda disproves their logic as "not the right kind of sense," she effectively replaces marketplace logic with what Armstrong terms, "an economy that is not money"-in other words, Belinda's choices represent the "subordination of money to a higher standard of value..." (83). In refusing to be commodified, she suggests that not only love, but women, too, are "ineffable, irreducible, to the materiality either of a market economy or of patriarchal exchange" (Green 75). Men must learn to listen to her, for her value lies in her ability to cure the $m$ of the depravity they have been contaminated with by the public sphere. Thus, in resisting women's commodification and the logic of the marriage market, and in suggesting that 
men naturally do desire women's internal value, Edgeworth is recommending a shift that affects not only the private but also the public sphere. Belinda's behavior reforms Hervey, a public actor, who in turn will translate what he has learned at home into his relationships abroad. In other words, the adoption of Belinda's sense allegorizes the recommended global transition from a money-based to a moral economy.

The novel also allegorizes a shift in the literary tradition as described by Armstrong. Belinda literally is a body of words, the control of which signifies a switch in penmanship from male to female hands. Belinda's job as exempla is to reject what she has learned from fashionable women: "To her aunt Stanhope she had hitherto paid unlimited, habitual, blind obedience; but she was more undesigning, and more free from affectation and coquetry, than could have been expected after the course of documenting, which she had gone through" (10). Belinda has not been "documented," try as her aunt might. In turn, Edgeworth takes advantage of the blank page that is Belinda, transforming her into a performative text of what should be desirable femininity. The novel, whose title bears the name of its heroine, is in fact a historicizing act of ideological embodiment, the corporealization of a set of moral values which will come to be linked with the middle-class. Essentially, Edgeworth erases a long literary tradition intent on documenting women within the sexual contract and establishes in its stead a literary tradition which not only grants subjectivity to women, but also enables its female authors to practice revisionist strategies on conventional narratives. 


\section{Revising the Romance Plot, Resisting Rivalry}

Edgeworth's criticism of the market economy and its corrupting effects on the private sphere does not, in itself, render her novel feminist or even proto-feminist.

Belinda, both the character and novel, work to negotiate tensions between what Elizabeth Kowaleski-Wallace terms "old-style patriarchy," based on force and bound up in corrupt aristocratic interests, and "new style patriarchy," operating through filial obligation and servicing an emerging middle-class mentality. Yet even as the new domestic ideal works to maintain male authority and privilege and to sustain a patriarchal, capitalist economy, the novel offers up a radically feminist alternative. I suggest that whereas most conventional domestic fictions privilege the sanctity of domestic conjugality, the emphasis of Belinda is on preserving female homosocial intimacy. In other words, much like Sarah Scott's Millenium Hall and Frances Burney's Cecilia, the drive of the narrative is bent on emphasizing the corrupting influences of patriarchal ideology on women's relationships with each other, challenging the myth that women are inherently rivals, and suggesting the intensity of women's desire for female community.

It is important to acknowledge ways in which Edgeworth resists the good girl/bad girl dyad she has herself relied on, suggesting that "bad" girls are made, rather than born. The moral flaws of women like Mrs. Stanhope are clearly not inherent in femininity. Encouraging her readers to reject Mrs. Stanhope's recommendation for "selfimprovement," Edgeworth implicitly criticizes the trappings of contemporary female education and the double-standard of conduct book rules which she also satirized in her Essay on the Noble Science of Self-Justification (1795). In that essay, as in her fiction, she echoes Mary Wollstonecraft in Vindication of the Rights of Woman (1792), blaming 
sexist ideologues like Rousseau and Halifax for schooling young girls in a "false system of female manners" (144). It is important in this context to identify Edgeworth's alignment with Wollstonecraft because critics have often read Harriet Freke as an emblematic mockery of Wollstonecraft. ${ }^{126}$ In fact, the rakish behavior of women like Freke, Stanhope, and Lady Delacour seems exemplary of the faults of the flawed system of female education which Wollstonecraft attacks. Certainly characters like Mrs. Stanhope and Lady Delacour are themselves the dupes and products of conduct-book advice by men like Rousseau, ${ }^{127}$ which although encouraging propriety, instead often reap "a mixture of madness and folly" (Wollstonecraft 154). ${ }^{128}$ In other words, it is not the women themselves, but the masculinist "sense" into which they have bought which Edgeworth satirizes. As Audrey Bilger has argued, eighteenth-century women writers consistently relied on negative exempla (often satirical portraits of other women) to "satiriz[e] the standards of female conduct" (86) and to "draw attention to the nonsense of sexist values" (97). In fact, Lady Delacour acknowledges the error typically made by society that "a woman who is known to play the fool, is always suspected of playing the devil" (35). Essentially, she admits her actions may have been foolish, but insists she is not, herself, evil. Arguably, Edgeworth suggests that bad girls are only "bad" girls because they have been poorly trained by a "bad" society driven by male desire. One might say they have all, like Harriet Freke, been caught in, or caught up in, man-traps! ${ }^{129}$

Furthermore, I suggest that Edgeworth's revision of the good girl/bad girl dyad also entails a revision of conventional romances which, she suggests, more subversively than conduct books instill in women "a mixture of madness and folly." Early on, Lady Anne, the novel's other "good" girl predicts that "the period of [Lady Delacour's] 
enchantment will soon be at an end, and she will return to her natural character" (105). This "enchantment" no doubt refers to Lady Delacour's internalization of a materialist values. Her "natural" character is that which belongs to the moral economy both Belinda and Lady Anne champion. Lady Delacour's acceptance of her own commodified status "enchants" her so that she doesn't recognize her true internal worth. But Lady Anne's use of the word "enchantment" also refers to Lady Delacour's consistent misreadings of reality because she insists on looking through the lens of romance; Lady Delacour is, to some extent, an enchanted female Quixote.

Lady Delacour, at times, becomes aware of her miseducation in romance. She wisely reminds Belinda (and Edgeworth's readers), "nothing is more unlike a novel than real life" (36). Although a "bad" woman, her negative experiences have given her the perspective to view keenly her society and its flaws. Most importantly, she knows what has caused her fall. Although transparent when she scapegoats other women like Mrs. Luttridge, she is most convincing when she recognizes the damaging impact of romances on her relationships with other women. In fact, the romances have negatively affected all the bad women of the novel—clearly satirized in Freke's knight errantry, but also treated seriously in depictions of the other women's value systems. In both Letters for Literary Ladies and Practical Education Edgeworth had criticized romances and recommended more sensible reading for women. ${ }^{130}$ I suggest that Edgeworth recognizes the dangerous mythology of female rivalry promulgated by romantic conventions. While not an advocate of censorship, she exploits these conventions, exposing the trope of female rivalry as overdetermined and banal, and those "informed" by such logic as not only gullible but irresponsible readers. Unlike Richardson who, as I have argued, suggests 
these flaws are inherent in femininity, Edgeworth implies that they are bad readers because they live in a society within which women's "education" occurs mostly at the hands of other poorly educated women, who instruct them only in the art of sexual desirability so they can marry upwards. ${ }^{131}$

Lady Delacour's overactive imagination and faulty reading skills are apparent from the start. Early on, Belinda writes to her aunt of her concerns about Lady Delacour's coquettish behavior. She later feels guilty for having betrayed Lady Delacour's confidence and is in the midst of writing a letter to her aunt requesting that she burn the previous letters when Lady Delacour comes on her. Startled and ashamed, Belinda tries to hide the letters and Lady Delacour misreads the cause of her distress: “[T]ears in the eyes! Blushes in the cheeks! Tremors in the joints! And letters shuffling away! But you novice of novices, how awkwardly shuffled! A niece of Mrs. Stanhope's and so unpractised a shuffler! And it is credible she should tremble in this ridiculous way about a love-letter or two?" (17). Lady Delacour fancies herself able to identify romantic intrigue; after all, Belinda "evidences" all the physical signs of a woman caught in the act of writing an illicit love letter. Provoked by Belinda's reluctance to share the contents of her letters and by her insistence that they are not love letters, Lady Delacour snatches them from her, crying: "No love-letters! Then it must be treason!" Seeing the na me "Delacour" written on the letters, she assumes the reference is to her husband. When Belinda begs her not to read them, Lady Delacour reasons, “"Why, this is like the duchess de Brinvilliers, who wrote on her paper of poisons, 'Whoever finds this, I entreat, I conjure them, in the name of more saints than I can remember, not to open the paper any farther'” (17). To support her faulty logic, Lady Delacour turns to other 
romances. But her situation is no romance, and after reading the letter, she learns the error of her ways - at least temporarily.

Later, Belinda's insistence that Lady Delacour reveal her condition to her husband re-awakens her suspicions. A "passion of jealousy" overwhelms her, and " $[\mathrm{t}]$ he moment [her] mind turned to suspicion, her ingenuity rapidly supplied her with circumstances and arguments to confirm and justify her doubts" (181). Never mind that Belinda is oblivious to both Lord Delacour's “charms" and Lady Delacour's suspicion because, ironically, she is "not sufficiently aware that jealousy can exist without love" (181). Accustomed to the romance plot which insists on scripting females as rivals, Lady Delacour fills in the blanks accordingly and can only read her ward as her rival. Enacting the part of a duped woman who has finally seen the light, she patches together the pieces of a conventional plot to arrive at the all too familiar story of female competition and intrigue.

Among the misconstrued evidence is the book-marked page of a moral tale read by Belinda. She grabs it from the table, exclaiming, "Ah ha!...She has been reading this; studying it. Yes, and she has studied it to some purpose..." (181). The tale, meant for Lady Delacour's edification, is about a woman able to govern a resistant husband through her own moral behavior. Ironically, the tale's female exemplar is exactly the sort of woman Belinda is and which she has suggested Lady Delacour become. But because romances have corrupted her reading skills, she mistakes the moral of the tale and Belinda's reading of it as evidence of a plan to win, marry, and then govern Lord Delacour. She assumes Belinda has been reading up, taking notes, cramming, if you will, for the ultimate test—beguiling her friend's husband. Further, Lady Delacour immediately assumes that her own friend, Mrs. Stanhope, has been instructing her niece 
in how to cuckold her. All of Belinda's natural, otherwise admirable behaviorskindness towards Lady Delacour's daughter, Helena, her reserve towards men in general, and her refusal of the rakish Baddeley's proposa—-are re-read and translated within the context of scandalous romance.

Clearly, Edgeworth suggests that while damaging to marriages, the trope of female rivalry circulated by romances wreaks much more havoc on female friendships. This privileging of female friendship over heterosexual relationships is a significant revision of the romance plot and works alongside her negotiation of another significant convention— the gallant hero, as epitomized by Richardson's Sir Charles Grandison. The male characters are either disappointing bores, dupes, and/or drunks. Colonel Lawless, over whom Mrs. Luttridge and Lady Delacour duel, never appears in person in the text and Lady Delacour admits he is "as empty a coxcomb as you would wish to see" (38). Indeed, he loses a duel to the rarely sober Lord Delacour, who with his creaking shoes is certainly no chivalric knight. In fact, when Belinda first encounters his servants carrying him up the stairs, Lady Delacour dismisses the spectacle as "Only the body of my lord Delacour"- a significant commentary on his lack of substance (11). Mr. Vincent, whom Belinda nearly marries, is a profligate gambler, a "man of feeling" ultimately too silly to be taken seriously; although engaged to him when she discovers his weaknesses, Belinda feels no great loss at his departure. Even Clarence Hervey, the novel's "hero" is an egomaniac of "chameleon character" (14). In squirreling away the innocent Virginia in what is clearly another one of Edgeworth's attacks on romances, ${ }^{132}$ he resembles less a Grandison than a Lovelace. All of the men lack the substance required to make them 
credible as objects inspiring the women's fierce rivalries, evidencing Edgeworth's exploitation of the banality of romance plots.

The most explicit instance of men's symbolic absence is a suspect gap in a letter alluding to Clarence Hervey. Having written to her Aunt with concerns about Lady Delacour's flirtations with Hervey, Belinda has left his name blank in case the letter should fall into the wrong hands which, of course, it does. Reading into the gap's ambiguity, Lady Delacour says coolly, “'does Mrs. Stanhope think no one can make out an innuendo in a libel, or fill up a blank, but an attorney general?"” (17). Belinda, Mrs. Stanhope and Lady Delacour are all versed in the language of the romantic love plot, all trained readers/interpreters of their antagonistic positions in its narrative. However, Edgeworth leaves blank the position normatively occupied by the male, indicating the gap they create in the narrative of female homosociality. As gaps/blanks, men and the heterosexual matrix they symbolize are, in essence, empty narrative devices-regulatory functions designed to service a hegemonic ideal. If Lady Delacour were not flirting with Hervey she would be flirting with someone else. Harriet Freke insightfully acknowledges this fact when she later accuses Lady Delacour of marital infidelity: "As to who the man might be, that's no matter. One Lothario is as good as another" (311). Even the "good" men, however, are interchangeable. Captain Sunderland effortlessly replaces Hervey in Virginia's affections, and Belinda switches her desire from Hervey to Vincent and back to Hervey.

As the novel draws to its conventional close, Edgeworth makes explicit her criticism of romantic love's interference in female friendships. Prior to positioning Hervey and Belinda in a romantic pose, she teases them (as Edgeworth does the reader) 
by suggesting that she draw out the end of the "novel" rather than provide immediate closure. After all, Lady Delacour explains dryly, "A declaration of love, you know, is only the beginning of things; there may be blushes, and sighs, and doubts, and fears, and misunderstandings, and jealousies without end or common sense, to fill up the necessary space, and to gain the necessary time..." (477). Lady Delacour's reference to misunderstandings and jealousies recalls the narrative of betrayal she herself concocted to make sense of her relationship with Belinda. But she also suggests that "any declaration of love," any narrative of sexual desire, relies on female rivalries, which, if examined, defy reason.

Nevertheless, Belinda does end in the usual way, with Belinda making preparations for marriage and Lady Delacour safely domesticated. Yet Edgeworth's most trenchant criticism of the prescriptions of the romantic plot occurs at the novel's close, in Lady Delacour's staging of the domestic tableau. Says Lady Delacour, Now I think of it, let me place you all in proper attitudes for stage effect. What signifies being happy, unless we appear so?...Clarence, you have a right to Belinda's hand, and may kiss it too. Nay, miss Portman, it is the rule of the stage. Now, where's my lord Delacour? He should be embracing me, to show that we are reconciled...There! Quite pretty and natural! (478)

No doubt the performativity of this scene calls into question the novel's utopic close. What appears "quite pretty and natural" also calls to mind the depiction of the idealized Percival home, suggesting perhaps the orchestration of that scene as well. The "rule of 
the stage" presumably continues to guide even the reformed Lady Delacour's hand, just as it does Edgeworth's pen, so that while she remains loyal to the necessary prescriptions of the romance tableau, she also signals the over-determined conditions of authorship.

\section{Female Intimacy and the Conditions of Sorority}

\section{Theorizing Women's Betrayal of Other Women}

Edgeworth's emphasis throughout her criticism of conventional romance plots is on how the trope of female rivalry devastates women's friendships. Not only does it serve to alienate women from each other, but the mythical rivalry that exists between all women, a condition of the materialist economy Edgeworth explicitly criticizes, renders tenuous all alliances forged between women.

Lady Delacour befriends Freke only because she assumes that unless allied with her, Harriet will become a dangerous rival: "As a rival, she would on certain ground have beaten me hollow; it was therefore good policy to make her my friend. We joined forces, and nothing could stand against us" (43). The either/or logic on which Lady Delacour bases her decision speaks to the impossible bind placed on women in terms of their relationships with each other. It also suggests Lady Delacour's acknowledgement of her embattled position in society; she feels at war with the world, desperate for allies in a society where she has few rights and freedoms. Lady Delacour explains to Belinda, "You see I had nothing at home, either in the shape of husband or children, to engage my affections. I believe it was this 'aching void' in my heart which made me, after looking abroad some time for a bosom friend, take such a prodigious fancy to Mrs. Freke" (443). One might read in this example Edgeworth's trenchant conservatism. Lady Delacour's 
failure to find happiness at home speaks to her moral waywardness and her ill-judged friendship with Harriet represents exactly the sort of dangerous power women, if joined, might possess. Nevertheless, we can simultaneously read Lady Delacour's explanation of their friendship as evidence of Edgeworth's feminist resistance to patriarchal logic. The "aching void" isn't naturally filled by husband and children; something else pulls at Lady Delacour, and her desperate friendship with Harriet Freke testifies to the intense desire for female friends, even in the face of social approbation.

Yet these friendships are always conditional, framed within the context of a preexisting rivalry and the knowledge that one can easily swap alliances. A significant characteristic of the friendships and rivalries in Belinda is that they are always in a state of transition, operating through the exclusion of a third party. Lady Delacour explains to Belinda, "My hatred to Mrs. Luttridge, my dear, is the remote cause of my love for youfor it was the cause of my intimacy with your aunt Stanhope. Mrs. Stanhope is really a clever woman, she knows how to turn the hatred of all her friends and acquaintances to her own advantage" (62). Lady Delacour and Mrs. Stanhope have in common a hatred of Mrs. Luttridge; when Mrs. Stanhope "ministers" to Lady Delacour's hatred (63), the two become fast friends. Similarly, Freke assumes, based on precedent, that Belinda will ally with her and Mrs. Luttridge because "[n]othing unites folks so quickly, and so solidly, as hatred of some common foe" (223). These relationships, based on a shared hatred of another woman, testify to the oppressive and frustrating conditions of female friendship within a masculinist economy. Alliances between women depend on the necessary exclusion of other women. 
In this respect, these fictional relationships mirror the ways in which women in reality tend to interact with each other and speak to one of the ways by which patriarchal privilege is maintained. Studies have shown that girls and women generally "create a series of tribal-like dyads or small cliques only by excluding a series of enemies, who are, in some way, either different or merely vulnerable" (Chesler 117). Because females are socialized to be dependent rather than independent, belonging is more important to them than it is to males. At stake in any relationship between women is the ever-present threat of exclusion, so ominous that it defines female friendships. Within this patriarchal model, women are supposed to think of such intimacies as inherently temporary-and while having invested so much more in belonging than men, learn to invest so much less in friendships with other women. As Irigaray has noted, women's relationships are further complicated by a market economy. Raised to view each other as commodities, the process by which women exchange friends for rivals must seem to come "naturally." How easy it is to give up another female friend when her value is always, already predicated on the floating value of another girl's desirability—and when the goal of exchange is always male desire/approval. How easy it is to lose a friend if the alternative is to be excluded oneself. Thus, Harriet Freke's heartless betrayal of Lady Delacour, Marriottt's immediate envy of Belinda, and Lady Delacour's ready belief that, alternately, Marriottt, and then Belinda and Mrs. Stanhope are plotting against her.

In this respect, Edgeworth complicates Mr. Percival's opinion that "Women who have lowered themselves in the public opinion cannot rest without attempting to bring others to their own level" (253). Edgeworth suggests that the causes underlying women's mistreatment of each other are much more complicated than this overly simplistic 
explanation allows. By Percival's logic, Freke, a caricature never granted the psychological depth given to Lady Delacour, might seem to fit easily into her half of the good girl/bad girl dyad; yet it is Edgeworth's investment in complicating Lady

Delacour's behavior that implies the need to investigate the terms and conditions of all the women's relationships with each other. Arguably, Freke, Marriott, and even Mrs. Stanhope assert despotic power over other women because they possess no power elsewhere and because they have internalized a masculinist logic that rationalizes the mistreatment and objectification of women.

\section{Theorizing Female Homosocial Desire}

The trope of female rivalry always shadows female alliances. Moreover, the uncontested internalization of these tropes leaves women unable to account fully for their rivalries with other women. Indeed, women in the novel have a difficult time making sense of their rivalrous relationships with other women. Lady Delacour confirms this when she explains that the irreparable breach between women is that which "never comes to words. Your true silent hatred is that which lasts for ever" (63). In fact, the unexamined silence maintains the trope of female rivalry. Women accept the "necessary jealousies" prescribed to them by the romance plot, even when inexplicable. Lady Delacour says of her "seven years war," "I certainly hate Mrs. Luttridge the most---I cannot count the number of extravagant things I have to done to eclipse her. We have had rival routs, rival concerts, rival galas, rival theatres--She has cost me more than she's worth" (62). Yet neither within the materialist nor the moral economy does the rivalry between the two women make sense. I suggest that by calling attention to the absence which constitutes 
the source of their rivalries, while simultaneously emphasizing the pull women feel toward each other, Edgeworth enables her readers to recognize the "nature" of women's desire, one which exists outside and prior not only to the material economy, but to the heterosexual matrix.

The first nonsensical aspect of their rivalries is that both women recognize that the material and moral costs outweigh what they are fighting over. Irigaray's analysis of the commodification of women within a market economy is partially useful for theorizing their relationship. She says of the woman who performs her societally assigned role, "The fact remains that this masquerade requires an effort on her part for which she is not compensated" (84). Playing by men's rules, women like Lady Delacour cannot be compensated; their prescribed rivalries cost them more than they are worth-yet they continue to desire interaction with each other-perhaps in the hopes of some form of compensation.

Secondly, we are never quite sure why their rivalry began in the first place; in other words, although the initial rivalry gets displaced onto the rival galas, etc, no adequate explanation is given of the origin of their mutual hatred. Lady Delacour provides us with only a brief background: that in an effort to make Lord Delacour jealous, Lady Delacour had coquetted with Colonel Lawless, who the "odious" Mrs. Luttridge had smiled on. It seems that Lady Delacour chooses Colonel Lawless because other women admire him (45). Later, after Lord Delacour duels with Lawless, Mrs. Luttridge, in retaliation becomes his "partisan" (53). Yet as I have already discussed, neither man is desirable in himself. 
I want to suggest that the significance of the men's interchangeability, their symbolic emptiness in the text, can be complicated further by imagining a genderspecific revision of Rene Girard's theories of triangulated desire. Says Girard, "When the 'nature' of the object inspiring the passion is not sufficient to account for the desire, one must turn to the impassioned subject" (2). Certainly the objects inspiring the passion—Lord Delacour and Colonel Lawless—are not sufficient to account for the "seven years war" between the two women. What, then, can we say of the impassioned subjects? "A vaniteux," says Girard, "will desire any object so long as he is convinced that it is already desired by another person whom he admires" (7). By this logic, and if we are to substitute "he" for "she," Lady Delacour desires Lawless because Mrs. Luttridge first desires him, and Mrs. Luttridge becomes a "partisan" of Lord Delacour because she, in turn, "admires" Lady Delacour.

However, I posit that the women of the novel are not simply vaniteuses, and that Edgeworth, like Frances Burney, articulates a subversive theory of female homosocial desire operating through a female-identified erotic triangle. If we turn to Sedgwick's revision of Girard to account for homoerotic desire, we can understand the connection between the rivals as more intense than "admiration." Sedgwick relies on Girard's suggestion that "in any erotic triangle, the bond that links the two rivals is as intense and potent as the bond that links either of the rivals to the beloved" (21). She notes, for example, in Shakespeare's Sonnets that "we are in the presence of male heterosexual desire, in the form of a desire to consolidate partnership with authoritative males in and through the bodies of women" (38). In other words, compulsory heterosexual desire and 
the rivalries over women which can define it actually function, on one level, to secure male homosocial bonds.

In turn, Diana Wallace, revising Sedgwick, theorizes a female-identified erotic triangle. She asserts that "Within a patriarchal society, utterances between women are frequently fractured by the "shadow' of a man" (71). In other words, men conventionally come between women, jealousy initiating the "silence which never comes to words" which Lady Delacour describes. In response, a revisionist strategy by women writers of domestic fiction is to invert the normative traffic in women: "women, positioned as commodities within a 'male hom(m)osexual economy' can also operate within a female economy,' within which men can be commodified and 'exchanged'” (Wallace 59). In this way, women positioned as rivals for the desire of a male object use that man to mediate the desire that they actually feel for each other, but are prohibited from acting on. Nor does this desire necessarily need to be homosexual; as Sedgwick makes clear, the homoerotic exchange of a desired object can function as one way within which two people of the same gender secure empowering ties with each other-ties just as or more intense than those for the object of desire.

Hence, I posit that the men in Belinda function in part to solidify female community. In other words, the women of Belinda really desire unmediated female friendship, but because of the vexed conditions of women's relationships with each other, as well as the social prohibitions against female homosocial intimacy, they must channel their desires through male bodies. Essentially, Edgeworth exploits the 'absence' that men represent in conventional romances, first revealing the gap they create in women's intimacies with each other, and then turning that gap back on itself so that women 
channel their desires for each other through the empty bodies of male characters. This is especially clear in the exchange of Mr. Vincent between the women of the text; as easily transformed into a commodity as the products of the West Indies Island from which he comes, he is swapped back and forth in a power-play between Mrs. Luttridge, Harriet Freke, Lady Delacour, and to some extent, even Lady Anne. ${ }^{133}$ Without the men over whom to fight, the women have no opportunities either to exert their own power, nor to engage in relationships with each other.

There are, however, moments in the text when the women's passion for each other unleashes itself and these moments corroborate my claims about a primary female homosocial desire. When Lady Delacour fears Belinda has betrayed her, it is neither Lord Delacour nor, ultimately, his coronet which she mourns. Rather, she mourns the loss of her intimacy with Belinda, crying out, "Belinda! How entirely have I loved! Trusted! Admired! Adored! Respected! Revered you!" Later, she again cries out, tears smearing the paint from her cheeks, "Oh Belinda! You! Who I have so loved! So trusted!" (205). It is, in fact, Lady Delacour's belief that Belinda has become her rival that enables her to express finally these feelings. To this point she has maintained the façade she carries with her abroad; Belinda's emergence as a rival means that Lady Delacour can safely express those private feelings she has harbored.

Further, Lady Delacour evinces no equivalent measure of passion for Lord Delacour, even after her reformation. In fact, no believable heterosexual passion exists anywhere in the novel. The ideal couple, the Percivals are as cool as Belinda since uncontrolled passion threatens the order of an enlightened domestic utopia. Thus, the only demonstrated passion in the text occurs between women, specifically in Lady 
Delacour's emotional outbursts when she fears she has lost her female friends. Indeed, Belinda is not the only friend she mourns. When she loses Harriet to Mrs. Luttridge's camp, Lady Delacour falls sobbing into Belinda's lap after crying out, “O Harriet! Harriet! You desert me! Any thing else I could have borne...!" (32). Moreover, the intens ity of the "hatred" between Mrs. Luttridge and Lady Delacour culminates in a duel, the guns they wield arguably phallic substitutes and it is of no small significance that Mrs. Luttridge and her "friend" both arrive dressed in men's clothes (56). The duel, although resulting in Lady Delacour's “cancerous” breast also unites Lady Delacour with a new good friend, Miss Honour O'Grady, so that female rivalry does, ironically, solidify female community.

In fact, in the same way that the women can exchange men between them to solidify alliances, so too can they subvert the triangular clichés of female friendships. Mrs. Luttridge and Lady Delacour fight for Freke's loyalty, but this rivalry for Freke can also be read as a displacement of their desire for each other. Similarly, Freke and Lady Delacour battle each other for Belinda's love, potentially evidence of their intense feelings for each other. And if Mrs. Stanhope and Lady Delacour unite because they both hate Mrs. Luttridge, then perhaps, to some extent, they both desire her in some form. This is not to say that Edgeworth imagines a female utopia within which all the women actually love each other; as I will argue below, she recognizes certain problems inherent in idealized sorority. However, I do want to posit that a theorization of erotic triangles potentially makes sense of otherwise inexplicably intense rivalries. Moreover, and perhaps more importantly, it provides us the conceptual capacity for opening up the good 
girl/bad girl dyad to recognize Edgeworth's rendering of female rivalry as multidimensional, intensely complicated, and, hence, more realistic.

\section{Sorophobia v. Sorority}

I have been arguing that the narrative's drive, by focusing on female rivalry, is to emphasize the devastating effect of women's betrayal of other women. Yet where she has the opportunity to resolve one of these rivalries, Edgeworth remains silent. As Lady Delacour ponders how to close her "novel," she suggests to Mrs. Delacour that she conclude "with a characteristic letter of congratulation from Mrs Stanhope to her dearest niece, Belinda, acknowledging that she was wrong to quarrel with her... and giving her infinite credit for that admirable management of Clarence Hervey, which she hopes will continue through life" (478). Although Mrs. Delacour does not object to reconciling, Lady Delacour closes instead with a riddle that makes no mention of Belinda and Stanhope. One might argue that the reunion of Lady Delacour and Belinda works to displace the tension between the latter and her aunt, yet I suggest that the last minute reference to Stanhope leaves both the bad girl/good girl dyad and the narrative of female rivalry uneasily in place.

In its maintenance of these rivalries, Edgeworth's novel might seem, at first glance, to fit easily into stereotypical portrayals of dangerous female friendships which too easily cause the moral downfall of otherwise "good" women. The novel's "pattern" man, Mr. Percival, suggests as much with his disparaging comment about bad women's desire to drag other women into their depravity. As critics have argued, fiction in the mid to late eighteenth century evidences a powerful desire to contain female friendship and is 
rife with satiric attacks against fictional female communities. ${ }^{134}$ No doubt, these depictions stem from fears concerning emerging feminist arguments borne out of Enlightenment discourse. Belinda is also guilty of depicting a dangerous female enclave although, as I will argue, even this depiction is fraught with ideological gaps.

Harrowgate is the home of Mrs. Luttridge and a place of dangerous, unmediated female exchanges. It is the site where women control the gaming table and cheat naïve visitors out of their money. It is the place where men, like Mr. Vincent, get ruined, and out of which "both master and man" have been driven (223). ${ }^{135}$ Its name suggests a dangerous, harrowing, even hellish place — a direct contrast to the domestic ideal at Oakley Park. ${ }^{136}$ Moreover, it connotes dangerous fecundity. According to the OED, a harrow is a heavy tool with iron teeth, a trench-making implement designed to rake ground to make it more fertile. We might imagine the female community of Harrowgate as homo-socially reproducing, making more fruitful their subversive desires, and crouching in their trenches to fortify an attack against the enemy. The site is also a gate, locking out male authority as well as an illicit gateway out of the repressive strictures of feminine propriety—-there women dress and behave like men and launch rhetorical attacks against virtue and female decorum. In a conservative reading of the text, Harrowgate allegorizes the collapse of separate spheres, the thorough contamination of the home by the forces of the corrupt and corrupting market.

Nevertheless, I suggest that we can also read Harrowgate as a feminist call for uninterrupted female friendship. Early in the novel, Lady Delacour's aunt, Mrs. Margaret, responds sarcastically to Lady Anne's prediction that Lady Delacour will become a domestic woman, "some people believe in the millennium—but I confess I am 
not one of them..." (105). Edgeworth calls into question Lady Delacour's reformation by exploiting the banal tropes of romance; she seems, like Mrs. Margaret, to be skeptical of domestic utopias capable of reclaiming wayward women. I suggest that for Edgeworth, neither millennium nor Scott's utopic Millenium Hall exists. Harrowgate is, in fact, the seeming antithesis of Scott's utopic vision. I posit that for Edgeworth Millenium Hall is a fantasy; in fact, Harrowgate exists because Scott's utopia does not and cannot exist in a male world.

Like Millenium Hall, women have been driven into Harrowgate by the misogynist demands of the marriage market. To this extent, Harrowgate can be read as a refuge, albeit an illicit one. Edgeworth makes clear throughout that, outside the world of Harrowgate, romantic love comes between women. Harrowgate protects and maintains female friendships, however dissolute. If "romantic love is the snake in the garden of [female] friendship" as Straub suggests (131), then Harrowgate is safe precisely because "both master and man" have been driven out. It is the site where Edgeworth's own iron (and ironic) teeth rake out a place for unmediated female exchanges. Arguably, Edgeworth recalls Delarivier Manley's satiric depiction of the all-female Cabal in The New Atalantis, written nearly a century earlier. Edgeworth views askance the illicit behavior of these rebellious women. Yet like Manley, Edgeworth treats these same women sympathetically, empathizing with their need to "reserve their heart, their tender amity for their fair friend... which the husband seems to be rarely solicitous of" (Manley 157). Edgeworth implies that one wouldn't need a Harrowgate if the world outside allowed women both agency and the opportunity to establish and maintain authentic 
relationships with each other. Harrowgate exists because there is no millennium, no Millenium Hall, no Heaven's gate.

Moreover, Edgeworth's silent refusal to reconcile some of the novel's female rivals or to close with an image of sorority (even in the tableau all the women are embracing men rather than each other) signals a feminist resistance to what she recognizes as the problematics of sisterhood. As recent critics have argued, the narrative of sisterhood, so often held up as the utopic alternative to female competition, all too often works to recover "bad women" into an idealizing framework that flattens out women's subjectivities. ${ }^{137}$ Lady Delacour's questionable reformation, for example, opens up possibilities for behavior not prescribed by domestic ideology. Theoretically, Mrs. Stanhope, never reconciled to her niece, can continue to hawk her feminist ideas for women's economic independence. Mrs. Freke, once her leg heals, might continue to dress in men's clothes. Mrs. Luttridge can continue to turn the tables on men by cheating them out of their money. In much the same way that Edgeworth challenges the banal prescriptions of romantic love, she also calls into question the "characteristic" reformation of wayward women-and perhaps even their waywardness itself. Further, by refusing to suture over the rifts between the women, Edgeworth implicitly indicates the more insistent pull of her narrative - which is not to end in domestic bliss, but to call attention to the terms, conditions, and costs of female rivalry.

\section{Collapsing the Good Girl/ Bad Girl Binary: Edgeworth vs. Lady Delacour}

In closing, I want to consider the ways in which Edgeworth implicitly collapses the good girl/bad girl binary to call into question the feminine ideal established by domestic 
fiction. As already noted, Edgeworth doesn't blame the "bad" girls for their follies, but the misogynist system within which they must operate. However, more than simply excusing their behaviors, Edgeworth also seems to suggest that the "bad" girls aren't really all that bad...nor are the "good" girls all that good.

While Lady Delacour's rival, Anne Percival, that hated "pattern woman" appears to be a "good" girl, she also poses certain ideological problems. Kathryn Kirkpatrick notes that most troubling is her support of Mr. Vincent, testifying to a certain degree of colonialist self-interest bound up in the role of the bourgeois wife. After all, the Percivals depend on their West Indian colonies for financial support. Kirkpatrick suggests that Edgeworth recognizes the ideological potential of idealized femininity and, therein, the problematic connections between gender and nationalist interests. ${ }^{138}$ Lady Anne may have been further troubling for Edgeworth as well as her readers because, as a "pattern woman," she lacks interiority. She seems too closely paralleled to those girls "seemingly cut of the same pattern" who Mrs. Stanhope criticizes. Further, even though her friendship with Belinda is praised in the novel, very little time is devoted to complicating their relationship. Edgeworth devotes much more time to characterizing Lady Delacour's friendship with Belinda—indeed, to characterizing Lady Delacour, period.

Certainly, Edgeworth had problems with her own pattern woman, writing in a letter, "I really was so provoked with the cold tameness of that stick or stone Belinda that I could have torn the pages to pieces" (qtd. in Kirkpatrick xxii). A heroine whom has subordinated all her passion to reason lacks interest for Edgeworth. I argue that Edgeworth, like the novel, gravitates instead to the character for whom the novel might actually have been named—Lady Delacour. In fact, Edgeworth's own sharp wit recalls 
that of the lively Lady Delacour rather than Lady Anne or Belinda, so much so that an acquaintance said of meeting the author for the first time, "What has struck me most today in Miss Edgeworth herself, is her uncommon quickness of perception, her fertility of allusion, and the great resources of fact which I can call nothing else but extraordinary. She certainly talks quite as well as Lady Delacour..." (qtd. in Butler 416). It is no coincidence that in one scene Belinda and Lady Delacour are mistaken for each other at a ball.

Even the residences of the "odious" Mrs. Luttridge and the angelic Lady Anne are brought into proximity. The narrator notes in the description of "domestic happiness" at Oakley Park that within a week Belinda forgets it is "within a few miles of Harrowgate" (217). However, the narrator reminds her readers of its nearness, and, as I argue, routinely recalls their symbolic proximity throughout the novel. A utopia and a dystopia, neither are feasible possibilities in Edgeworth's world, thus both are relegated to the realm of fantasy. Like the good girl/bad girl dyad, their distinction collapses when held up as models. Thus, enabled by the novel's theme of unmasking artifice, Edgeworth plays with notions of identity, collapsing binaries and trespassing boundaries.

Edgeworth is, herself, implicated in this process. The tacit conflation of Lady Delacour with the author occurs repeatedly_to the effect of exposing the anxieties Edgeworth herself experiences for allowing "the rules of the stage," the prescriptions of a patriarchal convention, to guide her hand. Lady Delacour's orchestration of the final scene of the novel quite explicitly aligns the less than perfect character with her author. Both Lady Delacour and Edgeworth devise the close of the novel, and both simultaneously juggle the role of the author with that of the readers/interpreters. An 1810 
letter from Edgeworth to Elizabeth Inchbald makes this connection abundantly clear. She praises Inchbald for avoiding "fine writing," that is, the kind which emphasizes the "manner" or style of writing over the "thing" which is written about; resulting is the privileging of "stage effect" over "nature." Where the author should remain invisible, Edgeworth complains, all too many cannot "bear the mortification of staying behind the scenes. They peep out, eager for applause, and destroy an illusion by crying, $I$ said it; $I$ wrote it; I invented it all! Call me on the stage and crown me directly!" (qtd. in Butler 310). No doubt, the description calls to mind Lady Delacour's insistent orchestration of the novel's close, her presence so very visible, her pride at having volleyed for the right suitor so apparent. Why close the novel with Lady Delacour's voice? Why allow the "stage effect" of the final scene such overt visibility? Although Edgeworth complains of authors who affect such a presence, I argue that she implicitly aligns herself with Lady Delacour-displacing her own desire for applause onto her. Not wanting to peep her own head out of the curtain-humility so much a part of her authorial persona--she allows Lady Delacour to claim the coronet for her.

Edgeworth also implicitly aligns herself with another "bad girl" in the novel, Mrs. Stanhope; both recognize the power inherent in language to construct knowledge. Whereas Mrs. Stanhope uses the marketplace blazon to hawk about her nieces' virtues, Edgeworth relies on the advertisement prefacing her novel to contextualize the significance of both character and novel. She writes in her advertisement, Every author has a right to give what appellation he may think proper to his works. The public have also a right to accept or refuse the classification that is presented. The 
following work is offered to the public as a Moral tale-the author not wishing to acknowledge a Novel. (4)

The very act of writing Belinda as a "moral tale" means that she hopes her readers will mimic Belinda's behavior rather than that of the negative exempla. However, the need for such a model presupposes behavior that does not conform to such expectations. Just as Mrs. Stanhope's girls must learn to play cards, Edgeworth's readers must learn to play Belinda-because, in fact, such behavior does not come naturally. Ironically, although the impetus of the novel is to resist indoctrination, as a "moral tale" it simultaneously suggests that readers need training in proper femininity.

Moreover, Edgeworth's insistence that readers imagine her work as a moral tale rather than a novel bespeaks her awareness of the power of taxonomic discourse to construct knowledge. She recognizes the arbitrary nature of classification systems. Similarly, Mrs. Stanhope calls attention to the artificiality of such labels. She writes to Belinda,

You have every possible advantage, my love: no pains have been spared in your education, and (which is the essential point) I have taken care that this should be known—so that you have the name of being perfectly accomplished. You will also have the name of being very fashionable if you go much into public.... (9)

Mrs. Stanhope recognizes, as does Edgeworth, that classifications depend on subjective perceptions but that we can alter perception through language. Hence, she has "named" Belinda as accomplished in much the same way and to much the same effect as 
Edgeworth names her own work a "moral tale." Ironically, the point of Mrs. Stanhope's letter is to disclose the constructed nature of identity. When Edgeworth acknowledges readers' potential resistance, she implicitly recognizes that the characteristics that distinguish a "moral tale" from a "novel" are arbitrary and up to subjective interpretation. Edgeworth bestows on Belinda the identity of a moral tale rather than novel because, like Mrs. Stanhope, she recognizes the effect of a name on reception-whether or not that name is really an accurate signifier. But Edgeworth's recognition that readers have the right to identify her book any way they please also troubles other waters; if the "truth" of literary classifications is suspect, what about those of gender? What about the dividing line between "good" girls and "bad"? Is the distinction a matter of subjective interpretation?

If Edgeworth self-reflexively admits her lack of semantic control, she also employs tactics to persuade readers of the "rightness" of her model. We witness this contest for ideological dominance in the metatextual wrestling match between narrator and an imagined group of readers for interpretative control. The narrator (arguably Edgeworth's voice) consistently interjects a measure of self-reflexivity about her own role as narrator, jockeying with the readers' skepticisms and assumptions for the right to distinguish fiction from reality. Initially, readers are encouraged to judge the authenticity of this fiction by comparing the experiences of its characters to their own. Of the utopic family scene depicting the Percivals, the narrator admits,

Those who unfortunately have never enjoyed domestic happiness, such as we have just described, will perhaps suppose the picture to be visionary and romantic; there are 
others-it is hoped many others — who will feel that it is drawn from truth and real life. Tastes that have been vitiated by the stimulus of dissipation might, perhaps, think these simple pleasures insipid. Every body must ultimately judge of what makes them happy, from the comparison of their own feelings in different situations. Belinda was convinced by this comparison, that domestic life was that which could alone make her really and permanently happy. (216-17)

It is crucial to note that the interpretative conflict is never explicitly between Edgeworth and a single group of readers; instead, the narrator creates a triangular relationship between herself, her ideal readers (symbolized by Belinda), and a resisting other voice. As Ross Chambers might argue, Edgeworth is trying to drown out the "noise" of the textual function:

Narrative viewed as information passing between duly constituted full and conscious subjects, such as the "narrator" and the "narratee," is discourse controlledwithout residue or error-by those subjects, and, in particular by the narrator as 'originator' of the discourse. Indeed, our recognition of the narratee-role as a product of the narrator's discourse and as constituting a simulacrum of its expected reception is an acknowledgement that the 
narrator-narratee relation contextualizes discourse as a

strictly controlled phenomenon. (33)

In other words, the author controls the meaning of the text by "producing" her narratee (distinct from the "reader" whom she has not constructed and thus cannot control). Although Edgeworth speaks to her readers, her acknowledgement of them is really her construction of an imagined, idealized narratee. She uses the narrator's interpretations to transform uncontrollable readers into controlled narratees. Her control of what the narratee should do or think is how she attempts to edit out any excess information, "noise," or its "textual function," that is, the point at which discursive control breaks down because of a "reader" or reading the narrator hasn't anticipated.

By now, however, we should recognize Edgeworth's tactic as one familiar to female rivalry. She relies on the same strategy of triangulation as her fictional rivalsbonding through the exclusion of a third party, positing herself and her ideal readers as a unified "we" opposed to "those who unfortunately have never enjoyed domestic happiness." Of these latter women she suggests they, themselves, are bad readers and, in fact, bad women—dissipated and insipid. Just as Lady Delacour fairly "bullies" a reluctant Belinda into taking Hervey's hand at the close of the novel, Edgeworth, too, strongly encourages her readers to accept her version of domestic femininity. In an "us against them" strategy endemic to female rivalry, Edgeworth forces her opposition into a corner; they must choose either the naturalness of the Percival family or align themselves with those dissipated. Thus, the metanarrative replicates the good girl/bad girl dyad that composes the novel. Edgeworth utilizes this interpretative competition to create strong bonds between herself and her female readers. Because belonging is so important to 
women, female readers are more likely to "side" with the "we" posited by the narrator and hence conform with group expectations. ${ }^{139}$

Yet simultaneously, Edgeworth recognizes, even calls attention to, the uncontrollability of discourse, the incessant pull that destabilizes the linear relationship she has with her reader in a patriarchal narrative. She is aware and, in fact, makes the reader also cognizant of a proliferation of competing female desires even as she voices loyalty to an either/or dualism. Moreover, if we are to contextualize the triangular mode of narration alongside a female-identified homoerotic triangle, we might also suggest that Edgeworth's exclusion of competing interpretations actually bespeaks her admiration for, and perhaps a primary identification with those voices otherwise figured as rivals.

In sum, in order to do justice to Edgeworth's autho rial complexities, we must learn to listen to the other voices emerging from the gaps in the text. As I have argued here, the rivalry that characterizes her fiction also characterizes her relationship to both patriarchal and feminist ideologies. At one point, Lady Delacour, ever the storyteller, advises Belinda, "Never whilst you live, when you have a story to tell, bring in a parcel of people who have nothing to do with the beginning, the middle, or the end of it" (195). But Edgeworth's moral tale is, indeed, rife with interruptions, gaps, and parcels of people seemingly inconsistent with the plot. These voices pull at the linearity of the narrative, open it up and out, and allow it the sort of uncontrollability and multi-dimensionality that I argue Edgeworth delighted in as a source of feminist resistance. We would be, like an enchanted Lady Delacour, bad readers and critics if we recognized only her allegiance to convention. 


\section{Conclusion:}

\section{Women at Odds, a Continuing Struggle}

Woman against woman—a struggle programmed by cultural computers, an exercise in the squandering of the spirit, a battle that we lose even if we win.- - Letty Cottin Pogrebin, "Competing with Women"

In April 1756, an anonymous contributor to The Universal Visitor responded to the growing presence of women writers:

It is more difficult to know what can be done with the ladies of the pen, of whom this age has produced greater numbers than any former time...I must therefore propose that they form a regiment of themselves, and garrison the town which is supposed to be in most danger of a French invasion. They will probably have no enemies to encounter; but if they are once shut up together, they will soon dis-encumber the public by tearing out the eyes of one another.

The author assumes that female intellectuals pose no viable threat to male authority for they are internally divided, too busy discrediting each other to make any real progress. As feminist critics we should immediately suspect the ideological work of such an assumption. As this dissertation has argued, casting women as inherent rivals has long worked to disable the potential for feminist unity. 
However, women writers in the eighteenth century are, indeed, far from unified. Roger Lonsdale notes in his collection of eighteenth-century poets that these women "often saw other women as even more hostile to their literary ambitions than men" (xxviii). Jacqueline Pearson notes similarly that the most trenchant critics of novels written by women were other women. Consider, for example, Elizabeth Carter, whom Richardson had solicited for advice in writing Sir Charles Grandison. In a letter to the author, she worried about sharing his drafts with other women writers lest they interfere too much in the editorial process. Not only is she exclusively concerned about women readers, but she employs metaphoric language which discloses an internalization of sexist gender stereotypes: "'I apprehend there would be so much scratching \& clawing that it would be impossible to keep him [the character Grandison] in my possession \& he would run some hazard of being scattered to the four winds of heaven'" (qtd. in Eagleton 29). ${ }^{140}$ The enduring image of women's inherent "cattiness" provides us some sense of the ideological power the trope of female rivalry has long wielded over the cultural imagination and, in particular, over women's views of and relationships with other women. ${ }^{141}$

My dissertation has focused on the ways the trope of female rivalry, while maintaining its permanency in literature, shifts in its literary significance depending on who employs it. Yet female rivalry never goes away. While the women writers following Richardson revise literary convention to explore ways in which competing definitions of femininity, as well as competition itself, can be healthy for women, they never entirely abolish the notion that women do compete--perhaps because female rivalry figures so prominently in their real lives. Then, as now, women find that they cannot escape the 
fact of female rivalry, much of it not healthy. We should ask why smart, educated women (writers in the eighteenth century, feminist academics today) continue to fight against rather than with each other? Yet we should also consider whether competition between women is inherently problematic.

\section{I. $\quad \mathbf{1 8}^{\text {th }}$ Century Literary Rivals}

Although the pages of literary history are riddled with stories of rivalries between women writers, for my purposes here, I want to consider three different cases of intergenerational rivalries: Delarivier Manley's scathing depictions of her literary competitors in her roman a clefs, Hannah More's infamous class rivalry with Ann Yearsley, and the highly publicized "feminist controversy" between Anna Barbauld and Mary Wollstonecraft. Of course, underlying all these rivalries is a tacit struggle between competing definitions of femininity, perhaps best symbolized by the century's tendency to assign its women writers to either side of the infamous Astrea/Orinda dichotomy. In what ways did this cultural understanding of proper femininity underwrite these women's relationships with each other? To what extent did these women manipulate the discourse of female rivalry to their own economic advantage? Further, if these women profited from their patriarchal complicity, what was the cost, both personally and culturally?

\section{A Vexed Maternal Heritage: The Astrea/Orinda Dichotomy}

Women writing in the eighteenth-century were not simply struggling against their female contemporaries, but against the women who had preceded them. We see this dilemma crystallized in the infamous Astrea/Orinda construction that pits the scurrilous 
eroticism of writers like Aphra Behn and Eliza Haywood against the chaste modesty of poets like Katherine Philips and Elizabeth Rowe. Explains Jane Spencer, "At the turn of the century Philips and Behn stood together in the public mind: the first gentle and genteel, irreproachable; the second...bawdy in her work, unchaste in her life. Women writers had a choice: Orinda versus Astrea" (29). Significantly, such a choice is a construct specific to the eighteenth-century; before 1700, Behn and Philips would have both been acceptable models for women writers. In fact, most critics agree that Behn's enormous success depended in part on her construction of her authorial self as transgressive. ${ }^{142}$ However, as the conception of femininity shifted in the eighteenthcentury to a more passive, polite model, social rhetoric cast the two as polar opposites. In fact, as early as 1668, even before Behn was published, Abraham Cowley explicitly contrasts the matchless Orinda with "the warlike Amazonian Train" which he hopes “'twill be settled in their Sex by her" (qtd. in Spencer 27). ${ }^{143}$ Behn's erotic works, like Love Letters Between a Nobleman and his Sister, establish her as "bad girl" to Orinda's “good girl.”Paula McDowell concurs, “[B]y the eighteenth century Behn was quickly becoming an anti-model for the new 'literary lady'..." (232). Women writers following Behn found themselves in a precarious position, trying to balance a desire for literary fame (and economic success) with a simultaneous yearning for a female literary heritage. How might women have negotiated this balance?

\section{The Case of Delarivier Manley}

Writing after both Behn and Phillips, Manley faced a dilemma: how to position herself within a female literary heritage. Paula McDowell notes that in Memoirs of 
Europe, Delarivier Manley's “allusions to her female literary predecessor [Aphra Behn] are distressingly derogatory," an effort to distance herself from her less respectable predecessor (234). Although the goddess Astrea, Behn's pen name, appears favorably in Manley's The New Atalantis (1709), McDowell argues that Astrea does not represent Behn but "the new ideal woman writer in her most socially acceptable forms. Chaste and virtuous, and claiming to prefer privacy and retirement, she is in fact remniscent of Katherine Philips" (235). However, McDowell further complicates her reading of Manley's Astrea, suggesting that she often satirizes Philips' idealized purity. ${ }^{144}$ In fact, Astrea seems to suggest a collapse of what is essentially a good/bad girl binary, Manley apparently preferring a figure of femininity somewhere between the two extremes. In this respect, Manley's Astrea allows her to negotiate with, reject, and redefine models of female authorship as well as female behavior.

While Manley negotiates the good girl/bad girl binary, she also employs the trope of female rivalry to discredit her own rivals. She fiercely caricatures Sarah Churchill, the Duchess of Marlborough who was a competitor for Queen Anne's affections as well as a political rival. Churchill is depicted as sexually voracious in The New Atalantis. Manley also lambastes her female contemporaries, many of them close friends until they betrayed her in one way or another. She had once offered patronage to Catharine Trotter, for example, but withdrew support when Trotter defended the Duchess of Marlborough. As Manley's commitment to Tory politics intensified, she became increasingly more critical of Whig writers, especially women. Ros Ballaster notes, "The four women who contributed poems to The Nine Muses of 1700—Sarah Frye Egerton, Mary Pix, Catherine Trotter and Susanna Centlivre - are all satirised in The New Atalantis for both their Whig 
politics and for their disloyalty as friends" (xiii). Often conflating sexual and literary rivalry, Manley depicts these writers as ugly and shrewish.

In The New Atalantis, for example, she describes Egerton: "Nothing was ever so homely. Her face is made in part like a blackamoor, flat-nosed, blobber-lipped. There's no sign of life in her complexion..." (87). Decrying a competitor's lack of beauty is a common strategy of female rivalry; here it works to reduce Egerton's authorial value to her sexual value, or lack thereof because of her physical repulsiveness. In other words, Manley makes clear that Egerton possesses no value on the literary market and is seriously handicapped in an economy that privileges female beauty. Another strategy of female rivalry consists in ridiculing the intellect of one's competitor. Manley relies on this tactic when she lambastes Egerton's lame poetic attempts and pretensions to scientific knowledge; in The New Atalantis Egerton's poor husband laments, "Deliver me from a poetical wife... She rumbles in verses of atoms, artic and atartic, of gods and strange things, foreign to all fashionable understanding" (87). Here Manley challenges Egerton's value as both a wife and a contributor to fashionable discourse. Essentially, Manley strips Egerton of all social worth.

Manley employs yet another strategy associated with female rivalry. As I have discussed, because of cultural constructions of femininity as passive, it was not (and, to large extent, is still not) socially acceptable for women to engage in violent aggression against each other. As the plots of Clarissa, Cecilia, and Belinda all demonstrate, backstabbing, gossip, and other forms of verbal degradation figure as women's weapons of choice. Contemporary studies of indirect strategies of aggression also show that when girls bully, harass and gossip about each other, they often use code names: "The victim 
may suspect but she cannot prove that she is the target" (Chesler 117). These recent studies prove useful when considering Manley's roman a clefs, in which she often relied on code-names to refer to her own literary rivals. Critics like Catherine Gallagher have discussed Manley's use of keys in the context of an alibi to prevent her from charges of libel. Because printers could be sued, they refused to print works which used proper names in personal attacks. Using keys might have been the only way Manley could publish these lampoons. However, I suggest that Manley might have benefited from these restrictions on the press in so far as she could aggressively, yet indirectly, ridicule her opponents and thereby stay — to some degree--within the proper sphere of ideal femininity. ${ }^{145}$ Interestingly, Frances Burney often employed a similar strategy in her writings; in fact, critics suggest that one reason her father discouraged her publication of The Witlings was because its objects of ridicule seemed too closely to resemble members of the Bluestocking circle, Lady Smatter, in particular, an alleged parody of Elizabeth Montagu's pretensions to wit. Both seemed to have reveled in making fun of other women writers and, in so doing, implicitly establishing their own literary authority.

Finally, I'd like to suggest that Manley's lampooning of other women writers speaks to more than the threat they might have posed to either Manley's political leanings or her own literary success. A shrewd business woman, Manley knew the public's taste for scandals, especially those involving female rivals. In New Atalantis, she capitalizes on the readers' desire to see a good cat-fight.

\section{Hannah More v. Lactilla}

Another infamous eighteenth-century example of female competition involves the feud between poets Hannah More and her milk-maid protegee, Ann Yearsley. In brief, 
More, along with Elizabeth Montagu, took the impoverished Yearsley under her wing and encouraged her poetry, mediating between her and various publishers and subscribers. She became enraged when Yearsley insisted on controlling her own money, which More had been giving to her in an allowance. Yearsley, not cowed by More's bullying, complained of her patron's condescending treatment in her poem “To Those Who Accuse the Author of Ingratitude" and her "Autobiographical Narrative." Still, More wielded more literary and class clout and Yearsley never recovered her initial success (Lonsdale 392).

The rivalry between More and Yearsley clearly demonstrates More's desire to maintain clear class distinctions between herself and her protegee. More's outrage implies that Yearsley does not know her proper place; as critics have consistently noted, More, a privileged member of the Bluestocking Circle, worked actively in her many educational treatises to reinscribe class divisions. The public vilified Yearsley's rejection of More's patronage, blaming it on ambition and upstart pride. In fact, Yearsley's actions were a clear transgression of societal assumptions about her success; according to Janet Todd, women like Yearsley, washerwoman Mary Collier, or cook and housemaid Mary Leapor, "knew that they were famous because they were curiosities and tended to stress their lowliness" (Sign 131). Their "lowliness" then, was the condition of their acceptance and patronage by those women of higher social ranks.

One wonders why these women would join forces against another woman writer. After all, they shared what would seem a common experience as women within an oppressive and misogynistic patriarchal society. The answer, however, is simple. By aligning themselves with men against other women, women gain power. Importantly, 
Elizabeth Kowaleski-Wallace comes to More's defense in the introduction of her work,

Their Father's Daughters, noting that most accounts of the feud between More and Yearsley tend to take the latter's side. Kowaleski-Wallace writes of Moira Fergusen's detailing of the incident in First Feminists,

Yearsley is clearly the more sympathetic character, the one who seems more like us in her astute perceptions of gender and class prejudice. Nonetheless, the selection of Yearsley's account has its price, for it means that here woman is set against woman, while the larger cultural context that may have conditioned More's response to Yearsley is not discussed....[W]hat was the connection between More's need to assert 'class privilege' and her particular psychological and cultural needs as a woman within patriarchy?...We must confront the late eighteenthcentury circumstances that allowed More to rise to the heights of bourgeois respectability at the expense of her working-class sisters. (3-4)

Kowaleski-Wallace's examination of More's patriarchal "complicity" is a welcome response to characterizations of her "conservatism." She argues that More's commitment to evangelicalism, as well as her desire to impress father figures, compels her to practice a form of self-identification by defining herself against lower-class bodies whom she works to reform. ${ }^{146}$ Because of their limited access to agency, women are especially sensitive to status instability and all the more protective of ensuring that class boundaries 
remain intact. We saw this in Scott's Millenium Hall, and more fully played out in Burney's Cecilia in which Lady Delvile's allegiance to her family name, because of its symbolic value, interrupts the potential for more genuine relationships with both Cecilia and her son. More needs both to take Yearsley under her wing and experience Yearsley's "rebellion" in order to define her own class position.

Figuring More as the "bad" girl in this feud is, as Kowaleski-Wallace suggests, an oversimplification of the conditions under which both she and Yearsley wrote and lived. However, even as we work to extract More and Yearsley from the good girl/bad girl binary we should ask what More, in particular, might have gained by participating in such a highly publicized feud with another woman writer? In addition to reaffirming class hierarchies, More may have also used their rivalry to position herself alongside male, rather than female, writers. A letter from More to Montagu concerning Yearsley at first seems evident only of More's class prejudices. She writes, "I am utterly against taking her out of her Station. Stephen was an excellent Bard as a Thrasher, but as the Court Poet, and Rival of Pope, detestable" (Landry 301). ${ }^{147}$ More begins by comparing Yearsley to working-class Stephen Duck, the thresher poet, whose writing she approves of only conditionally, as a working-class rather than court poet. Yet More also discounts Stephen's potential as Pope's literary "rival" and, in implicitly aligning Yearsley with Stephen and herself with Pope, More similarly discredits Yearsley as a possible competitor. Her self-assurance, however, can also be read as a sign of self-defense; her rejection of Yearsley as a credible rival discloses her concerns that others might, indeed, dare to compare them. More's reference to Pope works in at least one other way; arguably, she uses the narrative of rivalry to compare herself to Pope - a bold move for a 
woman. In as much, the homosocial rivalry between More and Yearsley works to displace what would be the taboo heterosexual rivalry between More and Pope.

This rivalry worked in other ways to More's advantage. Lonsdale notes that Yearsley's Poem on the Inhumanity of the Slave Trade (1788) was perceived in direct competition with More's Slavery, A Poem (1788), and thus elicited from More more and better writing. Horace Walpole, for example, writes in a 1789 letter to More of his concern at her failure to publish, warning her of rumors, "Hannah will not write, and Lactilla will." (qtd. in Demaria 981). ${ }^{148}$ He continues by blasting Yearsley’s Earl Godwin, but he clearly references the play and the public rivalry to aggravate More, and thereby, urge her to write so as to outshine her protégé. In a diary entry, More laments, "The Peace of my life is absolutely broken by her revenge" (qtd. in Lonsdale 393). Yet More depends on Yearsley's "revenge"; Yearsley is the devilish counterpart to her own angel. More profits by participating in the highly publicized controversy; her constant reiteration of her angst over Yearsley's rivalrous behavior is a process of selfidentification, as well as a plea for public affirmation of her authorial legitimacy.

Even more strategically, More's persistent lamentations over Yearsley's behavior also serve to warn other women writers of the dangers of putting oneself in the public eye. A successful woman writer is, in other words, bound to have competitors and must be more thick-skinned than the general construction of tender femininity allows. The public battle between More and Yearsley thus works to scare other women writers, potential rivals/replacements, from publishing. Anna Seward says as much when she writes a letter to publisher Josiah Wedgewood, 
The charming writer, Miss More, has given the world a poem on the Slave Trade; so has her ungrateful pupil Lactilla. I have not yet seen either of those compositions; but I cannot prevail on myself to give my scribbling foes new opportunity of venting their spleen, by speaking to the world of the inferiority of my attempt to that of the unlettered milk-woman's. So, I am sure, they would say, were I to write as well as Milton on the theme. (qtd. in Breen 48).

Seward's letter recalls Hester Chapone's warning in Letters; lest she experience the poisonous barbs of her own rivals (ambiguously without gender), she will not publish a poem on the slave trade. This, of course, means fewer rivals for More, but by scaring women away from publishing, male power and privilege remains secure.

Nevertheless, I suggest that Seward, like More and Chapone, uses the trope of rivalry subversively. While on one hand she may be relying on the rhetoric of female rivalry to account for her failure to enter the ongoing debate on slavery, she also simultaneously uses it to suggest she could, otherwise, produce a poem to rival Milton. She posits, in other words, an imaginative place for female accomplishment. In the same way that More aligned herself with Pope, Seward aligns herself with Milton—and both imply that women's potential to rival men is forestalled by their preoccupation with female rivals. 
As the century progressed, a radical femininity became temporarily popular, due in part to talks of social and political revolution inspired by the French and American revolutions. The late eighteenth century is characterized by what has come to be known as "the Feminist Controversy," emblematized by the oppositional dyad of Anna Barbauld and Mary Wollstonecraft (a reinvention, it would seem, of the Astrea/Orinda binary). Here, however, the two contemporaries participated in the rivalry. In contrast, Behn and Philips had never written to or about each other; their rivalry was constructed entirely through the public imagination, the women signifiers more than historical figures. Wollstonecraft and Barbauld, however, waged a sort of literary war, criticizing each other in their individual works. One might read this "war," however, as a debate between competing versions of femininity, and the women as active negotiators rather than passive signs.

In Vindication, Wollstonecraft takes Barbauld to task for her contributions to what she decries as the "false system of manners" taught to women by conduct books and polite literature. In fact, she explicitly references Richardson's misogynistic treatment of Clarissa and what she sees as his unhealthy definition of feminine virtue. Wollstonecraft derides the valorization of "feminine" behaviors associated with passivity and vulnerability, complaining of an ideology which "robs the whole sex of its dignity, and classes the brown and fair with smiling flowers that only adorn the land. This has ever been the language of men, and the fear of departing from a supposed sexual character, has made even women of superior sense adopt the same sentiments" (144). She footnotes Barbauld's poem, “To a Lady With Some Painted Flowers," which likens women to flowers and advises female readers: "your sweetest empire is—to please." A dismayed 
Wollstonecraft asks her readers, "[H]ow could Mrs. Barbauld write the following ignoble comparison?" (144). It is bad enough, says Wollstonecraft, that a masculinist ideology promotes women's subordination; it is worse that other women would aid its cause. In other words, Wollstonecraft not only offers an alternative version of femininity to her readers, but she argues that women like Barbauld work against, rather than for, women's dignity.

An indignant Barbauld responds to Wollstonecraft's Vindication with “The Rights of Woman" (1795). ${ }^{149}$ The poem opens up by mimicking Wollstonecraft's imperative tone:

Yes, injured Woman! Rise, assert thy right!

Woman! Too long degraded, scorned, oppressed;

O born to rule in partial Law's despite,

Resume thy native empire o'er the breast! (lines 1-4)

Barbauld's poem is clearly satirical. That she asks readers to assert an "empire" over their breasts is in direct response to Wollstonecraft's "radical" proposal in Vindication that women nurse their own children. In as much, Barbauld trivializes Wollstonecraft's argument. She depicts Wollstonecraft as an Amazon, armed with "bright artillery" (10) and a voice like a "thundering cannon's roar" (11), whose purpose is to "Make treacherous Man thy subject, not thy friend" (19). Barbauld accuses Wollstonecraft of proposing a society in which women rule, warlike, over men; she misrepresents Wollstonecraft's driving argument, which is the necessity of friendship between husbands and wives. Barbauld closes the poem suggesting that love will change the Amazonian woman: "Then, then, abandon each ambitious thought/...In Nature's school, 
by her soft maxims taught/ That separate rights are lost in mutual love" (29-33). Barbauld rejects Wollstonecraft's agenda as naïve radicalism, embracing instead domestic ideology's version of femininity whose empire is the heart. Barbauld, who once wrote that "There is no bond of union among literary women" (qtd. in Lonsdale 300) clearly saw the need to be at the side of men, rather than women.

Of course, Wollstonecraft raises the ire of writers besides Barbauld, symbolizing as she does sexual transgression and the radicalism from which so many women writers so desperately tried to distance themselves. In Strictures Hannah More calls Wollstonecraft's works “cool, calculating wickedness.” (qtd. in Kowaleski-Wallace 43). Writers like Mary Hays and Mary Robinson are lumped in the toxic cabal of Wollstonecraftian devotees, even though Hays, who edited an 1803 volume of intellectual women, fails to mention Wollstonecraft, perhaps as a way of distancing herself from her (Brody 59). The tragic failure of the French Revolution did little for Wollstonecraft's reputation—she had, after all, ardently supported the revolution in the beginning. Moreover, after her death and Godwin's publication of her steamy love letters to Gilbert Imlay, she became an even more conflicted model for Victorian women. Victorian writer Harriet Martineau would say that Wollstonecraft was not "a safe example" and that "women of the Wollstonecraft order...do infinite mischief, and for my part, I do not wish to have anything to do with them" (qtd. in Mellor and Matlak 33). Barbauld, on the other hand, would have been considered an acceptable model of femininity. However, we should be as careful with the Wollstonecraft/Barbauld opposition as with the More/Yearsley to avoid simplistic binaries. Contemporary feminists might be tempted to write off Barbauld, like More, as "bad" girl; however, we 
need to consider the conditions framing both her patriarchal complicity and her anxious response to Wollstonecraft's proposals. We need to ask how she, like More, might have used the trope of female rivalry subversively to support her own literary ambitions.

\section{The Angel in the House of Higher Learning: Academic Feminists vs. Each Other and "Housewives"}

The implications of my own study resonate for what I see as the problematic, even rivalrous relationship between feminisms within academia, as well as a growing antagonism between academic feminisms and women outside academia. I think we can draw connections between the divisive impulse in the literary and critical history of eighteenth-century women's writing and the tensions today. In closing, I want to consider briefly our inheritance as feminist scholars in academia, the ways in which we tend to replicate contests between feminisms and femininities. Yet I argue for the need to self-reflexively keep these "rivalries" in play.

Women in the Academy: Competing Feminisms, Rivalrous Feminists

Women academics today continue to face many of the same problems as their ancestors. We find ourselves vying for limited positions and delimited power, embroiled in class rivalries, and still unsettled as to how to define either proper femininity or proper feminism. Donna Landry and Gerald MacLean, authors of Materialist Feminisms (1993), offer a useful history of the evolution of feminism in the United States and Britain, concluding that feminism has been largely commodified and, women, both inside and outside the academy, thus kept in a perpetual state of rivalry. Identifying what they see 
as the effect of feminism's institutionalization, they argue that the use value, or emancipatory potential, of feminism has been subordinated to its exchange value (i.e, what is most popular at a given time) on the academic market. Feminisms seem interchangeable and rival each other for academic turf by declaring their claim on "true" feminism, what MacLean and Landry term the "purity policy." Indeed, as one camp of academic feminists rallies against another and accuses their politics of not being "feminist" enough, or of being "too" radical, we seem to be participating in a reincarnation of the hegemonic "divide and conquer" stratagem of the culturally constructed Orinda/Astrea rivalry.

Academic feminists seem further alienated from each other by the demands of the market. A clear class system has remained in tact, positioning faculty against each other on the basis of from what college they graduated or at which college they are working. Further, graduate students preparing for the job search learn to think of themselves as marketable commodities, vying for publication space and conference seats, and strenuously working towards more and more degrees by which they can "one up" the competition. These competitive feelings may be doubled for women of color, who perceive that they are competing with other women for a token "minority" position. ${ }^{150}$

While both men and women face these problems, I suggest that women feel more intensely the pressures of competition. Women are generally socialized to behave less aggressively than men, who from boyhood are rewarded for competitive behavior as testament of their masculinity. Similar behavior in girls is punished or looked down on; hence, as studies have shown, women tend to avoid direct confrontation. According to 
one university study, women will even laugh at jokes they do not find funny to avoid hurting the teller's feelings.

Female academics are further taught that to compete with another woman is to somehow betray the purpose of feminism, to betray our "sisters." Evelyn Fox Keller and Helene Moglen, in an article entitled "Competition: A Problem for Academic Women," begin their essay with references to the threats, explicit and implicit, they fell victim to when discussing the project. Other academic feminists, it seemed, did not want to acknowledge that they competed with each other; Keller's and Moglen's exposure of the dark underbelly of academic competition was regarded as a vicious betrayal. The authors suggest that the problem is deeply rooted and extraordinarily complex:

Not only have feminists inherited a mythology of sisterhood that fits poorly into a world of scarce material and emotional resources, we have found that sisterhood itself—real or mythic—is often inappropriate to our circumstances. Some times we are mothers, sometimes daughters, sometimes lovers, sometimes friends. Each of these roles is split into good and bad. None of these relationships can be cleansed of the threatening feelings of envy and resentment—even of the "killer instinct"- that we associate with competition and have tried so hard for so long to banish from our image of ourselves. (23)

Yet despite our disillusionment with the promise of feminism and sisterhood, we do not openly discuss our feelings. We continue to pretend we are not competing, do not see 
each other as rivals, are not implicated within a hierarchy system. To admit we are divided is, no doubt, dangerous, to our conception of what it means to be women, feminists, and allies in the same struggle.

Stories of such rivalries are innumerable. Leora Tannenbaum, author of Cat Fight, records an interview with a female graduate student accused of stealing ideas from her female mentor, with whom she had taken a class. The student suggested to Tannenbaum that the mentor might have been more protective of her own ideas since she still felt less respected, by virtue of her sex, than her own male colleagues. Similarly, economics professor Ivy E. Broder suggests "[W]omen may believe that, unless they judge other women harshly, their own credibility will be questioned" (qtd. in Chesler 336). Keller and Moglen, both professors, suggest that female faculty continue to perceive themselves as less respected, but may feel this way because they have bought into stereotypes about female powerlessness. Additionally, they may indeed have vexed feelings about female graduate students who want to look toward them as not just mentors, but "mommy" figures. No doubt, female professors often complain that students, in general, expect from them more nurturing than from their male colleagues. Expectations for female faculty continue to differ from those for males in a variety of ways, increasing the stress on women who compete with each other for academic jobs. Recently I attended an academic conference and, at a luncheon, had the opportunity to converse with several other female graduate students and newly hired assistant professors about the job market. I was not surprised to hear that, during a mock job-interview, one woman had been advised by her all-female dissertation committee to cut her hair so that it looked less "messy" and to avoid laughing "girlishly." Several of 
the other women sitting at the table noted that they had been similarly warned about appearing too feminine at interviews. We wondered aloud if men are advised to curtail their "boyish" laughter. It made me think of a female colleague where I teach who is currently a part-time instructor but vying for a full-time position. A few hours before her interview she stopped by my office to ask my opinion on her outfit: was it too feminine? Should she change into pants? What would the other women be wearing? What did I wear when I interviewed? (After toying with the idea of wearing a skirt, I had opted for a pantsuit). On the other hand, my husband's concerns about which tie to wear to his interview at the same school a few years ago was never about what was too masculine or too feminine. I think these anecdotes succinctly demonstrate that women go into the job search with an additional and distinct set of concerns. We are competing as academics, but we are also competing as women. And what it means to be the "right" kind of woman, the desirable kind of female colleague, in the academy is still decidedly vexed. The struggle among women faculty becomes particularly difficult for those who may want to start a family. Because most women are in graduate school or even coming up for tenure at exactly the time in which they can most healthfully have children, women more so than men are forced to make difficult personal decisions. A woman who decides to prioritize around her biological clock may find herself resenting colleagues who have more time to devote to their studies. Those same colleagues, busily working to publish, attend conferences, and vie for positions, may resent her for reminding them of an undeniable biological imperative. They may write her off as unenlightened, tootraditionally minded, less focused than they; she may in turn feel isolated and depict them as slaving under a masculinist work ethic. 
Ironically, rivalry in the workplace may, in fact, be particularly salient for women following the gains of 1970's feminism. Writes Naomi Wolf,

It was one thing to experience a loss of self in a pre-

feminist culture that at least assigned a positive status to motherhood itself; it is a very different thing to lose a part of one's sense of self to motherhood in a world that seems to have little time, patience, or appreciation for motherhood or parenting. This is especially hard for women who have struggled to be independent and self-reliant. At the birth of a first child, the expectations of our generation collie with what is too often a radical social demotion in a culture dismissive of mothers and babies and contemptuous of what they really need. $(8)^{151}$

Instead of working together to support each other's choices, perhaps rallying for the right to longer maternity leave, for better child-care options, for greater male participation in family-raising,- - women choose to resent each other and go it alone. ${ }^{152}$

Keller and Moglen's study, nearly twenty years old now, nevertheless rings true. While many of the pressures they discuss - the small number of women who are tenured professors, for example_-no longer seem as relevant, the reality of competition remains. Women must compete with each other in order to survive in the academy... and yet to do so naturally instills in many of them feelings of guilt and shame. Acknowledging these feelings, however, and finding a way to compete healthfully and openly seems a significant step in the right direction. But how might one compete with another woman 
without using the indirect strategies of aggression discussed in this dissertation? Valerie Miner, discussing her vexed feelings about competition between women in the world of publishing argues for "cooperative competition" in place of masculinist competition:

Cooperative competition creates a better feminist literature.

We use each others' work as models for achievement. We see each others' success as a promise of our own...

Cooperative competitors eschew the veils and acknowledge the vicissitudes of publishing—by fighting for our rights as workers; by challenging the sexism and racism of publishing; by providing a critical forum in which all our work is taken seriously. Now we don't have control over our books, but we do have control over our attitudes about our books and each other's books. And we can 'strive together toward' by inciting each other to be better writers and readers. (193)

While Miner's focus is on the world of publishing, and many of her concerns specific to the pressures faced by fledgling writers, her proposal for "cooperative competition" also translates for women in the academy who face many of the same pressures. We may not have control over the market, over how many jobs are available, about what kind of "feminist" or "feminism" hiring committees or publishing houses are looking for at the moment; however, we do have control over how we treat each other. ${ }^{153}$ In fact, her suggestion for "cooperative competition" sounds a lot like Sarah Scott's plan in Millenium Hall in which women vie with each other, but to the betterment of their 
community as well as their own intellectual and moral growth. I might echo Irigaray here: "Utopia? Perhaps." However, arguably, worth a try.

But what about those outside the house of higher learning? Clearly, the mandate to treat each other well, even when competing, should extend to women not in the academy. In the last ten years, various presses have issued a spate of works focusing on the very issue of rivalries among academic feminists. Among topics of concern are how to avoid essentializing what it means to be a woman or feminist while still making room for the inclusion of non-Eurocentric, non- middle-class voices. Says Linda Alcoff, "Feminist scholarship has a liberatory agenda that almost requires that women scholars speak on behalf of other women, and yet the dangers of speaking across differences of race, culture, sexuality, and power are increasingly clear to all" (286). She continues, $[T]$ he practice of speaking for others is often borne of a desire for mastery, to privilege oneself as the one who more correctly understands the truth about another's situation... And the effect of the practice of speaking for others is often, though not always, erasure and a reinscription of sexual, national, and other kinds of hierarchies. (306)

For many academic feminists, the desire to speak on the behalf of their oppressed, less enlightened "sisters" has lent to such troubling tendencies as the ideological construction of a "pure" feminism, of the hallowing of an "angel in the house" of higher learning. This has had the negative consequence of positioning women outside the academy as in need of psychic rescue, in essence, as madwomen. In other words, we have flipped the 
binary: the "bad" girls are now those who resist academic feminism; the "good" girls are those who strive to convert women outside the academy.

But there is an inherent problem with this mission—or at least the way in which we have approached it. Christina Hoff Sommers argues that gender feminists who see the problem as ideological have "stolen" feminism from equity feminists, who are content with policy changes. Among their abuses, says Sommers, gender feminists have muddled the canon, alienated men, and oppressed mainstream women. I find much at fault in Sommers' argument, including her flattening out of the landscape of academic feminism, naïve denial of women's institutional oppression, and hostile attack on women's studies. However, she is absolutely on target in identifying an acute problem in academic feminism: a sense of superiority over women outside of the academy who do not recognize a prescient need for ideological transformation. For example, women who have opted to stay home and care for their children rather than enter the workforce (an increasingly popular choice), ${ }^{154}$ often feel threatened, even attacked, by a feminist ideology which they cannot understand-primarily because they are exposed to it only through the media's distortions. ${ }^{155}$ Many of these women may continue to identify with Barbauld's notion of woman's rights—-that "mutual love" between men and women will ultimately abolish any sense of inequity. Of course, we differ in defining what that mutual "love" should entail.

How do we make academic feminisms (for they should be understood pluralistically) more approachable, even more engaging, for women outside academia, an agenda that so far seems to have failed? Even the smart, educated young women in our classrooms consistently preface discussions with a familiar rejection of feminism: "I'm 
not a feminist, but...." I don't think we can ent irely blame this antagonism on the media and ignorance. I argue that academic feminism is also responsible for failing to connect to the needs, values, and experiences of women outside the academy. After all, how does a woman without access to the MLA bib liography, who doesn't even know what the MLA is, ever really get to hear what women within the academy have to say? One might ask alternatively, how many academic feminists read mainstream journals and newspapers, or have the kind of contact necessary with women outside of the academy to really get a sense of what they have to say?

Yet I do not think it is the responsibility of academic feminism to find ways to transform women outside the academy so as to make them "fit." Women inside the academy must be careful not to look down on those outside its walls, some of them from less privileged classes, lest we replicate a Hannah-More like syndrome. But we must also be cautious about assuming that education is the ticket to their intellectual freedom; there are plenty of women graduating from college, even from graduate school, who are adamantly "conservative." Writing them off as hopelessly brainwashed is surely no way to negotiate our differences. We must not be satisfied with identifying ourselves simply in opposition to the "other woman" of the mainstream public, but look for ways in which to bridge our differences. We must also recognize the validity of each woman's political choices, and instead of (Manley-style) lampooning women whose politics differ from ours, spend more time investigating the reasons underlying those choices... as well as always exploring our own. Embracing the pluralism implied in the term "feminisms" (in contrast to a monolithic 'feminism' that positions all outside its ring antagonistically) is 
one step towards ensuring a sense of sorority able to welcome, not simply 'tolerate,' different kinds of women and women's experiences. ${ }^{156}$

\footnotetext{
${ }^{1}$ For a discussion of female rivalry in Greek mythology and fairytales, see Phyllis Chesler, Woman's Inhumanity to Woman. See also Ann and Barry Ulanov, Cinderella and her Sisters: The Envied and the Envying for an interesting theological discussion of gender's relationship to envy and goodness. For work on rivalry between biblical women see Judith R. Baskan, "Women at Odds: Biblical Paradigms."

${ }^{2}$ See Susan Lanser, "Befriending the Body: Female Intimacies as Class Acts," Helen Ostovich, “'Our Views Must Now Be Different': Imprisonment and Friendship in Clarissa," and Janet Todd, Women's Friendship in Literature. .See also Maids and Mistresses, Cousins and Queens:
} Women's Alliances in Early Modern Literature, eds. Susan Frye and Karen Robertson.

${ }^{3}$ Phyllis Chessler writes about the hostile reaction with which her book, Woman's Inhumanity to Woman, met. In her introduction she says, “A peculiar silence surrounds woman's inhumanity to woman. Feminists have remained silent; I have remained silent. It is simply too painful to remember one's own betrayal at female hands, too difficult to analyze the ways in which women-myself included, collaborated in the undoing of other women" (25). Similarly, Valerie Miner and Helen E. Longino begin their work, Competition: A Feminist Taboo, with an account of the resistance with which their study met and the difficulties they encountered writing it: "It is painful to admit the deep rivalries we have had with sisters and mothers, just as it is embarrassing to point to our competition with other women in the workplaces, neighborhoods, and political groups" (1). I address at greater length the problem of sisterhood in my conclusion.

${ }^{4}$ For a discussion of the problems inherent in idealizing sisterhood see Helena Michie, Sororophobia. See also my discussion of Sarah Scott's Millenium Hall and my conclusion.

5 Among the works I rely on are Chesler's Woman's Inhumanity to Woman, Donna Landry and Gerald MacLean's Materialist Feminisms, Helena Michie's Sororophobia: Differences Among Women in Literature and Culture, Valerie Miner's and Helen E. Longino's Competition: A Feminist Taboo, and Susan Ostrov Weisser's and Jennifer Fleishner's Feminist Nightmares, Women at Odds: Feminism and the Problem of Sisterhood.

${ }^{6}$ Janet Todd traces at length the evolving figure of woman in conjunction with corresponding social and political changes which I discuss here in brief. For her more extensive discussion, see Janet Todd, The Sign of Angellica: Women, Writing and Fiction, 1660-1800. 
${ }^{7}$ For further discussion of misogynist treatment of women in literature see Felicity Nussbaum, The Brink of All We Hate: English Satires on Women 1660-1750.

${ }^{8}$ I am using "public" in the sense employed by Jurgen Habermas in The Structural Transformation of the Public Sphere.

${ }^{9}$ See Janet Todd's discussion of women's participation in politics in The Sign of Angellica. For more about women's participation in politics prior to this shift, see also Paula McDowell, The Women of Grub Street: Press, Politics and Gender in the London Literary Marketplace, 16781730.

${ }^{10}$ See Thomas Laquer's Making Sex: Body and Gender from Greeks to Freud.

${ }^{11}$ See Mary Poovey, The Proper Lady and the Woman Writer for a larger discussion of how Puritanism institutionalized a figure of woman able to resolve paradoxes inherent in domestic ideology.

${ }^{12}$ See Elizabeth Kowaleski Wallace's discussion of "new-style patriarchy," a seemingly kinder, but no less oppressive version of gender ideology.

${ }^{13}$ Literary critic Jacqueline Pearson, author of Women's Reading in Britain, observes that more women than men devoted energy to categorizing literature.

${ }^{14}$ For an extended discussion of the rise of literary criticism of the eighteenth-century novel see Ellen Gardiner, Regulating Readers: Gender and Literary Criticism in the Eighteenth-Century Novel.

${ }^{15}$ Poovey uses the term "doubling" to refer to the technique by which both male and female authors enable their heroines to explore vicariously transgressive desires and experiences through the negative exempla. Poovey does not, however, consider the psychic effect of doubling; that is, she does not consider the problems created by the trope of female rivalry itself. See The Proper Lady and the Woman Writer.

${ }^{16}$ Kowaleski-Wallace's interpretation of women's patriarchal complicity uncovers the psychological trauma of their struggle with competing desires and the need to use negative exempla which can contain "aberrant” female sexuality. Similarly, Kristina Straub's Divided Fictions: Fanny Burney and Feminine Strategy works to reveal the psychic crises experienced by Burney as she defers to patriarchal authority. Straub examines what she sees as gaps or inconsistencies in the texts' coherence, made more clear in the progression of Burney's work as she increasingly refuses to gloss over her anxieties. See Poovey for a discussion of the ideological contradictions disclosed in works by Wollstonecraft, Shelley and Austen.

${ }^{17} \mathrm{I}$ am, of course, echoing Judith Butler in Bodies that Matter. 
${ }^{18}$ See Armstrong, Desire and Domestic Fiction and Chapter One of Paul Hunter's Before Novels for extended discussions of the novel's didacticism and its relationship to women readers.

${ }^{19}$ Helene Moglen attempts to make visible narratives of "mourning" otherwise obscured by realism. Her work discloses ways in which the novel's realism papers over inconsistencies in social fictions.

${ }^{20}$ See Paula Backscheider's introduction to Revising Women.

${ }^{21}$ See Jane Spencer, The Rise of the Woman Novelist.

${ }^{22}$ See Sylvia Harcstark Myers, "Bluestockings in Print and on Canvas."

${ }^{23}$ Janet Todd discusses the culture's inability to distinguish between women's autobiographical lives and their literary productions and the ways in which women like Behn and Manley exploited this conception of female authorship. See The Sign of Angellica.

${ }^{24}$ Of course, Brown argues that gossip among women in colonial America usually worked to reinscribe patriarchal values. Fear of being gossiped about compelled women to conform to "proper" feminine behavior. Nevertheless, gossip had a "leveling potential" to bring together women of different classes and races, granting it a degree of subversion (89). See also Patricia Meyers Spack's work, Gossip.

${ }^{25}$ For further discussion of rivalries between women writers in the eighteenth century, see my conclusion.

${ }^{26}$ For a lengthier discussion of women readers' responses to Richardson's Clarissa, see Ruth Perry, “Clarissa’s Daughters.” Also, see Elspeth Knights's work.

${ }^{27}$ Apparently, not always with their permission. Both Knights and Perry notes that some of his women readers accused him of exploiting their personal tragedies.

${ }^{28}$ Hilary Schor, for example, has argued problematically that Clarissa's rape is symbolic of her triumph (105), marking the novel as representative of "nascent feminism" (111). Anthony

Winner has suggested that Richardson is a "Christian, not democratic, feminist" (48), and Kathryn Kittredge claims that for Richardson, Clarissa is a Frankenstein-like creation, a project designed to confront social problems, specifically oppressive gender prescriptions, but one which he is ultimately forced to destroy. Terry Eagleton, although readily admitting to Richardson's paternalistic tendencies, nevertheless suggests that Clarissa's death "signifies... an absolute refusal of political society: sexual oppression, bourgeois patria rchy and libertine aristocracy altogether" (76).

${ }^{29}$ Koehler relies on Michel Serres' notion of discourse as triangular: between a writer and a reader who collude to exclude interference by a third party (a conflicting interpretation). She also 
depends heavily on Ross Chambers, who suggests that the author is always in the position of trying to exclude the "textual function" of narrative discourse, that is, the "'readerly" act of interpretation" (156). Koehler argues that Richardson manages to "extract a binary model of communication from an implicitly triangular one" (154). In other words, Richardson succeeds in controlling the parasitic third party - the unintended message, or "textual function," created by the readers' interpretation of the text. He must "purge" the communication of this unwanted "noise." He creates his own reader. However, Koehler argues that while Richardson relies on triangular discourse, that he also "transcends" it. Just as Lovelace attempts to censor letters and control discourse so, too, does Richardson try to exclude "parasites and "noise"" (160). Richardson does this, in part, through the creation of third-party outsiders (Arabella, the Sinclair Household, and even Anna) whose interpretations must be rejected in order to establish a binary communication between narrator and narratee.

${ }^{30}$ Even Mary Rowlandson's account of her captivity by Native Americans in colonial America seems to concentrate on the tyranny she experiences at the hands of jealous Native-American women. While Armstrong ("Reclassifying”) discusses links between captivity narratives and Clarissa, she does not note the themes of female rivalry which figure so prominently in both.

${ }^{31}$ Anna Howe and Mrs. Norton seem to be exceptions to this rule but, as I will argue, also prove problematic for Clarissa as sites of female intimacy and refuge.

32 Thomas Coram's building of the Foundling Hospital in 1739 speaks to an explosion in infant abandonment.

${ }^{33}$ All references are to the Penguin edition. For a convincing argument against using the Sherburn abridged version, see Margaret Ann Doody's and Florian Stuber's co-authored article, "Clarissa Censored."

${ }^{34}$ See, for example, Michael McKeon and Nancy Armstrong.

${ }^{35}$ Terry Eagleton, of course, has argued for its phallic significance.

${ }^{36}$ See Phyllis Chesler, Chapter 3.

${ }^{37}$ I am speaking not only of the eighteenth century; according to several cross-cultural studies, more than half of women interviewed support the notion that abused women deserve their abuse. Social psychologist Gloria Cow an explains “women's hostility toward other women can be thought of as internalized oppression or false consciousness" (qtd. in Chesler 150).

${ }^{38}$ Castle does not examine this scene in detail, although she does make passing reference to it when she notes ways in which others consistently try to close up or shut Clarissa's mouth. Castle's analysis focuses mainly on the ways in which Clarissa's speech/writing is read as 
rebellion by those around her and how the narrative drive is to enable Clarissa to recognize that what she interprets as "natural" is only a "linguistic construct" arbitrarily imposed by society. Castle argues that Richardson's novel is able to bring into contact conflicting interpretative modes and expose masculinist interpretations as problematic. Clarissa comes to see her world as "halved": "sign and nature split apart" (59).

${ }^{39}$ Lois Chaber, for example, argues that Clarissa constructs herself as a martyr, and that Richardson's view of femininity is as passive Christian masochism.

${ }^{40}$ Says Phyllis Chesler of studies of female rivalry, "Girls learn that there is a "danger in authentic encounters' with other girls. Girls learn how not to disagree or fight in direct or confrontational ways" (95).

${ }^{41}$ Laura Hinton notes that the plot of the novel drives Clarissa into increasingly smaller spaces (from closets ultimately to a coffin), yet Hinton argues that Clarissa is a sadomasochist who controls the behavior of others through moral aggression. According to Hinton, she uses her suffering to engage sympathy; in fact, says Hinton, Clarissa needs Lovelace's sadistic behavior against which to assert her own suffering. While I agree with Hinton that Clarissa ultimately possesses no tangible agency, her actions always already underpinned by patriarchy, I think that what Hinton notes as sadomasochism with Lovelace is, in the context of her relationship with women, better read in its larger context as a component of female rivalry.

${ }^{42}$ See Bloom, p.10.

${ }^{43}$ The same is true for James, who largely disappears into the background, surfacing only now and again to spit venom at his sister. It is Arabella's poisonous behavior, however, which is the most sustained and which seems the more painful for Clarissa to experience.

${ }^{44}$ Anthropologist Marjorie Harnes Goodwin's studies of rivalries between women suggest that instead of physical violence, girls "embark on a campaign to enlist others into their own private army of righteous indignation,...targeting another girl for exile or confrontation" (qtd. in Chesler 112). Because belonging is eminently more important to women such alienation can be devastating. Another anthropologist, Christina Salmivalli, found that "as the bullying continues, the unfortunate victim is increasingly perceived as 'deviant, worthless... as deserving of being harassed"" (qtd. in Chesler 114).

${ }^{45}$ Katharine Kittredge has argued that Richardson actually sanctions, even calls on, a certain level of permissible androgyny, but also notes that both men and women "must be careful not to undercut their own primary sexual identification” (21). Indeed, Mrs. Sinclair, Mrs. Jewkes, and Betty Barnes are hyper-masculinized, and thus monstrous. Kittredge does not address, however, 
the important issue of class in relation to which women transgress gender boundaries; Arabella may act violently when angry, but she is otherwise ladylike in her mannerisms. We cannot say the same of the "working-class" women of the novel.

${ }^{46}$ Janet Todd, in the first chapter of Women and Friendship in Literature, has noted the parallels. She states, "The terrifying Sinclair may seem far from the weak and submissive Mrs. Harlowe, but their functions collide; both women minister to men and preside over houses whose genteel veneer barely hides the brutality beneath" (35). Although Todd is more interested in the portrayal of the friendship between Clarissa and Anna, she uses Clarissa's relationships with these other women as a point of contrast. However, Todd implicitly assumes that the depiction is a critique of a society that pits women against each other; further, she just as easily parallels Lovelace with Mr. Harlowe in suggesting that Richardson is condemning patriarchy and its stooges.

${ }^{47}$ For a discussion of the "clues" of facial features, see Robert W. Jones. "Obedient Faces: The Virtue of Deformity in Sarah Scott's Fiction.” Jones notes,

Works by Fielding, Richardson, Mackenzie, and Sterne all feature prominent descriptions of the faces of major players that the reader was expected to understand in terms that are ultimately more ethical than physical. The semiotics of character is more often applied to women: witness...the scrupulous attention to appearance that determines the presentation of Clarissa and Pamela. To the eighteenth-century novel reader skilled in the nuances of such pictorialism, if a woman's face was formed in one way it might denote her sly and grasping nature; if shaped in another, presumably more pleasing way, it would reveal her to be chaste and modest; perhaps an eligible match or a worthy mother...[I]n a society in which encounters between young men and women remained highly regulated, physical appearance was one of the few indicators available to intending marriage partners. The ability to distinguish between the face of the scheming coquette and the visage of a virtuous woman was therefore a skill thought advantageous to a young man's education. (281)

See also Barbara M. Benedict, "Reading Faces: Physiognomy and Epistemology in Late Eighteenth-Century Sentimental Novels.” 
${ }^{48}$ Unlike Sinclair, their names are not immediately meaningful, however Rosemary Bechler suggests the names of Sally Martin and Dorcas Martindale are owing to Richardson's acquaintance, Benjamin Martin, the leading natural philosopher of the eighteenth-century. Richardson's doctor, John Freke and Martin had apparently been quarreling about the nature of fire. Freke had referred to Martin as among those "quack and illiterate pretenders" who practiced the "vile prostitution" of science. Thus, suggests Bechler, these prostitutes allegorize a greater battle being waged about the nature of morality. The fire scene is thus all the more significant because it is not a "real" fire.

${ }^{49}$ Janet Todd, in Women's Friendship in Literature, outlines four ways in which Lovelace schemes to interrupt their friendship: by tampering with her letters, menacing her friends, reconstructing the women in her life as monstrous, and, finally, by blatantly attacking the idea of female friendship.

${ }^{50}$ Moore is revising Lillian Faderman's claim that “[d]iscouragement of romantic friendship seems to have been rare, not only because society believed that love between women fulfilled positive functions such as providing a release for homosocially segregated girls and unhappily married women, but also because men generally doubted that these relationships would be enduring in any case" (77). Moore effectively demonstrates, as has Susan Wahl, that such romantic friendships did inspire demonstrable anxieties, but that some authors were able to express les-than veiled homoerotic desire in their works.

${ }^{51}$ Several critics have examined this passage. Janet Todd notes of Morden's praise of the friendship between Anna and Clarissa, that it is in the past; "The present is reserved for his arrogant inference about women of sense and for marriage, the actual relationship to which women must and should submit" (Women 68). Yet Todd suggests that Richardson's view of female friendship is, ultimately, ambivalent—whereas I am arguing he finds it directly threatening. Lillian Faderman has argued that the scene is indicative of a tacit approval of female friendship, because of the view that it was, by nature, temporary (77). It is, in fact, from this scene which she draws her title.

${ }^{52}$ Martin Price calls Lovelace a restoration comedy libertine who scorns the hypocrisies of the world and its artificial hierarchies (34). Thus, he feels Clarissa is justified in desiring him, and that her desire signifies a rebellion against bourgeois hypocrisies. Similarly, Anthony Winner suggests, "Theoretically, Lovelace offers freedom from bondage and a joint rebellion against the enslaving world" (44). He continues, "Since family and society have degraded Clarissa intro property, Lovelace's idealization of her as property appears a relative improvement" (45). 
Embracing Lovelace as a hero figure, Winner argues that "Richardson's celebrated empathy with feminine premises and psychology is carried over into Lovelace, who joins the traditional emotionalism of women to masculine force" (47). Yet Lovelace's essential flaw is that he is more passionate than rational. He becomes a "monstrous" version of the eighteenth-century female Quixote (47). Alternatively, Tassie Gwilliam has identified parallels between Richardson and Lovelace, noting that both cross-dress (Richardson only metaphorically as he writes from a woman's perspective). Gwilliam argues,

It is possible to see in Lovelace the representative of an old order confronting a new ideology: His rakish belief (or fantasy) that every woman is at heart a rake collides with Richardson's deployment of the cult of true womanhood. But Richardson's novel has feet in both camps (or characters in both worlds); despite its wholehearted support of Clarissa's exemplarity, and the defeat through her of Lovelace's cynical system, suspicions about women's duplicity and lustfulness retain sufficient influence - have sufficient force - to impel Richardson to create secondary female characters who collectively represent all the stereotypical faults of women. (86)

In this respect, Gwilliam's argument is much like the one I make here.

${ }^{53}$ See Chesler, 69-75.

${ }^{54}$ Lovelace reiterates this same point over and again. See pages 535, 841, 906, and 935.

${ }^{55}$ In fact, Richardson notes the parallel in a footnote. In her analysis of the scene, Castle begins with a discussion of the ways in which Mrs. Sinclair's body is fragmented, broken like her leg. Her reading of Sinclair's death launches her discussion of the text's emphasis on the fragmentary nature of meaning and interpretation.

${ }^{56}$ See, for example, Defoe's "Some Considerations on Streetwalkers With a Proposal for lessening the present Number of them" (1726). Defoe's concern was less moral than economic, however. Recognizing that prostitutes are a "necessary evil," he called instead for their regulation by the state. For further discussion of Defoe's essay see Mudge, 53-55.

${ }^{57}$ Recently, much critical work has focused on both the eighteenth-century's anxiety about and reformation projects for prostitutes. See, for example, the essays of Joyce Grossman, Antony Simpson, and Jennie Batchelor. 
${ }^{58}$ For a brief discussion of the function of the dominatrix as a projection of male sadomasochistic fantasy in Clarissa, see Laura Hinton, "The Heroine's Subjection,” 299-304. Interestingly, Hinton argues that Clarissa acts as the dominatrix over Solmes; Hinton's focus on the heterosexual paradigm precludes an examination of the clearly dominatrix-like behavior of the prostitutes as they react against Clarissa's moral and class aggression.

59 The Sinclair household is clearly a more brazen version of Mrs. Jewkes from Richardson's first novel, Pamela, which Mudge examines. Mudge says Jewkes "serves both to dramatize Pamela's virtues and to highlight the disparity between 'good' femininity and 'bad' femininity" (192). She notes the scene in which Jewkes and Pamela wrestle in front of a peeping Mr. B; in this scene “they physically act out the novel's central conflict between 'good' and 'bad' femininity, between one definition of womanhood that celebrates women as the corporeal vessels of religious virtue and another definition that portrays them as the embodiments of satanic vice" (194). Pamela ultimately wins and wins over Mrs. Jewkes, who is reformed. Yet Mudge argues that Mr. B, as he gazes on, impotent to Mrs. Jewke s urgings that he not "dilly-dally," "sees his own conflict; he sees the beauty most desirable when unpossessed and the appetite that once satiated turns to abhorrence. Like Mrs. Jewkes, whose strong arms hold the struggling Pamela, the whore is the impassioned and fearful condition of possibility for the blushing maid" (194). Mudge continues,

The choice is impossible because neither can exist without the other; once the choice is made the fantasies self-destruct and allpowerful male is left along on the stage, staring forlornly at an empty bed. Pamela faints, in other words, to save Mr. B from destroying Richardson's fantasies: his fantasy of the chaste maiden; his fantasy of the moral novel; his fantasy of the unblemished middle-class marriage. (196)

Of course, in Pamela Mr. B cannot rape her when she faints; in Clarissa, Lovelace can. This problematizes Mudge's suggestion that Mr. B (and Richardson) do not want to cross that line because they might then have to choose between the two women. However, I argue that Clarissa's death satisfactorily relieves Richardson from having to confront this dilemma. Removed to ethereal presence, returned to her Father's house, his fantasy is left in-tact. ${ }^{60}$ See Eagleton, Castle, and Gardiner.

${ }^{61}$ See Janet Todd, The Sign of Angellica and Mary Poovey, The Proper Lady and the Woman Writer for a longer discussion of this dilemma and of the shifting map of women's writing as the century wore on. 
${ }^{62}$ For a brief but focused discussion of Clarissa-imitators, see Ruth Perry’s article, "Clarissa's Daughters...."

${ }^{63}$ One of these "misreadings" would be Linda Dunne's argument. In order to make the case that the women's "trials all involve the cruelty or weakness of men" (61), she must ignore stories involving women's complicity in male cruelty. She focuses on ways in which women aid each other, especially real or surrogate mothers. This skewing of the plot is most glaring when she blames Edward, not Lady Sheerness (a surrogate mother), for the tragic ending to the romance between Edward and Louisa.

${ }^{64}$ See Dorice Williams Elliott's argument for a discussion of how the novel feminizes a tradition of male-run philanthropic institutions. See also Johanna Smith, who argues in contrast that class hierarchy and patriarchal hegemony operate through feminized philanthropy.

${ }^{65}$ Nicole Pohl suggests that Scott would have had in mind Christine de Pizan's feminocentric utopia, The Book of the City of Ladies (1404/5). Pohl argues that this work, as well as countryhouse poems popular in the seventeenth-century, influenced the architectural representations of space and gender in the novel. Among the poets Pohl sees Scott most remniscent of are Amelia Lanyer and Katharine Philips. Pohl also suggests, as have others, that Scott is indebted to representations of feminine space in the works of Astell, Haywood, and Manley, in all of whose works "architectural space is re-appropriated...re-claimed and re-defined to the advantage and freedom of the separatist female community" (54-55).

${ }^{66}$ Donovan argues that the modern novel, defined by its allegiance to empiricism, realism, individualized characters, plain style text, and particularized time and space, originates in fifteenth century framed novellas written by women. That the novel is rooted in feminocentric concerns, and that the framed novella is the earliest form of the novel, seems obvious to Donovan. Donovan asserts that the novel emerged out of a history of casuistry, and is thus a subversive genre because, rather than laying down moral codes, it measures moral behavior by examining the particulars of the case. See also Martha J. Koehler, "Epistolary Closure and Triangular Return in Richardson's Clarissa," for a discussion of the ways in which Richardson uses the epistolary form to control his readers' interpretations of the characters and plot. ${ }^{67}$ See James Cruise for an analysis of the ways in which the women, Mrs. Maynard in particular, dominate interpretation.

${ }^{68}$ See my previous chapter. Also, see Armstrong, Desire and Domestic Fiction, for a discussion of the ways in which idealized femininity works to reform male desire. 
${ }^{69}$ Pierre Bourdieu, for example, argues that the logic of gift exchange works by disguising the relationship of obligation as "gift," in other words, to "prevent the economy from being grasped as an economy, that is, as a system governed by the laws of interested calculation, competition, or exploitation" (206). Gift exchange is simply another means by which individuals acquire symbolic power over others; that gift exchange implies a system of power, however, depends on the exchangers' failure to recognize it as such. One must leave behind "conscious intention." Jacque Derrida says similarly, "The gift must not appear or signify, consciously or unconsciously, as gift for the doners... [otherwise] it would be engaged in a symbolic, sacrificial, or economic structure that would annul the gift in the ritual circle of debt" (137). The donee, too, must "not recognize the gift as a gift"; to do so "suffices to annul the gift" (132). For further discussion of the economy of the gift, see Alan Schrift's collection of essays, The Logic of the Gift. ${ }^{70} \mathrm{I}$ am, of course, implicitly referencing arguments made famous by Luce Irigaray and Gayle Rubin.

${ }^{71}$ For an interesting, but quite different reading of Scott's revision of genre, see Betty Rizzo's discussion of Scott's appropriation of the gothic mode.

${ }^{72}$ Some have suggested that the anonymous work, The Histories of Some Penitents (1759), which predates Millenium Hall and tells the stories of women rescued by the Magdalen society, was actually written by Scott. See essays written by Mary Peace and Dorice Williams Elliott.

${ }^{73}$ Eve Tavor Bannet, interestingly, has lumped Sarah Scott in with other "Matriarchal Feminists," whose fictional versions of empowered women were often mocked by "Egalitarian Feminists" when they depicted matriarchal tyrants, women obsessed with their own power, in their own novels. Scott's resistance to such tyranny here seems to contradict Bannet's categorizing of her.

${ }^{74}$ Of course, Belford in Richardson's Clarissa famously remarks on the impossibility of women's friendships surviving marriage. See my previous chapter.

${ }^{75}$ For a discussion of women and property, and the inherent rivalries created between women by this system of exchange, see Gayle Rubin and Luce Irigaray.

${ }^{76}$ Haggerty, for example, argues that rather than victims, these women resist the conventional hystericization of their bodies. They "suffer, but they do not allow their suffering to seal their fates as victims of patriarchal narrative. In defiance of eighteenth-century medical 'wisdom,' they do not lose control: They simply become angry and defiant and learn to rely more exclusively on one another" (114).

${ }^{77}$ Additionally, Haggerty argues that Lady Melvyn is working to patrol hegemonic, heterosexual interests and that her schemes to marry off her stepdaughter evidence larger anxieties about the 
danger represented by the Sapphic friendship of Miss Melvyn and Louisa. In other words, when Miss Melvyn refuses to go to market, her stepmother forces her hand. The "bad" girl of this novel, then, is under the service of the patriarchal imperative.

${ }^{78}$ See Marianne Hirsch for a discussion of the ideological use of female orphans to deny women a maternal heritage.

${ }^{79}$ Many critics have made this connection, among them Felicity Nussbaum, Linda Dunne, and Dorice Elliot Williams.

${ }^{80}$ Linda Dunne, for example, sees the "monsters as representing those aspects of the ladies that are most unacceptable, most deviant, most vulnerable, and most oppressed by the dominant male culture.... [T] he monsters stand, in some sense, as metaphors of the sexuality of the ladies" (71).

${ }^{81}$ Sally O’Driscoll makes a similar argument about the women's “choice.” See pp. 70-71.

${ }^{82}$ Bannet's claim is in direct contrast to Lisa Moore, who argues that the women's mutual dependence on each other calls to mind Foucault's panopticon.

${ }^{83}$ As noted in earlier chapters, sociological studies have found evidence of greater direct aggression among women of working-classes. While female competition may be just as present in relationships among women from all classes, it seems most visible among women who are impoverished, perhaps because the stakes for these women are much higher, or because of cultural differences which subject women of middle and upper classes to more stringent codes of propriety. See Phyllis Chesler for an overview of these studies.

${ }^{84}$ See Lillian Faderman's discussion of the conditions of idealized romantic friendship, pp. 103106.

${ }^{85}$ See Lisa Moore, p. 44. Moore argues further that the metaphor of slavery is overused and, finally, treated as an empty signifier. Moreover, the women of Millenium Hall repeatedly insist that slavery is a condition of the mind, and that one can even volunteer to be a slave; in doing so, they implicitly justify the actions of those who claimed to be "good" slaveowners.

${ }^{86}$ Many critics have noted Scott's maintenance of class hierarchy, including Janet Todd, Lisa Moore, Eve Tavor Bannet, and Bradford K. Mudge. Mudge, for example, argues that in order for the community to work, the women within it must disown passion. Thus, "sexuality is displaced downward to working-class women that the Hall first trains and then marries off. If the problem is passion, the answer is management" (217).

${ }^{87}$ Nearly every critic cited here discusses the women's need to denounce their sexuality. A few critics, however, like George Haggerty and Lisa Moore, both conducting homoerotic readings of 
the women's relationships, have argued that the women do not resist female sexuality but reform the terms by which it is understood and the conditions under which it is expressed.

${ }^{88}$ A similar argument is made by Felicity Nussbaum, who argues that the domesticated feminine space of Millenium Hall, like other "feminotopias," provides a refuge from and clear contrast to male, colonizing desire. Nussbaum has also argued that the maternal relationships between the women, stripping them of sexuality, also provides a "safe" alternative to Sapphic communities (164). The women's escape from sexuality, explains Nussbaum, is made possible by redefining beauty as "monstrous" and physical deformity as "valuable."

${ }^{89}$ Kristina Straub, for instance, argues that this scene exposes "rules that legitimize [the old women's] neglect and abuse" and is "analogous to the entertainment provided by foolish old women throughout eighteenth-century literature" (44). She says further, "this contrived game reflects and emphasizes the less overt violence inflicted on their younger counterparts in the social game-playing that more subtly victimizes young women" (46). Audrey Bilger also analyzes this scene, arguing that "Burney takes the jokes against women out of the hands of misogynist satirists and robs them of their easy targets. Her violent comedy has built in feminist critique. If we find it painfully humorous, we are one step closer to understanding her anger at and defiance of the brutal treatment of women when we recognize our own complicity" (216217).

${ }^{90}$ Margaret Doody, for example, suggests of Burney's treatment of Madam Duvall, "Burney points out that women's hatred of other women is useful to the most antipathetic concerns and desires of males" (55). Yet Doody does not fully explore the implications of Burney's disclosure-a study this paper seeks to develop.

${ }^{91}$ Not uncommon, such wills generally worked to the advantage of families with large dowries for their daughters, especially if suitors had little money and were willing to give up their last names or if the suitors had money, but no direct access to a title. The Delviles, however, have both money and title, therefore Cecilia's value is only measurable within the meritocracy Burney advocates.

${ }^{92}$ See also D. Grant Campbell's essay which explores Burney's critique of the problematics of a credit-based society.

${ }^{93}$ Nevertheless, Burney was quick to defend her depiction of Briggs and Delvile. In a letter to her sister, Susanna Philips, she recorded the conversation between two women who claimed to have met real people exactly like the two men. See Burney, Journals and Letters, Letter 93, p.201-02. 
${ }^{94}$ See Katharine Sobba Green's discussion of Burney's response to and revision of the marketplace blazon in her chapter devoted to Cecilia.

${ }^{95}$ Much critical work has examined the ideological work performed by female rivalry in romance. See for example Helena Michie's Sororophobia and Devoney Looser's essay, "Scolding Lady Mary Wortley Montagu? The Problematics of Sisterhood in Feminist Criticism.” For a modern perspective on this theme, see Susan Ostrov Weisser, "The Wonderful-Terrible Bitch Figure in Harlequin Novels."

${ }^{96}$ For further discussion of the inextricable link between gender and class ideologies, see Leonore Davidoff's and Katherine Hall's classic study, Family Fortunes.

${ }^{97}$ For example, Jane Spencer suggests that although Evelina possesses a certain "vitality," the works that follow demonstrate a "timidity" owing to Burney's fear of her father's disapproval (98). Todd, too, suggests that Burney's works represent "internalized [male] parental authority transmuted into a female author" (Sign 277). For a related argument about women writer's desire for paternal affirmation, see Elizabeth Kowaleski-Wallace, Their Father's Daughters.

${ }^{98}$ Avoiding an anachronism, I use the term "feminist" in the way that Audrey Bilger employs it: as a "guiding principle" in the eighteenth century, rather than a recognized ideological platform (10).

${ }^{99}$ Says psychologist Laura Tracy, "Because we have been forced to separate our aggressive and erotic desires in relation to men, we locate our aggression in our relations with other women" (qtd. in Chesler 155).

${ }^{100}$ My argument here is indebted to both Irigaray's and Rubin's influential studies of women's commodification and exchange.

${ }^{101}$ See Girard's discussion of masochism and sadism.

${ }^{102}$ Much has been said about not only Mortimer's impotence as a male hero, but the inadequacy of the other male characters in the novel. For analysis of the ways in which these characters can be read as feminist resistance, see Kristina Straub's chapter "Love and Work," in Divided Fictions, Bilger's chapter, "Mocking the 'Lords of Creation': Male Comic Characters," in Laughing Feminism, and Kay Rogers, "Deflation of Male Pretensions in Fanny Burney's Cecilia." ${ }^{103}$ See Lisa L. Moore and Elizabeth Susan Wahl for extended discussions of representations of female homoerotic desire in eighteenth-century narratives.

${ }^{104}$ The subject of mother-daughter bonds and a lost maternal economy have been extensively theorized. My work here is perhaps most influenced by the work of Irigaray, Nancy Chodorow, Marianne Hirsch, and Jean-Joseph Goux, and specific to eighteenth-century criticism, Susan 
Greenfield. However, my argument here most closely resembles Lisa Moore's. Moore argues that "late eighteenth- and early nineteenth-century discourse of romantic friendship gives priority to the ideological work of sexuality as a social category related to but distinct from the operations of gender" (10).

${ }^{105}$ One could argue that the threat of heterosexual incest posed by Mrs. Delvile's over-investment in her son is displaced onto homosexual incest. Susan Greenfield notes a very similar narrative strategy in Radcliffe's The Italian, in which she says "Ellena and Olivia's [mother-daughter] bond emerges as a conservative force, a form of erotic connection distinguished for its comparatively limited capacity to disturb [the heterosexual matrix]" (Mothering 74). In other words, Radcliffe relies on masculinist assumptions about female sexual passivity to posit intense female friendships as an alternative to compulsory heterosexuality and the overdetermined female rivalries of the romance plot.

${ }^{106}$ Journals and Letters, 13 March 1782.

${ }^{107}$ Chesler explains,

Women long for intimacy with other women, but fear that a female intimate is also, potentially, a betrayer. Only she can poison people's minds about you. She has been by your side; you two have been an "item." If she says something about you, your mutual friends might think it is true....This longing for female intimacy coupled with a fear of female betrayal might explain why so many adult women remain so "girlishly" reluctant to disagree with or confront a female intimate outright, directly, with any unpleasant truths, such as: I envy you; I disapprove of you; I am threatened by you.... (317)

${ }^{108}$ See Hemlow, Chapter Two, pages 35-40.

${ }^{109}$ See Marilyn Butler, A Literary Biography.

${ }^{110}$ In The Sign of Angellica, Todd charts the transformation of femininity from the restoration through to the late eighteenth-century as it is negotiated by women writers.

${ }^{111}$ See Armstrong's classic study, Desire and Domestic Fiction for a discussion of the rise of the figure of domestic woman in eighteenth-century conduct-book literature. Because the recommendation for reform takes place within the domestic framework, supposedly an apoliticized space, the figure of woman works subtly and strategically to transform political information into a gendered psychological condition. According to Armstrong, the "knowledge" 
that domestic fiction works to disseminate in the eighteenth and early nineteenth centuries is that which defines and supports morality as imbued with middle-class values. It establishes the connection between virtue and class primarily through the figure of domestic woman.

${ }^{112}$ See Luce Irigaray, "Women on the Market" and Gayle Rubin, "The Traffic in Women" for further discussion of women's commodification within a market economy and their resulting vexed relationships with each other.

${ }^{113}$ Elizabeth Kowaleski-Wallace, for example, argues that Maria Edgeworth, because so dependent on her father's approval practices self-effacement: "Privileging his voice in her texts, time and again, she speaks for him and through him to argue for the benevolent effects of patriarchal training" (97). Kowaleski-Wallace excuses Edgeworth's complicity, noting that identification with the Father and investment in the ideology of rational woman was her only viable access to agency and self-definition. Yet she suggests that " $[\mathrm{t}] \mathrm{o}$ work within a patriarchal model, to make claims for women in response to an agenda already set by the fathers, is necessarily never to question how the issues were defined in the first place" (108). I disagree that Edgeworth never raises such questions; indeed, as this chapter will show, her rhetoric, laced with self-reflexivity, consistently doubles back on itself to question a performative complicity. ${ }^{114}$ See my chapter on Cecilia, indebted to Kristina Straub's discussion of evidence of Burney's psychic trauma, a result of her contradictory position as woman and woman writer.

${ }^{115}$ And, of course, because he has discovered that she has already repaid Clarence, who lent the money to Lady Delacour, out of her own inheritance.

${ }^{116}$ Bannet's work, which divides Enlightenment feminisms into two camps, matriarchs and egalitarians, examines the different ways in which these two sects use both positive and negative exempla to challenge and revise the others' strategies. Both work to prescribe a new notion of femininity and conceptualize the notion of separate spheres not yet in practice.

${ }^{117}$ Thompson explains that the decisive break between private and public spheres is an effect of this crisis in value, borne out of a need to articulate a notion of value not subject to the instabilities of the market.

${ }^{118}$ See my introduction for an extended discussion of these historical tensions.

${ }^{119}$ See for example Nicholas Mason who, relying heavily on Nancy Armstrong's Desire and Domestic Fiction, articulates a very convincing argument about the link between gender and class in Belinda. Mason makes the provocative claim that "the middle-class does not monopolize the role of the exemplar in the narrative" (281). See also Jordana Rosenberg's work. 
${ }^{120}$ The notion that the middle-class rose in the eighteenth-century, as posited by Ian Watt in The Rise of the Novel, has been largely contested by those that have argued the eighteenth-century novel, rather than rising as a result of an emerging middle-class, actually prescribes behaviors not yet practiced (see my Introduction). Here I do not assume that the families of domestic fiction are of a middle-class income - in fact, many are from the landed class; however, they adopt middleclass behaviors, as in the example of the Percival family. Says Armstrong, "Domestic order is not based on one's relative socioeconomic status so much as on moral qualities of mind" (Desire 130). For further discussion of the rise of the middle-class and middle-class behaviors, see Leonore Davidoff and Katherine Hall's classic study, Family Fortunes.

${ }^{121}$ Of course, one might argue that his ejection is really a form of scapegoat and bound up in the threat of miscegenation and anxieties about catholic contamination.

122 See, for example, dissertational works by Jessica Anne Richard and Hope Donovan Cotton, as well as Gillian Russell's essay, “Faro's Daughters: Female Gamesters, Politics, and the Discourse of Finance in 1790's Britain."

${ }^{123}$ Felicity Nussbaum's The Brink of All We Hate is a good source for discussion of masculinist satires of women's bodies. Also see Laura Brown's Women and Empire for a discussion of the ways in which the stripping of women's bodies to arrive at some ideological truth works to displace tensions about commodity fetishism and aristocratic excess, while also allegorizing the eighteenth-century mystification of value and the epistemological struggle between sign and signified.

${ }^{124}$ Green does not refer to Belinda's commodification, but to Richardson's Harriet Byron in Sir Charles Grandison. My entire argument is heavily indebted to Green's discussion of the commodification of women and women writers' parodic depictions of the marketplace blazon. See Chapter Three in The Courtship Novel for her discussion of the ways in which women writers revise the blazon to contest the "rakish consumerism" of their bodies.

${ }^{125}$ Edgeworth implicitly criticizes the well-known marketing strategies of Packwood's razorsnoting that the owners of the company don't write their own advertisements, but pay someone else to do so. The notion that someone else might profit economically from praising someone else's creation seems to the character in Ennui disingenuous. Significantly, this anecdote is told to corroborate another character's complaint about the enlisting of poets by aristocrats to produce self-aggrandizing translations-advertisements, if you will, of their own virtues.

${ }^{126}$ Kowaleski-Wallace, in particular, writes, "Freke is never more than an amusing caricature, the comic embodiment of a series of crude, unmediated female energies" and that Edgeworth's 
"discrediting of radical philosophy is another essential step in the implementation of a domestic ideology that demands the repression of competing modes of life" (174). Kowaleski-Wallace claims that deviant characters like Harriet Freke and the initial sketch of Lady Delacour work to contain the threat of aberrant female sexuality and thereby to exclude competing modes of desire other than that legitimated by patriarchal ideology. Indeed, as Kirkpatrick makes clear in her introduction to the novel, Freke was an addition to a subsequent sketch of the novel, onto which Lady Delacour's own "freakish aspects were later transferred" (xix). However, I am skeptical of analyses that say any character works only as a site of containment; instead, I posit that negative exempla can work vicariously to voice the author's resistance to patriarchy. ${ }^{127}$ The fictional Hervey's misogynistic scheme to create a perfect wife in Virginia St. Pierre is clearly an indictment of Rousseau's real life attempts to do the same.

${ }^{128}$ Some critics have discussed the parallels between Wollstonecraft and Edgeworth. Eve Tavor Bannet, while positioning Edgeworth as a Matriarchal Feminist and Wollstonecraft as an Egalitarian, nevertheless argues that the two are often in dialectical, rather than oppositional relationship. Anne Mellor, too, draws connections between the educational reform advocated by both Wollstonecraft and Edgeworth, as does Kathryn Kirkpatrick in her introduction to Belinda. ${ }^{129}$ The "man-trap" in which Freke's foot is caught is generally read as her punishment for gender transgressions or as a way of confining competing versions of femininity. Additionally, I suggest that we can read it within the context of the correlated binaries man/woman, public/private; in other words, the "man-trap" is also the "public-trap" from which the private sphere should be safe. Harriet Freke's public behaviors expose not just herself, but the domestic sphere to marketplace/masculine dangers. Belinda's moral behavior avoids these "man-traps." ${ }^{130}$ For a discussion of the ideology of women's reading habits, see Jacqueline Pearson, Women's Reading in Britain, 1750-1835.

131 Throughout Mrs. Stanhope's nieces are referred to as her "pupils" or "students" whom she has "documented" to look only towards marrying upward.

${ }^{132}$ As noted in an earlier footnote, Hervey attempts the romantic system for educating women described by Rousseau and employed in Jacques Henri Benardin de Saint-Pierre's novel, Paul et Virginia .

${ }^{133}$ For a longer discussion of the women's commodification and exchange of Vincent, see my article, “'The Remote Cause of My Love': Female Rivalry and Miscegenation in Edgeworth's Belinda," currently under review for publication. 
${ }^{134}$ See, for example, Susan Lanser, "Befriending the Body: Female Intimacies as Class Acts." Lanser posits, "By the 1740's, female friendship has ceased to be the property primarily of female pens and...keeping female bonds under control had become a hegemonic interest..." (187). For further discussion of the depiction of female friendship and rivalries in eighteenth-century literature, see my Introduction.

${ }^{135}$ Harriet Freke has played a joke on Vincent's servant, Juba, which results in their both leaving Harrowgate.

136“The Harrowing of Hell” is an old or middle-English term for Christ's descent to Hell. Employed throughout $13^{\text {th }}$ and $14^{\text {th }}$ century literature in dramatic dialogue in verse (or miracle plays), it was brought to England from France and translated in the eighteenth-century. "The Harrowing of Hell" has also been rendered in European iconography dating back to $13^{\text {th }}$ or $14^{\text {th }}$ centuries.

${ }^{137}$ See my Introduction.

${ }^{138}$ See Kathryn Kirkpatrick, "The Limits of Liberal Feminism in Maria Edgeworth's Belinda." ${ }^{139}$ Phyllis Chesler explains that belonging is more important to women than men because whereas men are taught to aim for independent status recognition, women are told to avoid such isolation. Instead, they are socialized to search for recognition within groups of other women, and that exclusion from these groups can "amount to a loss of one's own existential footing" (83). ${ }^{140}$ Eagleton does not comment on Carters' assumptions about female rivalry.

${ }^{141}$ According to the OED, the first use of the word "catty" to describe a sly or spiteful character (always in reference to women), is in 1886: "there is a sly, catty look about her." There is an earlier 1883 reference to cattish behavior in the same sense. The next reference is to an article in the Westminster Gazette 11 Dec. 1909: "A noted prelate...said recently in addressing a community composed of the fair sex that all such communities had the temptation to be "catty."” ${ }^{142}$ While Todd argues that Behn profits from rumors about her personal life because of the public's inability to separate author and sign (Sign), Catherine Gallagher disagrees, claiming that Behn capitalized on using a sexually transgressive authorial personae which audiences were able to distinguish from Behn. What is important here, however, is that the racy social climate of the Restoration made room for an immodest femininity_room not available in the decades to come. ${ }^{143}$ See Spencer's extended discussion on the public construction of the opposition between Orinda and Astrea. See also Todd, The Sign of Angellica, Chapter 2.

${ }^{144}$ In The Sign of Angellica, Todd also argues that Manley was able to bridge the differences between Behn and Phillips (41). 
${ }^{145}$ Importantly, Manley is not always recognized as a proper woman writer. In fact, she is often contrasted to women writers who lead more chaste lives and whose writings present a paradigm for moral living. Ironically, she is more often lumped in on the Astrea-side of the binary. Samuel Richardson, for example, aligns Behn, Manley, and Haywood and calls on women writers of his generation to provide "the Antidote to these Women's Poison" (qtd. in Todd, Sign 131).

${ }^{146}$ Significantly, More was also involved in another highly publicized feud with poet Hannah Cowley, also apparently struggling financially until "discovered” by playwright Garrick. In 1799, Cowley accused More of plagiarizing her tragedy Albina. But Cowley, like Yearsley, learned the consequences of going up against such a powerful female literary figure and lost much support from polite literary society. Eighteenth-century writer and socialite, Hester Thrale Piozzi, said of Cowley, "She and I never met; I fancy her Vulgar \& ill behav'd." (qtd. in Lonsdale 385). Piozzi also said of one of Cowley's epilogues: "one might write such Stuff in one's Sleep" (qtd. in Lonsdale 386). Piozzi, like More, used her social clout to emphasize the class differences between herself and another, claiming an implicit moral and intellectual superiority.

${ }^{147}$ Stephen Duck was a lower-class poet raised from obscurity to brief fame through the patronage of Queen Caroline.

${ }^{148}$ Lactilla is Yearsley's pseudonym. The excerpt is from Horace Walpole, "Letter to Hannah More, Strawberry Hill, 4 November 1789."

${ }^{149}$ Although the poem was not published until 1825, it would have certainly traveled in the circles of her famous literary acquaintances, Elizabeth Montagu, Hester Chapone, and Hannah More. ${ }^{150}$ Chesler quotes an African-American scholar who experienced this while on the job market (340-41).

${ }^{151}$ Naomi Wolf's Misconceptions is a wonderful, much needed analysis and scathing indictment of our culture's misogynistic attitudes toward mothers and mothering. She argues that there is no social structure in place to support the needs of pregnant women and mothers who instead face a "social demotion" which associates motherhood, ironically, with valuelessness. See also Judith Warner's recent article, "Mommy Madness," in which in addition to considering some of the reasons why women feel compelled to play "superwoman," she also closes with concrete suggestions for ways in which our society and government might work together to ease the plight of working parents. A quite different analysis of the subject by Reva Landau, author of "On 'Making Choices,"' suggests that women should not leave the work-force to become full-time 
homemakers, and to do so is a triumph for patriarchy. She, too, offers tangible strategies for ways in which women might stay in the work-force without feeling guilty.

${ }^{152}$ Both Leora Tannenbaum and Phyllis Chesler, each with chapters focusing on aggression between women in the workplace, address the resentment women who choose the "mommy track" feel towards and from other women.

${ }^{153}$ An excellent example of a proposal for how different kinds of feminists might work together can be found in Linda C. McClain's essay, "Equality, Oppression, and Abortion: Women Who Oppose Abortion Rights in the Name of Feminism." McClain addresses the arguments made by women who, while pro-life, claim to be feminists. Rather than denying their identificatory claim, McClain argues that activists on both sides should seek out their common ground and, in doing so, work together against the conditions of women's oppression.

${ }^{154}$ According to recent studies, more women are choosing to stay home, either part-time or fulltime. Reports a March 2004 article in Time:

What some experts are zeroing in on is the first-ever drop-off in workplace participation by married mothers with a child less than 1 year old. That figure fell from 59\% in 1997 to $53 \%$ in 2000. The drop may sound modest, but, says Howard Hayghe, an economist at the Bureau of Labor Statistics, 'that's huge,' and the figure was roughly the same in 2002. Significantly, the drop was mostly among women who were white, over 30 and well educated.

Further, "Census data reveal an uptick in stay-at-home moms who hold graduate or professional degrees--the very women who seemed destined to blast through the glass ceiling. Now $22 \%$ of them are home with their kids. A study by Catalyst found that 1 in 3 women with M.B.A.s are not working full-time (it's 1 in 20 for their male peers)."

${ }^{155}$ An excellent example of the way in which housewives feel threatened by feminist ideology is Carolyn F. Graglia's article, "The Housewife as Pariah," in which the author responds to what she sees as attacks against housewives by “popular” feminists like Betty Friedan, Gloria Steinham, and Hilary Rodham Clinton. She cites from Friedan's Feminist Mystique in which the author indict[s] the housewife's life as a "waste of a human self," lived without using adult capabilities or intelligence[.] Friedan analogized these "parasites" to "schizophrenics" and "male patients with portions of their brain shot away." "There is 
something less than fully human," she continues, "in those who have never known a commitment to an idea," or "risked an exploration of the unknown," or "attempted the kind of creativity of which men and women are potentially capable."

What matters less for my analysis is how accurate her reading of Friedan (or any of the other cited 'feminists') is, but the fact that she perceives herself as under fire because of her choice to stay home. See also Lesley Johnson, who looks at the impact of second-wave feminism on the figure of the housewife in "'Revolutions Are Not Made by Down-trodden Housewives':

Feminism and the Housewife."

${ }^{156}$ Jennifer Baumgardiner's and Amy Richards' Manifesta: Young Women, Feminism and the Future is one example of a book that tries to bring together the vexed history of feminism, to consider its changing objectives and to suggest where we might go together, as a society. Very wittily and honestly written, it avoids the pretentious tone of much academic discourse, and, in doing so, attempts to collapse some of the boundaries between female academics and "mainstream" women. 
Works Cited

Alcoff, Linda. “The Problem of Speaking for Others.” Feminist Nightmares, Women at Odds: Feminism and the Problem of Sisterhood. New York: New York UP, 1994. 285-309.

Allestree, Richard. The Whole Duty of Man. London, 1751.

Armstrong, Nancy. Desire and Domestic Fiction: A Political History of the Novel. New York: New York UP, 1987.

--- "Reclassifying Clarissa: Fiction and the Making of the Modern Middle Class." Clarissa and Her Readers: New Essays for the Clarissa Project. Eds. Carol Houlihan Flynn and Edward Copeland. New York: AMS, 1999. 19-43.

Aughterson, Kate. Renaissance Women: Constructions of Femininity in England. London: Routledge, 1995.

Backscheider, Paula. “The Novel's Gendered Space.” Revising Women: Eighteenth Century “Women's Fiction” and Social Engagement. Ed. Paula Backscheider. Baltimore: Johns Hopkins UP, 2001. 1-30.

Ballaster, Ros. Seductive Forms: Women's Amatory Fiction from 1684-1740. Oxford: Clarendon, 1992.

Bannet, Eve Tavor. The Domestic Revolution: Enlightenment Feminisms and the Novel. Baltimore: Johns Hopkins UP, 2000.

Barbauld, Anna. "The Rights of Woman." Eighteenth Century Women Poets. Ed. Roger Lonsdale. Oxford: Oxford UP, 1989.

Baskan, Judith R. "Women at Odds: Biblical Paradigms." Feminist Nightmares, Women at Odds: Feminism and the Problem of Sisterhood. New York: New York UP, 1994. 209-24.

Batchelor, Jennie. 'Industry in Distress': Reconfiguring Femininity and Labor in the Magdalen House.” Eighteenth-Century Life 28.1 (2004): 1-20.

Bean, Brenda. "Sight and Self-disclosure: Richardson's Revision of Swift's 'The Lady's Dressing Room."” Eighteenth-Century Life 14.1 (1990): 1-23. 
Beasley, Jerry C. "Clarissa and Early Female Fiction.” Clarissa and Her Readers: New Essays for the Clarissa Project. Eds. Carol Houlihan Flynn and Edward Copeland. New York: AMS Press, 1999. 69-96.

Bechler, Rosemary. "Reading the Fire-Scene in Clarissa." Samuel Richardson. Ed. Harold Bloom. New York: Chelsea House, 1987. 141-60.

Benedict, Barbara M. "Reading Faces: Physiognomy and Epistemology in Late Eighteenth-Century Sentimental Novels.” Studies in Philology 92 (1995): 311-28.

Bilger, Audrey. Laughing Feminism: Subversive Comedy in Frances Burney, Maria Edgeworth, and Jane Austen. Detroit: Wayne State UP, 1998.

Bloom, Harold, ed. "Richardson as Novelist: Clarissa." Samuel Richardson. New York: Chelsea House, 1987. 7-32.

Borin, Francois. "Judging by Images." A History of Women: Renaissance and Enlightement Paradoxes. Cambridge: Belknap Press of Harvard UP: 1993.

Bourdieu, Pierre. "Selections from The Logic of Practice." The Logic of the Gift: Toward an Ethic of Generosity. Ed. Alan B. Schrift. New York: Routledge, 1997.

Brody, Miriam. "Introduction." A Vindication of the Rights of Woman. 1792. Ed. Miriam Brody. New York: Penguin, 1992.

Brown, Kathleen M. “'A P[ar]cell of Murdereing Bitches': Female Relationships in Eighteenth-Century Slaveholding Households." Maids and Mistresses, Cousins and Queens: Women's Alliances in Early Modern England. Eds. Susan Frye and Karen Robertson. Oxford: Oxford UP, 1999. 87-97.

Brown, Laura. Ends of Empire: Women and Ideology in Early Eighteenth-Century English Literature. Ithaca: Cornell UP, 1993.

Burney, Frances. Cecilia. 1782. Eds. Peter Sabor and Margaret Anne Doody. Oxford: Oxford UP, 1988.

---. Evelina. 1778. Ed. Margaret Anne Doody. London: Penguin, 1994.

---. Journals and Letters. Eds. Peter Sabor and Lars E. Troide. New York: Penguin, 2001.

---. Selected Letters and Journals. Ed. Joyce Hemlow. Oxford: Oxford UP, 1986. 
Butler, Judith. Bodies that Matter: On the Discursive Limits of "Sex." New York: Routledge, 1993.

Butler, Marilyn. Maria Edgeworth: A Literary Biography. Oxford: Oxford UP, 1972.

Campbell, D. Grant. "Fashionable Suicide: Conspicuous Consumption and the Collapse of Credit in Frances Burney's Cecilia." Studies in Eighteenth-Century Culture 20 (1990): 131-45.

Castle, Terry. Clarissa's Ciphers: Meaning and Disruption in Richardson's “Clarissa." Ithaca: Cornell UP, 1982.

Chambers, Ross. "Narrative and Other Triangles." The Journal of Narrative Technique 19 (1989): 31-48.

Chudleigh, Lady Mary. “The Ladies’ Defence." 1701. Eighteenth Century Women Poets. Ed. Robert Lonsdale. Oxford: Oxford UP, 1989.

---. "To the Ladies." 1703. Eighteenth Century Women Poets. Ed. Robert Lonsdale. Oxford: Oxford UP, 1989.

Cixous, Helene. "Sorties: Out and Out." The Logic of the Gift: Toward an Ethics of Generosity. Ed. Alan B. Schrift. New York: Routledge, 1997.

Cotton, Hope Donovan. Woman and Risk: The Gambling Women in Eighteenth-Century England. Dissertation Abstracts International, Section A: The Humanities and Social Sciences 59.5 (1998): 1581+.

Cruise, James. “A House Divided: Sarah Scott's Millenium Hall.” Studies in English Literature, 1500-1900 35.3 (1995): 555-73.

Davidoff, Leonore, and Katherine Hall. Fortunes: Men and Women of the English Middle Class 1780-1850. 2nd ed. Routledge: London, 1992.

Demaria, Robert, ed. British Literature, 1640-1789: An Anthology. Oxford: Blackwell, 1996.

Derrida, Jacque. "The Time of the King." The Logic of the Gift: Toward an Ethic of Generosity. Ed. Alan B. Schrift. New York: Routledge, 1997.

Donovan, Josephine. Women and the Rise of the Novel, 1405-1726. New York: St. Martin's, 1999.

Doody, Margaret Ann. Frances Burney: The Life in the Works. New Brunswick: Rutgers UP, 1988. 
Doody, Margaret Anne, and Florian Stuber. “Clarissa Censored.” Modern Language Quarterly Winter 1998: 74-88.

Dryden, John. The Rival Ladies. London : Printed by W.W. for Henry Heringman, 1664.

Dunne, Linda. "Mothers and Monsters in Sarah Robinson Scott's Millenium Hall." Utopian Science Fiction by Women. Eds. Jane L. Donawerth and Carol A. Kolmerten. Syracuse:Syracuse UP, 1994.

Eagleton, Terry. The Rape of Clarissa: Writing, Sexuality, and Class Struggle in Samuel Richardson. Minneapolis: U of Minnesota P, 1982.

Edgeworth, Maria. Belinda. Introd. Kathryn Kirkpatrick. Oxford: Oxford UP, 1994.

---. Castle Rackrent and Ennui. Introd. Marilyn Butler. London: Penguin, 1992. Ennui. 1809.

---. Letters for Literary Ladies, to which is added an Essay on the Noble Science of Self Justification. London, 1795.

Edgeworth, Maria, and Robert Lovell Edgeworth. Practical Education. London, 1798. Eger, Elizabeth. "Representing Culture: 'The Nine Living Muses." Women, Writing and the Public Sphere, 1700-1830. Cambridge: Cambridge UP, 2001. 104-32.

Elliott, Dorice Williams. "Sarah Scott's Millenium Hall and Female Philanthropy." Studies in English Language, 1500-1900 35.3 (1995): 535-53.

Faderman, Lillian. Surpassing the Love of Men: Romantic Friendship and Love Between Women from the Renaissance to the Present. New York: Perennial, 1981.

Fleetwood, William. The Relative Duties of Parents and Children, Husbands and Wives, Masters and Servants. London: Printed for John Hooke, 1716.

Frye, Susan, and Karen Robertson. Maids and Mistresses, Cousins and Queens: Women's Alliances in Early Modern Literature. Oxford: Oxford UP, 1991. Gallagher, Nobody's Story: Women Writers in the Marketplace 1670-1820. Berkeley: Berkeley UP, 1994.

Gardiner, Ellen. Regulating Readers: Gender and Literary Criticism in the EighteenthCentury Novel. Newark: U of Delaware P, 1999.

Gisborne, Thomas. Enquiry into the Duties of the Female Sex. London: Printed for T. Cadell Jun. and W. Davies, 1797. 
Gould, Robert. The Rival Sisters, or, The Violence of Love. London : Printed for Richard Bentley, 1696.

Goux, Jean-Joseph. Symbolic Economies: After Marx and Freud. Trans. Jennifer Curtiss Gage. Ithaca: Cornell UP, 1990.

Graglia, Carolyn F. “The Housewife as Pariah.” Harvard Journal of Law \& Public Policy 18.2 (1995): 509-523. MLA Bibliography. Ebscohost. West Virginia University Library, Morgantown. 22 Feb. 2005. $<$ http://search.epnet.com/login.aspx?direct=true \&db=afh\&an=951030511>.

Greenfield, Susan. “'Abroad and at Home': Sexual Ambiguity, Miscegenation, and Colonial Boundaries in Edgeworth's Belinda." PMLA 112 (1997): 214-28.

---. Mothering Daughters: Novels and the Politics of Family Romance, Frances Burney to Jane Austen. Detroit: Wayne State UP, 2002.

Grossman, Joyce. 'Sympathetic Visibility,' Social Reform and the English Woman Writer: The Histories of Some of the Penitents in the Magdalen-House." Women's Writing 7.2 (2000): 247-66.

Gwilliam, Tassie. Samuel Richardson's Fictions of Gender. Stanford: Stanford UP, 1993.

Habermas, Jurgen. The Structural Transformation of the Public Sphere. Cambridge: MIT, 1999.

Haggerty, George. "Romantic Friendship" and Patriarchal Narrative in Sarah Scott's Millenium Hall." Genders 13 (1992): 108-22.

---. Unnatural Affections: Women and Fiction in the Later Eighteenth Century. Bloomington: Indiana UP, 1998.

Halifax, George. The Lady's New-years Gift, or Advice to a Daughter. London: Printed for Matt Gillyflower and James Partridge, 1688.

Hawkins, Laetitia Matilda. Letters on the Female Mind. London, 1793.

Hays, Mary. Appeal to the Men of Great Britain in Behalf of Women. London: Printed for J. Johnson and J. Bell, 1798

Hemlow, Joyce. Fanny Burney. Oxford: Oxford UP, 1958.

Hinton, Laura. "The Heroine's Subjection: Clarissa, Sadomasochism, and Natural Law." Eighteenth-Century Studies 32 (1998): 293-308. 
Hirsch, Marianne. The Mother/Daughter Plot: Narrative, Psychoanalysis, Feminism. Bloomington: Indiana UP, 1989.

Hunter, J. Paul. Before Novels: The Cultural Contexts of Eighteenth-Century English Fiction. New York: W. W. Norton, 1990.

Irigaray, Luce. This Sex Which is Not One. Ithaca: Cornell UP, 1985.

Jennings, Marianne. “Whose Harrassing Whom?” Wall Street Journal 6 July 1999: A14.

Johnson, Lesley. “'Revolutions are Not Made by Down-trodden Housewives': Feminism and the Housewife." Australian Feminist Studies 15.32 (2000): 237249.

Jones, Ann Rosalind. "Maidservants of London: Sisterhoods of Kinship and Labor." Maids and Mistresses, Cousins and Queens: Women's Alliances in Early Modern Literature. Eds. Susan Frye and Karen Robertson. Oxford: Oxford UP, 1991. 2132.

Jones, Robert W. "Obedient Faces: The Virtue of Deformity in Sarah Scott's Fiction." Defects: The Engendering of the Modern Body. Eds. Helen Deutsch and Felicity Nussbaum. Ann Arbor: U of Michigan P, 2000. 280-302.

Keller, Evelyn Fox, and Helene Moglen. "Competition: A Problem for Academic Women." Competition: A Feminist Taboo? New York: The Feminist Press, 1987. 21-37.

Kelly, Gary. "Bluestocking Feminism." Women, Writing and the Public Sphere, 17001830. Cambridge: Cambridge UP, 2001. 163-80.

Kinkead-Weekes, Mark. "The Inquisition (The Final Installment)." Samuel Richardson. Ed. Harold Bloom. New York: Chelsea House, 1987. 69-86.

Kirkpatrick, Kathryn. "The Limits of Liberal Feminism in Maria Edgeworth's Belinda." Jane Austen and Mary Shelley and Their Sisters. Ed. Laura Dabundo. New York: UP of America, 2000: 73-82.

Kittredge, Katharine. "Men-Women and Womanish Men: Androgyny in Richardson's Clarissa." Modern Language Studies 24.2 (1994): 20-26.

Knights, Elspeth. "'Daring but to Touch the Hem of her Garment': Women Reading Clarissa." Women's Writing 7.2 (2000): 221-45. 
Koehler, Martha J. "Epistolary Closure and Triangular Return in Richardson's Clarissa." The Journal of Narrative Technique. 24.3 (1994): 153-72.

Kowaleski-Wallace, Elizabeth. Their Fathers' Daughters: Hannah More, Maria Edgeworth and Patriarchal Complicity. Oxford: Oxford UP, 1991.

Landau, Reva. “On 'Making Choices.” Feminist Issues 12. 2 (1992): 47-73.

Lanser, Susan Sneider. "Befriending the Body: Female Intimacies as Class Acts." Eighteenth Century Studies 32.2 (1998-99): 179-98.

Landry, Donna. "Manley, Delarivier.” Dictionary of Literary Biography. Ed. Donald Seibert. Detroit: Gale Research, 1991.

Laquer, Thomas. Making Sex: Body and Gender from Greeks to Freud. Cambridge: Harvard UP, 1992.

Lee, Nathaniel . The Rival Queens, or, The Death of Alexander the Great. London : Printed by J. Gain, for Richard Bentley, 1684.

Lonsdale, Roger, ed. Eighteenth-Century Women Poets. Oxford: Oxford UP, 1989. Looser, Devoney. "Scolding Lady Mary Wortley Montague? The Problematics of Sisterhood in Feminist Criticism." Feminist Nightmares, Women at Odds: Feminism and the Problem of Sisterhood. Eds. Susan Ostrov Weisser and Jennifer Fleischman. New York: New York UP, 1994. 44-61.

MacLean, Gerald, and Donna Landry. Materialist Feminisms. Cambridge: Blackwell UP, 1993.

McClain, Linda C. "Equality, Oppression, and Abortion: Women Who Oppose Abortion Rights in the Name of Feminism." Feminist Nightmares, Women at Odds: Feminism and the Problem of Sisterhood. Eds. Susan Ostrov Weisser and Jennifer Fleischner. New York: New York UP, 1994. 159-88.

McDowell, Paula. The Women of Grub Street: Press, Politics, and Gender in the London Literary Marketplace, 1678-1730. Oxford: Clarendon, 1998.

McKeon, Michael. The Origins of the English Novel, 1600-1740. Baltimore: Johns Hopkins UP, 1987.

Manley, Delarivier. The New Atalantis. 1709. Introd. Ros Ballaster. New York: Penguin, 1992. 
Mason, Nicholas. "Class, Gender and Domesticity in Maria Edgeworth's Belinda." The Eighteenth-Century Novel 1.1 (2001): 271-85.

Mathias, Thomas. Pursuits of Literature. London, 1794.

Mellor, Anne. Romanticism \& Gender. New York: Routledge, 1993.

Mellor, Anne, and Richard Matlack. British Literature, 1700-1830. New York: Harcourt, 1996.

Myers, Sylvia Harcstark. The Bluestocking Circle: Women, Friendship and the Life of the Mind in Eighteenth-Century England. Oxford: Clarendon P, 1990.

Michie, Helena. Sororophobia: Differences Among Women in Literature and Culture. Oxford: Oxford UP, 1992.

Middleton, Thomas. Women Beware Women. 1613/14. Introd. Richard Dunton. Women Beware Women, and Other Plays. Oxford: Oxford UP, 1999.

Miner, Valerie. "Rumors from the Cauldron: Competition among Feminist Writers." Competition: A Feminist Taboo? Eds. Valerie Miner and Helen E. Longino. New York: The Feminist P, 1987.

Moglen, Helen. The Trauma of Gender: A Feminist Theory of the English Novel. Berkeley: U of California P, 2001.

Moore, Lisa. Dangerous Intimacies: Toward a Sapphic History of the British Novel. Durham: Duke UP, 1997.

More, Hannah. Strictures on the Modern System of Female Education, with a view of the principles and conduct prevalent among women of rank and fortune . 1813. Women Romantics 1785-1832 Writing in Prose. Ed. Jennifer Breen. London: Everyman, 1996. 106-115.

Mudge, Bradford K. The Whore's Story: Women, Pornography, and the British Novel 1684-1830. Oxford: Oxford UP, 2000.

Myers, Mitzi. "My art belongs to Daddy? Thomas Day, Maria Edgeworth, and the Pre Texts of Belinda: Women Writers and Patriarchal Authority." Revising Women: Eighteenth Century “Women's Fiction” and Social Engagement. Ed. Paula Backscheider. Baltimore: Johns Hopkins UP, 2001.

Nussbaum, Felicity. The Brink of All We Hate English Satires on Women 1660-1750. Lexington: UP of Kentucky, 1984. 
---. 'Feminotopias: The Pleasures of 'Deformity' in Mid-EighteenthCentury England." The Body and Physical Difference. Eds. David T. Mitchell and Sharon L. Snyder. Ann Arbor: U of Michigan P, 1997. 161-73.

O’Driscoll, Sally. "Lesbian Criticism and Feminist Criticism: Readings of Millenium Hall." Tulsa Studies in Women's Literature 22.1 (2003): 57-80.

Ostovich, Helen. “'Our Views Must Now Be Different': Imprisonment and Friendship in Clarissa." Modern Language Quarterly 52.2 (1991): 153-69.

Peace, Mary. "'Epicures in Rural Pleasures': Revolution, Desire and Sentimental Economy in Sarah Scott's Millenium Hall.' Women's Writing 9.2 (2002): 305-16.

Pearson, Jacqueline. Women's Reading in Britain 1750-1835: A Dangerous Recreation. Cambridge: Cambridge UP, 1999

Perry, Ruth. "Clarissa's Daughters: Or, The History of Innocence Betrayed." Clarissa and Her Readers: New Essays for the Clarissa Project. Eds. Carol Houlihan Flynn and Edward Copeland. New York: AMS, 1999. 119-41.

Pogrebin, Letty Cottin. "Competing with Women." Competition: A Feminist Taboo? Eds. Valerie Miner and Helen E. Longino. New York: The Feminist Press, 1987. 11-17.

Pohl, Nicole. "'Sweet place, where virtue then did rest': The Appropriation of the Country-House Ethos in Sarah Scott's Millenium Hall." Utopian Studies 7.1 (1996): 49-59.

Poovey, Mary. The Proper Lady and the Woman Writer: Ideology as Style in the Works of Mary Wollstonecraft, Mary Shelley, and Jane Austen. Chicago: U of Chicago P, 1984.

Powhele, Richard. “The Unsex'd Females.” 1798. British Literature, 1780-1830. Eds. Anne K. Mellor and Richard E. Matlack. New York: Hartcourt Brace, 1996: 42-43.

Price, Martin. "The Divided Heart.” Samuel Richardson. Ed. Harold Bloom. New York: Chelsea House, 1987. 33-42. 
Richard, Jessica Anne . Arts of Play: The Gambling Culture of Eighteenth-Century Britain. Dissertation Abstracts International, Section A: The Humanities and Social Sciences 63.2 (2002): 606+.

"Richardson, Samuel." Cambridge History of English and American Literature. Vol.

10. Eds. A.W. Ward and A.R. Waller. Bartleby.Com. 2005. 14 Apr. 2005.

<www.Bartleby.com/220>.

Richardson, Samuel. Clarissa, or the History of a Young Lady. 1747-8. Introd. Angus

Ross. London: Penguin, 1985.

---. Sir Charles Grandison. London, 1753-4.

The Rival Mother. London : printed for R. Baldwin, near the Oxford-Arms-Inn in Warwick-Lane, 1692.

The Rival Princesses, or, The Colchian Court. London : Printed for R. Bentley ..., 1689.

Rogers, Kay. "Deflation of Male Pretensions in Fanny Burney’s Cecilia." Women's Studies 15.1-3 (1988): 87-96.

Rosenberg, Jordana. “The Bosom of the Bourgeoisie: Edgeworth's Belinda." ELH 70.2 (2003): 575-96.

Rowlandson, Mary. The Sovereignty and Goodness of God, Together, with the Faithfulness of his Promises Displayed Being a Narrative of the Captivity and Restauration of Mrs. Mary Rowlandson. 1682. Heath Anthology of American Literature, vol. 1. $4^{\text {th }}$ ed. Ed. Paul Lauter. New York: Houghton Mifflin, 2002. 425-56.

Rubin, Gayle. "The Traffic in Women." Toward an Anthropology of Women. Ed. Rayna Reiter. New York: Monthly Review, 1975.

Russell, Gillian. "Faro's Daughters: Female Gamesters, Politics, and the Discourse of Finance in 1790's Britain.” Eighteenth-Century Studies 33.4 (2000): 481-504.

Schor, Hilary M. "Notes of a Libertine Daughter: Clarissa, Feminism, and The Rise of the Novel." Stanford Humanities Review 8.1 (2000): 94-117.

Schrift, Alan D. The Logic of the Gift: Toward an Ethic of Generosity. New York: Routledge, 1997.

Scott, Sarah. The History of Sir George Ellison. London, 1766.

---. Millenium Hall. 1962. Ed. Gary Kelly. Orchard Park: Broadview, 1995. 
Simpson, Antony. 'The Mouth of Strange Women is a Deep Pit': Male Guilt and Legal Attitudes Toward Prostitution in Georgian London." Journal of Criminal Justice and Popular Culture 4.3 (1996): 50-79.

Smith, Johanna. "Philanthropic Community in Millenium Hall and The York Ladies' Committee." The Eighteenth Century 36.5 (1995): 266-82.

Sobba Green, Katharine. The Courtship Novel, 1740-1820: A Feminized Genre. Lexington: UP Kentucky, 1991.

Sommers, Christina Hoff. Who Stole Feminism? How Women Have Betrayed Women. New York: Touchstone, 1994.

Spacks, Patricia Meyer. Gossip. Chicago: U of Chicago P, 1986.

Spencer, Jane. The Rise of the Woman Novelist: From Aphra Behn to Jane Austen. New York: Basil Blackwell, 1986.

Spender, Dale. Living by the Pen. New York: Teachers College, 1992.

Straub, Kristina. Divided Fictions: Fanny Burney and Feminine Strategy. Lexington: UP Kentucky, 1987.

Thompson, James. Models of Value: Eighteenth-Century Political Economy and the Novel. Durham: Duke UP, 1996.

Todd, Janet. The Sign of Angellica: Women, Writing and Fiction, 1660-1800. New York: Columbia UP, 1989.

---. Women's Friendship in Literature. New York: Columbia UP, 1980.

Ulanov, Ann, and Barry Ulanov. Cinderella and her Sisters: The Envied and the Envying. Philadelphia: Westminster Press, 2000.

Wahl, Susan. Invisible Relations: Representations of Female Intimacy in the Age of Enlightenment. Stanford: Stanford UP, 1999.

Wallace, Diana. Sisters and Rivals in British Women's Fiction, 1913-39. London: Macmillan, 2000.

Wallis, Claudia, et. al. "The Case for Staying Home.” Time 23 Mar. 2004: 50+. Academic Elite. Ebscohost. West Virginia University Library, Morgantown. 22 Feb. 2005. <http://search.epnet.com/login.aspx?direct=true\&db=afh\&an=12530931>. 
Warner, Judith. "Mommy Madness.” Newsweek 21 Feb. 2005: 42+. Academic Elite.

Ebscohost. West Virginia University Library, Morgantown. 22 Feb. 2005.

<http:// http://search.epnet.com/login.aspx?direct=true\&db=afh\&an=16075047>.

Watt, Ian. The Rise of the Novel: Studies in Defoe, Richardson, and Fielding. Berkeley: U of California P, 1957.

Weisser, Susan Ostrov. "The Wonderful-Terrible Bitch Figure in Harlequin Romances." Feminist Nightmares, Women at Odds: Feminism and the Problem of Sisterhood. Eds. Susan Ostrov Weisser and Jennifer Fleishchner. New York: New York UP, 1994. 269-82.

Weisser, Susan Ostrov, and Jennifer Fleischner, eds.. Feminist Nightmares, Women at Odds: Feminism and the Problem of Sisterhood. New York: New York UP, 1994.

Winner, Anthony. "Richardson's Lovelace: Character and Prediction." Samuel Richardson. Ed. Harold Bloom. New York: Chelsea House, 1987. 43-50.

Wisdom in Miniature. Worcester: Press of Isaiah Thomas, 1795.

Wollstonecraft, Mary. Vindication of the Rights of Woman. Ed. Miriam Brody London: Penguin, 1992.

Woman Not Inferior to Man: or, A short and modest Vindication of the natural Right of the Fair-Sex to a perfect Equality of Power, Dignity, and Esteem, with Men by Sophia, A Person of Quality. London: printed for John Hawkins, 1793.

Zizek, Slavov. The Sublime Object of Ideology. London: Verso, 1989. 


\section{Elizabeth Johnston}

Elizabeth D. Johnston

13 Brockway Pl.

Brockport, NY 14420

Email: ejohnston@monroecc.edu

\section{EDUCATION}

West Virginia University; Morgantown, WV

Doctor of Philosophy in English Literature; emphasis: $18^{\text {th }}$ Century British Literature; Gender Studies

GPA: 4.0/4.0; Expected Graduation: August 2005

West Virginia University; Morgantown, WV

Masters Degree in English Literature; emphasis: $18^{\text {th }}$ Century British Literature; Gender Studies; Creative Writing

GPA: 4.0/4.0; Graduation: Spring 1999

New Mexico State University; Las Cruces, NM

Bachelor of Arts in English Literature; minor in Creative Writing

GPA: 3.7/4.0; Graduation: Spring 1997

\section{TEACHING EXPERIENCE}

Monroe Community College, Fall 2003-Present

Instructor, Tenure-track

- College Composition

- Advanced College Composition

- Introduction to Literature

- Women in Literature

- American Literature to 1865

Indiana University of Pennsylvania, Fall 2001 -Spring 2003

Visiting Instructor, full-time

- College Composition 1

- College Composition 2 (Research Writing)

- Introduction to Literature

West Virginia University, Fall 1997-Summer 2001

Graduate Teaching Assistant

- Summer Transitory Entry Program (Developmental Writing)

- College Composition 1

- College Composition 2 (Research Writing)

- Business Writing

- Popular Culture 


\section{OTHER}

- Editorial/Research Assistant for The Eighteenth-Century: Theory and Interpretation, Ed. Robert Markley, Summer 2001; 1999-2000

- TA Mentor, WVU Center for Writing Excellence, Fall 2000

- Lecturer, "Women Writers," West Virginia Senior Citizen Seminar, Summer 2000

\section{SERVICE}

- MCC Basic Communications Assessment Team, 2005-present

- MCC-AAWCC Programming Committee, 2005-present

- MCC Awards Committee, 2005

- MCC Childcare Advisory Committee, 2004-2005

- MCC English 105 Assessment Committee, Summer 2004

- IUP Liberal Studies Committee, 2001-2003

- IUP Liberal Studies Sub-Committee, "Assessment of English 101 Goals/Outcomes," 2001-2003

- Judge, WVU John Scott Nelson Expository Writing Contest, Spring 2001

- Volunteer, Woodburn Elementary School, Spring 2001

- President, WVU English Graduate Organization, 2000-2001

- Treasurer, WVU English Graduate Organization, 1999-2000

- Recruitment Committee, WVU English Dept., Fall 2000

- WVU Representative, $7^{\text {th }}$ Annual Spilman Symposium, Fall 2000

- WVU Graduate Colloquium Committee, 1999

- WVU English 1 Placement Committee, 1998-1999

- Participant, Virginia Butts Sturm Resident Writers Workshop, Fall 1998

- WVU English 1 Assessment Committee, 1997-1998

\section{PROFESSIONAL ORGANIZATIONS}

- MLA

- British Women Writer's Society

- Popular Culture Association

\section{AWARDS/FELLOWSHIPS}

- English/Philosophy Adjunct Teaching Award, Monroe Community College, 2004

- Jackson Dissertational Fellowship, 2003-2004

- "Excellence in Service Award," WVU English Dept., Spring 2001

- Stephen F. Crocker Scholarship, Fall 1997- Summer 2001

- John C. and Mildred W. Ludlum Doctoral Fellowship, Fall 2000

\section{PUBLICATIONS}

- "Elizabeth Barrett Browning's Textual Bodies and the Rhetoric of Gender in $19^{\text {th }}$ Century Critical Discourse." Thirdspace 4.1 (2004) <http://www.thirdspace.ca/vol4/4_1_Johnston.htm>. 
- Review Material for The Informed Argument, 6th ed. Eds. Robert K. Miller and Robert P. Yagelski. Boston: Heinle, 2002

- Selections of WVU Guide to Academic Writing, 9th ed. Morgantown: WVU Press, 2001

\section{ACADEMIC CONFERENCES}

- "Elizabeth Barrett Browning's Textual Bodies and the Rhetoric of Gender in $19^{\text {th }}$ Century Critical Discourse," British Women Writers Conference, April 2005

- "How Women Really Are: Disturbing Parallels between Eighteenth-Century Domestic Fiction and Reality Television," Popular Culture Association, March 2005

- '"The Misery of Domestic Contention': Rivalry and Revision in Frances Burney's Cecilia (1782)," British Women Writers Conference, March 2004

- "'The Remote Cause of My Love': Female Rivalry, Nationalism, and the Threat of Miscegenation in Maria Edgeworth's Belinda (1801)," South Central Eighteenth Century Studies, February 2004

- 'Zenocrate's Statue: Memory and Ritual in Christopher Marlowe's Tamburlaine," Group for Early Modern Cultural Studies, November 2002

- "Ode to the Unborn: $19^{\text {th }}$ Century Women Poets and the Discourse of Maternity," Midwestern American Society for Eighteenth-Century Studies, October 2002

- “'An ill-judged economy': Gaming, Politics, and Women's Work in Edgeworth's Belinda (1801)," Group for Early Modern Cultural Studies, November 2001

- "Deformed, Disabled, and Dangerously Disheveled: The Rhetoric of Gender in $19^{\text {th }}$ Century Critical Discourse," WVU-CMU Colloquium, March 2001

- "A Two-Headed Monster: Sadomasochism and the Specularity of the Male Body in Fight Club," WVU-CMU Colloquium, March 2000

- "Monstrous Misconceptions: A Psychoanalytic Reading of $18^{\text {th }}$ Century Poetry Written by Women To Their Unborn Children," WVU Colloquium, 1999

\section{PROFESSIONAL DEVELOPMENT}

- Microsoft Excel Gradebook, Monroe Community College, June 2005

- Website Development, Monroe Community College, December 2004

- PowerPoint Levels 1: Creating a Presentation, Monroe Community College, December 2003

- PowerPoint Level 3: Animating Presentations, Monroe Community College, December 2003

Outlook Specialization: Web Access, Monroe Community College, September 2003 